PNL-4530

Vol. 1 of 2

UC-70

\title{
A Systems Study of the Feasibility of High-Level Nuclear Waste Fractionation for Thermal Stress Control in a Geologic Repository
}

Main Report
R. W. McKee
D. J. Silviera
H. K. Elder
J. L. Swanson
R. F. McCallum
L. E. Wiles

June 1983

Prepared for the U.S. Department of Energy under Contract DE-AC06-76RLO 1830

Pacific Northwest Laboratory Operated for the U.S. Department of Energy by Battelle Memorial Institute 


\title{
DISCLAIMER
}

This report was prepared as an account of work sponsored by an agency of the United States Government. Neither the United States Government nor any agency thereof, nor any of their employees, makes any warranty, express or implied, or assumes any legal liability or responsibility for the accuracy, completeness, or usefulness of any information, apparatus, product, or process disclosed, or represents that its use would not infringe privately owned rights. Reference herein to any specific commercial product, process, or service by trade name, trademark, manufacturer, or otherwise, does not necessarily constitute or imply its endorsement, recommendation, or favoring by the United States Government or any agency thereof. The views and opinions of authors expressed herein do not necessarily state or reflect those of the United States Government or any agency thereof.

\author{
PACIFIC NORTHWEST LABORATORY \\ operated by \\ BATTELLE \\ for the \\ UNITED STATES DEPARTMENT OF ENERGY \\ under Contract DE-AC06-76RLO 1830
}

\begin{tabular}{|c|c|}
\hline \multicolumn{2}{|c|}{$\begin{array}{c}\text { National Technical Information Service } \\
\text { United States Department of Commerce } \\
5285 \text { Port Royal Road } \\
\text { Springfield, Virginia } 22161\end{array}$} \\
\hline \multicolumn{2}{|c|}{$\begin{array}{l}\text { NTIS Price Codes } \\
\text { Microfiche A01 }\end{array}$} \\
\hline \multicolumn{2}{|c|}{ Printed Copy } \\
\hline Pages & $\begin{array}{l}\text { Price } \\
\text { Codes }\end{array}$ \\
\hline $001-025$ & $\mathrm{~A} 02$ \\
\hline $026-050$ & $\mathrm{~A} 03$ \\
\hline $051-075$ & $\mathrm{~A} 04$ \\
\hline 076.100 & A05 \\
\hline $101-125$ & $A 06$ \\
\hline $126-150$ & $\mathrm{~A} 07$ \\
\hline $151-175$ & $\mathrm{~A} 08$ \\
\hline $176-200$ & A09 \\
\hline $201-225$ & $\mathrm{~A} 010$ \\
\hline $226 \cdot 250$ & A 011 \\
\hline $251-275$ & $\mathrm{~A} 012$ \\
\hline $276-300$ & A 013 \\
\hline
\end{tabular}




\section{A SYSTEMS STUDY OF THE FEASIBILITY OF HIGH-LEVEL NUCLEAR WASTE FRACTIONATION FOR THERMAL STRESS CONTROL IN A GEOLOGIC REPOSITORY \\ MAIN REPORT
R. W. McKee
D. J. Silviera
H. K. Elder
J. L. Swanson
R. F. McCallum
L. E. Wiles

June 1983

Prepared for

the U.S. Department of Energy

under Contract DE-AC06-76RLO 1830

Pacific Northwest Laboratory

Richland, Washington 99352 


\section{ABSTRACT}

This study assesses the benefits and costs of fractionating the cesium and strontium ( $\mathrm{CS} / \mathrm{Sr}$ ) components in commercial high-level waste (HLW) to a separate waste stream for the purpose of reducing geologic repository thermal stresses in the region of the HLW.

System costs are developed for a broad range of conditions comparing the $\mathrm{Cs} / \mathrm{Sr}$ fractionation concept with disposal of 10-year-old vitrified HLW and vitrified HLW aged to achieve (through decay) the same heat output as the fractionated high-level waste (FHLW). All comparisons are based on a 50,000 metric ton equivalent (MTE) system. The FHLW and the Cs/Sr waste are both disposed of as vitrified waste but emplaced in separate areas of a basalt repository. The FHLW is emplaced in high-integrity packages at relatively high waste loading but low heat loading, while the Cs/Sr waste is emplaced in minimum-integrity packages at relatively high heat loading in a separate region of the repository. System cost comparisons are based on minimum cost combinations of canister diameter, waste concentration, and canister spacing in a basalt repository. The effects on both long- and near-term safety considerations are also addressed.

The major conclusion is that the Cs/Sr fractionation concept offers the prospect of a substantial total system cost advantage for HLW disposal if reduced HLW package temperatures in a basalt repository are desired. However, there is no cost advantage if currently designated maximum design temperatures are acceptable. Aging the HLW for 50 to 100 years can accomplish similar results at equivalent or lower costs. 



\section{ACKNOWL EDGMENTS}

Several people, in addition to the authors, made substantial contributions to this study. The authors would like to acknowledge their appreciation to L. A. Bray for his assistance in proving out with laboratory experiments the feasibility of the cesium and strontium sorption flowsheet; to G. B. Mellinger and $H$. H. Hollis for their work in establishing the feasibility and composition limits of a borosilicate waste form for the fractionated cesium/strontium waste component; to L. L. Clark and R. G. Rau for their assistance in using the RECON computer code to develop the geologic repository cost estimates; to D. E. Larson for developing the fractionation process cost estimate and the scaling relationships for the vitrification cost estimates; and to $P$. M. Daling for developing the high-level waste shipping cost estimates. 


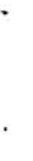


VOLUME 1 (CHAPTERS)

1.0 - INTRODUCTION

2.0 - SUMMARY AND CONCLUSIONS

3.0 - THERMAL ANALYSIS

4.0 - FRACTIONATION PROCESS DEVELOPMENT

$5.0-$ COST ANALYSIS

6.0 - RADIATION RISK ANALYSIS

7.0 - REFERENCES

VOLUME 2 (APPENDICES)

A - THERMAL ANALYSIS SUPPLEMENT

B - FRACTIONATION PROCESS EXPER IMENTAL RESULTS SUPPLEMENT

C - COST ANALYSIS SUPPLEMENT

D - RADIOLOGICAL RISK ANALYSIS SUPPLEMENT 



\section{CONTENTS}

\section{ABSTRACT}

ACKNOWLEDGMENTS

REPORT CONTENTS OUTLINE

1.0 INTRODUCTION

1.1 STUDY SCOPE AND ORGANIZATION

1.2 REPOSITORY CONCEPT

1.3 ALTERNATIVE REPOSITORY CONCEPTS •

1.4 HIGH-LEVEL WASTE CHARACTERISTICS. $\quad$ • $\quad$ • $\quad$ • $\quad$ • $\quad 1.8$

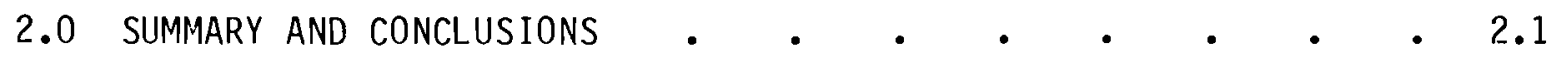

2.1 RESULTS WITH BENTONITE BACKFILL • • • • • • • 2.3

2.2 RESULTS WITHOUT BENTONITE BACKFILL $\quad$ • $\quad$ •

2.3 RADIOLOGICAL RISK CONSIDERATIONS. • • • • • • 2.6

2.4 ALTERNATIVE REPOSITORY CONCEPTS • • • • • • 2.7

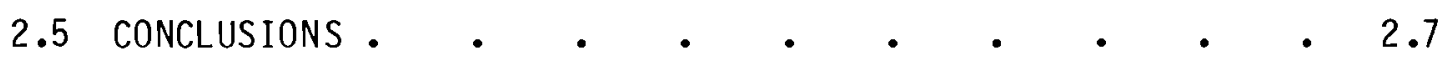

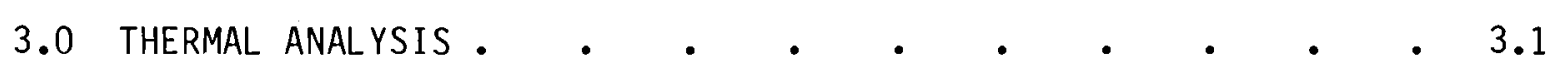

3.1 ANALYSIS BASIS AND PROCEDURE. • . • • • • • 3.3

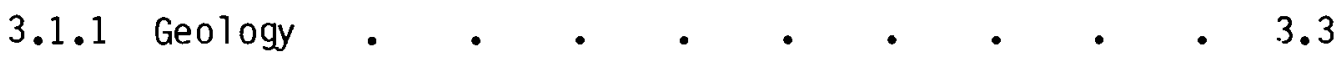

3.1 .2 Heat Decay Curves . • • • • • • • 3.4

3.1.3 Thermal Constraints . . . . . . . 3.4

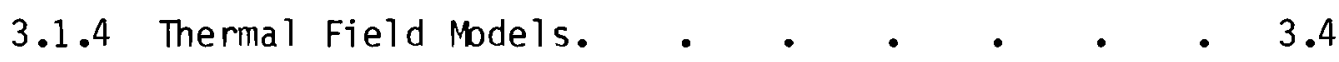

3.1 .5 Heat Transfer Code $\quad$ • $\quad$ • $\quad$ • $\quad$ • $\quad$ • 3.7

3.1 .6 Parametric Analysis . . . . . . 3.7

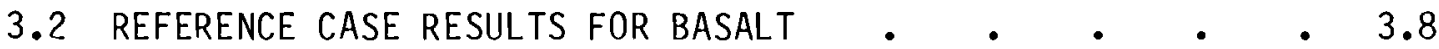

3.3 PARAMETRIC ANALYSIS RESULTS FOR BASALT • • • • • 3.10

3.4 REFERENCE CASE RESULTS FOR SALT • • • • • • • 3.21 
3.5 ALTERNATIVE WASTE EMPLACEMENT IN HORIZONTAL BOREHOLES • 3.23

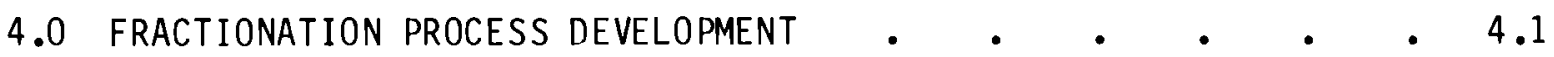

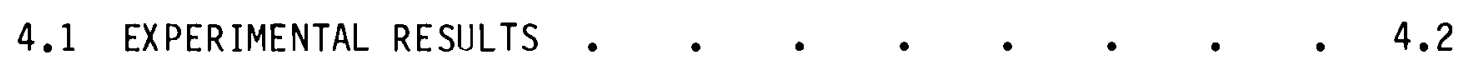

4.1.1 Preparation of Simulated High-Level Liquid Waste $\quad 4.2$

4.1.2 Sorption of Cesium on Titanium Phosphate. . $\quad 4.2$

4.1.3 Sorption of Strontium on Antimony Pentoxide . . 4.3

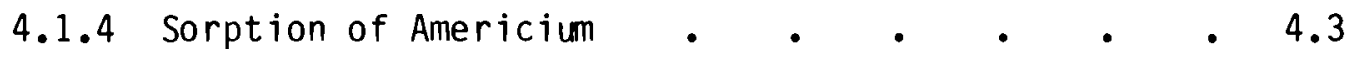

4.1.5 Sorption of Fission Products Other Than
Cesium and Strontium. $. . \quad . \quad$. 4.4

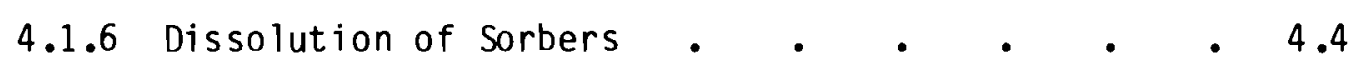

4.1.7 Vitrification of Cesium- and Strontium-
Loaded Sorbers $\quad$ - . . . . . . 4.5

4.2 REVISED FRACTIONATION FLOWSHEET • • • • • • • • • 4.6

4.3 OTHER FLOWSHEET CONSIDERATIONS • • • • • • • 4.11

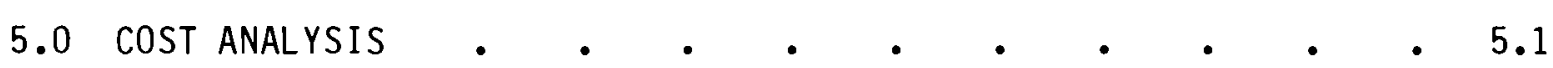

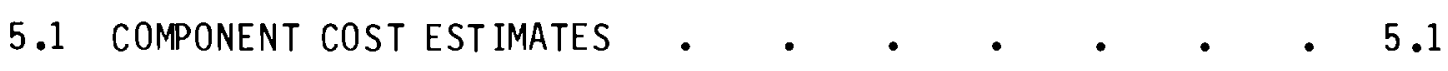

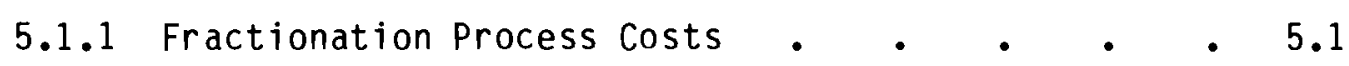

5.1.2 Waste Vitrification Process Costs . . . . 5.4

5.1.3 High-Level Waste Transportation Costs . $\quad$ • 5.8

5.1.4 Long-Term Storage Costs for HLW and Cs/Sr Waste . 5.15

5.1 .5 Geologic Repository Costs. . . . . 5.16

5.2 SYSTEM COST ANALYSIS $\quad$ • $\quad$ • $\quad$ • $\quad$ • 5.22

5.2 .1 Cost Analysis Methodology. $\quad$ • $\quad$ • $\quad$ • 5.23

5.2.2 Minimum Cost Comparisons with Bentonite Backfill • 5.34

5.2.3 Minimum Cost Comparisons Without Bentonite Backfill 5.55

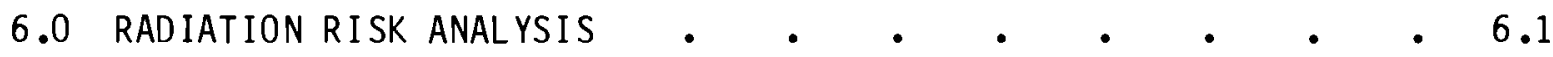

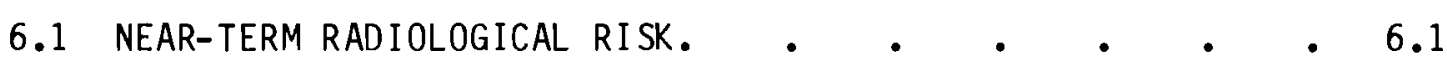


6.1.1 Population Dose for System Alternatives During

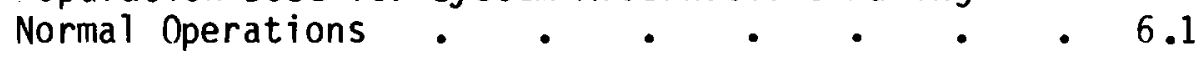

6.1.2 Radiological Impact in the Event of Accidents. $\quad 6.4$

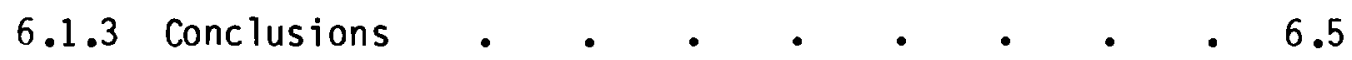

6.2 INTERIM STORAGE RADIOLOGICAL RISK $\quad$ • $\quad$ • $\quad$ • $\quad$ • $\quad 6.7$

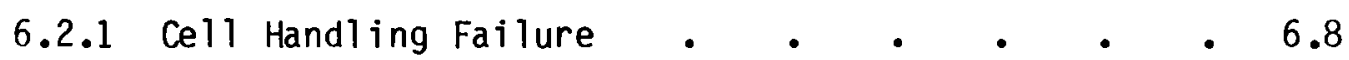

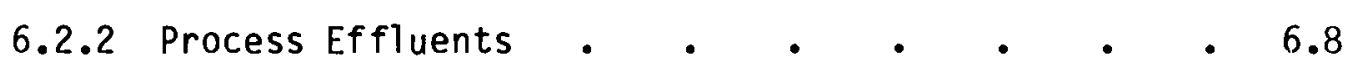

6.3 LONG-TERM RADIOLOGICAL RISK $\quad$ • $\quad$ • $\quad$ • $\quad$ • $\quad$ • 6.9

6.3.1 Radionuclide Release Mechanisms . . . 6.10

6.3.2 Application of Regulations • • • • • • 6.11

6.3.3 Natural Event Releases . • . . • • • 6.13

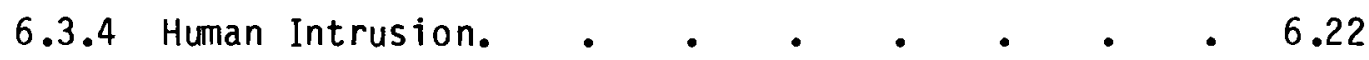

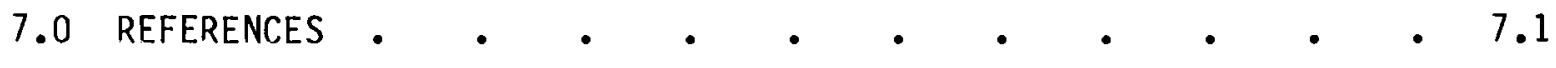


FIGURES

1.1 Three Alternatives for Evaluation of the $\mathrm{Cs} / \mathrm{Sr}$

Fractionation Concept $\quad . \quad$. $\quad . \quad . \quad . \quad$. 1.3

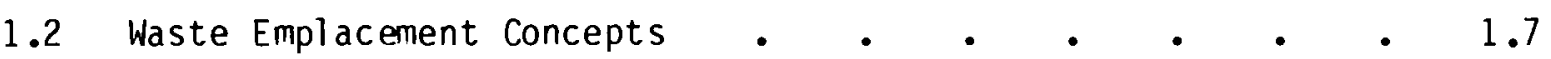

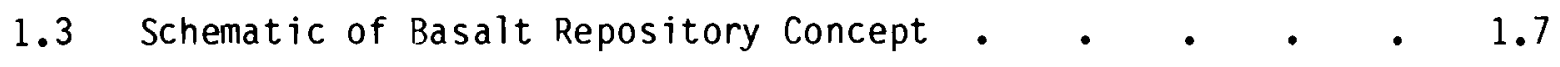

2.1 Total 50,000 MTE System Cost Comparison for HLW, Aged-HLW and FHLW Disposal with Bentonite Backfill. • . 2.3

2.2 Total 50,000 MTE System Cost Comparison for HLW and

FHLW Disposal Without Bentonite Backfill..$\quad$ • . 2.6

3.1 Thermal Loading Design Envelope for 0.5-Foot-Diameter

$\mathrm{HLW} / \mathrm{FHLW} /$ Aged-HLW Canisters . $\quad . \quad$ • . . . . 3.14

3.2 Thermal Loading Design Envelope for 1.0-Foot-Diameter

HLW/FHLW/Aged-HLW Canisters . • • • • . . 3.15

3.3 Thermal Loading Design Envelope for 1.7-Foot-Diameter

HLW/FHLW/Aged-HLW Canisters . • • • • • • 3.16

3.4 Thermal Loading Design Envelope for 2.5-Foot-Diameter

HLW/FHLW/Aged-HLW Canisters . • • • • • • 3.17

3.5 Thermal Loading Design Envelope for 1.0-Foot-Diameter

$\mathrm{Cs} / \mathrm{Sr}$ Canisters. $\quad . \quad . \quad . \quad . \quad . \quad . \quad$. 3.18

3.6 Thermal Loading Design Envelope for 1.7-Foot-Diameter

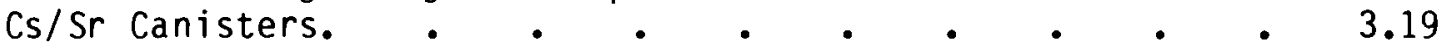

3.7 Thermal Loading Design Envelope for 2.5-Foot-Diameter

$\mathrm{Cs} / \mathrm{Sr}$ Canisters. $\quad . \quad$. $\quad . \quad . \quad . \quad . \quad$. 3.20

4.1 Revised Cs/Sr Fractionation Flowsheet $\quad$. $\quad . \quad$ e $\quad$ • $\quad 4.8$

5.1 Fractionation Process Equipment Flow Diagram • • • • 5.2

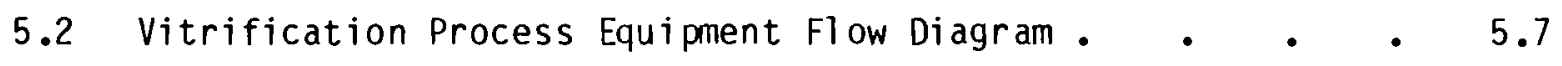

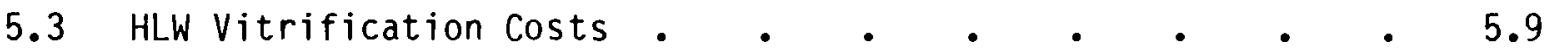

5.4 FHLW and Cs/Sr Vitrification Costs . . . . . 5.10

5.5 Rail Transport Costs for HLW, FHLW and Cs/Sr Waste..$\quad$. 5.14

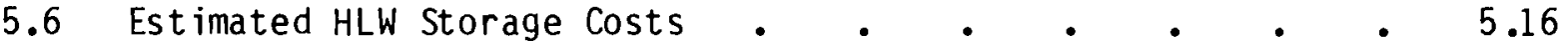

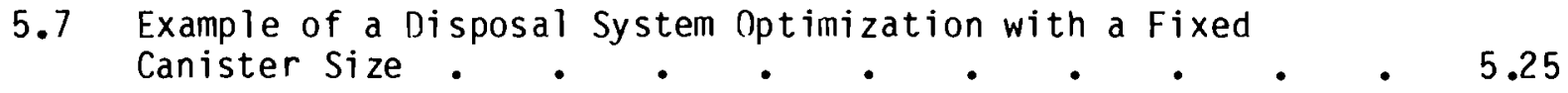


5.8 Example Showing Declining System Costs as Canister Size is Reduced. $. . . \quad . \quad . \quad . \quad . \quad 5.26$

5.9 Minimum Total System Costs for HLW Over a Range of Canister Sizes and Maximum Bentonite Temperatures . . . 5.28

5.10 Minimum Total System Costs for FHLW Recycle Case Over a Range of Canister Sizes and Maximum Bentonite Temperatures

5.11 Minimum Total System Costs for FHLW No-Recycle Case Over a Range of Canister Sizes and Maximum Bentonite Temperatures

5.12 Minimum Total System Costs for Aged-HLW Over a Range of Canister Sizes and Maximum Bentonite Temperatures

5.13 Minimum Total System Costs for Cs/Sr Waste $\quad$ • $\quad$ • 5.32

5.14 Opt imum Canister Heat Loading Determination for HLW $• \quad$ • 5.33

5.15 Optimum Canister Heat Loading Determination for FHLW

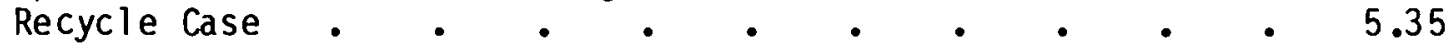

5.16 Optimum Canister Heat Loading Determination for FHLW

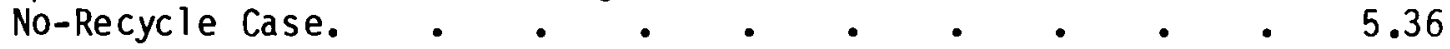

5.17 Optimum Canister Heat Loading Determination for Aged-HLW $. \quad . \quad . \quad . \quad . \quad . \quad 5.37$

5.18 Optimum Canister Heat Loading Determination for

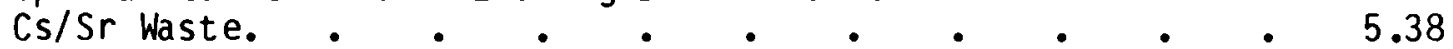

5.19 Total 50,000 MTE System Cost Comparison for HLW, Aged-HLW, and Fractionated HLW Disposal with Bentonite Backfill . . . . . . . . . 5.40

5.20 HLW Canister Loading Relationships for Specified Maximum Centerline Temperatures . . . . . 5.58

5.21 FHLW (recycle case) Loading Relationships for Specified Maximum Waste Centerline Temperatures . $\quad$ • 5.59

5.22 FHLW (no-recycle case) Loading Relationships for Specified Maximum Waste Centerline Temperatures

5.23 Total 50,000 MTE System Cost Comparison for HLW and Fractionated HLW Disposal Without Bentonite Backfill • $\quad 5.62$

6.1 Schematic of Exposed Repository Area . • . . . 6.22 


\section{$\underline{\text { TABLES }}$}

1.1 Cesium-137 and Strontium-90 Radioactivity Contained in 1 Metric Ton of Reference Spent Fuel . . . . . 1.4

1.2 Thermal Conductivity Comparisons . • • • • • • 1.6

1.3 Effect of Cesium and Strontium Removal on the Heat

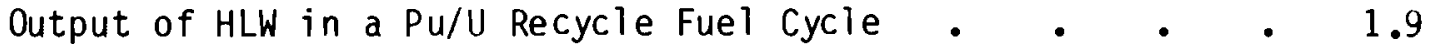

1.4 Effect of Cesium and Strontium Removal on the Heat
Output of HLW in a Once-Through Fuel Cycie • . . . 1.10

1.5 Effect of Cesium and Strontium Removal on the Gamma Energy Emission Rate. $\quad$ • . . . . . . . 1.11

2.1 50,000 MTE Repository Area Requirements for HLW and FHLW and Aged-HLW with Bentonite Backfill • • • . 2.5

2.2 50,000 MTE Repository Area Requirements for HWL and FHLW Without Bentonite Backfill • . • • . . 2.6

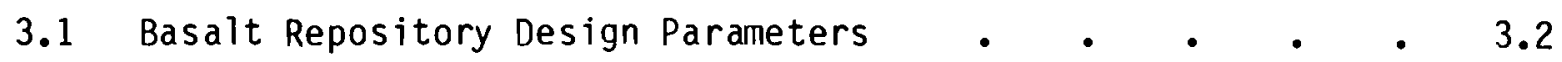

3.2 Decay Heat Data for Three Waste Types • • • • • $\quad 3.5$

3.3 Repository Temperature Limits • • • • • • • • 3.6

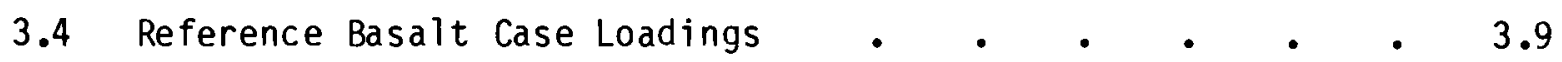

3.5 Reference Basalt Case Maximum Temperatures . $\quad$ • . 3.9

\begin{tabular}{l} 
3.6 Heat Loading Limits for HLW Canisters in Basalt with \\
Bentonite Backfill \\
\hline
\end{tabular}

3.7 Heat Loading Limits for CS/Sr Waste Canisters in
Basalt Without Bentonite Backfill $. \quad \bullet \quad \bullet \quad . \quad . \quad . \quad 3.13$

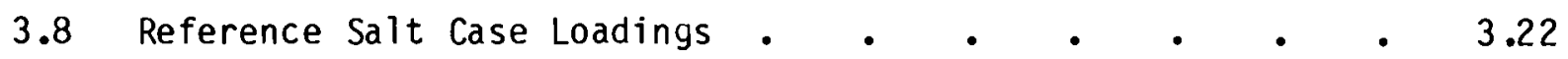

3.9 Reference Salt Case Maximum Temperatures . . . 3.22

3.10 Peak Temperatures of Waste Package Components for
Horizontal Borehole Concept . . . . . . . 3.23

5.1 Estimated Costs for a Cs/Sr Fractionation Facility $\quad$ e $\quad 5.3$

5.2 Reference HLW Canisters and Shipping Parameters • • 5.11 5.3 Transportation Costs for Rail HLW Shipments with
Various Canister Sizes and Heat Loads • • • . . . 5.13 
5.4 Input Parameters for HLW and FHLW Repository Loading Cases • 5.17

5.5 Input Parameters for CS/Sr Waste Canisters . • • 5.17

5.6 Comparison of Total System Costs for HLW, FHLW, and Aged-HLW; Disposal with Rentonite Backfill $\quad$ • $\quad$ • $\quad 5.39$

5.7 Comparison of Total Repository Area Requirements for HLW, FHLW, and Aged-HLW with Bentonite Backfill • • 5.41

5.8 Repository Emplacement Features and System Costs for

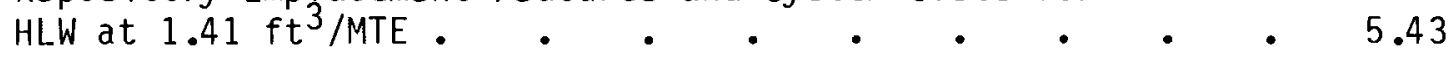

5.9 Repository Emplacement Features and System Costs for HLW at $3.14 \mathrm{ft}^{3} / \mathrm{MTE}$. $. \quad . \quad . \quad . \quad . \quad . \quad . \quad 5.44$

5.10 Repository Emplącement Features and System Costs for FHLW at $1.20 \mathrm{ft}^{3} / \mathrm{MTE}$. $\quad . \quad . \quad . \quad . \quad . \quad . \quad . \quad 5.45$

5.11 Combined Area Requirements and System Cost for FHLW at
$1.20 \mathrm{ft}^{3} / \mathrm{MTE}$ with Cs/Sr Waste in the Same Repository

5.12 Repository Emplacement Features and System Costs for

5.13 Repository Emplącement Features and System Costs for

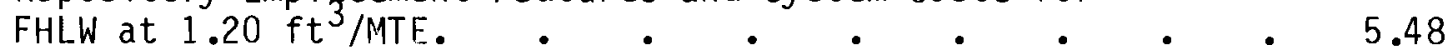

5.14 Combined Area Requirements and System Costs for FHLW at
$1.20 \mathrm{ft}^{3} / \mathrm{MTE}$ with Cs/Sr Waste in the Same Repository * $\quad 5.49$

\begin{tabular}{l}
5.15 Repository Emplącement Features and System Costs for \\
FHLW at $2.70 \mathrm{ft} / \mathrm{MTE}$. \\
\hline
\end{tabular}

5.16 Repository Emplacement Features and System Costs for

5.17 Repository Emplacement Features and System Costs for
Aged-HLW at $3.14 \mathrm{ft}^{3}$ MTE . • • • • • 5.52

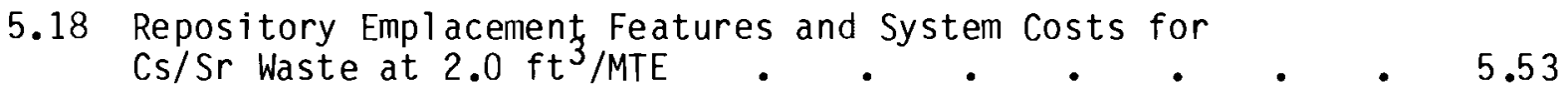

5.19 Repository Emplacement Features and System Costs for
Cs/Sr Waste at $1.73 \mathrm{ft}^{3} / \mathrm{MTE}$

5.20 Comparison of Repository Emplacement Features and System Costs for 10-year-oia is/Sr Waste with 60-Year-Aged Cs/Sr Waste at $1.73 \mathrm{ft}^{3} /$ MTE with a $300^{\circ} \mathrm{C}$ Maximum Basalt Temperature $\quad 5.56$

5.21 Comparison of Total System Costs for HLW and FHLW Disposal Without Bentonite Backfill $\quad$ • $\quad$ • $\quad$ • 5.61 
5.22 Comparison of Total Repository Area Requirements

for HLW and FHLW Without Bentonite Backfill Requirements $\quad 5.63$

5.23 Repository Emplacement Features and System Costs

for HLW at $1.41 \mathrm{ft}^{3} /$ MTE Without Bentonite Backfill. $\quad$ • 5.64

5.24 Repository Emplacement Features and System Costs for

HLW at $3.14 \mathrm{ft}^{3} /$ MTE Without Bentonite Backfill • • 5.64

5.25 Repository Emplacement Features and System Costs

for FHLW at $1.20 \mathrm{ft}^{3} /$ MTE Without Bentonite Backfill . $\quad 5.65$

5.26 Repository Emplacement Features and System Costs

for FHLW at $2.70 \mathrm{ft}^{3} /$ MTE Without Bentonite Backfill • $\quad 5.66$

5.27 Repository ${ }_{3}$ Emplacement Features and System Costs for FHLW

at $1.20 \mathrm{ft}^{3} /$ MTE Without Bentonite Backfill $\quad$ • $\quad$ • 5.67

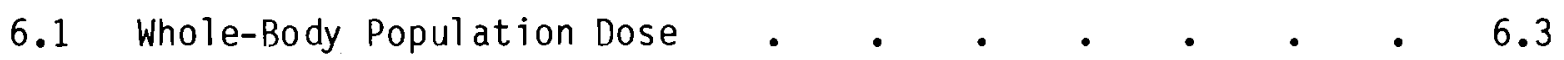

6.2 Umbrella Source-Term Accidents.

6.3 70-Year Whole-Body Dose Commitment to Maximum-

Exposed Individual . $. \quad . \quad . \quad . \quad . \quad . \quad .6 .6$

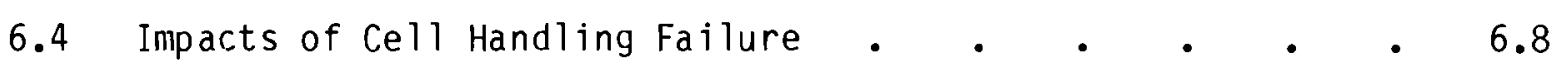

6.5 70-Year Lifetime Whole-Body Dose to Regional Population

6.6 Draft Environmental Protection Agency Cumulative Release

Limits to the Accessible Environment for 10,000 Years

After Repository Closure . . . . . . . . 6.12

6.7 Proposed Nuclear Regulatory Commission Performance Objectives. $\quad 6.12$

6.8 Radionuclide Concentration Guide Values for selected

Radionuclides in Water . $. \quad . \quad . \quad . \quad . \quad . \quad$. 6.14

6.9 Input Parameters to Faulting Event Calculation--Reference Case $\quad 6.17$

6.10 Input Parameters to Faulting Event Calculation--Alternative A $\quad 6.17$

6.11 Input Parameters to Faulting Event Calculation--Alternative B $\quad 6.17$

6.12 Cumulative Releases and Maximum Concentrations

of $241 \mathrm{Am}$ for Each Alternative and Subcase . . . 6.19

6.13 Estimated Transport Times for Radionuclides

in a Basalt Repository . . . . . . . . 6.20

6.14 Cumulative Release of $241_{\text {Am }}$ for Each Alternative and Subcase. $\quad 6.27$ 


\subsection{INTRODUCTION}

The current U.S. program for disposal of high-level waste (HLW) produced in the commercial nuclear power fuel cycle calls for disposal of this waste in repositories located deep within stable geologic formations. The HLW may be either spent fuel assemblies or the concentrated and solidified HLW from fuel reprocessing remaining after the uranium and plutonium components of the spent fuel have been recovered for reuse. Draft EPA (1982) standards allow for only very limited releases of radioactivity to the environment from waste repositories for a period of at least 10,000 years after HLW disposal. In addition to high levels of radiation, the HLW produces substantial quantities of heat for many years after disposal. The dissipation of this radiation and heat in a manner that will not disrupt the stability of either the waste containers or the geologic formation and allow transport of the radioactivity to the accessible environment by means of ground-water penetration is a major concern in developing deep geologic repository designs.

If spent fuel is reprocessed to recover the uranium and plutonium, an opportunity will be provided for additional processing to separate other HLW components to enhance the disposal integrity of the HLW. Cesium-137 and strontium-90, both with half-lives of about 30 years, and their short-lived decay products produce 70 to $90 \%$ of the HLW heat output and a larger percentage of the gamma activity of 10- to 100-year-old commercial HLW. Platt and Eschbach (1981) suggested the fractionation of the cesium and strontium from the HWL as a means to reduce the thermal stresses and gamma activity in a geologic repository. More recently, Northrup et al. (1982) discussed this concept at an IAEA symposium.

The U.S. Department of Energy (DOE) contracted with the Pacific Northwest Laboratory ( $P N L)$ to evaluate the feasibility of processing commercial HLW to fractionate the cesium and strontium components to a separate waste stream for waste management purposes. The primary objectives were to determine if fractionation could provide a means relative to other alternatives for controlling thermal stresses in a geologic repository. The primary incentive was the 
prospect of enhancing the ability to license such a repository. There is also the possibility that there are useful applications for separated cesium and strontium, but this aspect was not evaluated in this study.

Alternatives to cesium/strontium ( $\mathrm{CS} / \mathrm{Sr}$ ) fractionation that could be used to reduce thermal stress include:

1. Dispersing the HLW canisters over a larger area, at the expense of increased area and mining requirements.

2. Diluting the HLW to reduce its heat output and dispersing it over a larger area. This would increase the volume of HLW glass and the number of canisters and would also increase the area and mining requirements.

3. Using smaller canisters to limit their heat output and dispersing them over a larger area. This would increase the number of canisters, but not the waste volume, and would also increase the area and mining requirements.

4. Storing the HLW for a number of years to achieve thorough radioactive decay, a result similar to fractionation, at the expense and risks involved with the storage operations.

The fractionation concept poses the problem of disposal of the Cs/Sr waste. This waste could be stored until the heat decays to lower levels, but this has similar disadvantage to storing the entire HLW component. It might be preferable to simply store the unfractionated HLW and allow the CS/Sr component to decay in that form. If the Cs/Sr waste is sent to geologic disposal heat would be added back into the repository and there might be no net again.

After some initial investigation and evaluation, the analysis focused on the three basic alternatives illustrated in Figure 1.1. Alternative $I$ is the reference concept, in which 10-year-old (10 years from reactor discharge) HLW is vitrified and sent to a geologic repository. Alternative II is the $\mathrm{Cs} / \mathrm{Sr}$ fractionation concept, in which the HLW is separated into two components: a fractionated high-level waste (FHLW), which is vitrified and sent to geologic disposal, and the CS/Sr component, which is also vitrified and may be either stored prior to disposal to allow for decay to lower heat output levels or sent directly to a geologic respository. In Alternative III, 10-year-old HLW is 

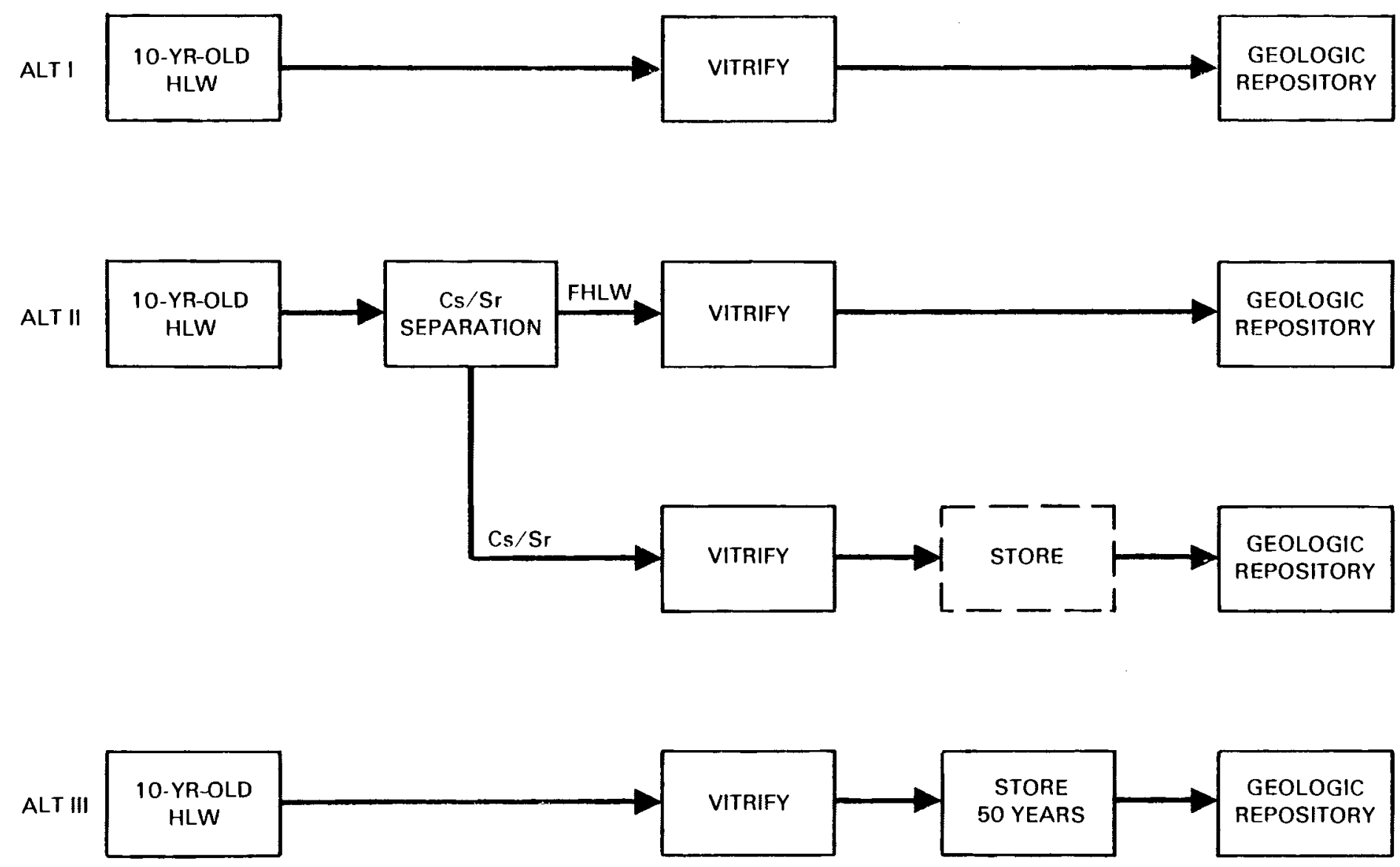

FIGURE 1.1. Three Alternatives for Evaluation of the CS/Sr Fractionation Concept 
also vitrified, but is stored in a surface monitored-retrievable-storage (MRS) facility for a period of approximately 50 years. The storage accomplishes, through decay, the same reduction in heat output as fractionation of the Cs/Sr, after which time the waste is sent to a geologic repository.

For the fractionation alternative, the FHLW component could be emplaced in canisters with a relatively low heat loading but with a high equivalent waste loading, and in high-integrity waste disposal packages for very long-term survival and containment of radionuclides. The Cs/Sr waste could be emplaced in canisters with a relatively high heat loading but with only nominal waste package integrity since, relative to the long-term containment required for the other HLW components, the radionuclides in this waste decay to negligible levels in a short period of time. Only one ten-thousandth of the initial Cs/Sr would remain after 500 years, as shown in Table 1.1. The relatively rapid decay of the radioactive cesium and strontium combined with the dilution and long time period required for any of this material to reach the biosphere (probably thousands of years for conceivable release scenarios) reduces the risk from short-lived Cs/Sr canisters to insignificant levels.

TABLE 1.1. Cesium-137 and Strontium-90 Radioactivity Contained in 1 Metric Ton of Reference Spent Fuel, Curies

\begin{tabular}{|c|c|c|c|c|c|}
\hline \multirow[b]{2}{*}{ Radionuclide } & \multicolumn{5}{|c|}{ Years Since Reactor Discharge } \\
\hline & 10 & 300 & 500 & 600 & 1000 \\
\hline${ }^{137} \mathrm{Cs}$ & $7.5 \times 10^{4}$ & 73 & 0.72 & 0.072 & $6.9 \times 10^{-6}$ \\
\hline${ }^{90} \mathrm{Sr}$ & $4.9 \times 10^{4}$ & 48 & 0.47 & 0.047 & $4.5 \times 10^{-6}$ \\
\hline
\end{tabular}

\subsection{STUDY SCOPE AND ORGANIZATION}

Four major tasks were undertaken in this study: 1) an extensive heat transfer analysis, discussed in Chapter 3 , established the basis for defining allowable waste emplacement configurations in the repository; 2) a fractionation process study, discussed in Chapter 4, analyzed the fractionation process requirements and established the feasibility of the proposed fractionation process through bench-scale laboratory experiments; 3 ) costs, discussed in Chapter 5, were developed for each of the waste management system components, including fractionation, vitrification, transportation, storage and 
disposal, and optimum system costs were developed to compare the waste management alternatives; and 4) both near- and long-term relative risks, discussed in Chapter 6, were evaluated for the processing, transportation, storage and final disposal requirements for each of the three waste types (i.e., HLW, FHLW and CS/Sr waste).

The emphasis in the thermal analysis was on temperature limits at or near the waste canisters. Previous work indicated that in a basalt repository these temperatures would be the limiting concern rather than the overall repository loading. In other words, the very-near-field thermal loadings tend to limit the far-field loadings.

For the cost analysis, alternatives were compared on a constant-dollar basis without any cost discounting considerations. Discounting was found to have little effect on the relative advantages of the near-term disposal alternatives, and the analysis is simplified. For the storage alternatives, the uncertainty in selecting an appropriate discount rate over the long time periods involved (50 plus years) was the primary consideration. It is clear, however, that in an alternative that uses long-term storage to reduce heat output rates, even a small discount rate would substantially reduce the present-worth cost of the repository component of disposal costs.

Because work on the four major tasks of this study progressed in parallel, not all of the findings in the latter stages of the study could be incorporated in all components of the analysis. For this reason, there are some small inconsistencies in some components of this report. However, these do not have a significant effect on the results or affect the validity of any of the conclusions.

In addition to the four major tasks discussed in Chapters 3 through 6 , the summary and conclusions of this study are contained in Chapter 2, and the references are 1 isted in Chapter 7 . Four appendices, published separately in Volume 2, supplement the information provided in this volume.

\subsection{REPOSITORY CONCEPT}

The analysis centered on disposal in a deep basalt formation repository. The reasons for this choice were the relatively low thermal conductivity of basalt, which constrains the dissipation of the HLW heat, and the belief that 
this would enhance the attractiveness of the fractionation concept. A further constraint on the heat dissipation in a basalt repository is the possible requirement for an absorbent material such as bentonite clay or a clay-basalt mixture as one of a series of multiple barriers designed to inhibit release of radioactivity. Bentonite or bentonite-basalt mixtures have an even lower thermal conductivity than basalt. Because of the relatively short containment period required, it was assumed in this study that the Cs/Sr canisters would not require the bentonite backfill. The thermal conductivity of possible repository media and the bentontte-basalt mixture are compared in Table 1.2.

\begin{tabular}{|c|c|}
\hline $\begin{array}{l}\text { Geologic } \\
\text { Media }\end{array}$ & $\begin{array}{l}\text { Conductivity, } \\
\mathrm{W} / \mathrm{m} \text { at } 200^{\circ} \mathrm{C} \\
\end{array}$ \\
\hline Salt & 3.0 \\
\hline Basalt & 1.5 \\
\hline Granite & 2.3 \\
\hline Shale & 1.7 \\
\hline Tuff & $1.6-2.4$ \\
\hline Bentonite/Basalt Mixture & 0.75 \\
\hline
\end{tabular}

The emplacement concept used here for the basalt repository uses vertical boreholes in a single row down the center of the emplacement rooms with one canister per bore hole. The HLW and FHLW canisters are overpacked with a longlived canister in a surface facility prior to repository emplacement. The $\mathrm{Cs} / \mathrm{Sr}$ waste canisters are overpacked in a less-expensive, shorter-lived canister. The two emplacement concepts are shown schematically in figure 1.2. To ensure stability of the formation near the shafts, a large 500-acre shaft pillar exclusion area is required. Emplacement of HLW and Cs/Sr waste on separate sides of this exclusion area provides a separation barrier between the two waste types. A higher heat flux in the $\mathrm{Cs} / \mathrm{Sr}$ emplacement area, but still within acceptable design limits, should not jeopardize the higher-integrity objective for the FHLW emplacement area. This concept is illustrated schematically in Figure 1.3. 


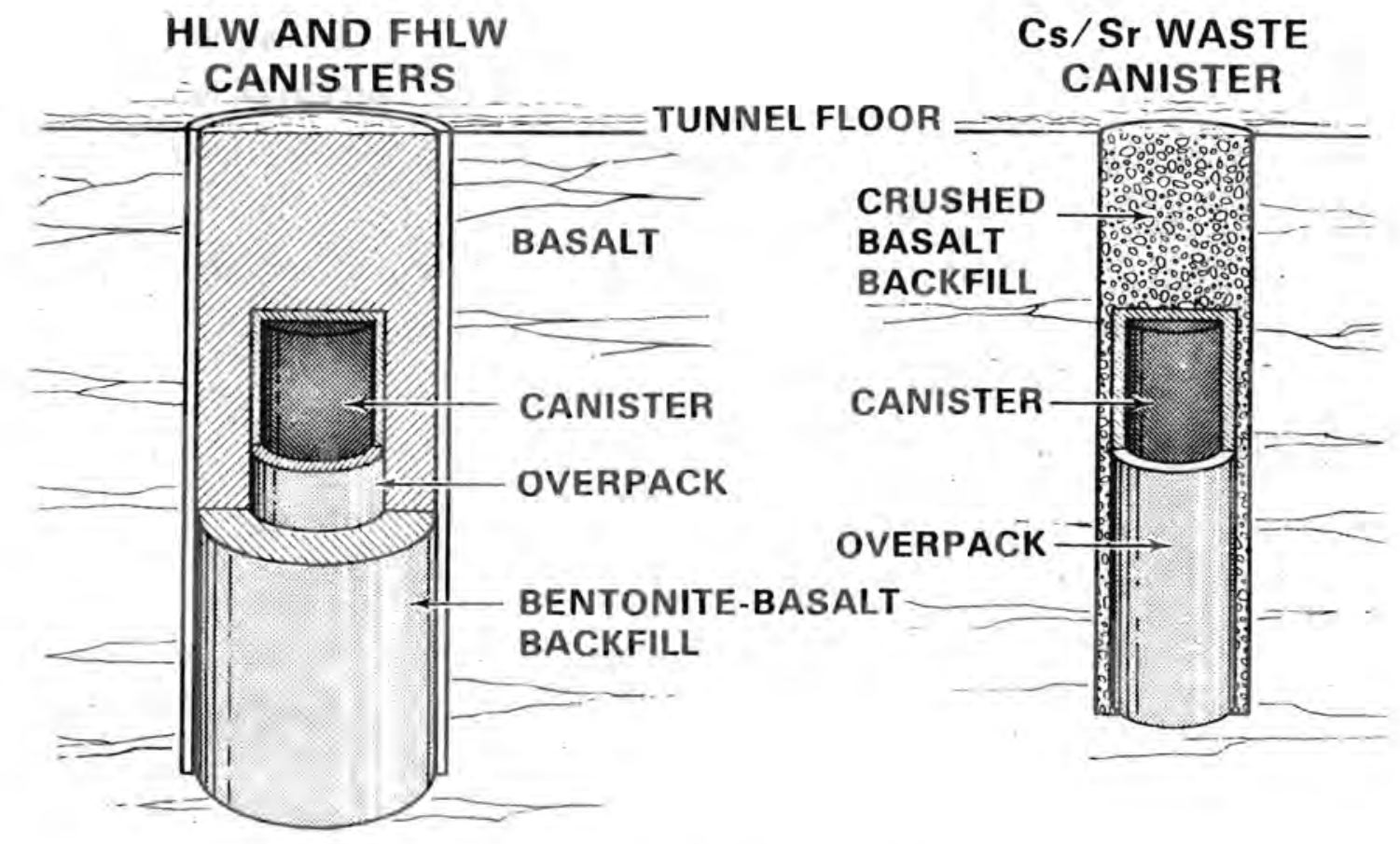

FIGURE 1.2. Waste Emplacement Concepts

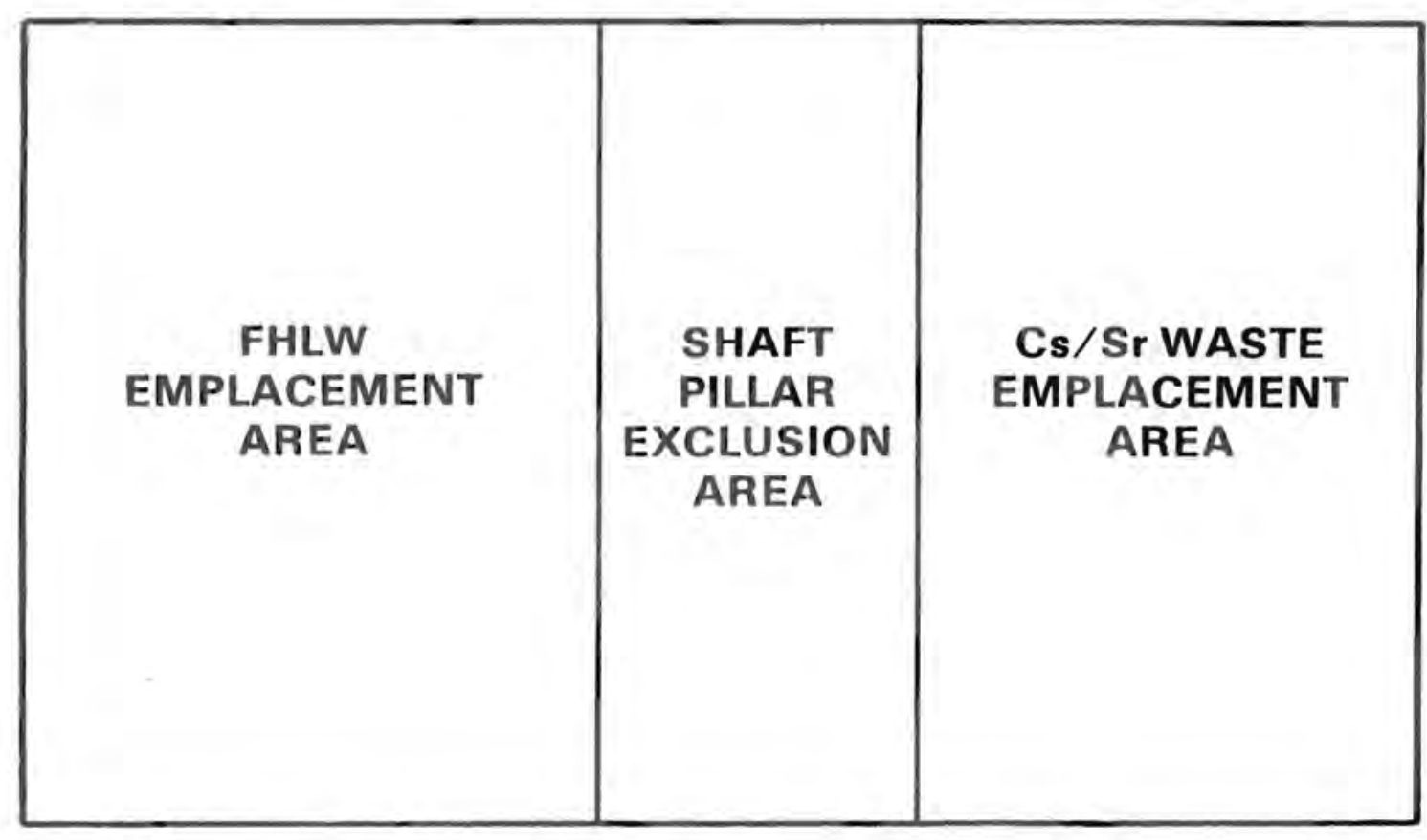

FIGURE 1.3. Schematic of Basalt Repository Concept 
No consideration was given in this analysis to the repository requirements or system costs for disposal of TRU wastes that will accompany the HLW. These were considered to be a fixed requirement in all cases. There may be small variations in quantities that result from variations in the fractionation and vitrification processes, but these are minor compared to total quantities. It was assumed in this study that the TRU requirements would not influence the relative advantages of the alternatives evaluated.

\subsection{ALTERNATIVE REPOSITORY CONCEPTS}

A more 1 imited analysis was carried out for emplacing HLW and FHLW canisters without the bentonite/basalt backfill material.

A concept for emplacing HLW canisters in horizontal boreholes drilled through the pillars separating repository rooms has currently evolved as the reference concept in the Basalt Waste Isolation Project (BWIP). Multiple canisters are placed end-to-end in each borehole, but the separation of these multiple-canister horizontal boreholes is much greater than the separation of single-canister vertical boreholes. The backfill is not added until the waste has cooled for a number of years after emplacement. For comparative purposes, a 1 imited analysis of this concept was carried out.

A 7 imited consideration was aTso given in this study to disposal of these wastes in a salt repository.

\subsection{HIGH-LEVEL WASTE CHARACTERISTICS}

Three factors, in addition to fuel exposure and power level during irradiation, affect the radioactivity and heat output of the HLW from fuel reprocessing: 1) the amount of plutonium recycle involved, which strongly affects the transuranic nuclide content; 2) the time between the reactor discharge and reprocessing, which affects the amount of americium-241 growing in from the decay of plutonium-241; and 3) the age of the waste relative to reactor discharge, which determines the remaining radioactivity.

Recognizing these factors, two HLW radionuclide compositions were considered in this analysis. One is the reference waste composition used to develop the Generic Environmental Impact Statement on Commercial Radioactive 
Waste Management (DOE 1980), which was detailed in Volume 1 of DOE (1979a). This represents an HLW composition that would evolve after a period of about 20 years of plutonium recycle. The spent fuel was processed 1-1/2 years after reactor discharge and the waste sent to disposal 10 years after discharge. The effect of cesium and strontium removal on heat output of the HLW from this plutonium/uranium recycle waste composition is shown in Table 1.3, for waste ages ranging from 10 to 100 years. The heat output of $\mathrm{FHLW}$ at both a $95 \% \mathrm{Cs} / \mathrm{Sr}$ removal and a $99 \% \mathrm{Cs} / \mathrm{Sr}$ removal is shown in this table. In this analysis, a

TABLE 1.3. Effect of Cesium and Strontium Removal on the Heat Output of HLW in a Pu/U Recycle Fuel Cycle, Watts/MTE

$$
\frac{H L W \text { Age (years) }}{10 \quad 50 \quad 60 \quad 100}
$$

$\underline{H L W}$

\begin{tabular}{lrrrr}
\hline Fission Products & 870 & 290 & 220 & 88 \\
$\begin{array}{l}\text { Actinides } \\
\text { Total }\end{array}$ & $\frac{210}{1080}$ & $\frac{66}{356}$ & $\frac{53}{273}$ & $\frac{32}{120}$
\end{tabular}

FHLW $195 \%$ CS/Sr Removed

$\begin{array}{lrrrrr}\text { Fission Products } & 93 & 22 & 19 & 6 \\ \begin{array}{c}\text { Actinides } \\ \text { Total }\end{array} & 210 & \frac{66}{303} & \frac{53}{88} & \frac{32}{72} & \frac{38}{38}\end{array}$

FHLW $(99 \%$ CS/Sr Removed)

$\begin{array}{lllll}\text { Total } & 270 & 77 & 64 & 34\end{array}$

95\% Cs/Sr removal was assumed, although the results of the process analysis now indicate that a $99 \%$ removal is feasible. As shown in Table 1.3, a waste age of about 60 years accomplishes approximately the same heat reduction as does the $\mathrm{Cs} / \mathrm{Sr}$ fractionation process for this waste.

The second waste type considered in this analysis represents the type of HLW that can be anticipated during the early years of reprocessing, when there is a large backlog of spent fuel representing once-through fuel cycle operation and the spent fuel will have been stored for a number of years prior to reprocessing. For this case, the spent fuel was stored for 10 years prior to reprocessing, with the HLW sent to disposal as it is produced. The effect of 
cesium and strontium removal on the heat output of this HLW is shown in Table 1.4. This table also shows the heat output of the FHLW at 95 and $99 \%$ $\mathrm{Cs} / \mathrm{Sr}$ removal. At 10 years of age, the heat output of this FHLW is only about $60 \%$ of the heat output of the FHLW in the recycle case. However, because of the amount of americium-241 that grows in prior to reprocessing, at 50 years of age, the heat output of this once-through-cycle FHLW is almost equal to the recycle waste. It has a higher heat output at any age greater than 60 years.

TABLE 1.4. Effect of Cesium and Strontium Removal on the Heat Output of HLW in a Once-Through Fuel Cycle, Watts/MTE

$\frac{H L W \text { Age (years) }}{10 \quad \underline{50} \quad \underline{60} \quad \underline{100}}$

$\underline{H L W}$

$\begin{array}{lrrrr}\text { Fission Products } & 927 & 318 & 250 & 96 \\ \begin{array}{l}\text { Actinides } \\ \text { Total }\end{array} & \frac{88}{1015} & \frac{61}{379} & \frac{58}{308} & \frac{51}{147}\end{array}$

FHLW (95\% Cs/Sr Removed)

$\begin{array}{lrrrrr}\text { Fission Products } & 92 & 23 & 17 & 6 \\ \begin{array}{lrrr}\text { Actinides } \\ \text { Total }\end{array} & \frac{88}{180} & & \frac{61}{84} & \frac{58}{75} & \frac{51}{57}\end{array}$

FHLW $199 \%$ CS/Sr Removed) Total $145 \quad 71 \quad 66 \quad 54$

Most of the gamma activity of the HLW, particularly for older wastes, is associated with the cesium and strontium components. The composite gamma energy emission rates for HLW and FHLW are compared in Table 1.5 over waste ages ranging from 10 to 100 years. The gamma energy emission rate is a rough measure of the radiation dose delivered to the repository components in the vicinity of the waste canisters. 
TABLE 1.5. Effect of Cesium and Strontium Removal on the Gamma Energy Emission Rate (10 $15 \mathrm{MeV} / \mathrm{sec} / \mathrm{MTE})$

Unfractionated $H L W$

FHLW (95\% Cs/Sr Removed)

$\%$ Remaining after $95 \% \mathrm{CS} / \mathrm{Sr}$ Removed
HLW Age (years)

\begin{tabular}{|c|c|c|}
\hline 10 & 50 & 100 \\
\hline 2.45 & 0.767 & 0.234 \\
\hline 0.700 & 0.075 & 0.017 \\
\hline 28.6 & 9.8 & 7.3 \\
\hline
\end{tabular}





\subsection{SUMMARY AND CONCLUSIONS}

The results of this study on the fractionation of commercial high-level waste (HLW) are summarized in this section. The purpose of this study was to evaluate the feasibility of processing commercial HLW to fractionate the cesium and strontium present in the waste to a separate waste stream for waste management purposes.

Cesium-137 and strontium-90 and their short-lived decay products account for 70 to $90 \%$ of the heat output and a larger percentage of the gamma activity of 10- to 100-year-old commercial HLW. Their presence complicates the geologic disposal of the HLW and its longer-lived components, by the resulting thermal stresses their heat imposes on the containment system. The radiological effects of their gamma activity may also cause problems for long-term containment of the HLW. This study considered the feasibility of fractionating the HLW into two components to provide a lower-temperature environment for the very long-lived components in the HLW. The two components are: 1) the relatively short-lived cesium/strontium ( $\mathrm{CS} / \mathrm{Sr}$ ) waste, and 2) the remaining HLW, referred to here as fractionated high-level waste (FHLW). The analysis encompassed the entire waste management system, including the fractionation process, waste vitrification, transportation and interim storage, and geologic disposal.

Three alternative disposal systems were compared in this study:

- a reference concept for disposal of vitrified HLW

- the Cs/Sr fractionation concept

- storage of HLW for approximately 50 years prior to disposal, which achieves a reduced heat load through decay rather than through fractionation.

The analysis centered on disposal in a deep basalt formation repository. The reasons for this choice were the relatively low thermal conductivity of basalt and the possible requirement for a bentonite-type backfill material to further constrain the dissipation of the HLW heat. It was felt that the prospects for the fractionation concept would be enhanced in this environment; that is, any advantages for the concept should be most evident under these conditions. 
The conceptual fractionation process for this study is based on removal of the cesium and strontium from the liquid HLW by an ion-exchange process employing titanium phosphate for cesium removal and hydrated antimony pentoxide for strontium removal. The basic features of the flowsheet were quantitatively confirmed by bench-scale laboratory experiments.

System costs were developed for a broad range of conditions comparing the $\mathrm{Cs} / \mathrm{Sr}$ fractionation concept with disposal of 10-year-old vitrified HLW and vitrified $H L W$ aged to achieve (through decay) the same heat output as the FHLW. Al1 comparisons in this report are based on a 50,000 metric ton equivalent (MTE) system (i.e., wastes from 50,000 metric tons of original fuel). The FHLW and the Cs/Sr waste are both disposed of as vitrified waste, but emplaced in separate areas of a basalt repository. The FHLW is emplaced in high-integrity packages at relatively high waste loading, but low heat loading, while the $\mathrm{Cs} / \mathrm{Sr}$ waste is emplaced in nominal-integrity packages at relatively high heat loading. The system cost comparisons are based on minimum cost combinations of canister diameter, waste concentration and canister spacing for each waste type in a basalt repository. The potential advantages of lower gamma radiation from the FHLW canisters were not evaluated.

The system costs were developed for a range of maximum waste package temperatures and for HLW and FHLW emplaced both with and without a bentonite clay backfill (bentonite helps seal out water from the waste canister). Other variables included maximum waste concentrations, considering minimum and maximum inert diluents in the HLW and FHLW, and repository size 1 imits of either 50,000 MTE or 2,000 acres. For 2,000-acre repository limits, some cases required several repositories and others required only a fraction of a single repository. The system costs include the fractionation process, vitrification, storage, transportation and disposal. For the bentonite backfill cases, the characterizing parameter was the maximum bentonite temperature, while for the cases without bentonite, the characterizing parameter was the maximum waste centerline temperatures. 


\subsection{RESULTS WITH BENTONITE BACKFILL}

Results for the cases that included bentonite backfill are summarized in Figure 2.1. Each point on the curves in the figure represents a minimum 50,000 MTE system cost combination of canister size, canister pitch (spacing) in the repository and waste concentration. The FHLW disposal includes the requirements for disposal of the $\mathrm{Cs} / \mathrm{Sr}$ waste component in a separate section of the same repository. To provide a common reference for comparison with cases
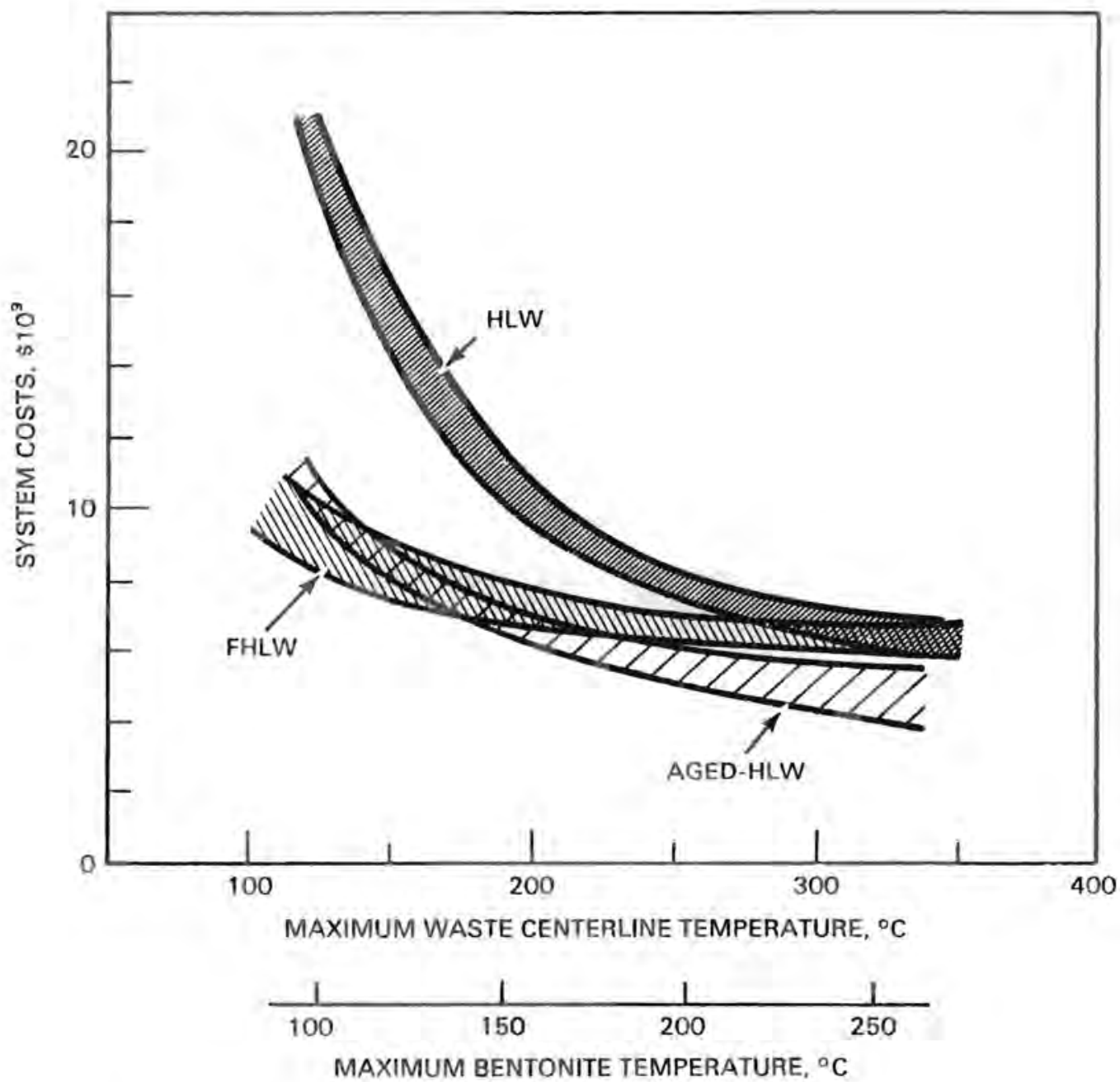

FIGURE 2.1. Total 50,000 MTE System Cost Comparison for HLW, Aged-HLW and FHLW Disposal with Bentonite Backfi11 
without the bentonite backfill, the approximate maximum waste centerline temperature is also shown in addition to the maximum bentonite temperature. At the higher bentonite temperatures, the cost ranges for the FHLW and HLW disposal system alternatives overlap, indicating no advantage for the fractionation concept. However, as the bentonite temperature or waste centerline temperature is reduced, the fractionation concept begins to show a significant cost advantage. At the $100^{\circ} \mathrm{C}$ bentonite temperature, the FHLW system costs are approximately one-half of the HLW system costs. The fractionation system costs increase quite gradually as the backfill temperature is reduced from $250^{\circ} \mathrm{C}$ to about $150^{\circ} \mathrm{C}$, indicating that substantial temperature reductions could be realized with the fractionation concept at a relatively small increase in total system costs.

The costs for the aged-HLW disposal alternative show a substantial advantage relative to HLW disposal over the entire temperature range, indicating that from a cost standpoint, this may be the most attractive alternative. However, the costs for aged-HLW disposal are equal to or greater than the costs for the FHLW disposal at the low end of the temperature range. If a cost-of-money discount rate is applied, even if only a very small one, the repository component of the system costs for the aged-HLW case would be reduced further. The major disadvantage for the aged-HLW alternative is the public perception of delayed disposal and the long period of surface storage survei1lance required.

Another important consideration in comparing these alternatives is the total repository area requirements. These area requirements are compared in Table 2.1 for repositories employing a bentonite backfill around the canisters. Reduced temperatures in the HLW disposal case are obtained by dispersing the HLW in more canisters over a larger area, whereas in the FHLW disposal case, the FHLW canisters require much less area and the primary heat producing components (cesium-137 and strontium-90) are concentrated in a separate section of the repository and are permitted to reach higher temperatures. The repository area requirements are reduced with the fractionation concept over the entire temperature range and are two-fold lower at the $100^{\circ} \mathrm{C}$ bentonite temperature. The area requirements for the aged-HLW are even lower than the 
TABLE 2.1. 50,000 MTE Repository Area Requirements for HLW and FHLW (including $\mathrm{Cs} / \mathrm{Sr}$ waste) and Aged-HLW with Bentonite Backfill, Acres

\begin{tabular}{|c|c|c|c|c|}
\hline & $\frac{\text { Maximum }}{100^{\circ} \mathrm{C}}$ & $\frac{\text { Bentonite }}{150^{\circ}}$ & $\frac{\text { Temperatur }}{200^{\circ}}$ & $\frac{e,{ }^{\circ} \mathrm{C}}{\frac{250^{\circ}}{b^{\prime}}}$ \\
\hline HLW & 5,000 & 3,500 & 2,400 & 2,000 \\
\hline FHLW & 2,500 & 2,200 & 1,800 & 1,600 \\
\hline Aged-HLW & 3,000 & 1,600 & 1,200 & 1,000 \\
\hline
\end{tabular}

FHLW at the high end of the temperature range, but are higher than the FHLW at the low end of the temperature range.

\subsection{RESULTS WITHOUT BENTONITE BACKFILL}

In the Basalt Waste Isolation Project (BWIP), the possibility of HLW emplacement without a bentonite backfill or with the backfill delayed up to 50 years after initial emplacement is being investigated. A summary comparison of total system costs for the HLW and FHLW disposal without the bentonite backfill is shown in Figure 2.2. The cost relationships are similar to those found with the bentonite backfill (Figure 2.1). System costs for HLW disposal are lower than for FHLW disposal for maximum waste centerl ine temperatures above $250^{\circ} \mathrm{C}$. Below that point, the cost advantage begins to develop for the FHLW disposal. At the very $10 \mathrm{w}$ waste centerline temperatures (for example, at $100^{\circ} \mathrm{C}$ ), the cost of FHLW disposal is approximately a factor of two lower than HLW disposal. costs for aged-HLW disposal were not developed for this delayed backfill repository concept.

The respository area requirements for cases without bentonite backfill are compared in Table 2.2. The relationships between the area requirements are generally comparable to the total system cost relationships. The area requirements for both HLW and FHLW are increased substantially at the $100^{\circ} \mathrm{C}$ centerline temperature, but more so for the HLW. 


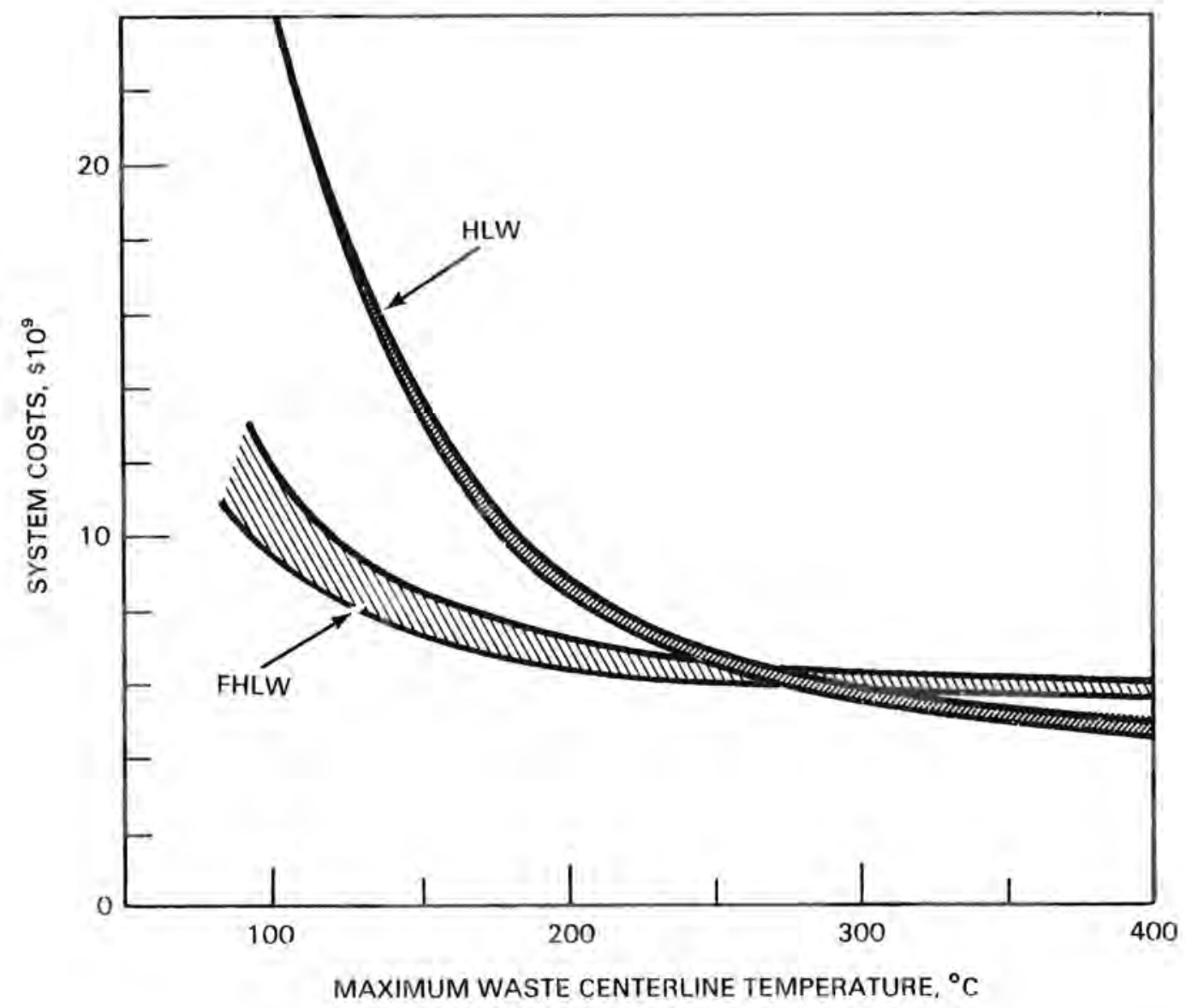

FIGURE 2.2. Total 50,000 MTE System Cost Comparison for HLW and FHLW Disposal Without Bentonite Backfill

TABLE 2.2 50,000 MTE Repository Area Requirements for HLW and FHLW (including $\mathrm{Cs} / \mathrm{Sr}$ waste) Without Bentonite Backfill, Acres

\begin{tabular}{lrrrrr} 
& \multicolumn{3}{c}{ Maximum Centerline Temperature, ${ }^{\circ} \mathrm{C}$} \\
\cline { 2 - 2 } & $\frac{100^{\circ}}{15,000}$ & $\frac{200^{\circ}}{2,800}$ & $\frac{300^{\circ}}{1,700}$ & $\frac{400^{\circ}}{1,200}$ \\
HLW & 5,000 & 1,800 & 1,500 & 1,400
\end{tabular}

\subsection{RADIOLOGICAL RISK CONSIDERATIONS}

For the near-term radiological risk analysis, both normal operations and potential accidents were evaluated for waste treatment, transportation, storage and repository operations. The largest differences in estimated radiation doses resulted from potential accidents during waste transportation. However, 
neither the magnitude of the doses nor the differences between alternatives were large enough to provide a basis for discriminating between the alternatives.

Long-term radiological risks of geologic disposal for the alternatives were also evaluated. One natural disruptive event represented by the occurrence of a geologic fault through the repository followed by water intrusion was analyzed, as was one human-induced disruptive event represented by a well-drilling accident. No significant risk or differences in either cumulative releases or maximum concentration of nuclides that might ultimately reach the environment were found for any of the three basic alternative systems examined in this study.

\subsection{ALTERNATIVE REPOSITORY CONCEPTS}

A repository emplacement concept, in which multiple HLW canisters are placed in horizontal boreholes drilled between rooms, rather than in vertical boreholes in the room floors (as assumed in this study), is currently being evaluated in the Basalt Waste Isolation Project (BWIP). In this concept, the canisters are initially emplaced without a bentonite backfill, which is added approximately 50 years later. A single heat transfer simulation was performed for this concept. From the results, it can be inferred that this concept will yield temperatures similar to the vertical borehole concept (without a bentonite backfill) when areal heat loads are equivalent. Thus, the incentive for waste fractionation should also be similar.

A heat transfer simulation was also carried out for a reference case in a salt repository. The results indicate some potential for thermal stress reduction with the fractionation concept for a salt repository, but it appears a less-attractive prospect than basalt. The conductivity of salt is higher than basalt and the temperature reductions are proportionally smaller.

\subsection{CONCLUSIONS}

The major conclusions relative to the potential advantages of the Cs/Sr fractionation concept can be summarized as follows: 
- The fractionation concept offers the prospect of achieving reduced repository temperatures in the vicinity of the HLW canisters at a substantially lower cost than $c$ an be achieved by simply diluting and/or dispersing the unfractionated HLW in more canisters over a larger repository area to attain equivalent temperatures.

- Aging HLW for 50 years or more prior to disposal can accomplish a result similar to fractionation, at equivalent or lower costs. To achieve these lower costs, the storage must be planned for at the time the HLW canisters are produced because a higher waste loading or larger waste canisters must be used than would be possible without aging. The disadvantages of this concept are the delayed disposal and the long period of surveillance required, and the concern that this might be viewed by the public as a lack of a permanent solution for the waste management.

- Storing the CS/Sr component of the waste for 50 years prior to disposal in the fractionation concept was found to cost about the same as immediate disposal in a separate section of the repository. The reduced disposal cost is offset by the cost of storage. Furthermore, this option has the same disadvantages as HLW aging and thus is not considered an attractive alternative.

- If repository waste emplacements are designed for currently designated maximum design temperatures, there appears to be no cost advantage for the fractionation concept under the process and disposal assumptions used in this analysis.

- Results of both the long- and short-term radiological risk analyses indicate that relative risk does not provide a basis for discriminating between the disposal alternatives.

Several conclusions were reached relating to general repository design considerations:

- Optimization of canister size with respect to the entire waste management system is an important factor that should be considered in repository design concepts. Optimization of the canister size can 
mitigate the impact of such factors as an expensive canister or overpack material, or a more dilute waste concentration.

- To achieve minimum waste disposal system costs, the maximum possible waste concentration should always be used, with any required adjustments for thermal limits in the repository achieved through adjustment of the canister size and spacing in the repository.

- The impact on disposal costs of a costly canister overpack material for HLW disposal can be minimized if the canister size and emplacement spacing in the repository are optimized.

- If soluble poisons, such as gadolinium, can be eliminated from the reprocessing dissolution step, the concentration of HLW components can be increased and there may be cost incentives in a basalt repository for considering smal1-diameter canisters $(0.5 \mathrm{ft}$ diameter or less), particularly if a low-conductivity backfill material is used in the repository.

The results of this study suggest several possible avenues for improving the waste fractionation concept and possibly reducing its costs. These include: 1) the possibility of using less-expensive waste forms than borosilicate glass for the Cs/Sr waste, since this waste does not need to be contained for a long time period; 2) the possibility of developing other waste fractionation processes, particularly a solvent extraction process, that would provide a more concentrated $\mathrm{Cs} / \mathrm{Sr}$ waste component and result in lower costs; 3 ) the possibility of disposing of the Cs/Sr waste at a lesser depth than the long-1ived FHLW; and 4) the possibility of higher permissible temperatures for the Cs/Sr waste, since this waste does not have to survive for such long periods as the HLW.

The analyses in this study were all based on a 95\% separation of the cesium and strontium from the FHLW. However, results of the laboratory work indicate that a $99 \%$ separation is feasible. This would reduce the heat output of the FHLW component by about $10 \%$ or more and improve the economics for the fractionation concept. 



\subsection{THERMAL ANALYSIS}

A thermal analysis was performed to provide the basis for defining waste emplacement configurations. A wide range of conditions was examined within which the optimum configurations for high-level waste (HLW), fractionated highlevel waste (FHLW), cesium/strontium (CS/Sr) waste, and aged-HLW could be determined through the cost analysis. The conditions that were considered feasible were those that met the established temperature limits on the various components of the waste package and the host rock. In addition, one of the study objectives was to examine the feasibility of waste emplacement configurations that would result in maximum temperatures well below established limits. To meet these analysis requirements, it was necessary to perform an extensive parametric thermal analysis.

The variables of the parametric analysis were the host rock, waste type, canister diameter (I.D.), canister pitch, and initial canister heat load. The emphasis of the thermal analysis was on a repository located in basalt; however, a more limited analysis was performed for a repository located in salt. The waste types were distinguishable in the thermal analysis only by their decay curves. The canister I.D. was varied from $0.5 \mathrm{ft}$ to $2.5 \mathrm{ft}$. The canister pitch (i.e., canister spacing) was varied from a minimum of 2-1/2 times the required borehole diameter to, effectively, infinity. The initial canister heat loads were specified to provide a range of peak temperatures that extended beyond the component temperature limits for the waste package. Concentration limits of waste in the glass and areal loading limits were not constraints in specifying the heat load. This allowed for correlations to be developed covering a wide range of expected temperatures as a function of heat load and provided the basis for subsequently identifying the impact of waste concentration limits and areal loading limits as separate variables. To encompass the desired range of package temperatures, achievable waste concentration limits were exceeded for some of the parametric conditions. In general, package temperature limits were exceeded before areal load limits were exceeded. 
There are a number of design and operational parameters that were not varied in the analysis. While these parameters may be important to a full repository optimization, they were not considered to be critical for the evaluation of the incentives for waste fractionation. The notable fixed conditions included the basic repository configuration and waste package designs. The waste canisters were placed individually in vertical boreholes along the emplacement room centerline. The room size and pillar width were fixed. For the waste package, the thickness of the canister, overpack, liner, air gaps, crushed rock backfill, and bentonite backfill were also fixed, with the exception that for the $\mathrm{CS} / \mathrm{Sr}$ canisters and the repository in salt, bentonite was not included in the design. The basalt repository design parameters are shown in Table 3.1 .

TABLE 3.1. Basalt Repository Design Parameters

$\begin{array}{ll}\text { Repository Depth } & 1030 \mathrm{~m} \\ \text { Emplacement Room Height } & 6.1 \mathrm{~m} \\ \text { Emplacement Room Width } & 4.3 \mathrm{~m} \\ \text { Pillar Pitch } & 23.5 \mathrm{~m} \\ \text { Canister Pitch } & \text { Variable } \\ \text { Canister Diameter } & 0.15 \text { to } 0.76 \mathrm{~m}(0.5 \text { to } 2.5 \mathrm{ft}) \\ \text { Canister Active Length } & 2.44 \mathrm{~m}(8 \mathrm{ft}) \\ \text { Canister Overpack } & \text { Steel with } 0.25 \mathrm{~cm} \mathrm{Ti} \\ \text { Canister Backfill } & 23 \mathrm{~cm}(9 \mathrm{in} .) \text { fompressed bentonite/ } \\ & \text { basalt mix }\end{array}$

(a) Throughout this report, when the term bentonite backfill is used, it refers to a $25 \% / 75 \%$ mixture of compressed bentonite and crushed basalt.

A number of simplifying assumptions were used that had an impact on the accuracy of the thermal solution. However, since each case was affected approximately to the same extent, the conclusions drawn from the analysis are not critically dependent on the level of absolute accuracy of the thermal solution. The impact of selected assumptions is discussed in Appendix A, Section A.2 (Volume 2). 


\subsection{ANALYSIS BASIS AND PROCEDURE}

The repository model that is the basis for the analysis includes a physical description of the repository and an interpretation of the physical system such that its thermal performance can be evaluated. Some of the more fundamental aspects of the physical system, including the local geology, the decay heat data, and the thermal constraints, are described in this section. Further details, including a description of the material properties and the assumptions regarding the operation of the repository, are given in Appendix A. The analysis procedure is based upon the "thermal-field" models which represent the implementation of the physical system into a computational model. The thermal-field models are described briefly in this section, while specific details are reserved for Appendix A. A description of the parametric analysis and the computer code that was applied are also given in this section. Further detail regarding the computational procedure is given in Appendix A.

\section{1 .1 Geology}

Two host rocks were included in the analysis: basalt and salt, with the bulk of the work devoted to basalt. In both cases the near-field column, which extended $200 \mathrm{~m}$ above and below the corridor floor, was considered to be composed of a uniform host rock; that is, no stratification of materials was taken into account. It was assumed that the relative incentives for fractionation would not depend on the stratigraphic detail. Available data did not justify further detail.

The basalt analysis focused to a limited extent on site-specific data. The repository was defined to be located in the Umtanum basalt flow on the Hanford Reservation at a depth of $1030 \mathrm{~m}$. The ambient temperature at repository depth and the geothermal gradient were $60^{\circ} \mathrm{C}$ and $0.045^{\circ} \mathrm{C} / \mathrm{m}$, respectively. These values were essentially those reported by $A$ ltenhofen (1981).

For the salt cases, the ambient temperature was $34^{\circ} \mathrm{C}$ and the geothermal gradient was $0.0317^{\circ} \mathrm{C} / \mathrm{m}$. These numbers were reported by Westinghouse (1981b) for a repository in salt at a depth of $600 \mathrm{~m}$. 


\subsubsection{Heat Decay Curves}

Three decay curves representing the four waste types were employed in the analysis. The three curves were for HLW, FHLW, and Cs/Sr waste. The HLW, FHLW and $\mathrm{Cs} / \mathrm{Sr}$ waste were specified as 10 years out of reactor. The fourth waste type, aged-HLW, was specified as 50 years out of reactor. The analysis incorporating the aged-HLW merely used a different point on the HLW decay curve as a starting condition. The FHLW represents remaining HLW components after 95\% of the Cs/Sr waste is removed. The decay heat data are given in Table 3.2.

\subsubsection{Thermal Constraints}

The temperature limits used in this analysis are given in Table 3.3. The limits assigned to titanium and bentonite represent the controlling constraints when those materials are used. In the case of bentonite, with its already low thermal conductivity, the low temperature limit imposes a significant constraint on the thermal loading of a waste package.

The $500^{\circ} \mathrm{C} l i m i t$ for basalt applies to the basalt nearest the waste and the $300^{\circ} \mathrm{C}$ applies to the bulk of the basalt, which may in itself limit the temperature nearest the waste. We chose to be conservative and used $300^{\circ} \mathrm{C}$ as the limiting maximum basalt temperature. This temperature is never approached with bentonite backfill. Even with the $\mathrm{Cs} / \mathrm{Sr}$ waste the maximum waste centerline temperature limits the maximum basalt temperature to about $350^{\circ} \mathrm{C}$.

\subsubsection{Thermal Field Models}

The thermal analysis of a nuclear waste repository involves three coupled regions: 1) the very-near-field, which includes the region in the immediate vicinity of the waste canister (i.e., the waste package); 2) the near-field, which includes the region of influence of a single waste canister; and 3) the far-field, which includes the entire repository and a surrounding region large enough that the influence of the repository is not observed at the boundaries throughout the time frame of interest. This analysis focused on the very-nearfield and near-field, while the far-field thermal effects were not evaluated. A previous study (Westinghouse 1981a) had indicated that for basalt, waste package temperature limits would constrain the areal thermal loading to well 
TABLE 3.2. Decay Heat Data for Three Waste Types

\begin{tabular}{|c|c|c|c|}
\hline $\begin{array}{l}\text { Years } \\
\text { Since }\end{array}$ & & tts/MTE & \\
\hline Discharge & HLW & FHLW & $\mathrm{Cs} / \mathrm{Sr}$ \\
\hline 10.0 & 1080 & 302.0 & 778.0 \\
\hline 11.5 & 1020 & 281.0 & 739.0 \\
\hline 15.0 & 907 & 235.0 & 672.0 \\
\hline 20.0 & 800 & 194.0 & 606.0 \\
\hline 25.0 & 690 & 166.0 & 524.0 \\
\hline 30.0 & 600 & 141.0 & 459.0 \\
\hline 35.0 & 506 & 124.0 & 382.0 \\
\hline 40.0 & 450 & 108.0 & 342.0 \\
\hline 45.0 & 400 & 98.5 & 301.5 \\
\hline 50.0 & 360 & 87.7 & 272.3 \\
\hline 55.0 & 310 & 79.5 & 230.5 \\
\hline 60.0 & 270 & 71.5 & 198.5 \\
\hline 65.0 & 250 & 65.0 & 185.0 \\
\hline 70.0 & 230 & 60.0 & 170.0 \\
\hline 75.0 & 200 & 55.8 & 144.5 \\
\hline 80.0 & 180 & 51.2 & 128.8 \\
\hline 85.0 & 170 & 48.0 & 122.0 \\
\hline 90.0 & 150 & 44.8 & 105.2 \\
\hline 95.0 & 130 & 41.4 & 88.6 \\
\hline 100.0 & 120 & 37.7 & 82.3 \\
\hline
\end{tabular}

(a) MTE refers to metric tons equivalent, i.e., waste produced from reprocessing spent fuel originally containing one metric ton of uranium or uranium plus plutonium. 
TABLE 3.3. Repository Temperature Limits

\begin{tabular}{lc}
\multicolumn{1}{c}{ Material } & $\begin{array}{c}\text { Maximum Al lowable } \\
\text { Temperature, }{ }^{\circ} \mathrm{C}\end{array}$ \\
Waste Glass & $500^{(a)}$ \\
Stainless Steel & $375^{(a)}$ \\
Carbon Steel & $375^{(a)}$ \\
Titanium & $250^{(b)}$ \\
Bentonite & $250^{(b)}$ \\
Basalt & $300-500^{(b, c)}$ \\
Salt & $250^{(a)}$ \\
&
\end{tabular}

(a) Scientific Applications (1978); DOE (1979a).

(b) Westinghouse (1981a).

(c) Altenhofen (1981).

below the levels for which far-field thermal effects would become important. Areal loading limits were reported in DOE (1980) to be $190 \mathrm{~kW}$ per acre for basalt and $150 \mathrm{~kW}$ per acre for salt.

In addition to the three regions noted above, an infinite field region was also analyzed in this study. By placing a single canister in an infinite media it was possible to define the uitimate minimum temperatures that could be realized for a given waste package design. This consideration removes any doubt regarding the potential benefit of increasing canister spacing.

The near-field was modeled as a three-dimensional column in rectangular coordinates. Selected temperatures from the near-field model were used to define a boundary temperature for a one-dimensional (radial) very-near-field solution. Minimum expected temperatures were computed using the infinite-field model, which was written in two-dimensional cylindrical geometry. Selected temperatures from the infinite-field model were used to define a boundary temperature for the one-dimensional very-near-field solution. This coupling of the infinite-field and very-near-field models defined minimum expected temperatures in the waste package and host rock. 


\subsubsection{Heat Transfer Code}

The heat transfer computations were performed with the computer code HYDRA-981, which is a derivative of another code, HYDRA-1, described in McCann (1980). HYDRA-1 is a finite-difference code developed for the solution of three-dimensional conduction/convection/radiation problems for fuel assemblies contained within closed canisters. Application of HYDRA-1 to this analysis involved deletion of the convection/radiation solutions and rewriting the specific problem-dependent grid. Because HYDRA-981 is written specifically for this analysis, it has the advantage of being very efficient. It is essentially a conduction code, maintaining the same solution techniques for the energy equation as described for HYDRA-1. HYDRA-981 can also be easily amended to allow special heat transfer models to be included when required.

\subsubsection{Parametric Analysis}

The parametric analysis was performed by fixing all of the design conditions, except waste type, canister diameter, canister pitch and initial canister heat load. With the design conditions specified, transient heat transfer simulations were performed for a matrix of values assigned for the canister diameter, pitch, and initial canister heat load. Each simulation was continued until the temperature had peaked in each of the waste package components as well as the host rock. The analysis was repeated for each value of canister diameter, pitch, and initial heat load, and for each waste type.

The total number of simulations required was reduced significantly when it was observed that for the reference cases in basalt, the thermal response was nearly independent of the waste-type decay curve. This allowed the HLW, FHLW, and aged-HLW to be treated by a single series of simulations. The decay curve for HLW was used. The CS/Sr waste, however, was evaluated separately because the waste package did not use a bentonite backfill and peak temperatures were significantly different.

The results of the parametric thermal analysis for a repository in basalt provided a series of plots of waste package component maximum temperatures versus canister heat load for each combination of canister diameter and pitch. By interpolation of these plots, a series of isotherm plots of canister 
heat load versus canister pitch for each canister diameter for a selected range of maximum temperatures for bentonite, basalt, and waste centerline were prepared. These plots provided the basic thermal data for the cost analysis. The results were also used to prepare a series of plots defining the design envelopes within which all thermal criteria are met.

For the reference cases in salt, the thermal response was found to be unique for the decay characteristics of each waste form. Thus, it was not possible to perform a parametric thermal analysis of one of the waste forms in salt and infer the thermal performance of the other waste forms. To treat each waste form separately would have required a large number of additional simulations and could not be accomplished within the time and funding of this project; therefore, only the reference cases for salt were evaluated.

\subsection{REFERENCE CASE RESIJLTS FOR BASALT}

A reference case for a basalt repository was first prepared for each waste type using 1-ft-diameter canisters in which the canister loading was such that one of the maximum temperature limits was closely approached. These were based on commercial HLW repository loadings developed in Westinghouse (1981a). The canister pitch was $3.6 \mathrm{~m}$ for each waste type. These reference case loadings for canister and repository are shown in Table 3.4 and the maximum temperatures calculated for the waste package components are shown in Table 3.5. Additional detailed results are presented in Appendix $A$, including: 1) the peak temperature in each component for the waste package as a function of time (Figures $A .4$ through $A .7$ ); 2) radial temperature profiles representing the thermal solution 5 years after the waste package emplacement (Figures A.8 through A.11); 3) the peak temperatures versus the initial heat load (Figures A.12 through A.15); and 4) isotherms in the near-field for the HLW (Figure A.16).

The component principally limiting heat removal (i.e., largest temperature drop) is the bentonite. Without the bentonite, as in the Cs/Sr waste case, the waste glass itself or the basalt becomes the limiting component. The maximum temperature data in Table 3.5 show that the critical temperature component in 
IABLE 3.4. Refernce Basalt Case Loadings(a)

\begin{tabular}{|c|c|c|c|c|}
\hline & HLW & FHLW & $\begin{array}{l}\mathrm{Cs} / \mathrm{Sr} \\
\text { Waste } \\
\end{array}$ & $\begin{array}{l}\text { Aged- } \\
\text { HLW } \\
\end{array}$ \\
\hline \multicolumn{5}{|l|}{ Canister Loading } \\
\hline $\mathrm{kW} /$ Canister & 1.00 & 1.00 & 2.00 & 1.00 \\
\hline Canister/MTE & 1.08 & 0.30 & 0.39 & 0.30 \\
\hline $\mathrm{ft}^{3} / \mathrm{MTE}$ & 6.75 & 1.90 & 2.44 & 1.90 \\
\hline Canister Pitch, m & 3.6 & 3.6 & 3.6 & 3.6 \\
\hline \multicolumn{5}{|l|}{$\frac{\text { Local Repository }}{\text { Loading }}$} \\
\hline $\mathrm{kW} / \mathrm{acre}$ & 48 & 48 & 96 & 48 \\
\hline Overpack & $\mathrm{Ti}-\mathrm{Cl}$ ad & $\mathrm{Ti}-\mathrm{Cl}$ ad & $\begin{array}{l}\text { Carbon } \\
\text { Steel }\end{array}$ & $\mathrm{Ti}-\mathrm{Cl}$ ad \\
\hline Backfill & $\begin{array}{c}\text { Bentonite } \\
\text { Basalt } \\
\text { Mix }\end{array}$ & $\begin{array}{c}\text { Bentonite } \\
\text { Basalt } \\
\text { Mix }\end{array}$ & $\begin{array}{l}\text { Crushed } \\
\text { Basalt }\end{array}$ & $\begin{array}{c}\text { Bentonit } \\
\text { Basalt } \\
\text { Mix }\end{array}$ \\
\hline
\end{tabular}

(a) All canisters here are $1 \mathrm{ft}$ in diameter by $10 \mathrm{ft}$ long.

TABLE 3.5. Reference Basalt Case Maximum Temperatures, ${ }^{\circ} \mathrm{C}$

\begin{tabular}{|c|c|c|c|c|}
\hline & HLW & FHLW & $\begin{array}{l}\text { Cs/Sr } \\
\text { Waste }\end{array}$ & $\begin{array}{l}\text { Aged- } \\
\text { HLW }\end{array}$ \\
\hline Waste Centerline & 295 & 289 & 418 & 302 \\
\hline Canister & 265 & 259 & 362 & 272 \\
\hline Overpack & 253 & 247 & 345 & 261 \\
\hline Bentonite & 243 & 235 & -- & 250 \\
\hline Basalt & 187 & 178 & 328 & 195 \\
\hline
\end{tabular}

the HLW, FHLW and aged-HLW cases is the titanium-clad overpack, if required, with a maximum temperature limit of $250^{\circ} \mathrm{C}$. This limit is slightly exceeded for both the HLW and the aged-HLW reference case designs. If titanium is not required, or, if the maximum allowable bentonite temperature should be much less than $250^{\circ} \mathrm{C}$, bentonite becomes the critical temperature component. The temperatures for the $\mathrm{Cs} / \mathrm{Sr}$ canister emplacements $c$ an be higher because $\mathrm{Cs} / \mathrm{Sr}$ canisters do not require either titanium or bentonite. For $\mathrm{Cs} / \mathrm{Sr}$ canisters, 
the $375^{\circ} \mathrm{C}$ temperature limit for steel appears to be the limiting component or, if the basalt 1 imit is taken as $300^{\circ} \mathrm{C}$, the basalt is 1 imiting.

The reference canister loading for the HLW, the FHLW, and the aged-HLW is $1 \mathrm{~kW}$ per canister. However, relative to HLW, about three times as much equivalent waste can be placed in the FHLW and aged-HLW canisters to achieve these loadings. In the fractionation case, approximately one canister of $\mathrm{Cs} / \mathrm{Sr}$ waste is also required for each FHLW canister so that the ratio of total canisters is about one FHLW canister plus one Cs/Sr canister to three HLW canisters. The repository area is also more efficiently used in the fractionation case, since the $C s / S r$ canisters can achieve about twice the areal thermal density in the repository as the HLW canisters.

These results demonstrated that the maximum temperatures for HLW, FHLW, and aged-HLW are very similar. We concluded that a single set of thermal calculations could be used to represent all three of these waste types. This substantially simplified the magnitude of the thermal calculation task for the subsequent parametric analysis.

\subsection{PARAMETRIC ANALYSIS RESULTS FOR BASALT}

A primary objective of this study was to evaluate the potential of the $\mathrm{Cs} / \mathrm{Sr}$ fractionation concept as a means to reduce repository thermal stress. Bentonite temperatures were used to characterize thermal stress for HLW, FHLW and aged-HLW emplacements (reduced bentonite temperatures would 1 imit all other component temperatures to well below their specified maximums), while basalt temperatures were used to characterize thermal stress for the Cs/Sr waste.

The matrix of heat transfer simulations developed in this analysis included canister diameters of $0.5,1.0,1.7$ and $2.5 \mathrm{ft}$ for HLW (also applying to FHLW and aged-HLW) and canister diameters of $1.0,1.7$ and $2.5 \mathrm{ft}$ for the $\mathrm{Cs} / \mathrm{Sr}$ waste. For each diameter, plots were made of maximum component temperatures versus canister heat load for each value of canister pitch. These results are presented in Appendix A of Volume 2, Figures A.17 through A.23. The heat loads that yielded selected temperatures in the bentonite were plotted against canister pitch. Smooth curves connecting the plotted points representing a given temperature were drawn, thereby producing selected 
isotherms for bentonite. These results are presented in Appendix $A$, Figures A.24 through A.27. For the CS/Sr waste, similar isotherm plots were prepared for a range of basalt temperatures. These plots are included in Appendix A as Figures A.28 through A.30. These isotherm plots provide the data needed to evaluate a range of emplacement thermal stress conditions.

A matrix of canister pitch versus canister heat loading for all four canister sizes for selected maximum bentonite temperatures was then prepared from the isotherm plots for use in the comparative cost analyses for HLW, FHLW, and aged-HLW. This matrix of values is shown in Table 3.6. A similar matrix of values for the $\mathrm{Cs} / \mathrm{Sr}$ waste, shown in Table 3.7, was prepared for selected maximum basalt temperatures. Both tables also show the corresponding approximate waste centerline temperature. These centerline temperatures are not always the same for all combinations in each row of data; there is a calculation variation of up to $\pm 5^{\circ} \mathrm{C}$ for the lower centerline temperatures and up to $\pm 10^{\circ} \mathrm{C}$ for the higher centerline temperatures.

These results show relatively small increases in thermal loading resulting from either increases in pitch or increases in canister diameter when a bentonite backfill is used. This is because the low-conductivity bentonite/basalt backfill mixture limits the heat release rate to the surrounding basalt rock. In the $\mathrm{Cs} / \mathrm{Sr}$ waste case without the bentonite, allowable loadings are much larger and thermal loading shows a steeper response to increases in pitch. However, even in this case the response to increasing diameter is still relatively small compared to increases in canister surface area. This is because the low conductivity of the basalt itself limits the thermal loading response to increasing canister diameters. Another point worth noting is that even though the canister heat loading increases with canister diameter, the canister volume increases as the square of the diameter and substantial waste dilution is required for larger-diameter canisters.

For each canister size, a plot was prepared to show the design envelope within which all temperature limits are met. These are shown in Figures 3.1 through 3.4 for HLW, FHLW and aged-HLW and in Figures 3.5 through 3.7 for the $\mathrm{Cs} / \mathrm{Sr}$ waste. These are plots of canister heat load versus repository heat load (i.e., kW/acre) with isotherms for the temperature limits of the waste 
TABLE 3.6. Heat Loading Limits for HLW Canisters in Basalt with Bentonite Backfill

\begin{tabular}{|c|c|c|c|c|c|c|c|c|c|}
\hline $\begin{array}{c}\text { Maximum } \\
\text { Bentonite } \\
\text { Temperature, }{ }^{\circ} \mathrm{C} \\
\end{array}$ & $\begin{array}{r}0.5 \\
\text { Diametel } \\
\text { Pitch, } \\
\mathrm{m} \\
\end{array}$ & $\begin{array}{l}-\mathrm{ft}- \\
\text { Canister } \\
\mathrm{kW/} \\
\text { Canister } \\
\end{array}$ & $\begin{array}{r}1.0 \\
\text { Diameter } \\
\begin{array}{c}\text { Pitch, } \\
\mathrm{m}\end{array} \\
\end{array}$ & $\frac{r_{\text {Canister }}}{\mathrm{kW/}}$ & $\begin{array}{r}1 \\
\text { Di amete } \\
\begin{array}{c}\text { Pitch, } \\
\mathrm{m}\end{array} \\
\end{array}$ & $\frac{\begin{array}{l}7-\mathrm{ft}- \\
\mathrm{e} \text { Canister } \\
\mathrm{kW} /\end{array}}{\text { Canister }}$ & $\begin{array}{r}2 \\
\text { Di amet } \\
\begin{array}{c}\text { Pitch, } \\
\mathrm{m}\end{array} \\
\end{array}$ & $\begin{array}{l}-\mathrm{ft}- \\
\text { Canister } \\
\mathrm{kW/} \\
\text { Canister }\end{array}$ & $\begin{array}{c}\text { Approximate } \\
\text { Maximum } \\
\text { Centerline } \\
\text { Temperature, }{ }^{\circ} \mathrm{C} \\
\end{array}$ \\
\hline \multirow[t]{4}{*}{100} & 2.0 & 0.15 & 2.4 & 0.15 & 2.9 & 0.17 & 3.5 & 0.24 & 115 \\
\hline & 3.0 & 0.17 & 4.0 & 0.19 & 4.5 & 0.23 & 5.0 & 0.33 & 120 \\
\hline & 6.0 & 0.20 & 7.2 & 0.23 & 8.0 & 0.27 & 8.0 & 0.36 & 120 \\
\hline & $\infty$ & 0.21 & $\infty$ & 0.24 & $\infty$ & 0.30 & $\infty$ & 0.37 & 125 \\
\hline \multirow[t]{4}{*}{150} & 2.0 & 0.31 & 2.4 & 0.37 & 2.9 & 0.43 & 3.5 & 0.58 & 175 \\
\hline & 3.0 & 0.38 & 4.0 & 0.47 & 4.5 & 0.55 & 5.0 & 0.71 & 180 \\
\hline & 6.0 & 0.45 & 7.2 & 0.54 & 8.0 & 0.64 & 8.0 & 0.80 & 190 \\
\hline & $\infty$ & 0.48 & $\infty$ & 0.57 & $\infty$ & 0.69 & $\infty$ & 0.82 & 195 \\
\hline \multirow[t]{4}{*}{200} & 2.0 & 0.50 & 2.4 & 0.60 & 2.9 & 0.74 & 3.5 & 0.95 & 235 \\
\hline & 3.0 & 0.61 & 4.0 & 0.76 & 4.5 & 0.91 & 5.0 & 1.12 & 245 \\
\hline & 6.0 & 0.73 & 7.2 & 0.87 & 8.0 & 1.04 & 8.0 & 1.28 & 250 \\
\hline & $\infty$ & 0.75 & $\infty$ & 0.92 & $\infty$ & 1.12 & $\infty$ & 1.34 & 260 \\
\hline \multirow[t]{4}{*}{250} & 2.0 & 0.70 & 2.4 & 0.87 & 2.9 & 1.08 & 3.5 & 1.34 & 290 \\
\hline & 3.0 & 0.85 & 4.0 & 1.09 & 4.5 & 1.29 & 5.0 & 1.58 & 305 \\
\hline & 6.0 & 1.03 & 7.2 & 1.23 & 8.0 & 1.46 & 8.0 & 1.80 & 320 \\
\hline & $\infty$ & 1.08 & $\infty$ & 1.28 & $\infty$ & 1.57 & $\infty$ & 1.88 & 325 \\
\hline
\end{tabular}


TABLE 3.7. Heat Loading Limits for Cs/Sr Waste Canisters in Basalt Without Bentonite Backfill

\begin{tabular}{|c|c|c|c|c|c|c|c|}
\hline $\begin{array}{c}\begin{array}{c}\text { Maximum } \\
\text { Bentonite } \\
\text { Temperature, }\end{array}{ }^{\circ} \mathrm{C} \\
\end{array}$ & $\begin{array}{c}\begin{array}{r}1 . \\
\text { Di amete } \\
\text { Pitch, } \\
\mathrm{m}\end{array} \\
\end{array}$ & $\begin{array}{l}-\mathrm{ft}- \\
\text { Canister } \\
\mathrm{kW/} \\
\text { Canister }\end{array}$ & $\begin{array}{r}1 . \\
\text { Diamete } \\
\text { Pitch, } \\
\mathrm{m}\end{array}$ & $\begin{array}{l}-\mathrm{ft}- \\
\text { Canister } \\
\mathrm{kW/} \\
\text { Canister }\end{array}$ & $\begin{array}{r}2 . \\
\text { Di amete } \\
\text { Pitch, } \\
m \\
\end{array}$ & $\begin{array}{l}-\mathrm{ft}- \\
\text { Canister } \\
\mathrm{kW} / \\
\text { Canister } \\
\end{array}$ & $\begin{array}{c}\text { Approximate } \\
\text { Maximum } \\
\text { Centerline } \\
\text { Temperature, }{ }^{\circ} \mathrm{C} \\
\end{array}$ \\
\hline \multirow[t]{4}{*}{300} & 2.4 & 1.38 & 2.9 & 1.71 & 3.5 & 2.11 & 370 \\
\hline & 4.0 & 1.89 & 4.5 & 2.23 & 5.0 & 2.63 & 390 \\
\hline & 7.2 & 2.26 & 8.0 & 2.67 & 8.0 & 3.11 & 415 \\
\hline & $\infty$ & 2.38 & $\infty$ & 2.80 & $\infty$ & 3.30 & 420 \\
\hline \multirow[t]{4}{*}{350} & 2.4 & 1.80 & 2.9 & 2.21 & 3.5 & 2.70 & 430 \\
\hline & 4.0 & 2.44 & 4.5 & 2.85 & 5.0 & 3.35 & 465 \\
\hline & 7.2 & 2.90 & 8.0 & 3.42 & 8.0 & 3.98 & 490 \\
\hline & $\infty$ & 3.06 & $\infty$ & 3.62 & $\infty$ & 4.22 & 500 \\
\hline \multirow[t]{4}{*}{400} & 2.4 & 2.20 & 2.9 & 2.70 & 3.5 & 3.33 & 500 \\
\hline & 4.0 & 2.98 & 4.5 & 3.51 & 5.0 & 4.11 & 520 \\
\hline & 7.2 & 3.36 & 8.0 & 4.23 & 8.0 & 4.93 & $>520$ \\
\hline & $\infty$ & 3.76 & $\infty$ & 4.48 & $\infty$ & 5.20 & $>>520$ \\
\hline
\end{tabular}




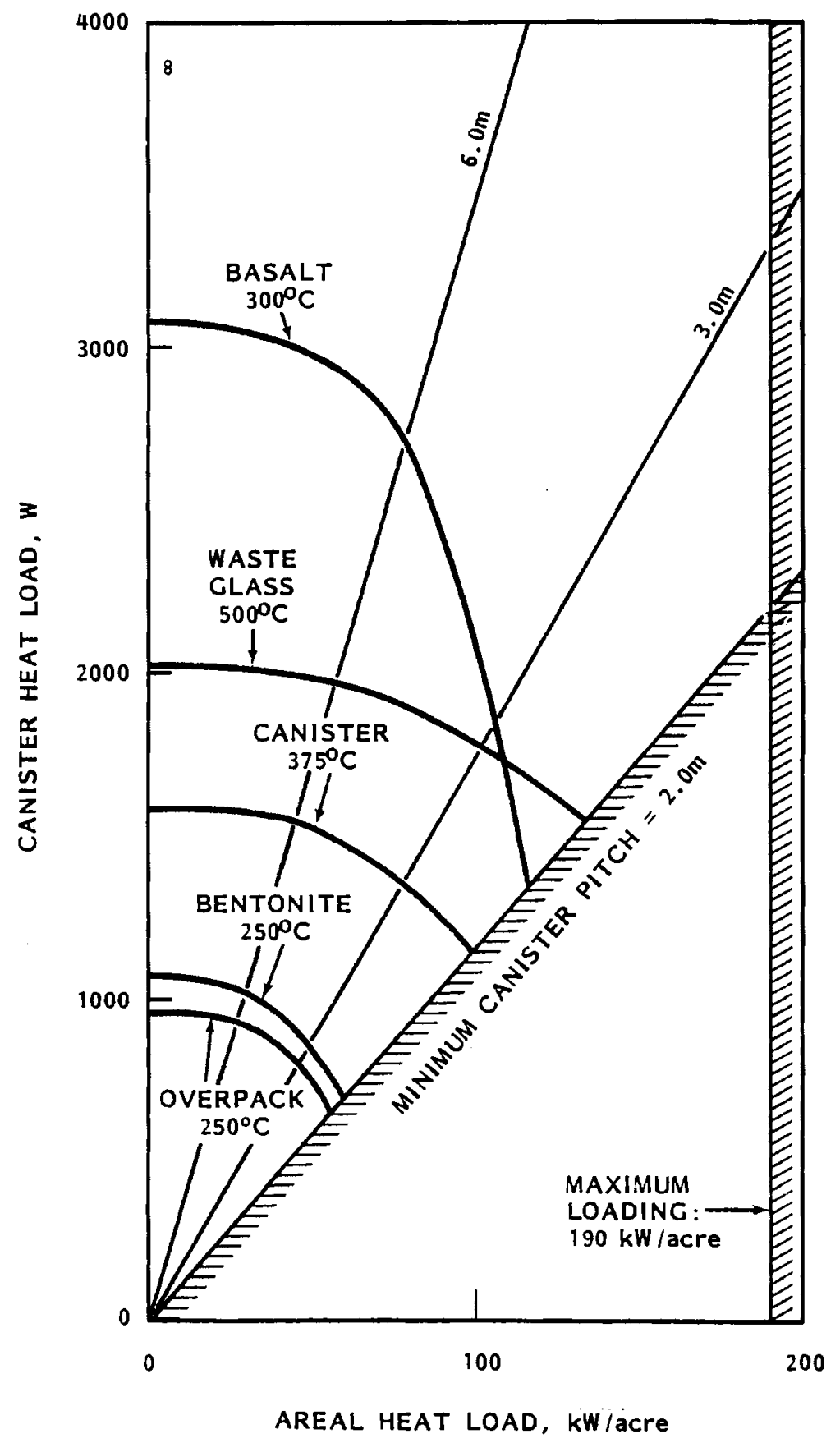

FIGURE 3.1. Thermal Loading Design Envelope for 0.5-FootDiameter HLW/FHLW/Aged-HLW Canisters 


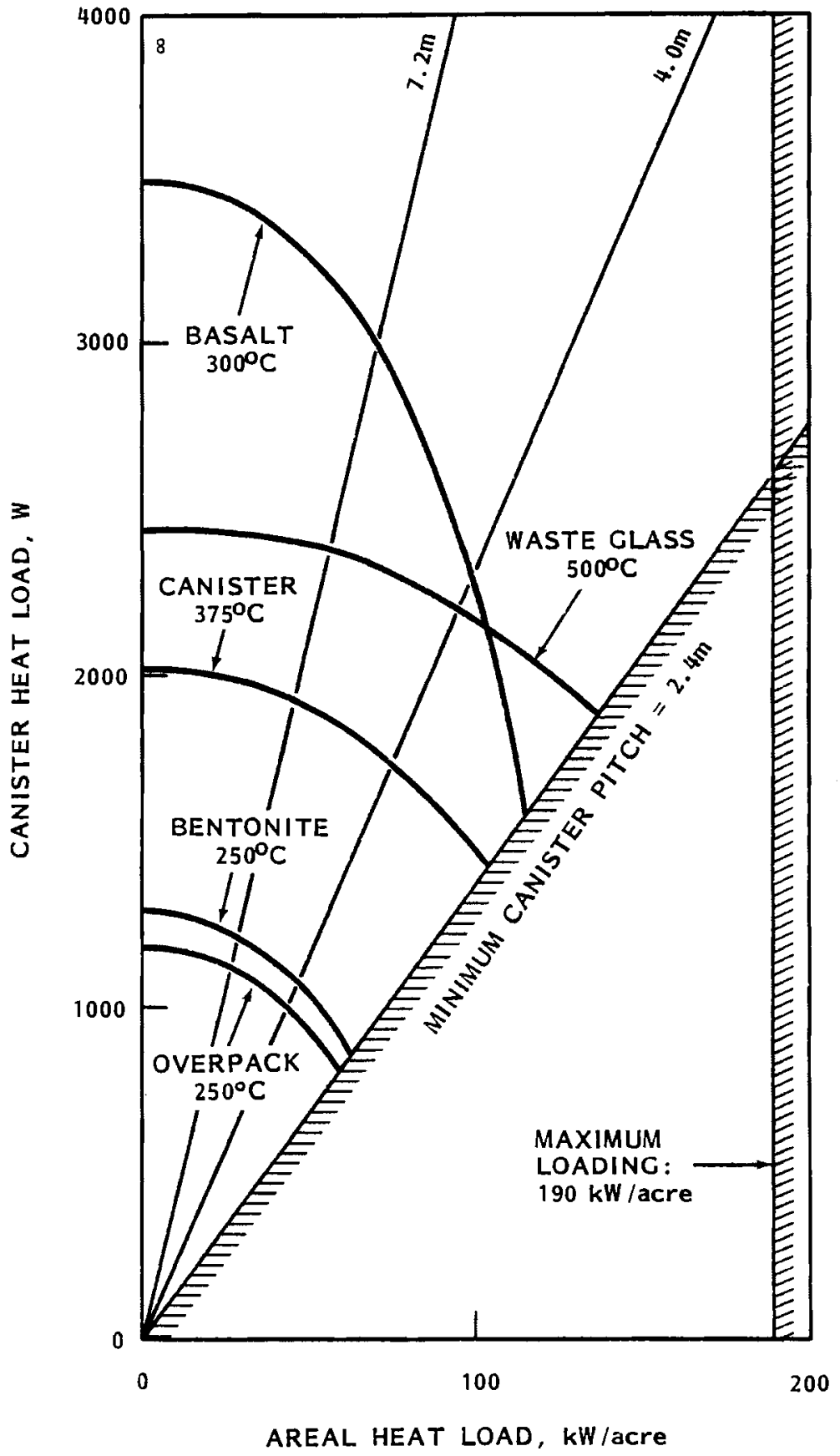

FIGURE 3.2. Thermal Loading Design Envelope for 1.0-FootDiameter HLW/FHLW/Aged-HLW Canisters 


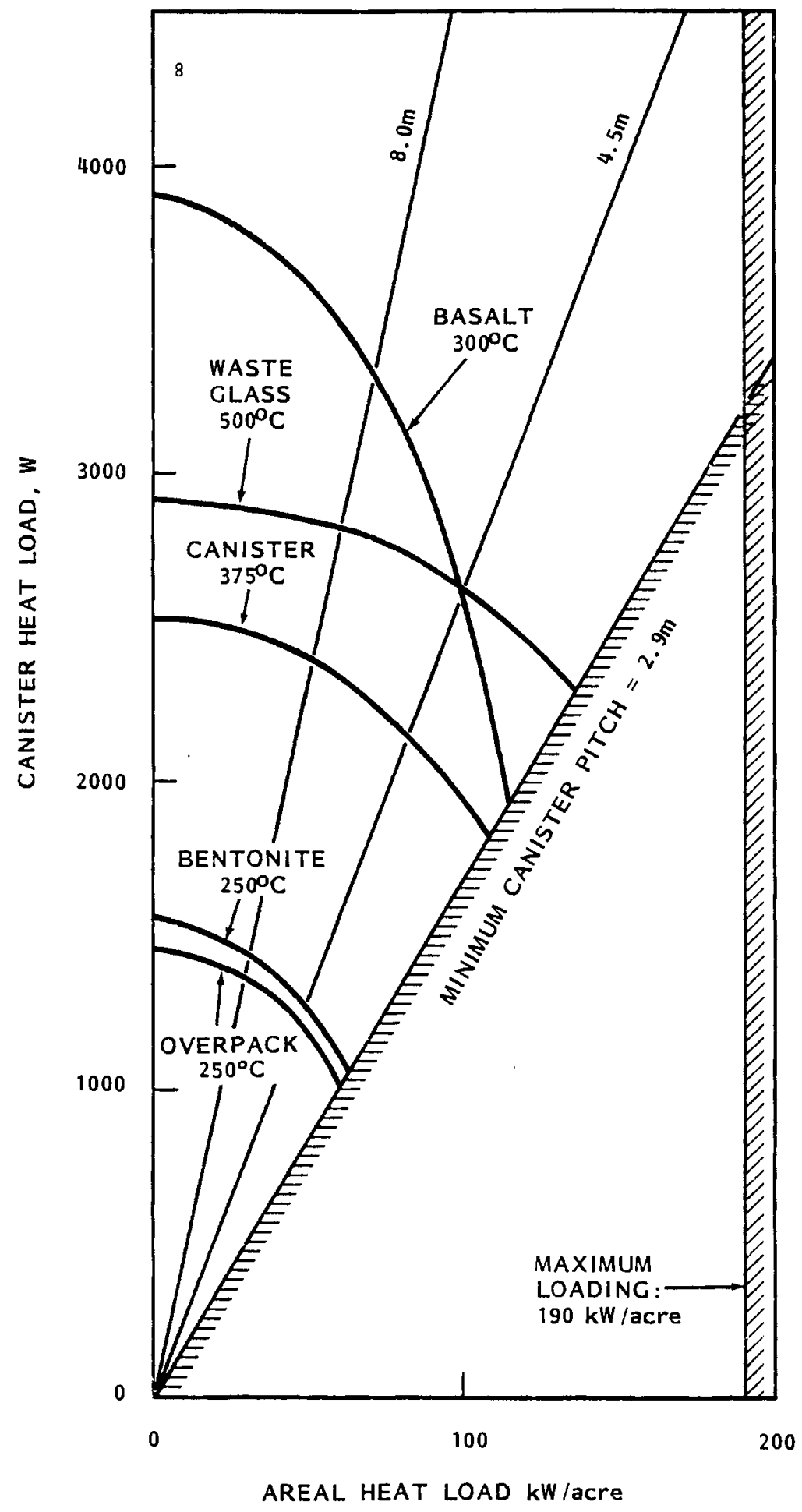

FIGURE 3.3. Thermal Loading Design Envelope for 1.7-FootDiameter HLW/FHLW/Aged-HLW Canisters 


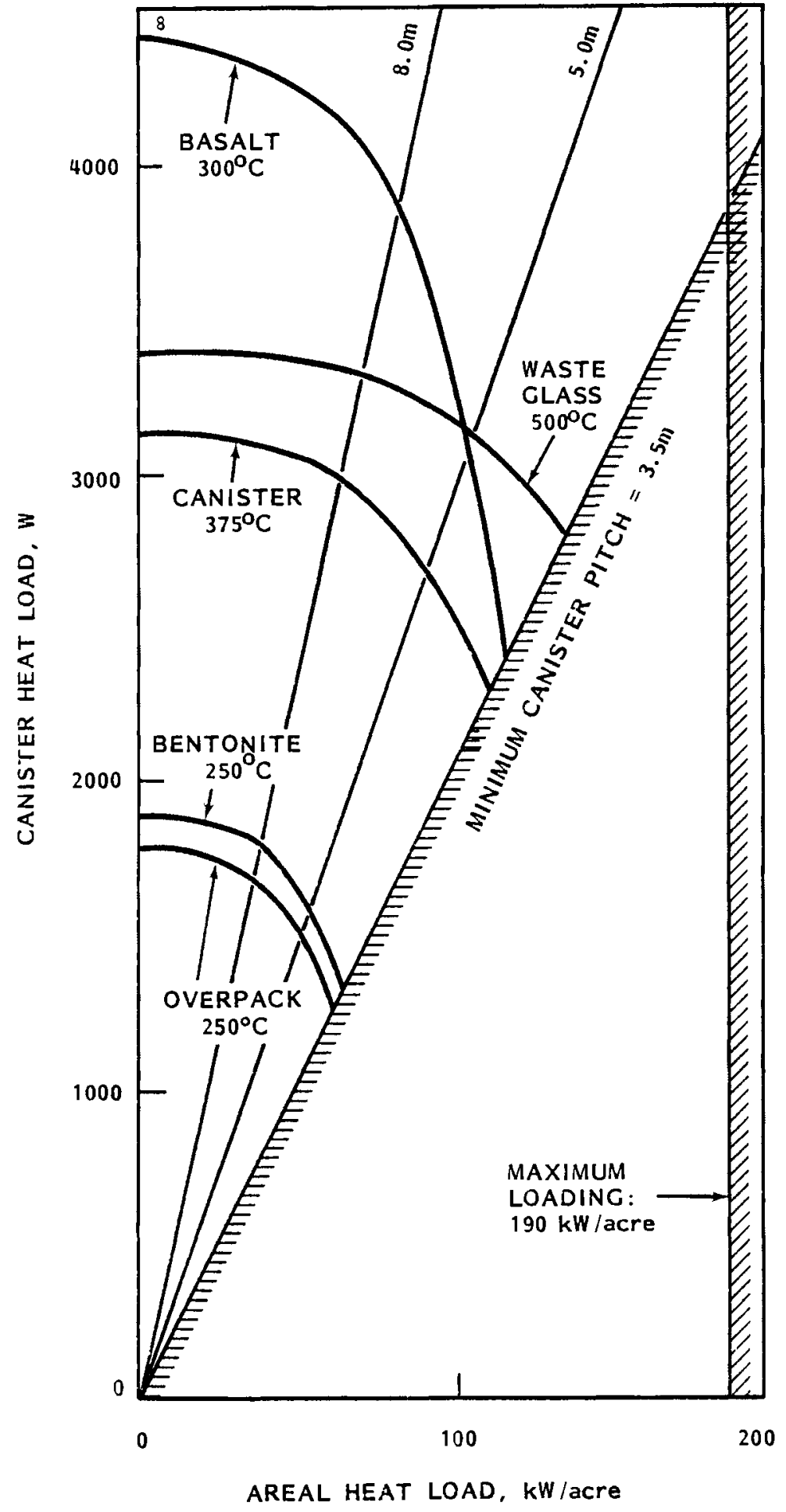

FIGURE 3.4. Thermal Loading Design Envelope for 2.5-FootDiameter HLW/FHLW/Aged-HLW Canisters 


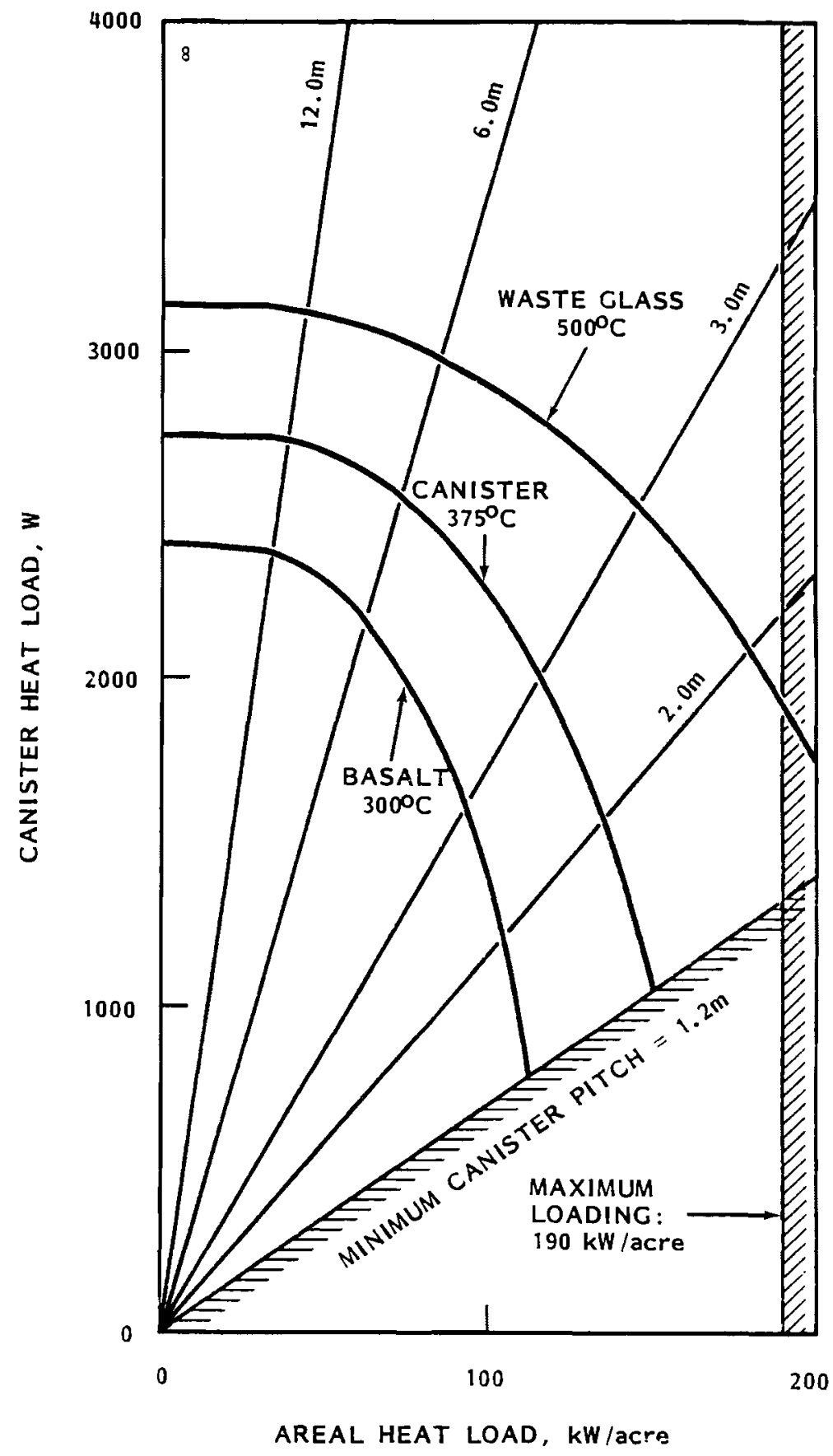

FIGURE 3.5. Thermal Loading Design Envelope for 1.0-FootDiameter Cs/Sr Canisters 


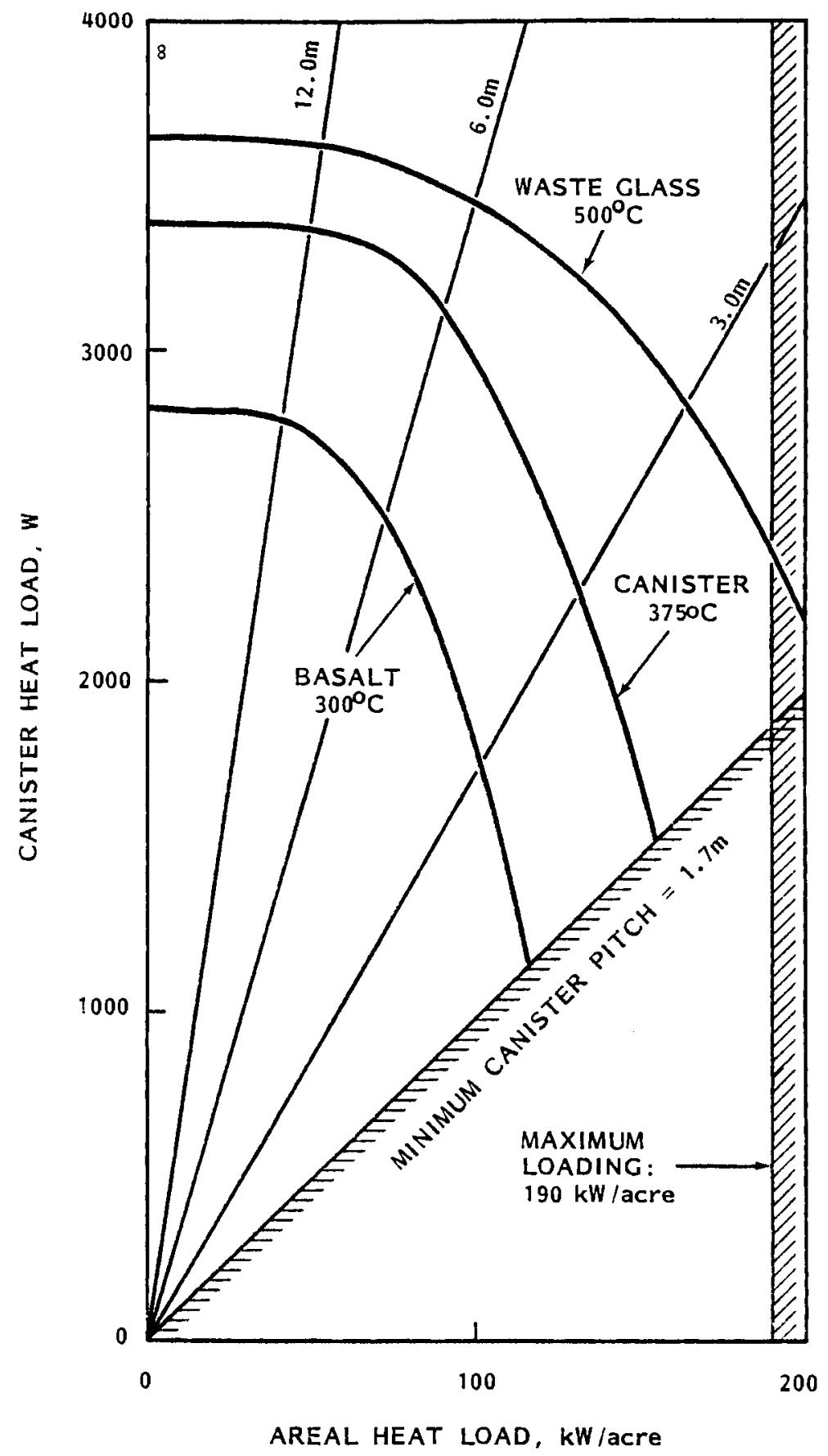

FIGURE 3.6. Thermal Loading Design Envelope for 1.7-FootDiameter Cs/Sr Canisters 


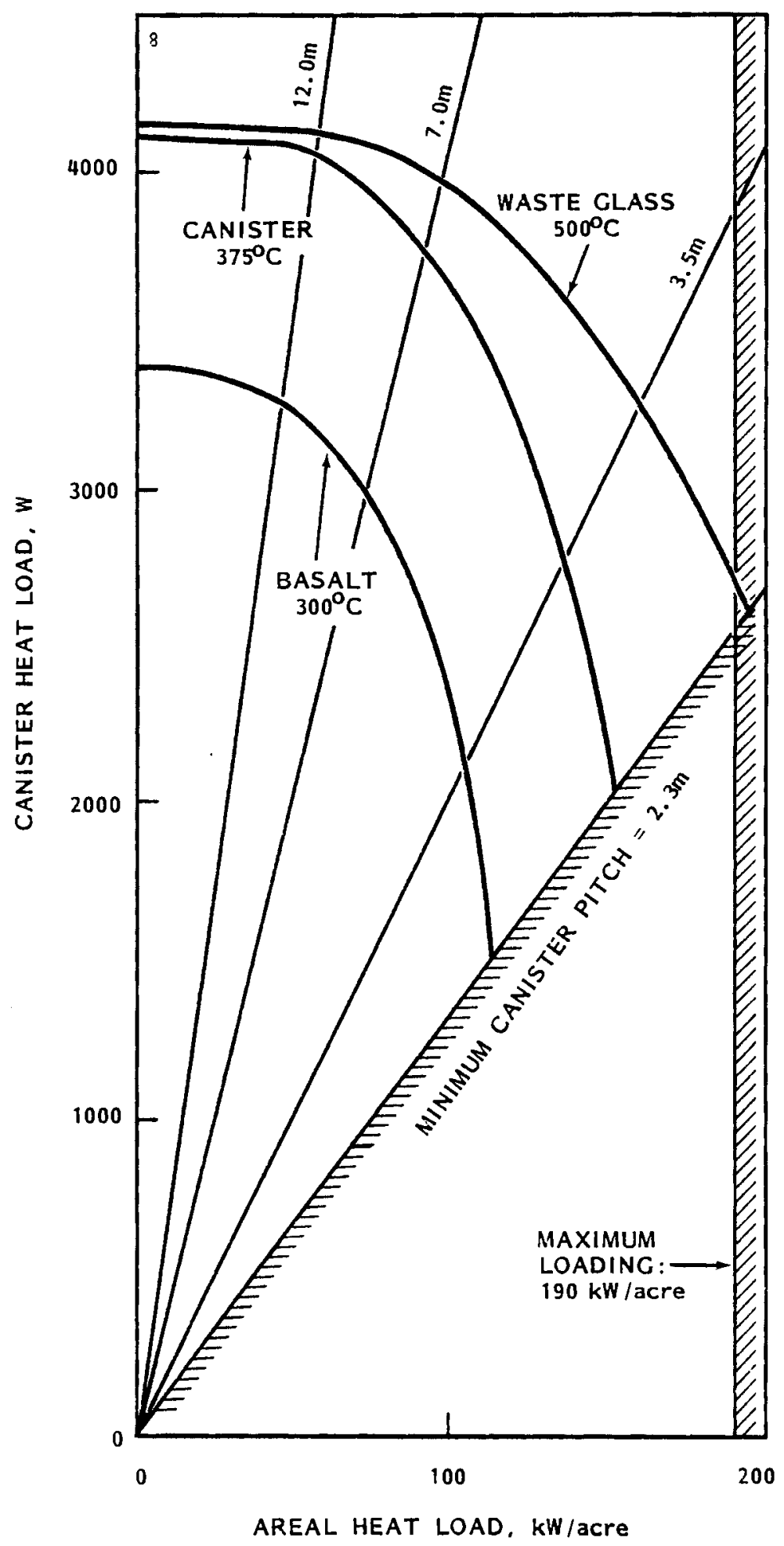

FIGURE 3.7. Thermal Loading Design Envelope for 2.5-FootDiameter Cs/Sr Canisters 
package components. The heat loading at the minimum canister pitch $(2.5$ times the hole diameter) and the areal loading limits (190 kW/acre) are additional constraints. These plots show that in no case is it likely that the maximum areal loading limit will be reached and that the envelope of allowable loading combinations is much larger without the bentonite.

\subsection{REFERENCE CASE RESULTS FOR SALT}

A reference case for a repository in a salt formation was also prepared. The canisters for each waste type were all $1 \mathrm{ft}$ in diameter. The canister heat load, based on the reference loading in Westinghouse (1981b), was $2.21 \mathrm{~kW}$. Except for the titanium cladding for the HLW, FHLW, and aged-HLW, compared to carbon steel for the $\mathrm{Cs} / \mathrm{Sr}$ canister, all of the waste package configurations were identical. The canister pitch was adjusted to produce the maximum allowable titanium temperature in the HLW case. The reference case loadings are shown in Table 3.8 and the maximum temperatures calculated for the waste package components are shown in Table 3.9.

Unlike the reference cases in basalt, the thermal response for each waste type in salt produced unique temperatures. In the absence of the lowconductivity bentonite backfill and given the high conductivity of salt versus basalt, the region surrounding the waste package in salt has an effective conductivity that is much higher than for the same region in basalt. As a result, for the cases in salt, the peak temperatures took more time to develop. This allowed the unique features of the various decay curves sufficient time to influence the thermal response of the waste package. The unique results for the reference cases indicate that it would not be possible to apply HLW results to the other waste forms, except possibly for the Cs/Sr waste.

With the process capabilities defined in this study (Chapter 4), the reference case waste concentration in Table 3.8 for FHLW and aged-HLW could not be achieved (the concentration limits for the 1-ft-diameter canister are shown in parentheses in Table 3.8). Nevertheless, these results serve to demonstrate the unique thermal response of each waste type in the salt environment. Also, 
TABLE 3.8. Reference Salt Case Loadings (a)

\begin{tabular}{|c|c|c|c|c|}
\hline & HLW & FHLW & $\mathrm{Cs} / \mathrm{Sr}$ & Aged-HLW \\
\hline \multicolumn{5}{|l|}{ Canister Loading } \\
\hline $\mathrm{kW} /$ Canister & 2.21 & $2.21 \quad(1.59)$ & 2.21 & $2.21 \quad(1.35)$ \\
\hline Canister/MTE & 0.489 & $0.137(0.19)$ & 0.352 & $0.137(0.23)$ \\
\hline $\mathrm{ft}^{3} / \mathrm{MTE}$ & 3.07 & $0.860(1.2)$ & 2.21 & $0.860(1.41)$ \\
\hline Canister Pitch & 2.84 & 2.84 & 2.84 & 2.84 \\
\hline \multicolumn{5}{|l|}{$\frac{\text { Local Repository }}{\text { Loading }}$} \\
\hline $\mathrm{kW} / \mathrm{Acre}$ & 132 & 132 & 132 & 132 \\
\hline Overpack & $\mathrm{Ti}-\mathrm{Clad}$ & $\mathrm{Ti}-\mathrm{Cl}$ ad & Steel & $\mathrm{Ti}-\mathrm{Clad}$ \\
\hline Backfill & Salt & Sâlt & Salt & Salt \\
\hline
\end{tabular}

(a) Numbers in () indicate loading limit for maximum waste concentration.

TABLE 3.9. Reference Salt Case Maximum Temperatures

\begin{tabular}{|c|c|c|c|c|}
\hline & $\underline{H L W}$ & FHLW & $\mathrm{Cs} / \mathrm{Sr}$ & Aged-HLW \\
\hline Waste Centerline & 330 & 309 & 336 & 349 \\
\hline Canister & 274 & 248 & 280 & 296 \\
\hline Overpack & 249 & 218 & 255 & 274 \\
\hline Salt & 232 & 202 & 238 & 257 \\
\hline
\end{tabular}

the lower peak temperatures for the FHLW case indicate potential for the fractionation concept to reduce thermal stresses in a salt repository. However, it appears a less-attractive prospect than basalt since there is no reduction in total ( $\mathrm{FHLW}+\mathrm{CS} / \mathrm{Sr}$ waste) canisters required relative to HLW. If the $250^{\circ} \mathrm{C}$ limit for salt could be increased for the short-lived Cs/Sr waste, the fractionation concept for a salt repository application would look more attractive. 


\subsection{ALTERNATIVE WASTE EMPLACEMENT IN HORIZONTAL BOREHOLES}

A concept of emplacing HLW in horizontal boreholes gained favor in the Basalt Waste Isolation project (BWIP) after this study was initiated. This alternative calls for construction of horizontal boreholes drilled through the pillar separating the repository rooms. Seventeen HLW canisters would be placed end-to-end in each borehole. The borehole pitch, however, is much greater $(32.6 \mathrm{~m})$ than the pitch for single canisters in vertical boreholes. The canisters are initially supported without a bentonite backfill, thereby eliminating the thermal constraint of the backfill material. An annular air space of about $6 \mathrm{in}$. would separate the canister from the basalt. Backfill material would be pneumatically emplaced around the canisters approximately 50 years later. Additional details are provided in Appendix A, Table A.10.

Time and funding limits did not allow for a complete analysis of the fractionation concept with this alternative emplacement method. However, a single heat transfer simulation was performed for the reference BWIP design. The initial canister heat load was $2.21 \mathrm{~kW}$, resulting in an areal heat load of $69.5 \mathrm{~kW} /$ acre. The resulting peak temperatures are shown in Table 3.10. These compare closely with results obtained for the same areal heat load loading and canister heat loading for the $\mathrm{Cs} / \mathrm{Sr}$ waste where the waste was emplaced in vertical boreholes without bentonite backfill (see Figure 3.5).

It can be inferred from these results that multiple canister emplacements in horizontal boreholes will result in approximately the same peak waste package temperatures as single waste canister emplacements at the same areal heat loading in vertical boreholes without backfill (i.e., like the Cs/Sr waste emplacement).

TABLE 3.10. Peak Temperatures of Waste Package Components for Horizontal Borehole Concept

\begin{tabular}{lc}
\multicolumn{1}{c}{ Component } & $\begin{array}{c}\text { Peak } \\
\text { Temperature, }{ }^{\circ} \mathrm{C}\end{array}$ \\
\cline { 2 - 2 } Waste Glass & 406 \\
Canister & 344 \\
Basalt & 313
\end{tabular}





\subsection{FRACTIONATION PROCESS DEVELOPMENT}

A number of processes have been considered to fractionate cesium and strontium from high-level waste (HLW), and one has been used on a plant-scale at Hanford (with defense HLW). The process used at Hanford was not chosen for the current study because it would substantially increase the quantity of waste glass required to contain fractionated commercial HLW. One important criterion of the current study was to minimize the volume of HLW to gain a maximum benefit from cesium/strontium ( $\mathrm{CS} / \mathrm{Sr}$ ) removal and permit a wide range of waste concentrations to be examined in the overall evaluation. Another criterion was that the transuranic element content of the fractionated cesium and strontium should be kept as low as practicable so that less-stringent disposal conditions could be postulated for the $\mathrm{Cs} / \mathrm{Sr}$ waste stream. Both of these criteria are met by the process described here. The basic concept for this process, as well as the initial process flowsheet, were developed in a previous study examining waste mixes for space disposal (McCallum et al. 1982). There may be other process concepts better suited to the waste fractionation concept examined in this study, but time and funding limitations did not allow for a broader investigation of alternatives.

The key step of the process is the sorption of cesium and strontium from moderately acidic liquid HLW onto inorganic ion-exchange materials. The loaded sorbers are subsequently mixed with suitable glass-forming materials and heated to melt the mixture and produce a glass waste form. The remainder of the HLW constituents, the fractionated HLW (FHLW), is also incorporated in a glass waste form for disposal. Other features of the process are a solution clarification step and a plutonium recovery solvent extraction step, both of which are aimed at minimizing the transuranic element content in the $\mathrm{Cs} / \mathrm{Sr}$ waste.

The previous flowsheet (McCallum et al. 1982) was based entirely on estimates from literature information. Experimental measurement of some of the important quantities was therefore made one of the prime objectives of this study. Specifically, the achievable loadings of cesium and strontium on the sorbers from simulated liquid HLW were measured, the extent of cosorption 
of americium was determined, and a Cs/Sr fraction vitrification process was developed. Results of this work are summarized here, with a more comprehensive discussion provided in Appendix B of Volume 2. A brief discussion of other possible fractionation processes is also included here.

\subsection{EXPERIMENTAL RESULTS}

The experimental work included preparation of simulated high-level liquid waste (HLLW); determination of the behavior of cesium, strontium, other fission products, and americium; and the development of a glass composition suitable for incorporation of the Cs/Sr waste.

\subsubsection{Preparation of Simulated High-Level Liquid Waste}

The reference HLLW composition for this study is the same as that in DOE/ET-0028 (DOE 1979a) except for a lower uranium content and the absence of gadolinium added as a soluble poison. This reference composition is given in Table B.1 of Appendix B. However, the simulated HLLW solution used in the experiments to determine the performance of the inorganic ion-exchange materials had a slightly modified composition, as discussed in Appendix $B$.

The HLLW was diluted twofold to minimize preparation problems. Even then problems were encountered with precipitation of solids from the simulated HLLW solution. Slow precipitation of some (unknown) materials occurred as the mixture aged. Analysis of the aged and clarified solution showed good agreement between the quantities added and those found, except for zirconium and molybdenum. The quantity of zirconium found was $50 \%$ of that added, while only $15 \%$ of the added molybdenum was found in the aged and clarified solution. Precipitation of zirconium molybdate from HLLW solutions has been observed previously by others. The diluted, aged, and clarified solution (denoted HLLW/2 to reflect the dilution factor) was then used in the sorption experiments after the addition of radioactive tracers to follow the behavior of cesium, strontium, and americium.

\subsubsection{Sorption of Cesium on Titanium Phosphate}

Efficient sorption of cesium from the HLLW/2 solution by titanium phosphate sorber was observed until the loading of cesium on the column neared 
its maximum value. For example, in one experiment, the loading of cesium on the sorber was $87 \%$ of the maximum possible (which was $0.065 \mathrm{~g}^{137} \mathrm{Cs} / \mathrm{g}$ sorber) before the cesium content of the composite effluent reached $1 \%$ of that in the feed. For an effluent containing $5 \%$ as much cesium as the feed, the cesium loading was $95 \%$ of the maximum. These results were obtained at a flow rate of 3 column volumes (CV)/hr and a temperature of $50^{\circ} \mathrm{C}$.

These results show that efficient cesium removal can be achieved with a single column of titanium phosphate that is loaded with cesium to quite near the maximum possible extent. However, it may be that the cosorption of transuranic elements decreases markedly as the cesium loading approaches its maximum value. Because cosorption of the transuranics should be minimized, an alternative approach involving the use of two columns in series may be desired. The first column can be loaded with cesium to the maximum extent possible, at which time the cesium concentration in the effluent will be equal to that in the feed, with the second column acting as a backup to remove the cesium from this effluent. By this type of operation the cesium content of the effluent is kept very low, and the transuranic element content of the cesium fraction may be minimized.

\subsubsection{Sorption of Strontium on Antimony Pentoxide}

The efficient sorption of strontium on hydrated antimony pentoxide was found to require lower flow rates and to be highly dependent on flow rate. At flow rates of 0.7 to $0.8 \mathrm{cV} / \mathrm{hr}$, the strontium content of the effluent was $<1 \%$ of that in the feed at low loadings of strontium on the sorber. However, a slight increase in flow rate to $1 \mathrm{cV} / \mathrm{hr}$ gave a large increase in the strontium content of the effluent.

At low flow rates the sorption of strontium was very efficient until the loading of strontium on the column neared its maximum value. The maximum loading of strontium on the hydrated antimony pentoxide sorber was estimated (by extrapolation) to be $0.020 \mathrm{~g} \mathrm{Sr} / \mathrm{g}$ sorber.

\subsubsection{Sorption of Americium}

A low concentration of americium (and other transuranic elements) in the separated cesium and strontium is desired so that containment requirements for 
the Cs/Sr waste can be less-stringent than for the FHLW. Americium is of primary concern here because the plutonium is removed by other processes and neptunium is not expected to be a problem.

The sorbers used to remove cesium and strontium from HLLW were found to sorb only small fractions of the americium present in the solution. In a run in which cesium was loaded onto a titanium phosphate sorber column to about $85 \%$ of the maximum level achievable and the column then washed with dilute $\mathrm{HNO}_{3}$, only $0.15 \%$ of the americium that had passed through the column was retained on the sorber. Similarly, with strontium and hydrated antimony pentoxide, $0.25 \%$ of the americium was retained in a run in which the sorber was loaded to about $85 \%$ of the apparent maximum. It may be that lower levels of americium contamination could be achieved at higher cesium and strontium loadings, but this was not tested.

\subsubsection{Sorption of Fission Products Other Than Cesium and Strontium}

One sorption run was made in which the behavior of fission products other than cesium and strontium was measured. In this case the analyses were performed by emission spectroscopy using an inductively coupled plasma (ICP) spectrometer. This run used a column made up of a mixture of equal weights of the titanium phosphate and hydrated antimony pentoxide sorbers.

The only fission product element aside from cesium and strontium to be appreciably sorbed in this run was zirconium. The data indicate that about 95\% of the zirconium fed to the column was sorbed by the exchangers. As was mentioned earlier, about half of the zirconium added had been removed as a solid before the solution was used as feed. One of the exchangers evidently did sorb some colored material, because some of the particles were blackened; it is likely that a small quantity of rubidium accounted for this.

\subsubsection{Dissolution of Sorbers}

The ICP analyses of the effluent samples also provided some information on the dissolution of the titanium phosphate and hydrated antimony pentoxide sorbers. Approximately $7 \%$ of the titanium phosphate but only $0.07 \%$ of the antimony pentoxide dissolved in this run. 


\subsubsection{Vitrification of Cesium- and Strontium-Loaded Sorbers}

To provide a waste form suitable for disposal, the feasibility of vitrifying the cesium-loaded (titanium phosphate) and strontium-loaded (hydrated antimony pentoxide) sorbers was tested. It may be that a lesscostly waste form would be suitable for disposal of these materials, because of the relatively short half-lives of the cesium and strontium and the low content of transuranic elements. However, by immobilizing these materials in glass we would have a very adequate waste form, and the estimated cost of immobilization would likely be overstated rather than understated.

Because of the limited amount of readily available hydrated antimony pentoxide sorber material, the scouting vitrification studies used antimony trioxide (unhydrated) instead. The titanium phosphate used here, however, was from the same stock as that used in the sorption experiments described earlier.

Mixtures of these materials and various glass-forming materials were combined and melted in air in porcelain crucibles. Melt time and temperature were 3 hours and $1100^{\circ} \mathrm{C}$, respectively. After melting, the crucible containing the molten glass was removed from the furnace, and the relative fluidity of the glass noted. The glass was then cooled in air to room temperature. Its homogeneity was observed, and the degree to which it had fully melted or only partially reacted was recorded. A commercially available pre-melted glass former mixture, Frit 131, was found to satisfactorily incorporate either or both of these materials and to accept high waste loadings. The composition of this frit is given in Appendix $B$.

Waste loadings of up to $25 \mathrm{wt} \%$ were achieved with either titanium phosphate or $\mathrm{Sb}_{2} \mathrm{O}_{3}$ in Frit 131. At these levels a homogeneous glass resulted, although the opaque appearance of the melts containing titanium phosphate was most likely due to a liquid-liquid phase separation in these glasses. When combinations of the two materials were vitrified, it was found that up to 25 wt\% of either could be present in a glass containing the other. That is, up to $25 \mathrm{wt} \%$ of titanium phosphate and up to $25 \mathrm{wt} \%$ of antimony trioxide could be incorporated into a single melt. Each sorbant appears to have an independent 
effect on the glass. Very little weight loss was observed in these experiments, indicating that titanium phosphate and antimony trioxide were stable in the glass.

Foaming was found in glasses containing $\mathrm{Sb}_{2} \mathrm{O}_{3}$. This may have been due to release of oxygen by multivalent oxides in the glass. Addition of elemental silicon as a reducing agent eliminated the foaming but resulted in reduction of metal, possibly antimony, from the glass. Careful control of the glass oxidation state during processing should allow the foaming to be controlled without metal reduction.

The density of these glasses is about $2.7 \mathrm{~g} / \mathrm{cm}^{3}$. This will not be significantly affected by variations in waste loading and waste type.

One vitrification run was made with actual cesium- and strontium-loaded sorbers. The sorbers used were those employed in the (nonradioactive) experiment to study the behavior of other fission products, which was described in an earlier section. Approximately equal weights of the two sorbers were used, and the weight of Frit 131 that was added was approximately equal to the weight of the combined sorbers before they were loaded with the cesium, strontium, and zirconium from the HLLW/2 solution. This vitrification run was very satisfactory; no problems were noted, and the quality of the glass produced appeared to be very high.

The glasses developed in this study were preliminary compositions made to demonstrate feasibility and to show that high levels of antimony oxide and titanium phosphate could be incorporated in glass. These glasses are not presented as recommended compositions for vitrification of the strontium and cesium sorber wastes. Development of a composition specifically for incorporation of these sorbers will be required before the processing and repository-related characteristics of such a glass can be assessed.

\subsection{REVISED FRACTIONAT ION FLOWSHEET}

The results of the experimental work were generally in good agreement with the earlier estimates on which the preliminary reference flowsheet was based. However, some flowsheet revision was indicated by the experimental 
results. A revised flowsheet is shown schematically in Figure 4.1; more detail is contained in Appendix B.

The first two process steps, HLW clarification and solvent extraction, serve to remove plutonium so that the amount of this long-lived material associated with the $\mathrm{Cs} / \mathrm{Sr}$ fraction will be minimized. The clarification step also reduces the likelihood of column plugging during the Cs/Sr sorption step.

The separated solids, estimated here to contain $80 \%$ of the plutonium in the HLLW, are washed and then routed to FHLW vitrification. These solids will also contain large fractions of the precious metals and zirconium and molybdenum, and depending on the efficiency of washing, small fractions of all of the other materials present ( $1 \%$ of the cesium and strontium are assumed to accompany these solids).

The solvent extraction step is aimed solely at removing most of the plutonium remaining in the HLLW (estimated as $0.1 \%$ of that in the fuel) to minimize the amount of plutonium in the Cs/Sr fraction. Conservatively, only $95 \%$ extraction of this plutonium is estimated, leaving $5 \times 10^{-5}$ as much plutonium in the HLLW as is present in the spent fuel being processed. The organic extract from this step is assumed to be recycled to the main fuel reprocessing plant for recovery of the contained plutonium and treatment of the solvent.

A possible alternative process for minimizing the plutonium content of the CS/Sr fraction, which could be used either instead of or in addition to the solvent extraction step, would be to treat the HLLW to reduce the plutonium from the tetravalent state to the trivalent state or to oxidize it to the hexavalent state. Tetravalent plutonium is sorbed along with the cesium and strontium, but trivalent plutonium, by analogy with the behavior observed for americium, and hexavalent plutonium, by analogy with the behavior reported for uranium, would be sorbed very little. This process concept has not been evaluated, however.

The solvent extraction step also reduces the concentration of $\mathrm{HNO}_{3}$ in the $H L L W$, which is desirable for more efficient Cs/Sr sorption. The acidity of 


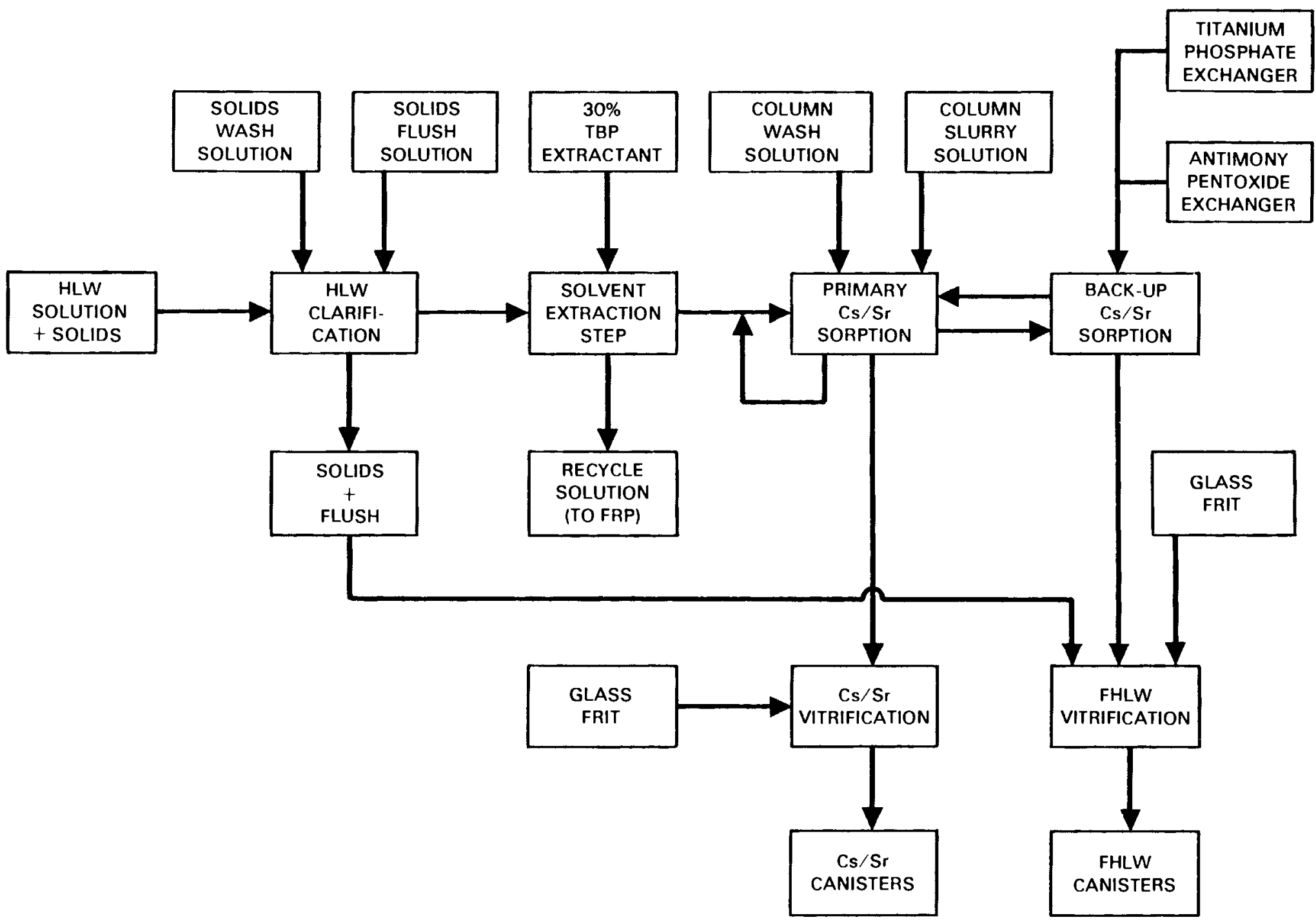

FIGURE 4.1. Revised CS/Sr Fractionation Flowsheet 
this solution is further reduced (to 1 M) by blending in the sorption column wash solution before the solution is fed to the primary Cs/Sr sorption column.

The Cs/Sr sorption columns contain (for the reference feed) nearly equal weights of the two sorber materials, titanium phosphate and hydrated antimony pentoxide. They are mixed together in one column rather than contained in separate columns because the combined vitrification process developed in the experimental work allows this simpler mode of operation. A secondary benefit of this mode of operation may be that the experiment with a mixed bed had no problems with column plugging and flow control, while those with hydrated ant imony pentoxide alone did suffer from such problems.

The flow rate of the diluted HLLW through the combined Cs/Sr sorbent columns must be kept fairly low ( 0.7 column volumes/hr) even at a temperature of $50^{\circ} \mathrm{C}$ to allow good strontium recovery and loading. At this rate, about 17 hours would be required for a loading cycle on a column large enough to handle 1-day output of HLLW from a 6.67 MTHM/day reprocessing plant.

Two Cs/Sr sorption columns in series are provided to allow maximum $\mathrm{Cs} / \mathrm{Sr}$ loadings to be achieved, which may be required to minimize americium contamination of the $\mathrm{Cs} / \mathrm{Sr}$ (although it has not been shown that high loadings are indeed necessary to accomplish this). The primary column is loaded to about $85 \%$ breakthrough, with the backup column serving to maintain very low $\mathrm{Cs} / \mathrm{Sr}$ levels in the FHLW, before feed flow is diverted from it directly to the backup column. At this time, a third column is brought on line as a new backup column, with the initial backup column becoming the new primary column.

The primary column is washed with dilute $\mathrm{HNO}_{3}$ to remove the residual feed solution and thus minimize the transuranic element contamination of the $\mathrm{Cs} / \mathrm{Sr}$. This wash solution also contains appreciable amounts of cesium and strontium, so it is recycled. This recycle stream also serves to dilute the incoming feed solution to $1 \mathrm{MHNO}_{3}$, for improved sorption efficiency.

The washed sorbers are then transferred to the Cs/Sr vitrification process. There they are mixed with the appropriate quantity of glass frit and melted to form a glass, encapsulated in steel canisters. This waste stream is estimated to contain about $99 \%$ of the cesium and strontium and about $80 \%$ of 
the zirconium present in the processed fuel. The transuranic element content of this $\mathrm{CS} / \mathrm{Sr}$ fraction should be about $0.5 \%$ of the americium and curium, $<0.5 \%$ of the neptunium, and $0.005 \%$ of the plutonium in the spent fuel. The americium and curium contents are based on the experimental work, the neptunium content is based on the assumption that neptunium would be lessstrongly sorbed than americium, and the plutonium content is based on the estimated removal in the solvent extraction step.

The HLLW solution after passing through the Cs/Sr sorption columns in series contains only about $0.5 \%$ or less of the cesium and strontium present in the feed. It is mixed with the solids initially separated from the HLLW (estimated to contain 1\% of the cesium and strontium) and with glass frit and is melted to form a glass, which also is encapsulated in steel canisters. This FHLW stream contains only about $1 \%$ of the cesium and strontium but essentially all of the americium, curium, and neptunium present in the untreated HLLW. The volume of glass required to immobilize the FHLW is not increased (relative to the HLW) due to the addition of chemicals during the processing; the required volume is actually decreased slightly because of the removal of the cesium, strontium, and zirconium.

An estimated $1 \%$ of the $\mathrm{CS} / \mathrm{Sr}$ will be present in the FHLW in this revised flowsheet, whereas $5 \%$ was estimated for the preliminary flowsheet. This downward revision is based on the more complete understanding now available as a result of the experimental work. However, because of the concurrent work on the various tasks of this study, other portions of the study were based on $5 \%$ of the $\mathrm{Cs} / \mathrm{Sr}$ being present in the FHLW.

Other flowsheet values that were revised as a result of the experimental work are the volumes of the vitrified waste fractions. The Cs/Sr vitrification process development work provides the basis for a volume of 1.73 $\mathrm{ft}^{3}$ /MTHM for this fraction (vs. the original estimate of $2.0 \mathrm{ft}^{3} /$ MTHM). The volume of the vitrified FHLW fraction is increased to $1.3 \mathrm{ft}^{3} /$ MTHM, from the original estimate of $1.2 \mathrm{ft}^{3} /$ MTHM, because of the addition of titanium and phosphate dissolved from the sorber. This revision maintains the same $30 \%$ loading of waste oxides in the glass as in DOE (1979a); the $1.2 \mathrm{ft}^{3} /$ MTHM value 
could be achieved by using a $33 \%$ loading of waste oxides, which is still within the acceptable range.

Some reprocessing concepts include features that give a larger volume of vitrified HLW. One such concept is the use of gadolinium (as a soluble neutron poison) in the dissolver. This feature is included in the AGNS plant flowsheet, as described in Slate, Ross and Partain (1981); the vitrified HLW volume of that study is $3.14 \mathrm{ft}^{3} /$ MTHM. This is much greater than the 1.41 $\mathrm{ft}^{3} /$ MTHM value calculated for the untreated HLW from the process assumed in this study; most of the difference is due to the presence of gadolinium in the AGNS flowsheet, but a higher uranium concentration and a slightly lower waste loading also contribute. The FHLW volume resulting from the AGNS flowsheet waste would be $2.70 \mathrm{ft}^{3} /$ MTHM.

\subsection{OTHER FLOWSHEET CONSIDERATIONS}

The fractionation process studied here seems to be well suited for the proposed use. It allows the two prime criteria of: 1) maintaining a minimum quantity of HLW to be vitrified for disposal, and 2) maintaining a relatively low transuranic element concentration in the $\mathrm{Cs} / \mathrm{Sr}$ fraction to be achieved, and the cost appears to be reasonable. Additional study could undoubtedly improve it even more.

The major area where the process may be improved by additional study is in the behavior of the transuranic elements. It may be possible to eliminate the solvent extraction step to remove the soluble plutonium from the HLLW by adjusting the valence of the plutonium away from plutonium (IV), so that the plutonium would pass through the sorbers along with the americium and the neptunium. It also may be possible to eliminate the backup column; this could be done if the americium content of the cesium- and strontium-loaded sorbers does not increase markedly if the cesium and strontium loadings are reduced to the point that the concentrations of cesium and strontium in the primary column effluent are at an acceptably low level.

An unresolved problem that threatens successful application of a process such as this is the precipitation of solid materials from the HLLW solution. Even if the solution is well clarified before the $\mathrm{Cs} / \mathrm{Sr}$ fractionation process 
is begun, new solids may form before the solution has completed its passage through the process. Such solids could plug the ion-exchange column.

One of the attractive features of the $\mathrm{Cs} / \mathrm{Sr}$ fractionation process studied here is that only a small amount of material is added to the FHLW solution, so that the volume of glass required to immobilize this waste stream is not increased. In comparison, the $\mathrm{CS} / \mathrm{Sr}$ fractionation process described in Exxon (1978), which also involves sorption of the cesium on titanium phosphate but uses solvent extraction with di-(2-ethyl hexyl) phosphoric acid to remove the strontium, would result in a large increase in the quantity of vitrified waste. The quantity of sodium added in the process described in Exxon (1978) is such that the quantity of vitrified FHLW would be about twice that in the process studied here.

However, the process studied here is not well suited for the recovery, for possible beneficial use, of the cesium and strontium from the HLLW (this was not a goal of this study). This is primarily because of the difficulty in efficiently eluting the strontium from the hydrated antimony pentoxide sorber. A solvent extraction process, such as that used in Exxon (1978), overcomes this problem and does allow efficient recovery of purified cesium and strontium for possible beneficial use.

An alternative $\mathrm{Cs} / \mathrm{Sr}$ fractionation process that could be desirable from several standpoints would be a solvent extraction process (or processes) to extract cesium and strontium from moderately acidic solutions. This could minimize potential solids problems, because pulse columns are quite tolerant of solids, and should require only small additions of salts to the waste. Purified cesium and strontium fractions could be recovered and packaged either for disposal or for potential beneficial use.

Unfortunately, however, no such process has yet been defined. There is some information in the literature indicating that such a process could be feasible, but much testing and development work remains to be done. If the benefits of such a process are deemed to be sufficiently high, this could be a fruitful area for additional research and development. 


\subsection{COST ANALYSIS}

Cost estimates were developed for each of the major components of the high-level waste (HLW) disposal system so that the alternatives evaluated in this study could be compared on the basis of total system costs. The basis of and results of the component cost estimates are described in Section 5.1, and system cost comparisons are described in Section 5.2 .

\subsection{COMPONENT COST ESTIMATES}

The major cost components of the waste system for this analysis include the fractionation process; waste vitrification processes for $H L W$, fractionated high-level waste (FHLW) and cesium/strontium (Cs/Sr) waste; transportation; interim storage and the geologic repository.

\subsubsection{Fractionation Process Costs}

Preliminary estimates of the Cs/Sr fractionation process costs were developed based on the process being incorporated in a 2000 MTHM per year spent fuel reprocessing plant during its original construction. Processing rates were based on a 300 day per year operation with a feed rate of 1500 gallons per day of concentrated HLW. The estimates were based on cost estimates developed for the West Valley demonstration project by Hill et al. (1981), together with cost estimates for processing commercial HLW in a 2000 MTHM reprocessing plant in DOE (1979a). Hill (1981) provides detailed equipment costs, while DOE (1979a) provides total facility costs for a variety of waste management facilities associated with a $2000 \mathrm{MT} / \mathrm{yr}$ fuel reprocessing plant.

Using the Cs/Sr fractionation flowsheet described in Chapter 4, Figure 4.1, the major processing equipment requirements were defined in a process flow diagram shown in Figure 5.1. Appropriate costs for most of the fractionation equipment items of the required size were obtained from $\mathrm{Hill}$ (1981). The total fractionation facility cost was estimated by assuming this cost to be proportionate to the ratio of total facility cost to total equipment costs for the waste vitrification facility described in DOE (1979a). (Equipment costs for the waste vitrification facility described in DOE (1979a) were developed based also on equipment costs in Hill (1981), while the total 


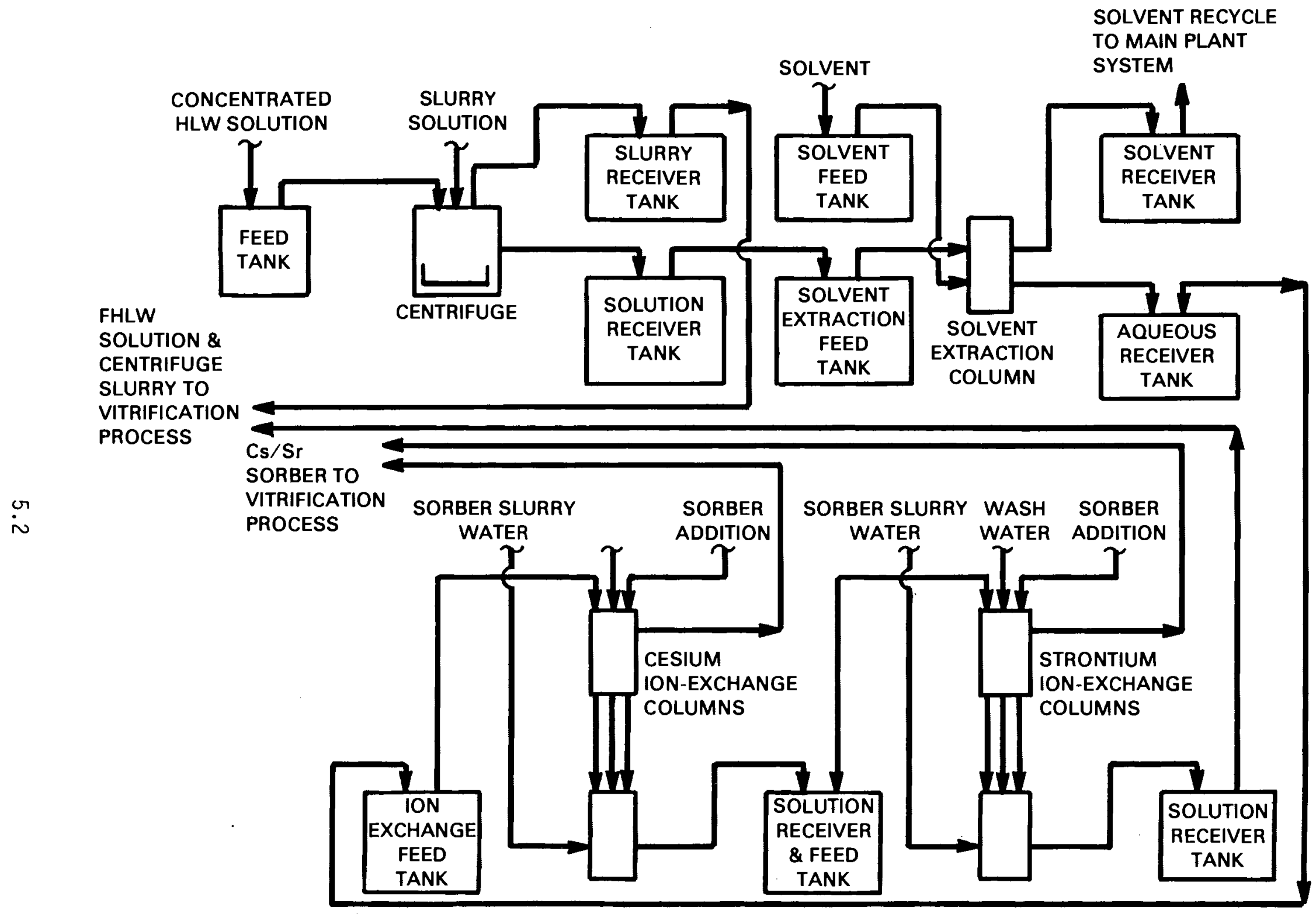

FIGURE 5.1. Fractionation Process Equipment Flow Diagram 
vitrification facility cost was obtained from DOE (1979a)). Using a factor of 1.71, the cost was escalated from the 1976 cost basis used in DOE (1979a) to a 1982 base. This resulted in a total fractionation process facility cost estimate of $\$ 111$ inilion. The operations and maintenance requirements for these two facilities as well as the building and shielding requirements are sufficiently similar that this scaling of the facility costs according to the equipment cost is believed to provide a reasonably representative cost estimate. A similar procedure was used to develop the estimated operating cost of $\$ 7.5 \mathrm{mil}$ lion per year.

A $25 \%$ fixed charge rate was used to convert the total facility cost to an annual capital charge. The $25 \%$ fixed charge rate is equivalent to a $12 \%$ uninflated constant dollar cost of capital and a 20-year plant economic life. This includes an allowance for state taxes, insurance and property taxes (see DOE 1979a, Figure 3.8.1). Adding in the operating cost and dividing by 2000 MTE per year results in a unit cost of $\$ 17,600$ per MTE. The total cost for the 50,000 MTE system used in this analysis as a basis for comparing the alternatives is then $\$ 880$ million. These results are summarized in Table 5.1 .

\section{TABLE 5.1. Estimated Costs for a Cs/Sr Fractionation Facility}

Total Capital Cost

Annual Operating Cost

Annual Capital Charge

Total Annual Costs

Unit Cost

50,000 MTE System Cost
1982 Dollars

$111 \times 10^{6}$

$7.5 \times 10^{6}$

$27.8 \times 10^{6}$

$35.3 \times 10^{6}$

$17.6 \times 10^{3} / \mathrm{MTE}$

$880 \times 10^{6}$

Adding a Cs/Sr fractionation facility to an existing reprocessing plant (as would be required in the case of the AGNS plant) would cost substantially more if added separately, but if included as part of an add-on vitrification plant, the fractionation process cost increment should not be greatly 
different. However, the throughput capacity of the Barnwell plant is now estimated to be only about 1,200 MTHM, so the unit fractionation cost might be much larger.

The flow diagram in Figure 5.1 provides for separate cesium and strontium ion-exchange columns. This was based on an earlier process concept rather than the final process described in Chapter 4, Figure 4.1, where a combined sorption process was found to be feasible. Thus, the facility requirements can be simplified somewhat compared to those in Figure 5.1.

\subsubsection{Waste Vitrification Process Costs}

Vitrification cost estimates were also based on a facility that would be associated with a 2000 MTHM per year reprocessing plant operating 300 days per year. Costs for two alternatives were evaluated. In the first, the facility includes only a single process for converting normal liquid HLW to vitrified HLW. In the second alternative, the facility includes two vitrification processes, one for vitrifying fractionated HLW and the other for converting the separate $\mathrm{Cs} / \mathrm{Sr}$ fraction to vitrified wastes. For both alternatives, relationships were developed for estimating vitrification costs as a function of canister production rate and vitrified waste volume in terms of canister size. As in the case of the fractionation facility estimate, the cost estimates are based on equipment cost information from Hill (1981) and commercial HLW vitrification facility costs from DOE (1979a).

The facility requirements for vitrified waste canister load-out and onsite storage were not considered in this analysis. It was assumed that the spent fuel receiving and storage facilities would be designed to also serve this purpose. A more detailed analysis of these requirements may be desirable, but could not be accomplished within the scope of this study. These requirements can be expected to vary in a manner similar to the vitrification costs described here, which would further enhance the importance of canister size and vitrified waste volume in the overall system costs.

The base case for the HLW vitrification facility is the same as that described in DOE (1979a), except that the costs were escalated from 1976 to 1982 dollars using a factor of 1.71. The facility is designed to produce 
657 canisters ( $1 \mathrm{ft}$ diameter by $8 \mathrm{ft}$ fill height of vitrified HLW). The 1982 facility cost is $\$ 80 \mathrm{million}$ and the annual operating cost is $\$ 10.4$ million.

Two factors were developed to adjust the facility capital cost for changing canister or glass production rates:

1. For increasing canister production rate with a fixed canister size and fill volume, the capital cost was estimated to vary with the 0.6 power of the ratio: Canister production rate/base case production rate. (This is a widely used scaling factor for varying production rates.)

2. The second factor accounts for the increasing glass production rate using a fixed number of larger-diameter canisters. In this situation only a fraction of the facility and equipment increases significantly in size and capacity. It was estimated that about half of the capital cost was substantially affected by glass production rate changes and this would vary as the 0.6 power of the glass production rate. Since the glass volume varies in this case as the square of the canister diameter, this is equivalent to varying the cost as the $0.6 \times 2$ or 1.2 power of the diameter ratios. The following cost relationship results:

$\begin{aligned} & \text { HLW Vitrification } \\ & \text { Facility Cost }\end{aligned} \$ 80 \times 10^{6}\left(\frac{\text { canisters/yr }}{657}\right) \quad\left[0.5 \quad\left[0.5+0.5(\text { D })^{1.2}\right]\right.$

A similar approach was used to develop facility operating costs. Two factors were used to characterize the operating costs:

1. One-third of the base case operating costs, including labor, maintenance, materials and overhead, was estimated to vary with the 0.6 power of the base case canister production rate. The other twothirds of the costs, consisting of process materials and utilities, was estimated to vary linearly with the production rate (about $90 \%$ of the process materials cost is for canisters).

2. The second factor adjusts for the effects of varying the glass production rate. Approximately $30 \%$ of the operating cost is estimated 
to increase only modestly with glass production rate and is assumed to be constant. Sixty percent of the operating cost is estimated to increase as the 0.6 power of the canister volume of the 1.2 power of the canister diameter. The remaining $10 \%$ of the operating cost varies linearly with the production rate or in proportion to the diameter squared to account for the utility and glass-forming materials costs. The following expression for the operating costs results:

$\begin{aligned} & \text { HLW Vitrification } \\ & \text { Operating Cost }\end{aligned}=\$ 10.4 \times 10^{6}\left[1 / 3\left(\frac{\text { canisters/yr }}{657}\right)^{0.6}\right.$

$$
\left.+2 / 3\left(\frac{\text { canisters/yr }}{657}\right)\right] \times\left[0.3+0.6 D^{1.2}+0.1 D^{2}\right]
$$

In the case of the fractionation process waste components, the Cs/Sr waste and the FHLW are vitrified separately. A process flow diagram for the two vitrification processes is shown in Figure 5.2. The same approach was used to develop the cost estimates for these processes as was used for the HLW vitrification facility. However, in this case, the base capital and operating costs were adjusted to reflect the operation of two parallel processes in the same facility. The parallel processes used some common equipment for canister handling and effluent treatment and thus have somewhat lower costs individually. The following cost relationships that apply to either the FHLW or the Cs/Sr waste resulted. The total 1982 facility costs are the sum for both the FHLW and the $\mathrm{Cs} / \mathrm{Sr}$ wastes.

$\begin{aligned} & \text { FHLW or Cs/Sr } \\ & \text { Vitrification }\end{aligned}=\$ 48 \times 10^{6}\left(\frac{\text { canisters/yr }}{657}\right)^{0.6}\left[0.5+0.5(D)^{1.2}\right]$ Facility Cost

FHLW or Cs/Sr $=\$ 9.2 \times 10^{6}\left[1 / 3\left(\frac{\text { canister/yr }}{657}\right)^{0.6}+2 / 3\left(\frac{\text { canister/yr }}{657}\right)\right]$ Operating Cost

$$
x\left[0.3+0.6 D^{1.2}+0.1 D^{2}\right]
$$




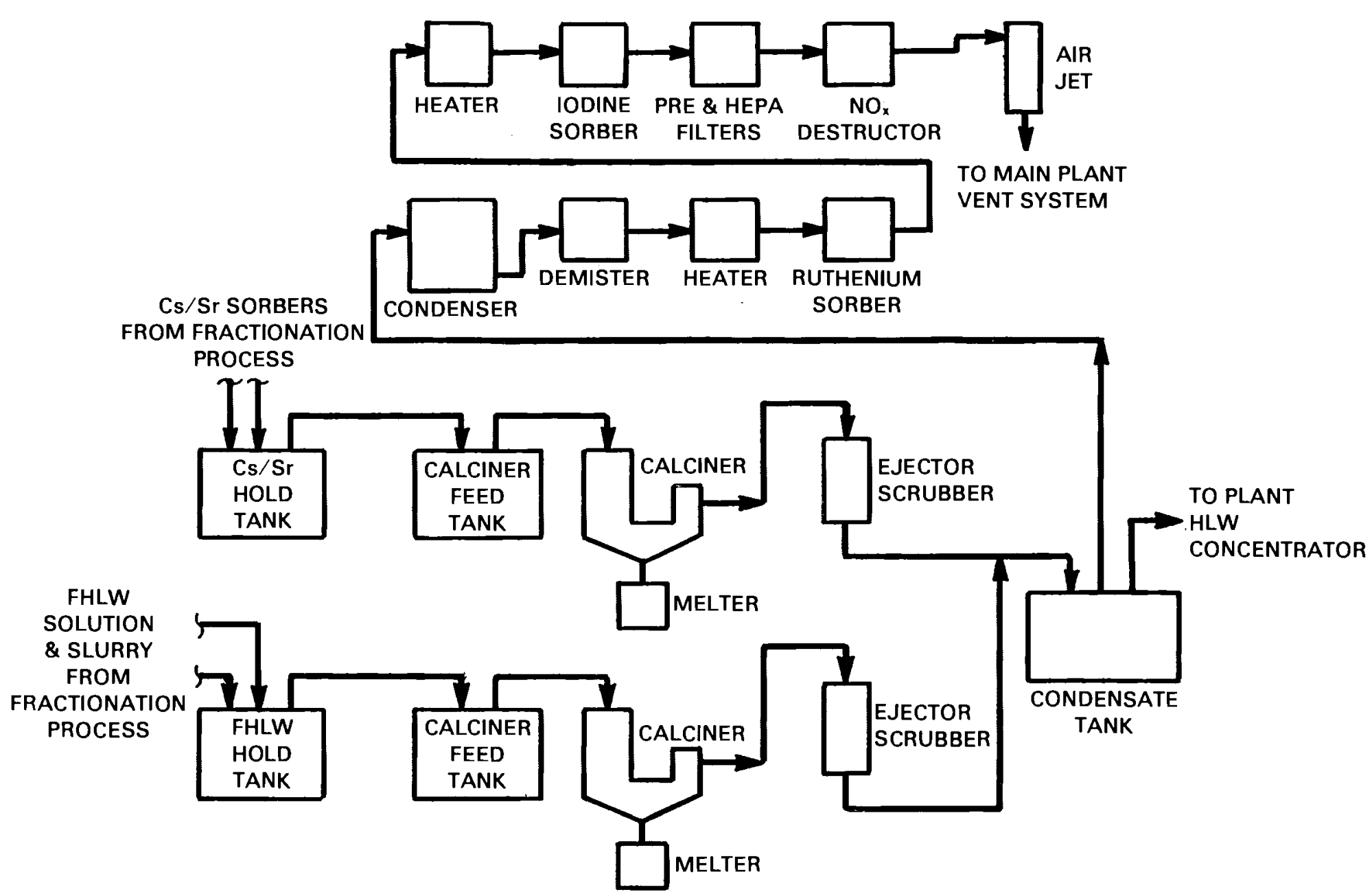

FIGURE 5.2. Vitrification Process Equipment Flow Diagram 
Total annual costs were obtained using a fixed charge rate of $25 \%$ to obtain annual capital charges. Vitrification costs per canisters were then calculated over a range of canister loading in terms of MTE per canister for each of the four canister sizes evaluated in this study. The resulting HLW vitrification costs are shown in Figure 5.3, and the FHLW and Cs/Sr vitrification costs are shown in Figure 5.4. The plots in these figures show how the estimated vitrification costs increase with increasing canister loading in terms of MTE per canister and with increasing canister size at specific MTE loadings. As the MTE per canister increases, the number of canisters produced per 2000 MTE declines; the total annual costs decline as the number of canisters produced declines, but not in proportion to the reduction in annual production rate of canisters. The net result is increasing cost per canister with increasing canister loading, but with the rate of increase gradually tapering off.

These vitrification cost estimates are applicable to vitrification facilities included in the original reprocessing plant construction. For vitrification facilities added after the main reprocessing facility has already been completed, as would be the case in the AGNS plant, the cost for adding these facilities would be very much greater. Taking into consideration the lower processing capability of the AGNS plant, now estimated at 1200 MTHM per year, the vitrification costs would be an even more important factor in the overall system cost comparisons.

\subsubsection{High-Level Waste Transportation Costs}

HLW transport costs were estimated based on the assumptions of $100 \%$ rail shipments and a one-way shipping distance of 1500 miles. To calculate transportation costs, reference shipping systems (shipping casks, transport vehicles, and canisters) must be defined. Four sizes of stainless steel canisters and three heat loadings for each canister size were used for this analysis. Table 5.2 shows these canister sizes, their heat loadings, and the important parameters required for transportation cost calculations. Costs for intermediate sizes and loadings were obtained by interpolation.

Shipping systems for transporting solidified HLW have been designed but none have yet been built. The conceptual shipping cask for rail shipments in this study is described in Peterson and Rhoads (1978). 


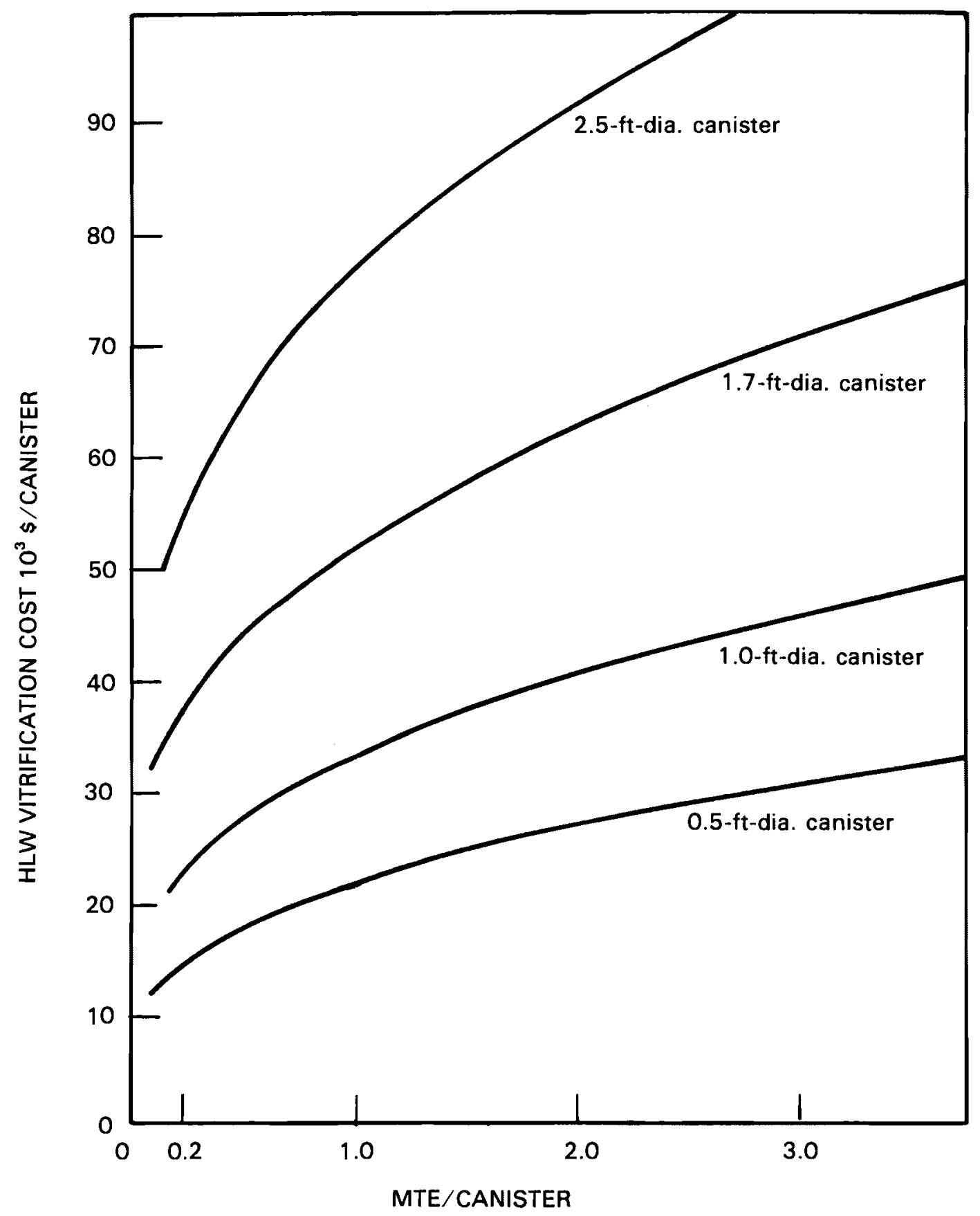

FIGURE 5.3. HLW Vitrification Costs 


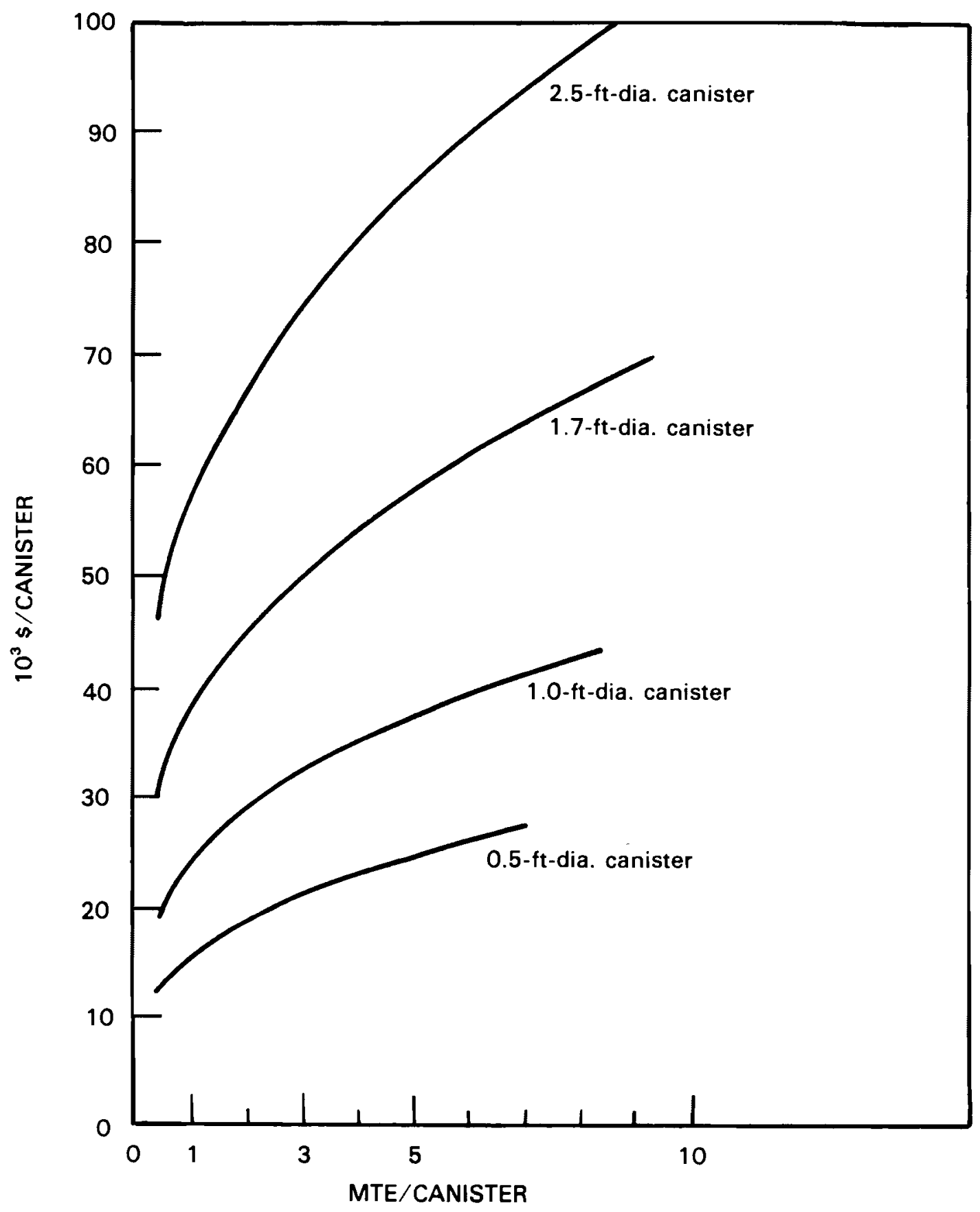

FIGURE 5.4. FHLW and Cs/Sr Vitrification Costs 
TABLE 5.2. Reference HLW Canisters and Shipping Parameters

\begin{tabular}{|c|c|c|c|c|}
\hline Dimensions $(\mathrm{ft})$ & \begin{tabular}{l}
\multicolumn{1}{c}{ Heat } \\
Generation \\
Rate (kW) \\
\end{tabular} & $\begin{array}{l}\text { Glass } \\
\text { Volume } \\
\left(\mathrm{ft}^{3}\right)(\mathrm{a}) \\
\end{array}$ & $\begin{array}{r}\text { Net } \\
\text { Glass } \\
\text { Weight } \\
(\mathrm{Kg})(\mathrm{b}) \\
\end{array}$ & $\begin{array}{c}\text { Loaded } \\
\text { Canister } \\
\text { Weight (kg) (c) }\end{array}$ \\
\hline $\begin{aligned} 0.5 \mathrm{ft} \text { dia } & \times 10 \mathrm{ft} \\
& 1.0 \\
& 2.0\end{aligned}$ & 0.2 & 1.57 & 140 & 200 \\
\hline $\begin{aligned} 1.0 \mathrm{ft} \text { dia } & \times 10 \mathrm{ft} \\
& 1.5 \\
& 3.0\end{aligned}$ & 0.2 & 6.28 & 550 & 790 \\
\hline $\begin{aligned} 1.7 \mathrm{ft} \text { dia } & \times 10 \mathrm{ft} \\
& 2.0 \\
& 4.0\end{aligned}$ & 0.2 & 18.1 & 1600 & 2170 \\
\hline $\begin{aligned} 2.5 \mathrm{ft} \text { dia } & \times 10 \mathrm{ft} \\
& 2.5 \\
& 5.0\end{aligned}$ & 0.2 & 39.33 & 3440 & 4600 \\
\hline
\end{tabular}

(a) Assumes $80 \%$ full canister.

(b) Average bulk density of solidified HLW glass is assumed to be $3.1 \mathrm{~g} / \mathrm{cc}$ (S1ate et al. 1981).

(c) Calculated by ratioing from weight of loaded $0.30-m-d i a$. canister reported in Slate et a1. (1981).

The reference rail cask is a lead-filed, double-walled, stainless steel cylinder with a finned external surface for heat rejection and impact protection. External dimensions (including cooling fins and impact limiters) are $2.5 \mathrm{~m}(8.2 \mathrm{ft})$ in diameter and $4.4 \mathrm{~m}(14.4 \mathrm{ft})$ in length. The internal cavity is $1.5 \mathrm{~m}(4.9 \mathrm{ft})$ in diameter and $3.3 \mathrm{~m}(10.8 \mathrm{ft})$ long. The maximum design heat load this cask can accommodate is $50 \mathrm{~kW}$. Heat rejection is accomplished by passive means, i.e., natural convection, conduction, and radiation of heat through the cask body and to the atmosphere. Canisters are shipped in an airfilled cavity, i.e., no water coolant is used. Gamma shielding is provided by lead in the cask body and depleted uranium (DU) in the lid and closed end. Neutron shielding is provided by a water jacket surrounding the cask body that contains borated water. An aluminum insert fits into the internal cask cavity 
to secure the canisters in place during transport and to aid heat transfer. By changing the aluminum insert, the cask can accommodate different numbers of the four sizes of canisters. The cask is transported on a six-axle rail car equipped with tie-down equipment.

The gamma shield thickness of the reference rail cask was modified to evaluate the cost differences for transporting the various canisters. The reference cask includes a 20-cm (7.9-in.) thick lead shield for the cask body and $12.7 \mathrm{~cm}$ (5 $\mathrm{in.}$ ) of DU shielding at each end. For the purposes of this study, it is assumed that the total heat load on the cask is proportional to the dose rate of the cargo. This makes it possible to calculate the reduction in lead and DU shielding thicknesses and corresponding reductions in cask weights for the various cargo configurations. For example, nine 1-ft-diameter canisters will fit into the cask cavity. If each canister generates $0.2 \mathrm{~kW}$ of heat, the total heat load is only $1.8 \mathrm{~kW}$, or roughly $4 \%$ of the design heat load. Assuming the exposure rate is also $4 \%$ of the exposure rate produced by a 50-kW cargo, the lead and DU shielding thicknesses can be reduced by a gamma attenuation factor of 0.04 . The weight of the cask is then reduced by calculating the weight of the excess lead and DU shielding and subtracting this value from the reference cask weight. The important rail cask characteristics and shipping parameters as conceptually modified are summarized in Table c..1 in Appendix $\mathrm{C}$ of Volume 2.

Transportation cost calculations are based on estimated costs for providing these services by private industry. The costs reported are in mid-1982 dollars for an assumed one-way shipping distance of $2400 \mathrm{~km}$ (1500 miles) and include operating costs plus amortization of hardware plus profits, at commercial rates. Thus, transportation costs are calculated according to the following formula:

$\begin{array}{lll}\text { Total } & \text { Round-Trip } \\ \text { Transportation } & =\begin{array}{l}\text { Shipping } \\ \text { Container } \\ \text { Costs }\end{array} \\ \text { Charges } & \begin{array}{l}\text { Leasing } \\ \text { Fees }\end{array}\end{array} \underset{\begin{array}{l}\text { Equipment } \\ \text { and } \\ \text { Security } \\ \text { Costs }\end{array}}{\text { Demurrage }}$


A discussion of the derivation of costs for each of these transportation cost components is provided in Section C.1 of Appendix C.

One additional item that must be defined to calculate these costs is the average transit time for truck and rail shipments. Rail shipments are estimated to travel about 119 miles per day (Daling 1983). The one-way transit time is therefore approximately 13 days. These values are required to calculate the cask leasing fee per shipment which depends on the number of days the cask is in use, both loaded and for the empty return trip.

Table 5.3 contains the total transportation costs for rail HLW shipments for the various canister sizes and heat loads calculated in this study. These results are also plotted in Figure 5.5 to aid in interpolation for intermediate values. The transport costs are indicated to be only moderately influenced by heat load.

TABLE 5.3. Transportation Costs for Rail HLW Shipments with Various Canister Sizes and Heat Loads

\begin{tabular}{|c|c|c|c|c|}
\hline $\begin{array}{l}\text { Canister } \\
\text { Diameter } \\
(\mathrm{ft})(\mathrm{a}) \\
\end{array}$ & $\begin{array}{c}\text { Heat } \\
\text { Loading } \\
\text { (kg/canister) } \\
\end{array}$ & $\begin{array}{c}\text { Cask } \\
\text { Capacity } \\
\text { (canisters) } \\
\end{array}$ & $\begin{array}{c}\text { Dollars } \\
\text { Per } \\
\text { Shipment (b) } \\
\end{array}$ & $\begin{array}{l}\text { Dollars } \\
\text { Per } \\
\text { Canister }\end{array}$ \\
\hline 0.5 & 0.2 & 27 & 163,200 & 6,040 \\
\hline 0.5 & 1.0 & 27 & 174,400 & 6,460 \\
\hline 0.5 & 2.0 & 25 & 178,700 & 7,150 \\
\hline 1.0 & 0.2 & 9 & 161,400 & 17,930 \\
\hline 1.0 & 1.5 & 9 & 172,400 & 19,160 \\
\hline 1.0 & 3.0 & 9 & 174,900 & 19,430 \\
\hline 1.7 & 0.2 & 4 & 157,100 & 39,280 \\
\hline 1.7 & 2.0 & 4 & 170,700 & 42,680 \\
\hline 1.7 & 4.0 & 4 & 172,900 & 43,230 \\
\hline 2.5 & 0.2 & 2 & 157,100 & 78,550 \\
\hline 2.5 & 2.5 & 2 & 164,300 & 82,150 \\
\hline 2.5 & 5.0 & 2 & 170,400 & 85,200 \\
\hline
\end{tabular}

(a) All canisters are $3.1 \mathrm{~m}(10 \mathrm{ft})$ long.

(b) Assumed shipping distance is $2400 \mathrm{~km}$ (1500 miles) one-way. 


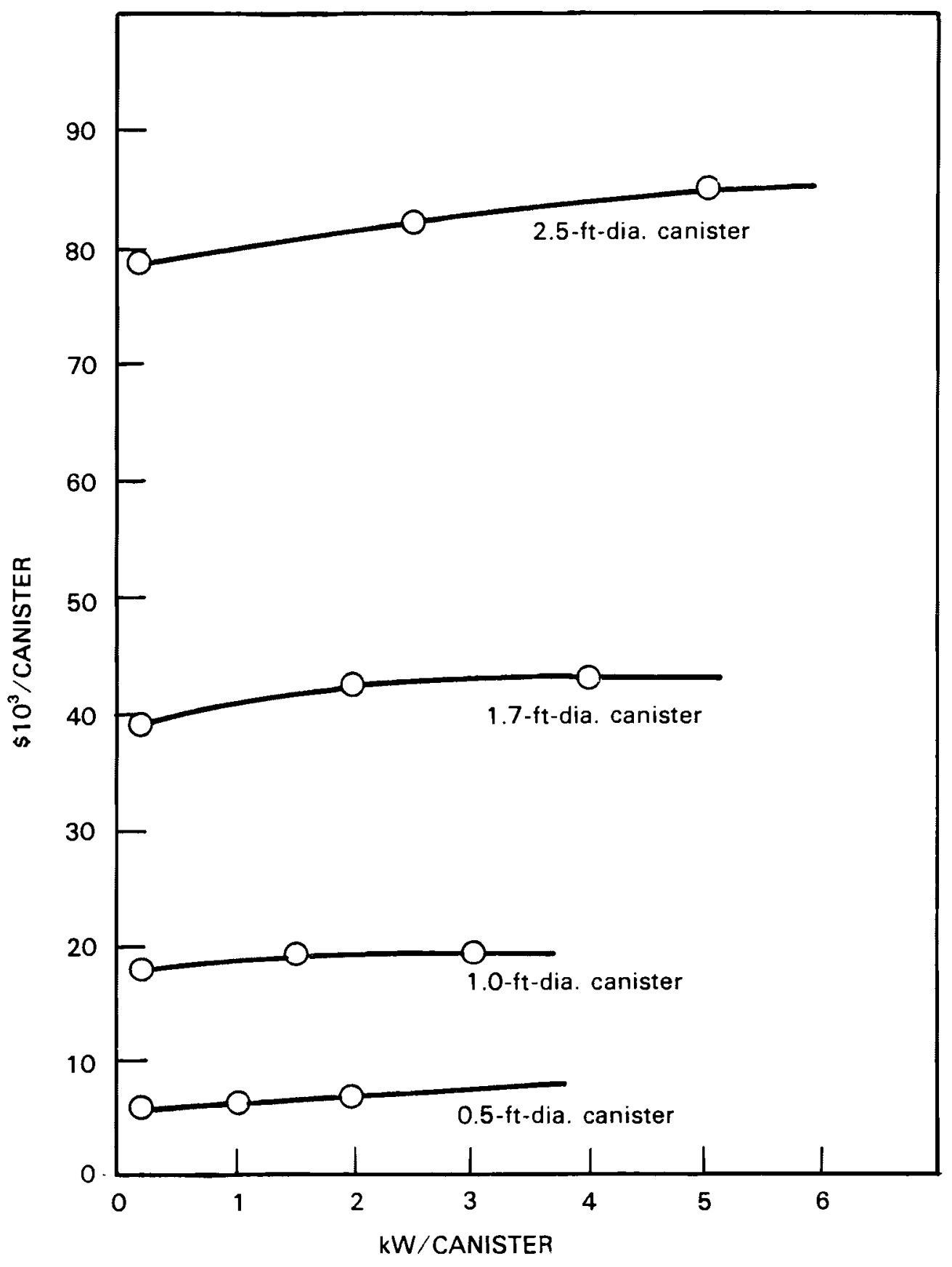

FIGURE 5.5. Rail Transport Costs for HLW, FHLW and $\mathrm{Cs} / \mathrm{Sr}$ Waste 


\subsubsection{Long-Term Storage Costs for HLW and Cs/Sr Waste}

The purpose of long-term interim storage of HLW or its fractionated $\mathrm{Cs} / \mathrm{Sr}$ waste is to permit the ${ }^{137} \mathrm{Cs}$ and ${ }^{90} \mathrm{Sr}$ components (both with $30-\mathrm{yr}$ half-lives) to decay to about one-third of their initial quantities, a storage term of approximately 50 years. The HLW in this case is approximately equivalent to FHLW in terms of heat output.

Two sources of information were used to define the life-cycle costs of this storage. The cost of long-term storage of $1-\mathrm{ft}$-diameter by $10-\mathrm{ft}-1 \mathrm{ong}$ canisters of vitrified HLW in sealed casks was estimated in DOE (1979a), p. 10.A.79, at $\$ 39,200 /$ canister $(1978 \$)$, with each canister holding about 3 MTE (about $3 \mathrm{~kW}$ at 10 years from discharge). Escalation to 1982 costs yields a cost of $\$ 57,400 /$ canister. An estimated cost for 100 -year storage of $1-\mathrm{ft}$ diameter by 10-ft-long canisters of vitrified HLW in an open-field drywell facility was provided in DOE (1981). Total 1981 costs for storing 145,000 MTE of 10-year-old HLW at $3 \mathrm{~kW} / \mathrm{canister}$, or approximately $3 \mathrm{MTE} / \mathrm{canister}$, was estimated at $\$ 3 \times 10^{9}$. This converts to $\$ 68,300 /$ canister when escalated to 1982 dollar values.

These two estimates, from two different sources for two different storage concepts, agree closely. Conservatively, the higher estimate was used to scale storage cost to other size canisters. Storage cost was scaled to other size canisters using the following relationship:

$$
\begin{aligned}
\underset{\text { Canister }}{\text { Storage Cost Per }} & =\left(\begin{array}{c}
\text { Reference Cost } \\
\text { Per Canister }
\end{array}\right) \times\left(\frac{\text { Canister Volume }}{1-f t \text { Diameter }} \begin{array}{c}
\text { Canister Volume } \\
\text { Canter }
\end{array}\right. \\
& =(\text { Reference Cost }) \times(\text { Canister Diameter })^{1.2}
\end{aligned}
$$

The resulting cost relationship is illustrated in Figure 5.6. 


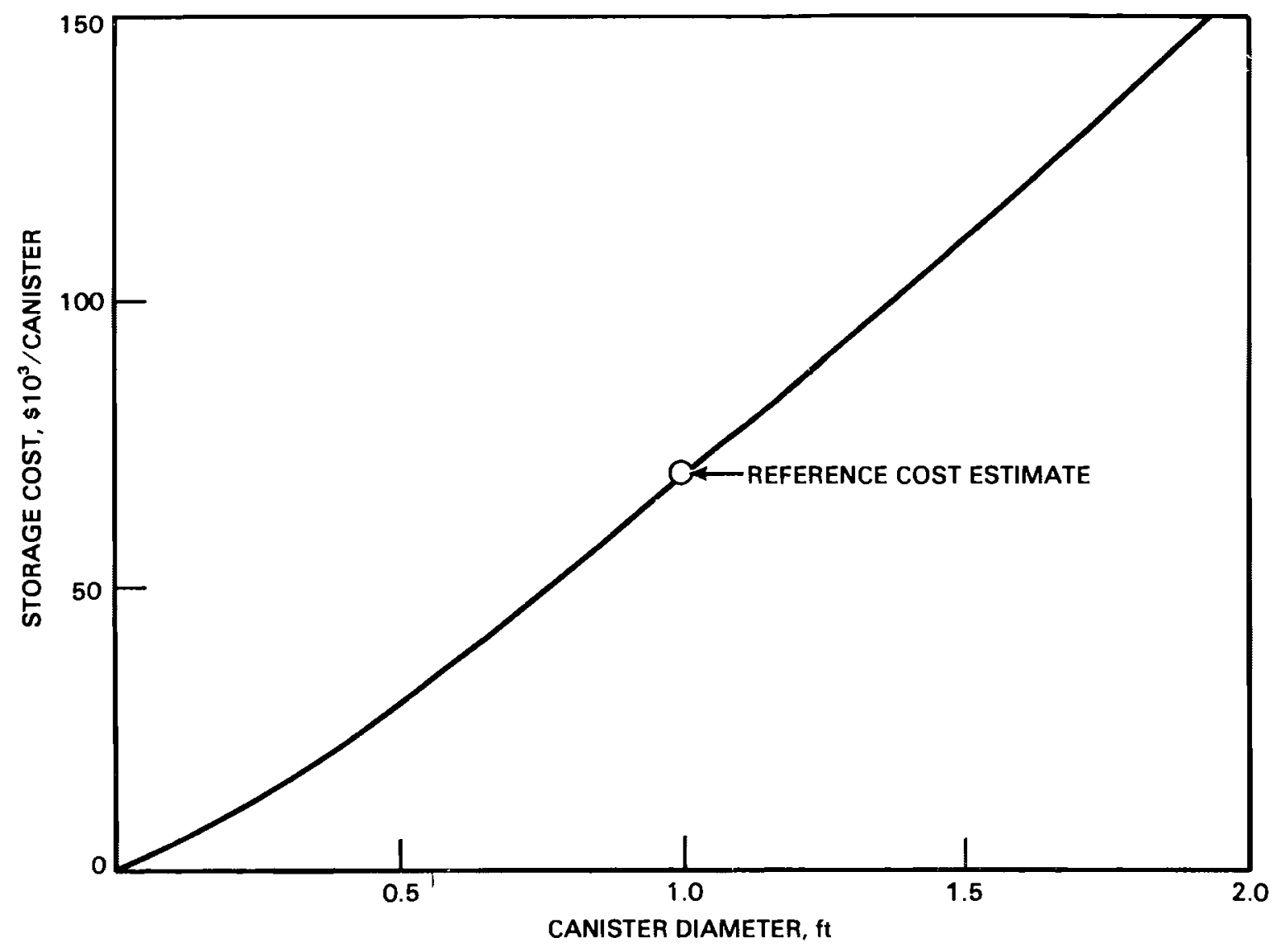

FIGURE 5.6. Estimated HLW Storage Costs

\subsubsection{Geologic Repository Costs}

The computer code RECON was used to develop repository disposal costs for various repository waste loadings defined on the basis of the thermal analysis.

A series of parametric RECON cases was first run using the reference data detailed in this section. The primary variables included:

- canister pitch

- canister heat load

- canister diameter.

The range of values used for the HLW and FHLW cases is shown in Table 5.4, and Table 5.5 shows the values for the $\mathrm{Cs} / \mathrm{Sr}$ waste canisters. The parametric results were used to develop plots of repository costs versus canister heat load (kW/canister) for each of the three waste types. These plots were used in combination with the other system component costs to develop minimum system 
TABLE 5.4. Input Parameters for HLW and FHLW Repository Loading Cases

\begin{tabular}{|c|c|c|c|c|}
\hline \multirow{2}{*}{$\frac{\text { Diameter }(\mathrm{ft})}{0.5}$} & \multirow{2}{*}{$\begin{array}{l}\text { Heat Loading } \\
\text { (kw/can.) }\end{array}$} & \multicolumn{3}{|c|}{ Pitch (m) } \\
\hline & & 2.0 & 3.0 & 6.0 \\
\hline & 0.5 & 2.0 & 3.0 & 6.0 \\
\hline & 1.0 & 2.0 & 3.0 & 6.0 \\
\hline \multirow[t]{4}{*}{1.0} & 0.2 & 2.4 & 4.0 & 7.2 \\
\hline & 0.5 & 2.4 & 4.0 & 7.2 \\
\hline & 1.0 & 2.4 & 4.0 & 7.2 \\
\hline & 1.5 & 2.4 & 4.0 & 7.2 \\
\hline \multirow[t]{4}{*}{1.7} & 0.2 & 2.9 & 4.5 & 8.0 \\
\hline & 0.5 & 2.9 & 4.5 & 8.0 \\
\hline & 1.0 & 2.9 & 4.5 & 8.0 \\
\hline & 2.0 & 2.9 & 4.5 & 8.0 \\
\hline \multirow[t]{4}{*}{2.5} & 0.2 & 3.5 & 5.0 & 8.0 \\
\hline & 0.5 & 3.5 & 5.0 & 8.0 \\
\hline & 1.0 & 3.5 & 5.0 & 8.0 \\
\hline & 2.5 & 3.5 & 5.0 & 8.0 \\
\hline
\end{tabular}

TABLE 5.5. Input Parameters for $\mathrm{Cs} / \mathrm{Sr}$ Waste Canisters

\begin{tabular}{cccccc} 
Diameter (ft) & $\begin{array}{c}\text { Heat Loading } \\
\text { (kW/can.) }\end{array}$ & & \multicolumn{3}{c}{ Pitch (m) } \\
\cline { 2 - 2 } \cline { 5 - 6 } 1.0 & 2.0 & & 2.4 & 4.0 & 7.2 \\
& 2.5 & & 2.4 & 4.0 & 7.2 \\
\multirow{3}{*}{1.7} & 3.0 & & 2.4 & 4.0 & 7.2 \\
& 2.5 & & 2.9 & 4.5 & 8.0 \\
& 3.0 & & 2.9 & 4.5 & 8.0 \\
2.5 & 4.0 & & 2.9 & 4.5 & 8.0 \\
& 3.0 & & 3.5 & 5.0 & 8.0 \\
& 4.0 & & 3.5 & 5.0 & 8.0 \\
& 5.0 & 3.5 & 5.0 & 8.0
\end{tabular}


costs, using procedures described in Section 5.2, after which the specific minimum cost cases were calculated with RECON to provide explicit data for these cases and confirm the results.

The RECON (Repository ECONomics) computer program (Clark 1983) was developed to perform parametric cost studies of mined geologic repositories. Using approximately 200 input design and cost parameters, the model estimates construction and operating costs for repositories. These parameters describe the repository capacity, mine layout, rock excavation and disposal, waste receipt, packaging and emplacement, backfilling, sealing and decommissioning components. Cost functions and data for the variables describing these components have been developed from architect-engineer studies and other published sources. The model develops total costs, unit costs, costs as a function of time, and costs allocated by waste type. A more detailed description of the RECON code is given in Appendix $C$.

The reference repository is a basalt repository, has a 50,000 MTE capacity and is located on a generic site. The repository cost calculations cover a 35-year period, including 8 years for construction and startup. For the reference cases, all repositories use a waste emplacement design consisting of boreholes in tunnel floors. The waste canisters are overpacked at the repository prior to emplacement. The repository design and underground layout are based on information obtained from the Basalt waste Isolation Project (BWIP). The waste package conceptual design is based on the reference design in Westinghouse (1981a). A nominal 5-year demonstration period between emplacement and backfilling of rooms is included in all cases. The costs are calculated for a11 cases in undiscounted 1982 dollars.

Parameters that are not readily identifiable as dependent on waste package design are held constant for each of the reference cases to allow comparisons of repository costs under similar sets of assumptions. Cost data from a number of sources were used as input data for the RECON code. These sources are discussed below. 


\section{Facilities}

Surface facility requirements are derived from DOE (1979a), while basic repository layout, shaft-functions, diameters and capacities are based on BWIP information. Facility construction costs and equipment costs by facility are derived from a number of sources identified in Clark (1983). Equipment life is assumed to be 15 years, except for mining equipment life, which was 8 years. Construction, shaft excavation and preoperational mine excavation schedules are based on Bechtel (1979) estimates. Repository depth is based on Westinghouse (1981a).

\section{$\underline{\text { Receiving and Packaging }}$}

An integral packaging facility at the repository is assumed. The waste handling building on the repository surface consists of a receiving module that has a capacity of about 7500 canisters ( $1 \mathrm{ft} \times 10 \mathrm{ft}$ ) per year and costs $\$ 10.5$ million. The base packaging module costs $\$ 155$ million with a matching capacity. The packaging facility cost estimates are derived from DOE (1979a). The packaging modules are scaled up or down along with the receiving modules.

The RECON model calculates the number of receiving modules required, based on the number of rail casks received and the capacities of the casks. The conceptual rail cask for this study was described in Section 5.1.3. Canisters for HLW and FHLW are over-packed in titanium-clad, carbon-steel canisters as described in Westinghouse (1981a). Costs of the titanium-clad packages were estimated by Westinghouse to be $\$ 9820$ each for the 1-ft-diameter canisters and were scaled linearly with the canister diameter. Canisters for the Cs/Sr waste were overpacked in carbon-steel canisters, with a reference cost of $\$ 2500$ each for a 1-ft-diameter canister.

\section{Canister Receipt Schedule}

The canister receipt schedule for all cases is based on the placement of 50,000 MTE over a 27-year period (35-year period from start of construction to completion of the emplacement). The receipt rate varies with the canister waste loading. 


\section{Mining and Rock Handling}

Mining cost estimates in the model are subdivided into direct mining costs and mining equipment costs. Direct mining costs include all direct costs for labor and materials required to excavate and transport the rock. Also included are costs to drain, ventilate, and develop the tunnel and indirect costs for mining support functions. Costs for direct mining are based on PBQ\&D (1978) cost estimates escalated to 1982 dollars. The direct mining cost estimate used in this analysis is $\$ 18$ per tonne for basalt. For consistency, the mining equipment costs are also based on the report by PBQ\&D (1978) escalated to 1982 dollars. An extraction ratio of 0.183 for basalt is used (Westinghouse 1981a). Extraction ratio is the ratio of emplacement room floor area to total crosssection area of rooms plus the pillars separating the rooms.

Direct hoisting costs are estimated based on data and relationships in Thadani (1980). These data give cost relationships as a function of repository depth. A corresponding estimate for 1,000-meter depths for repositories in basalt is $\$ 0.45$ per tonne.

Backfilling cost estimates are derived from DOE (1979a). These estimates are based on using continuous backfilling machines that pile the backfill into the rooms. An estimate of $\$ 17.40 / \mathrm{m}^{3}$, in 1982 dollars, is developed for basalt.

Surface disposal charges for managing the mined rock on the surface are based on estimates in PBQ\&D (1978) for the hard rock media. Escalated to 1982 dollars, this is $\$ 0.75$ per tonne for basalt.

Data on rock densities for basalt are based on information contained in Brown $(1980)$. The value used in this work is 2.77 tonnes $/ \mathrm{m}^{3}$ for basalt.

\section{Shafts}

Each repository is initially provided with the following shafts: men and materials, canistered waste, confinement air intake, storage exhaust, and a combined development exhaust and mine production shaft. The number of mine production shafts may be increased based on the emplacement rate requirements. Shaft excavation, lining, and water control cost functions used in the model are based on plots derived from PBQ\&D (1978). The cost data are based on conventional drill and blasting excavation techniques. 


\section{Underground Waste Operations}

Cost estimates for the shaft stations underground are based on estimates given in Brown (1980) for the NWTSR2 repository design. Costs of transporters to transfer casks from the shaft stations and emplace them in the boreholes are based on estimates given in Westinghouse (1981a). Underground equipment life is conservatively estimated to be 8 years. Underground labor costs are based on labor requirements specified in Bechtel (1979).

The estimated cost for hole drilling in hard rock media, such as basalt, is $\$ 3,250(1982 \$)$ for a $1-\mathrm{ft}$-diameter canister requiring an approximate 3.2-ftdiameter hole, $15 \mathrm{ft}$ deep. Hole-boring costs are scaled with cross-section area for other sizes.

The reference repository emplacement concept provides for preformed bentonite blocks to be placed in the boreholes. Based on Westinghouse (1981a), a cost of $\$ 3,500$ (1982) per hole for 1-ft-diameter canisters and for bentonite blocks having a 0.23-m thickness is used as the bentonite cost basis in this study and is scaled linearly with thickness and hole diameter. This cost includes both the cost of materials and fabrication.

\section{Emplacement Configurations}

Emplacement configurations are functions of limiting thermal guidelines and rock strengths and these are specified by input data for each calculation. Contingency

A contingency allowance of $20 \%$ is used in all calculations. 


\subsection{SYSTEM COST ANALYSIS}

The analysis methodology and results of the waste management cost analysis are discussed in this section. Cost comparisons of the waste management alternatives are compared on the basis of the entire waste management system, including both the repository requirements and the requirements for waste processing, storage, and transportation prior to delivery to the repository. Comparisons are developed on the basis of a 50,000 MTE system for each alternative.

The three basic alternative disposal systems compared are:

1. A reference concept with disposal of vitrified HLW.

2. The $\mathrm{Cs} / \mathrm{Sr}$ fractionation concept.

3. Storage of HLW prior to disposal, which achieves a reduced heat load through decay rather than fractionation.

Two variations of the fractionation alternative are evaluated, including 1) fractionation of $\mathrm{HLW}$ in a plutonium recycle fuel cycle, which yields an FHLW component at $0.3 \mathrm{~kW} / M T E$, and 2) fractionation of $\mathrm{HLW}$ in a once-through or norecycle fuel cycle, which yields an FHLW component at $0.18 \mathrm{~kW} / \mathrm{MTE}$.

The effect of two alternative HLW compositions, as influenced by the fuel reprocessing flowsheet, is also evaluated. One alternative is based on minimum addition of inert components during the process and yields minimum specific volumes of $1.41 \mathrm{ft}^{3} /$ MTE for HLW and $1.20 \mathrm{ft}^{3} /$ MTE for FHLW. The other alternative is based on the proposed Barnwell reprocessing plant flowsheet (Slate et al. 1981) and yields minimum specific volumes of $3.14 \mathrm{ft}^{3} / \mathrm{MTE}$ for HLW and $2.70 \mathrm{ft}^{3} / \mathrm{MTE}$ for FHLW. For the $\mathrm{Cs} / \mathrm{Sr}$ waste, minimum specific volumes of 1.73 and $2.0 \mathrm{ft}^{3} /$ MTE were evaluated. See Section 4.2 of Chapter 4 for derivation of these quantities.

Comparisons are developed for the HLW and FHLW considering disposal both with and without a bentonite backfill requirement. (The insulating effect of the bentonite backfill constrains the allowable waste canister heat loading.) The analysis centers on waste package temperature limits. For the bentonite backfill cases, comparisons are developed for maximum bentonite temperatures of 
$100^{\circ}, 150^{\circ}, 200^{\circ}$, and $250^{\circ} \mathrm{C}$. For the comparisons without bentonite backfil1, comparisons are developed on the basis of maximum waste centerline temperatures of $100^{\circ}, 200^{\circ}, 300^{\circ}$ and $400^{\circ} \mathrm{C}$. For the Cs/Sr waste, emplacement without bentonite backfill was the only concept evaluated, with emplacement limits based on maximum basalt temperatures of $300^{\circ}, 350^{\circ}$, and $400^{\circ} \mathrm{C}$. The costs for disposal of the Cs/Sr waste in the same repository with the FHLW are based on a maximum basalt temperature of $300^{\circ} \mathrm{C}$.

The repository area requirements varied over a wide range. To determine the cost impact of a fixed repository size on the comparison of alternatives, the 50,000 MTE system costs were also determined for repositories limited to a 1600-acre size. For large emplacement area requirements, multiple repositories are required and for small emplacement area requirements, the repository can be shared with additional waste. The waste receiving rates were set equal to the receiving rates for the 50,000 MTE repository, with repositories assumed to be operated sequentially. The smaller repositories have proportionally larger initial construction costs, but operate for a shorter time, which tends to reduce the cumulative total of fixed operating costs. These two factors tend to compensate for each other and the 1600-acre repository limit did not have a particularly strong effect on total system cost estimates.

\subsubsection{Cost Analysis Methodology}

Minimum costs for each alternative were developed from considerations of three primary variables: canister size, waste concentration, and canister spacing (or pitch) in the repository. Canister size was varied by varying the canister diameter with a fixed 10-ft length and an $80 \%$ fill height. For each of four canister diameters, three waste-concentration canister-pitch combinations were selected from the thermal analysis results that yielded a specified maximum bentonite or waste centerline temperature. For this purpose, waste concentration was expressed in terms of kilowatts per canister heat loading. Vitrification, transportation, and waste storage costs, in the case of the storage alternatives, were then determined for each of these three conditions. The minimum system cost was then determined from a plot of total costs versus canister pitch for each of the four canister sizes. The four canister sizes included diameters of $0.5 \mathrm{ft}, 1.0 \mathrm{ft}, 1.7 \mathrm{ft}$, and $2.5 \mathrm{ft}$. 
Figure 5.7 provides an example of an optimization for a 1-ft-diameter HLW waste canister and a $200^{\circ} \mathrm{C}$ maximum bentonite temperature. To aid in understanding the relationships involved here, two additional abscissa scales are provided. These are the kilowatt per canister loading and the waste volume as cubic feet/MTE. To maintain the $200^{\circ} \mathrm{C}$ maximum bentonite temperature as the canister pitch increases, the canister loading increases. This is accomplished by increasing the waste concentration in the glass, which is reflected in the declining waste volume shown on the bottom scale of Figure 5.7. Since the canister size is fixed, the waste volume variations are accommodated by adjusting the number of canisters required to dispose of 50,000 MTE. Increasing numbers of canisters are required as the canister pitch is reduced, which tends to increase repository costs. As the canister pitch is increased, repository costs pass through a minimum and tend to increase because the increasing mined volume requirement increases costs more rapidly than the reduction in the number of required canisters reduces costs. Vitrification and transportation costs both decline as the canister pitch is increased because fewer canisters are required. Adding up the repository, vitrification, and transportation costs yields the total system costs. The minimum point on the system cost is shifted to the right relative to the repository minimum costs because of the influence of the vitrification and transportation costs. The kilowatt per canister loading at both the repository and system cost minimums is indicated in Figure 5.7 .

Using the same $200^{\circ} \mathrm{C}$ maximum bentonite temperature as in the previous example, an example showing the effect of canister diameter on repository and system costs for HLW disposal is presented in Figure 5.8. This shows repository costs to be relatively insensitive to canister size, but total system costs decline sharply with reduced canister sizes. This trend was found in all of the cases evaluated in this study. To aid in understanding this trend, the same two additional scales are shown on the abscissa as in the previous figure. This shows that although the canister waste loading increases with increasing canister size it does not increase nearly in proportion to the increase in waste volume. The waste volume increases both vitrification and transportation costs and results in the higher costs for larger canisters. 


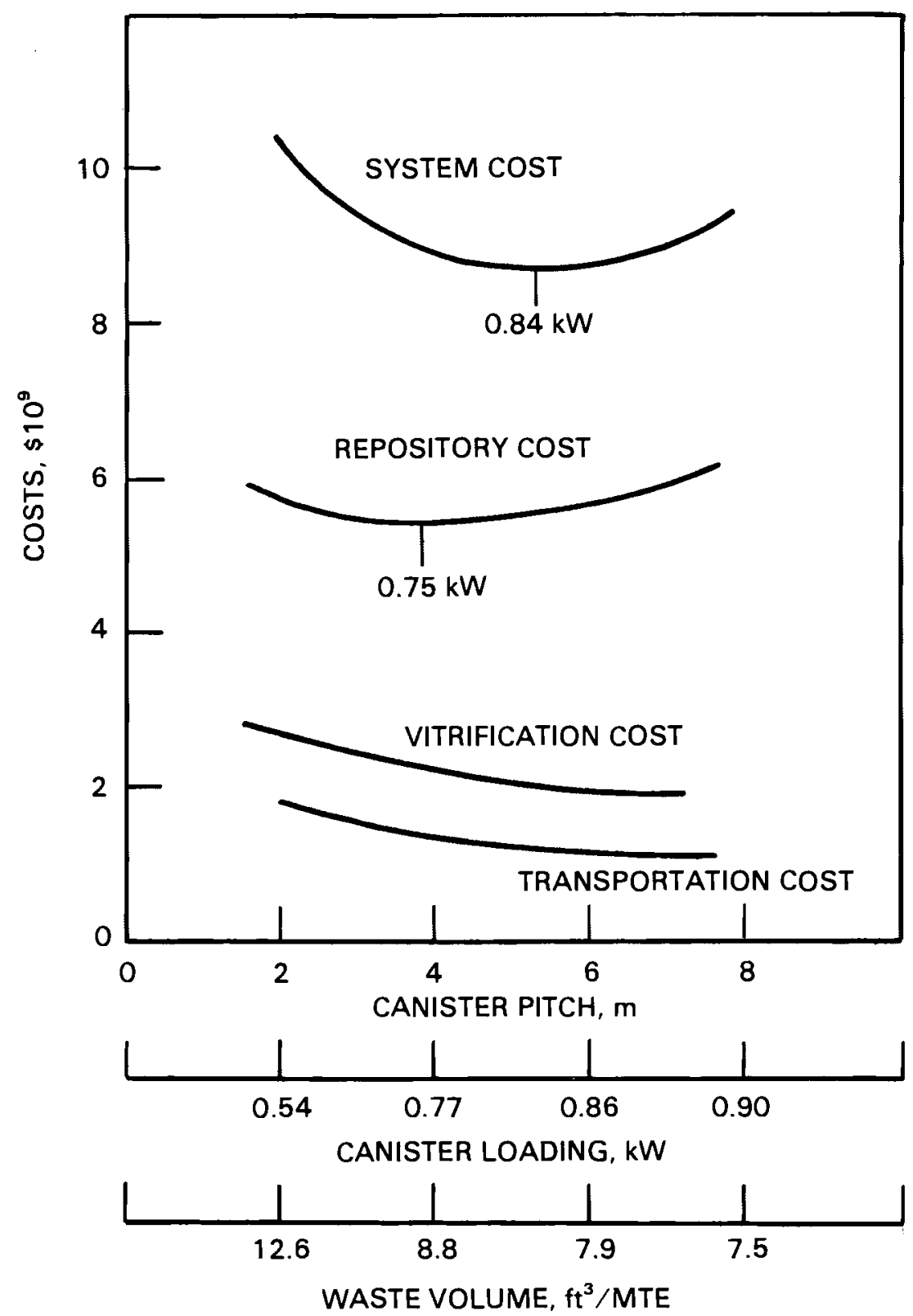

FIGURE 5.7. Example of a Disposal System Optimization with a Fixed Canister Size

HLW in 1-Foot-Diameter Canisters $200^{\circ} \mathrm{C}$ Maximum Bentonite Temperature

50,000 MTE System 


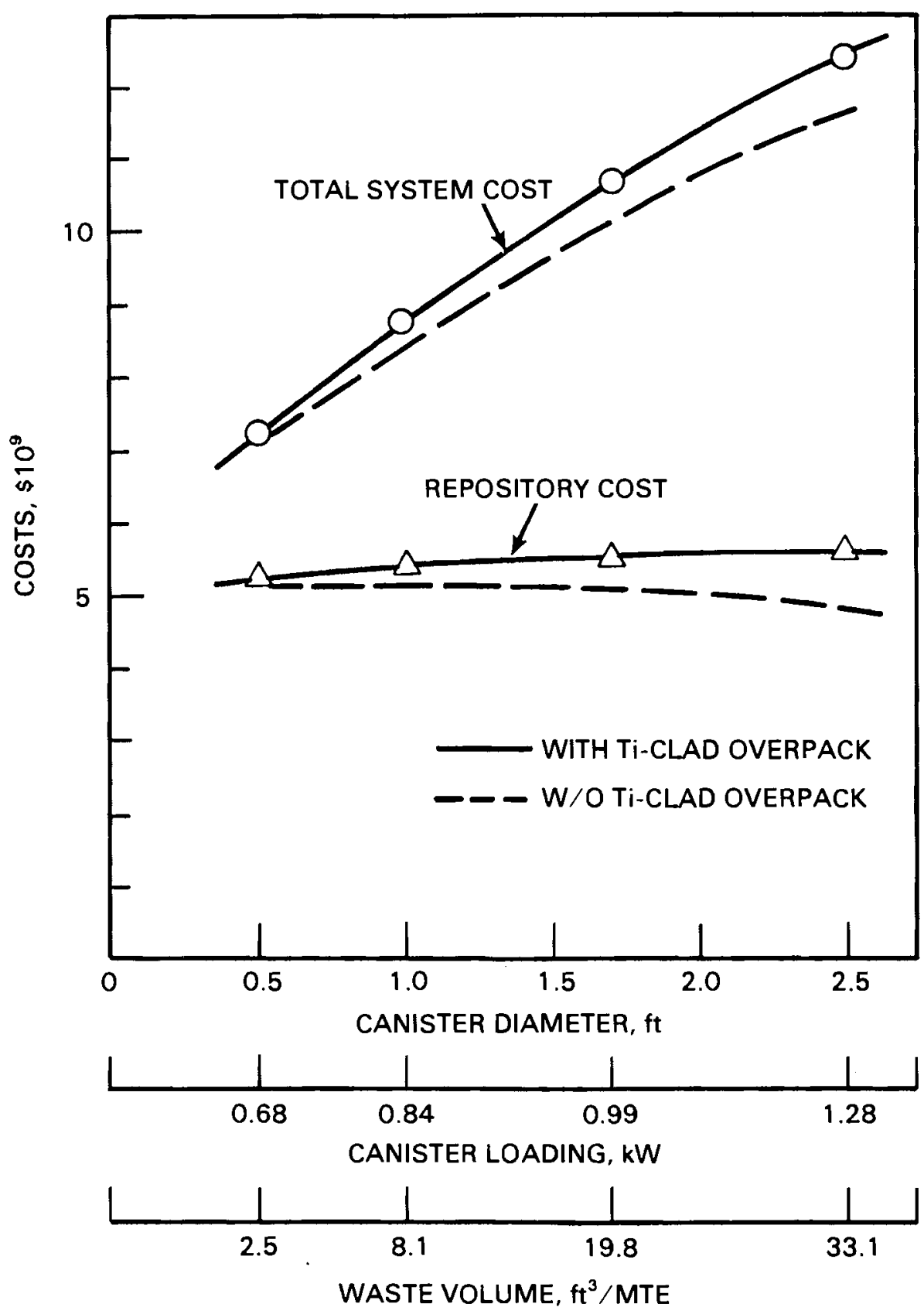

FIGURE 5.8. Example Showing Declining System Costs as Canister Size is Reduced

$200^{\circ} \mathrm{C}$ Maximum Bentonite Temperature

50,000 MTE Systein 
The impact of a costly overpack material, in this case a 0.1-in.-titanium cladding, is also illustrated in Figure 5.8. The impact of the titanium cladding is shown to be relatively small at the smaller canister sizes.

Only the optimum or minimum cost results are presented and discussed in this section. The results of the calculations that led to determination of these minimum cost results are presented in a series of tables in Section $C .3$ of Appendix C.

A plot of total system costs versus canister diameter for HLW disposal at each of the four maximum bentonite temperatures that were evaluated is shown in Figure 5.9. Similar plots for the FHLW for both the recycle and no-recycle fuel cycle cases are shown in Figures 5.10 and 5.11, respectively. A plot of total system costs for HLW aged to the same heat output level as the FHLW recycle case is shown in Figure 5.12. The Cs/Sr waste component was emplaced without a bentonite backfill and was assumed to be limited by the maximum basalt temperature. A plot of $\mathrm{Cs} / \mathrm{Sr}$ waste system cost versus canister diameter for maximum basalt temperatures of $300^{\circ}, 350^{\circ}$, and $400^{\circ} \mathrm{C}$ is shown in Figure 5.13 .

The preceding results consistently show that, from a cost standpoint, small-size canisters are desirable. For this study, the canister size was limited to the larger of either a 0.5-ft-diameter canister or the canister size determined by the maximum achievable waste concentration. Canister sizes smaller than $0.5 \mathrm{ft}$ in diameter may be feasible, but all of the cost relationships used in this study were developed based on a minimum canister size of $0.5 \mathrm{ft}$ diameter, and the correlations may not be valid when extrapolated to smaller sizes. In addition, the cost reductions achievable by extrapolation of results to canister sizes smaller than 0.5-ft-diameter were indicated to be relatively small.

To determine the minimum canister size as limited by waste concentration, the minimum-cost canister heat load was plotted against canister diameter as shown in Figure 5.14 for HLW. This figure shows four bentonite temperature isotherm plots of minimum-cost canister heat loads versus canister diameter. Also plotted are maximum canister loadings at the alternative minimum waste volumes of 1.41 and $3.14 \mathrm{ft}^{3} /$ MTE. The intersections of these curves represent the optimum configuration. The optimum configuration is the minimum achievable canister size with a canister loading at maximum concentration (i.e., minimum volume) that lies on the minimum system cost 


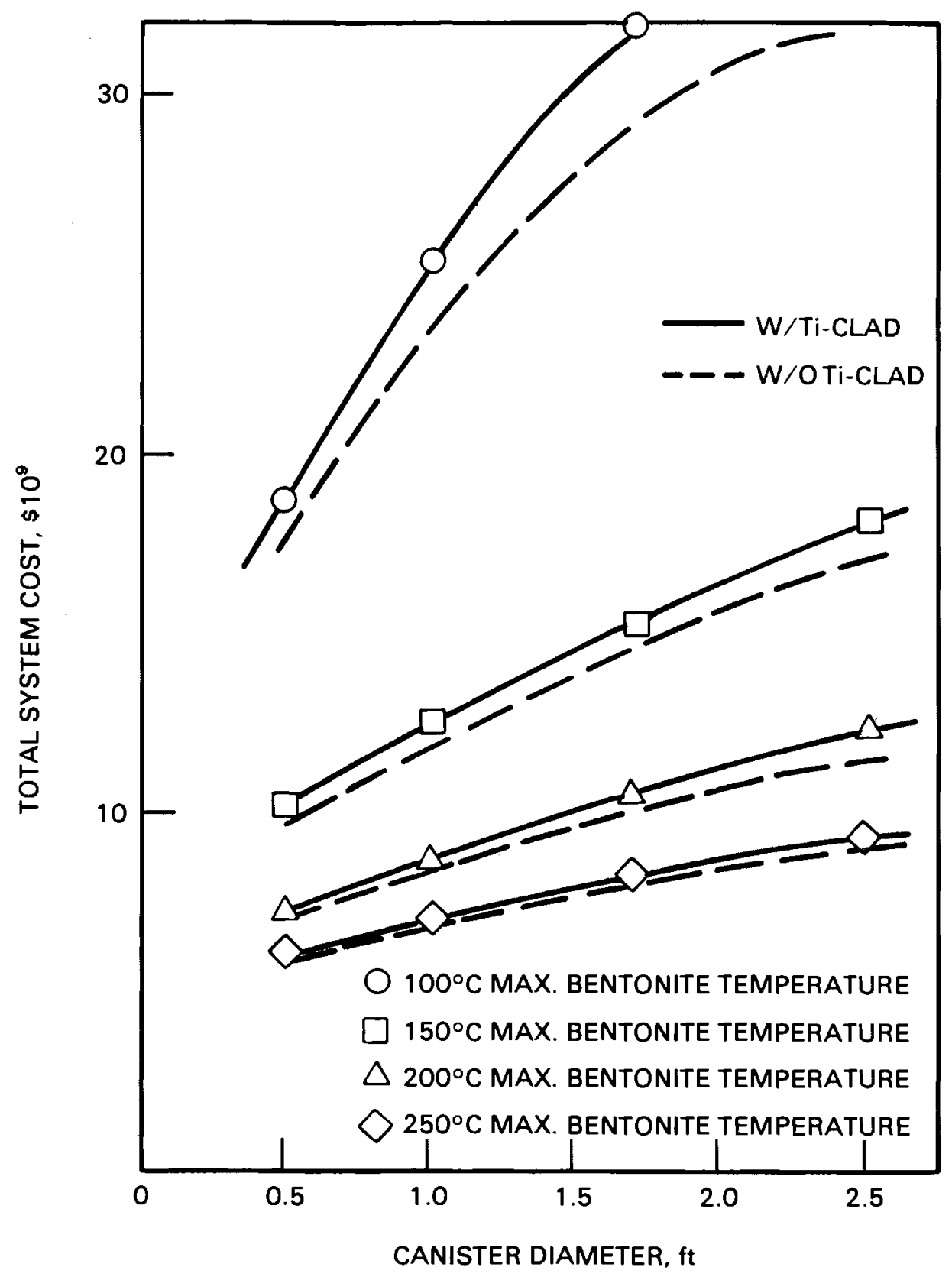

FIGURE 5.9. Minimum Total System Costs for HLW Over a Range of Canister Sizes and Maximum Bentonite Temperatures 


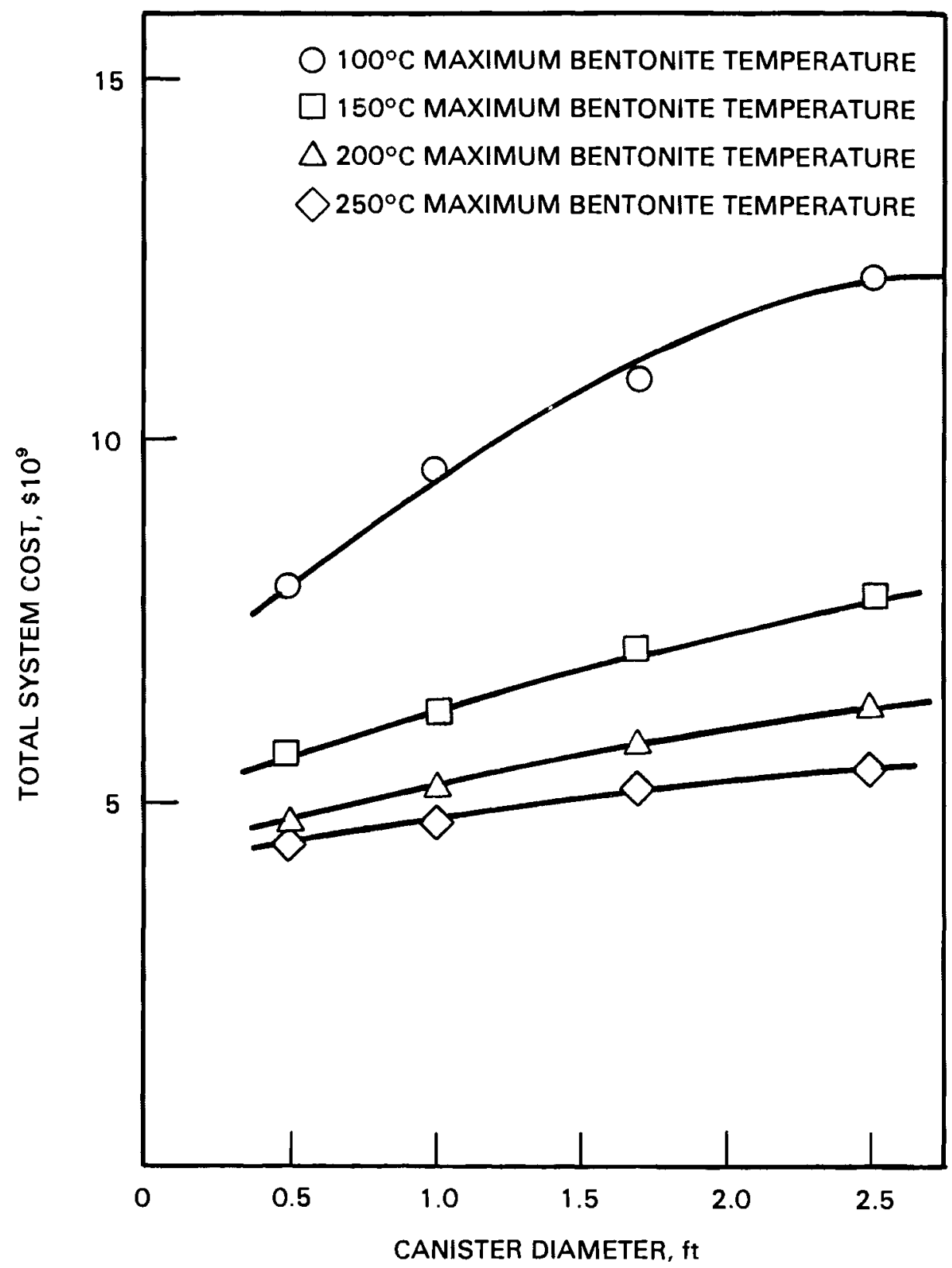

FIGURE 5.10. Minimum Total System Costs for FHLW Recycle Case Over a Range of Canister Sizes and Maximum Bentonite Temperatures 


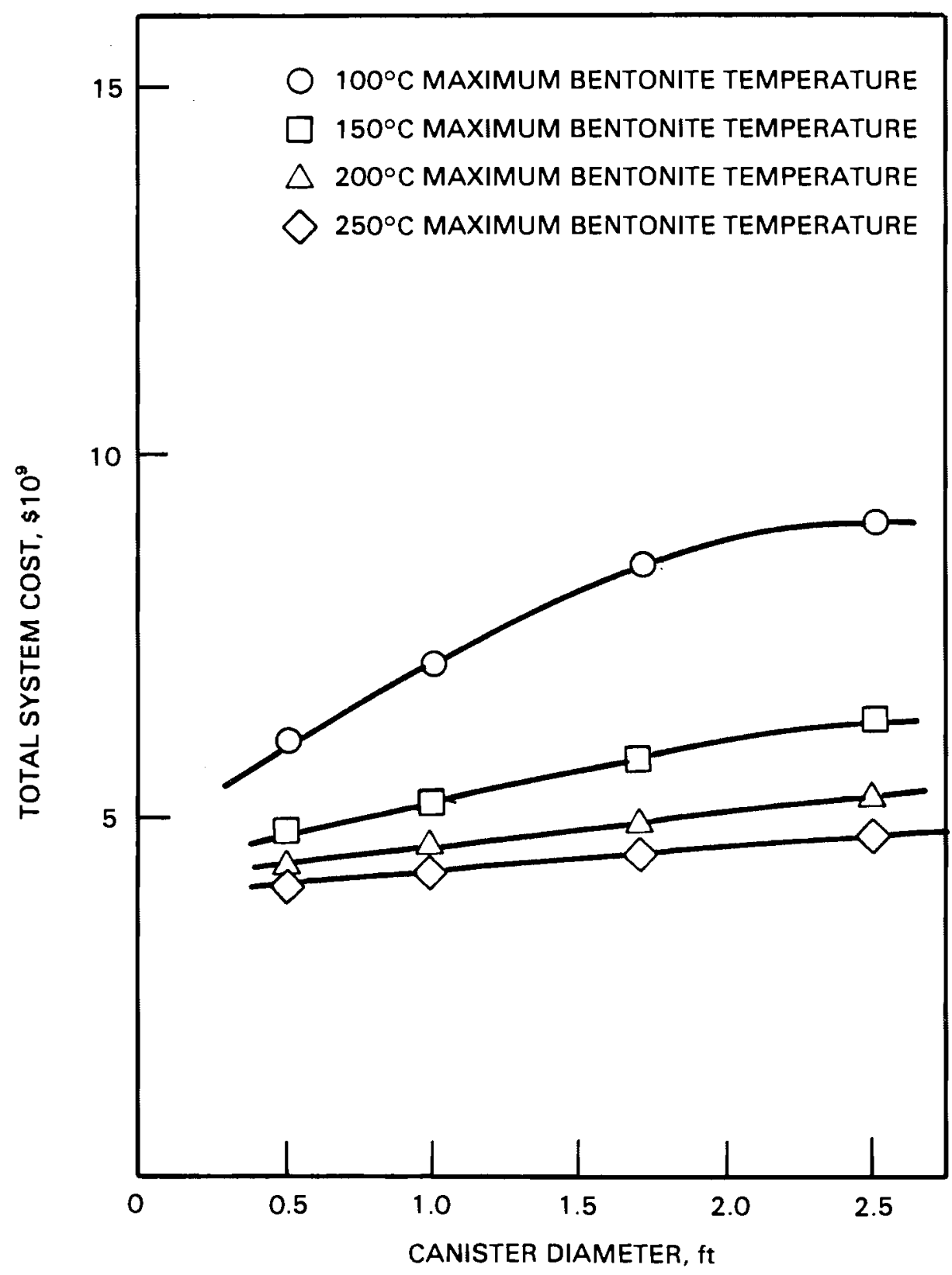

FIGURE 5.11. Minimum Total System Costs for FHLW No-Recycle Case Over a Range of Canister Sizes and Maximum Bentonite Temperatures 


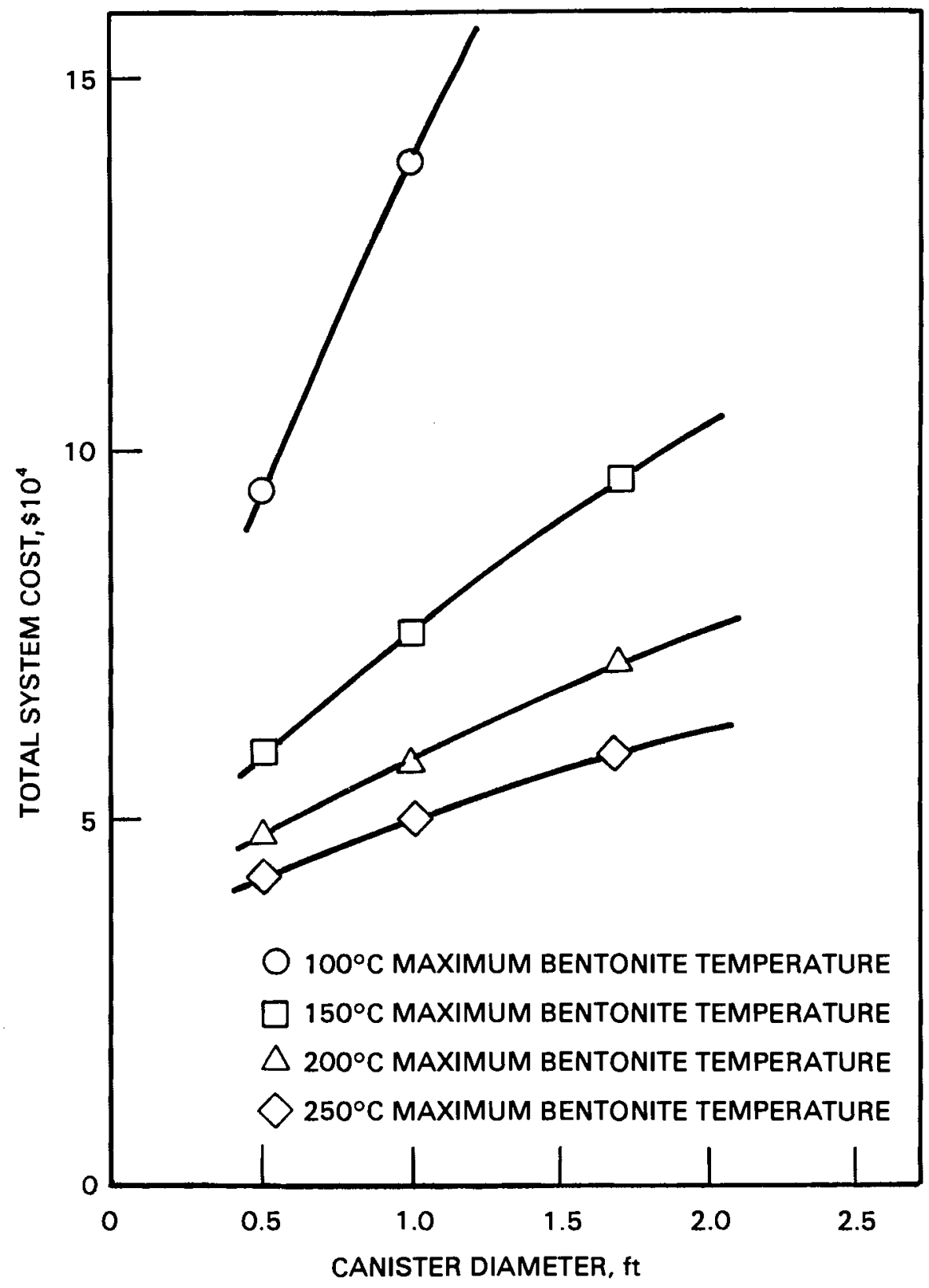

FIGURE 5.12. Minimum Total System Costs for Aged-HLW Over a Range of Canister Sizes and Maximum Bentonite Temperatures 


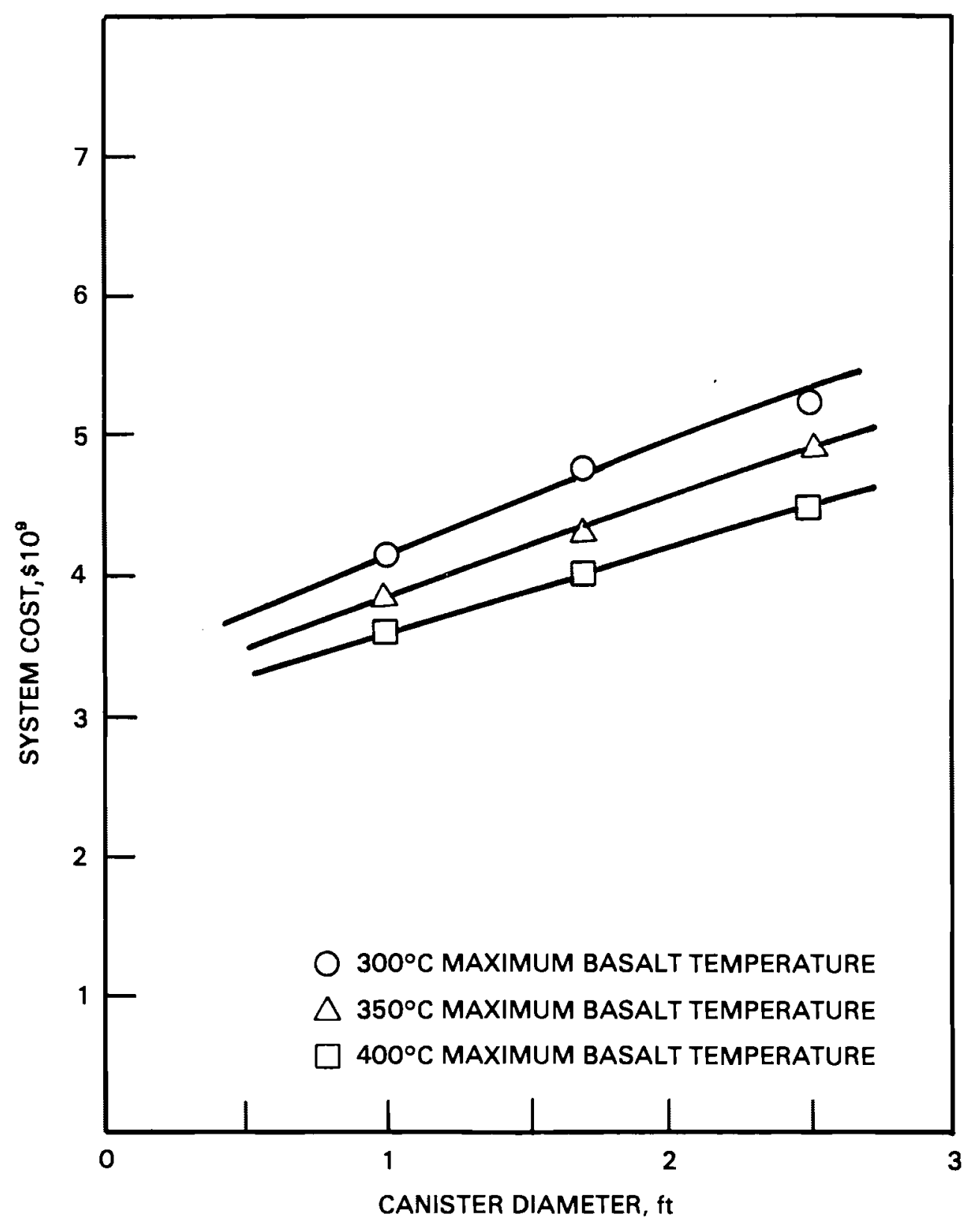

FIGURE 5.13. Minimum Total System Costs for Cs/Sr Waste 


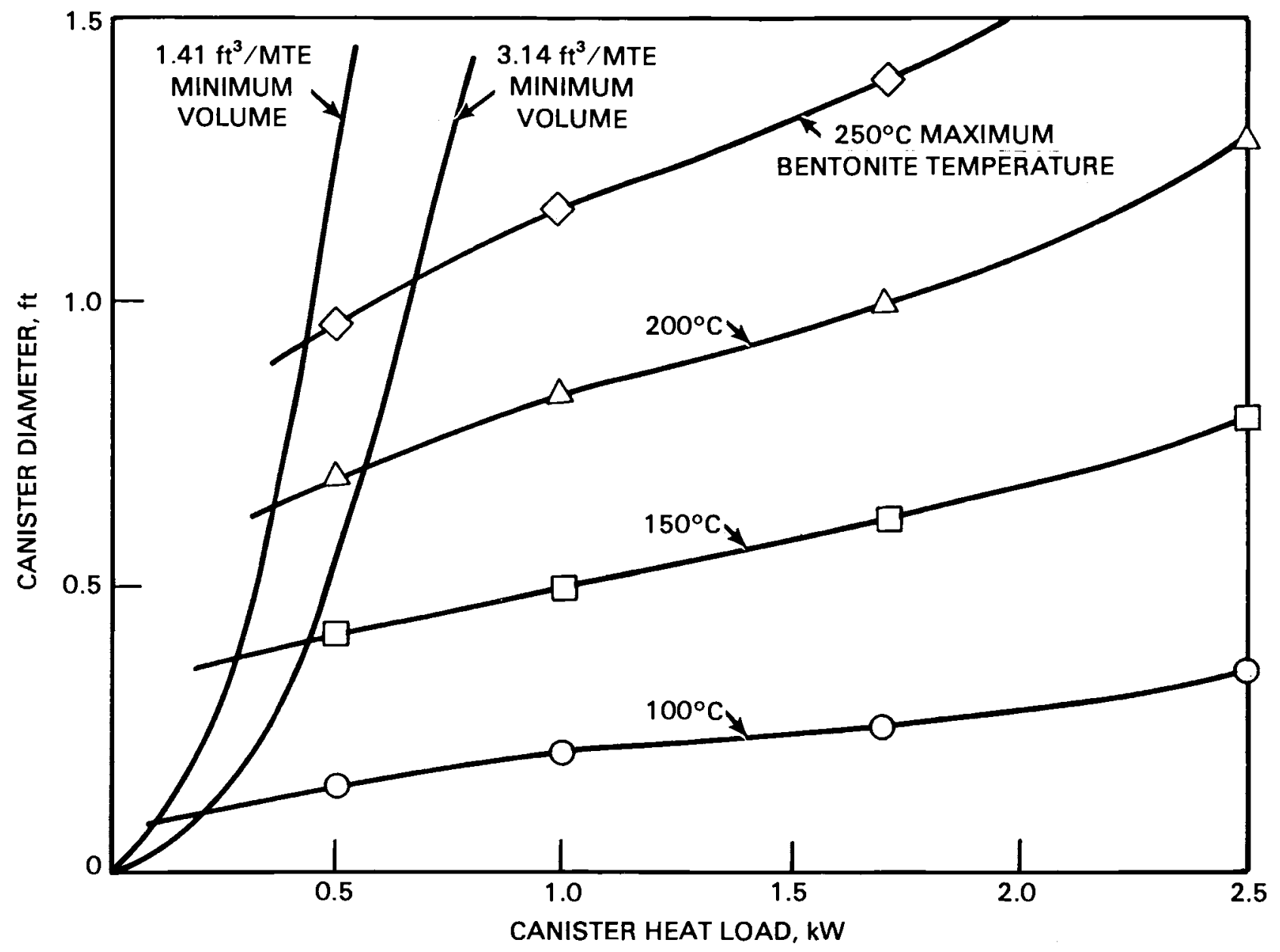

FIGURE 5.14. Optimum Canister Heat Loading Determination for HLW 
curves shown in Figure 5.9. The comparable plots of canister heat load versus canister diameter for the FHLW recycle case and the FHLW no-recycle case are shown in Figures 5.15 and 5.16, respectively. The heat load versus canister diameter plot for the aged-HLW is shown in Figure 5.17, and for the Cs/Sr waste in Figure 5.18. The bentonite temperature isotherms are similar for all of the HLW and FHLW plots, but the minimum volume intersections are quite different.

\subsubsection{Minimum Cost Comparisons with Bentonite Backfill}

A summary comparison of total costs for HLW and FHLW disposal with the bentunite backfill is provided in Table 5.6. The FHLW disposal cases include the requirements for disposal of the $\mathrm{Cs} / \mathrm{Sr}$ waste component in a separate section of the same repository. To provide a common reference for comparison with the cases presented later without the bentonite backfill, the approximate maximum waste centerline temperature is also shown. The waste centerline temperature is not necessarily identical for all alternatives at a fixed maximum bentonite temperature. However, the variation is generally within about $\pm 5^{\circ} \mathrm{C}$. To provide additional perspective, the system costs are also plotted in Figure 5.19. Scales are also provided in this figure for both maximum waste centerline temperature and maximum bentonite temperature.

At higher bentonite temperatures, the cost ranges for the FHLW and HLW disposal alteriatives overlap, indicating no advantage for the fractionation concept. However, as the bentonite temperature or waste centerline temperature is reduced, the fractionation concept begins to show a significant cost advantage. At the $100^{\circ} \mathrm{C}$ bentonite temperature, the FHLW system costs are approximately one-half of the HLW system costs. The fractionation costs increase only very slowly as the bentonite temperature is reduced from $250^{\circ} \mathrm{C}$ to about $150^{\circ} \mathrm{C}$, at which point the costs increase more steeply. This indicates that substantial temperature reductions could be realized with the fractionation concept at a relatively small increase in total system costs.

The 1600-acre repository cases show higher costs than the singlerepository cases but, except for the HLW case, the differences are relatively small. The differences between the low and high specific waste volume alternatives are also relatively small, indicating that the results are not extremely sensitive to this parameter. 


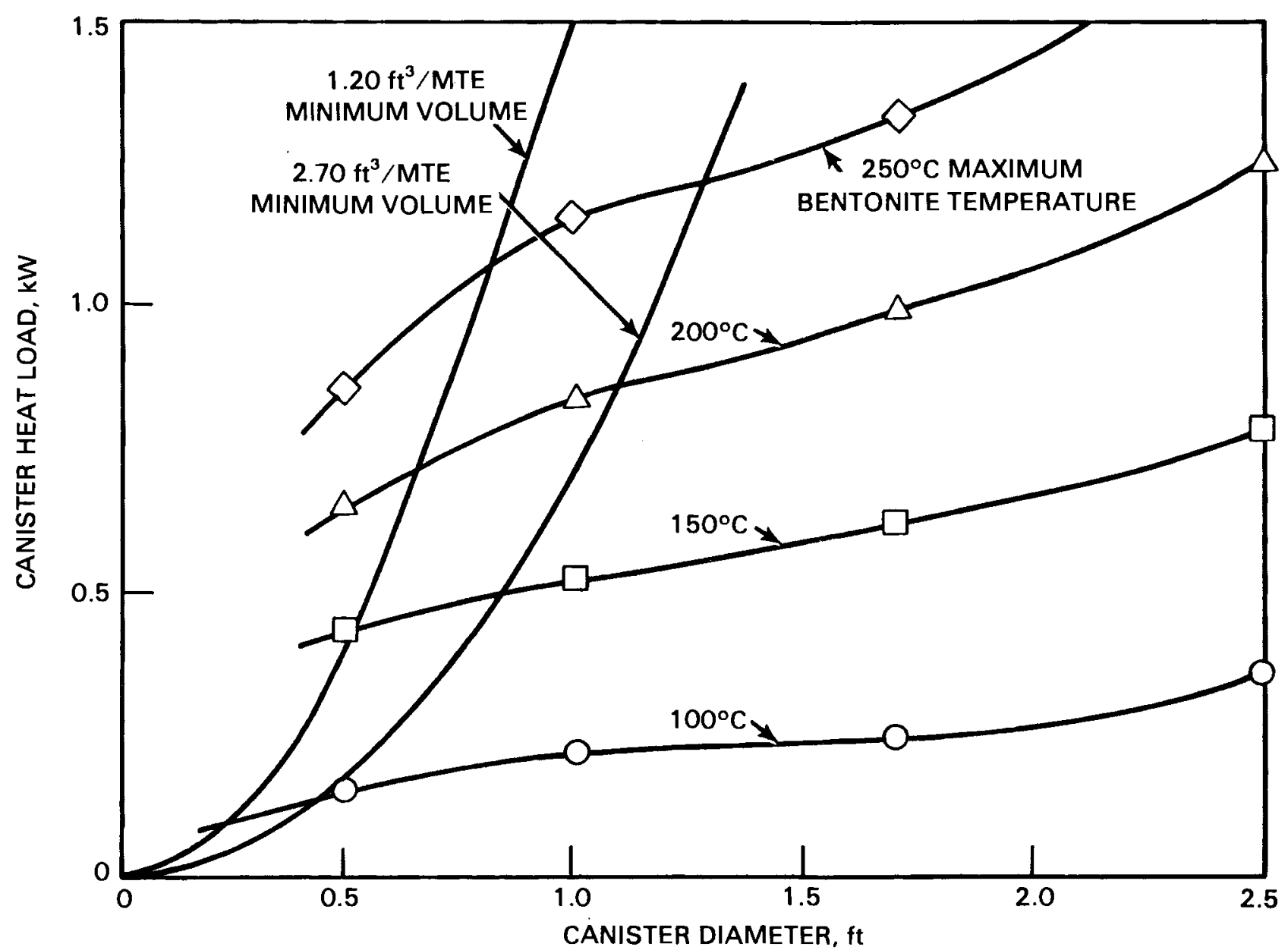

FIGURE 5.15. Optimum Canister Heat Loading Determination for FHLW Recycle Case 


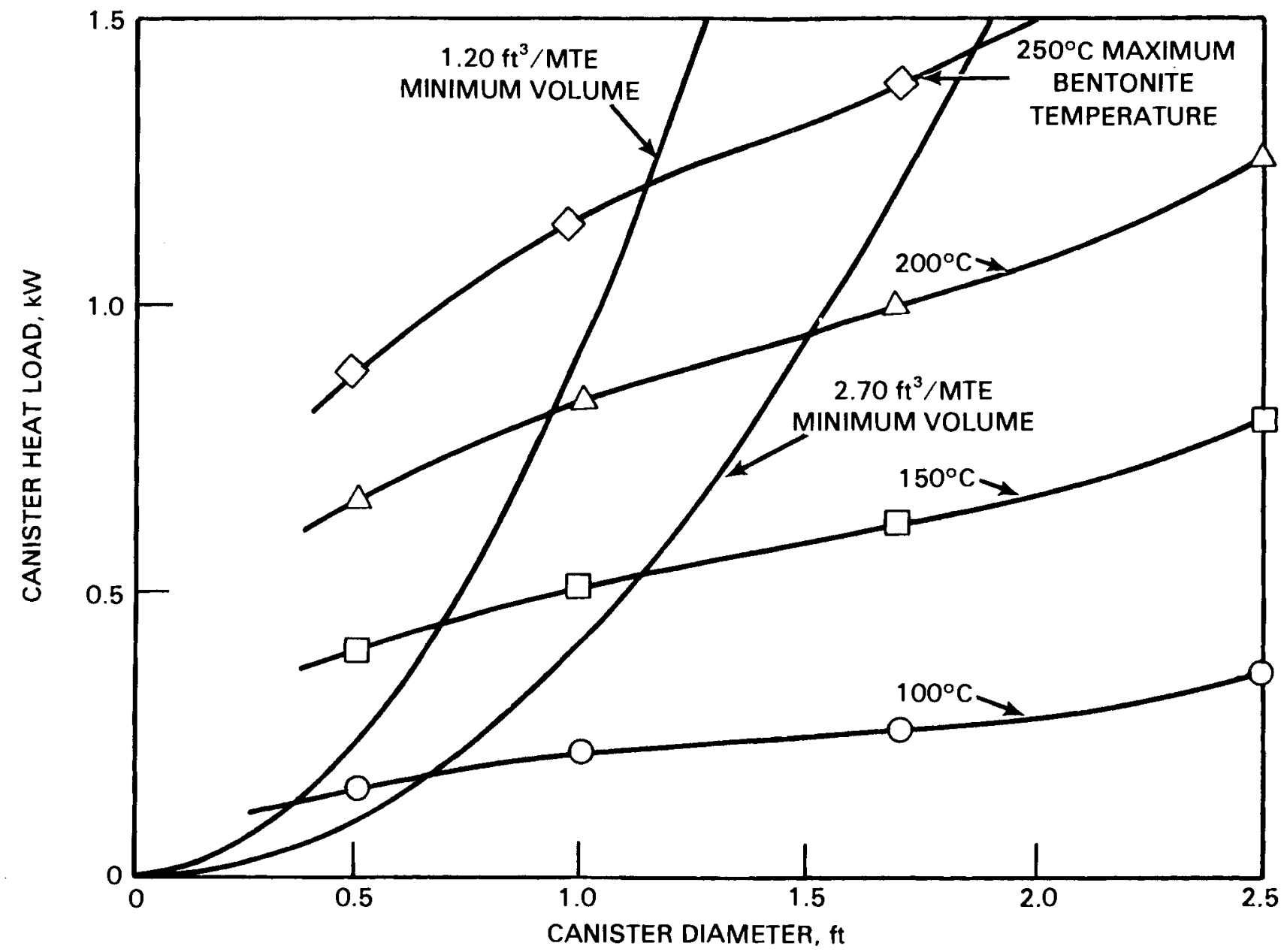

FIGURE 5.16. Optimum Canister Heat Loading Determination for FHLW No-Recycle Case 


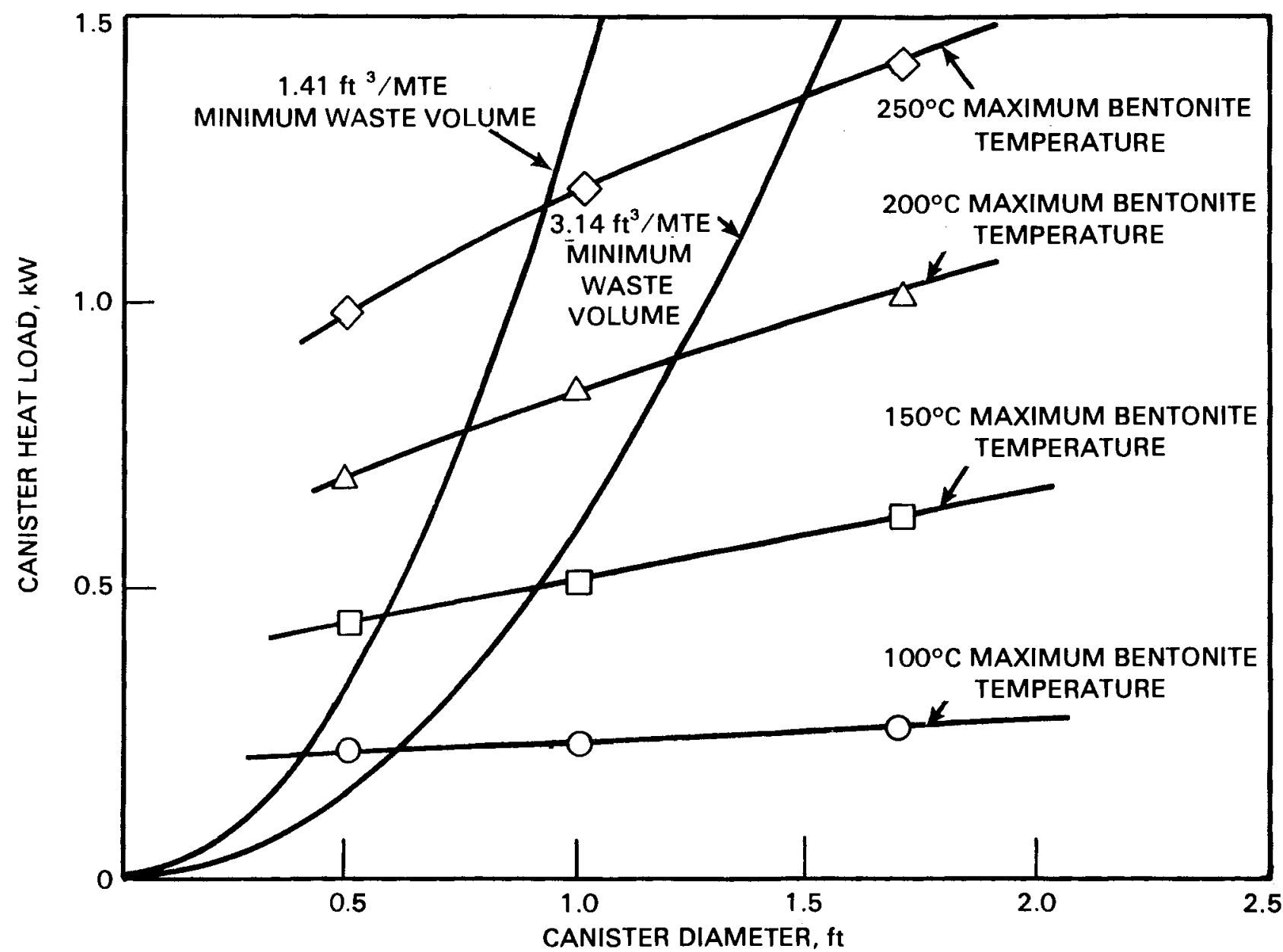

FIGURE 5.17. Optimum Canister Heat Loading Determination for Aged-HLW (0.3kW/MTE) 


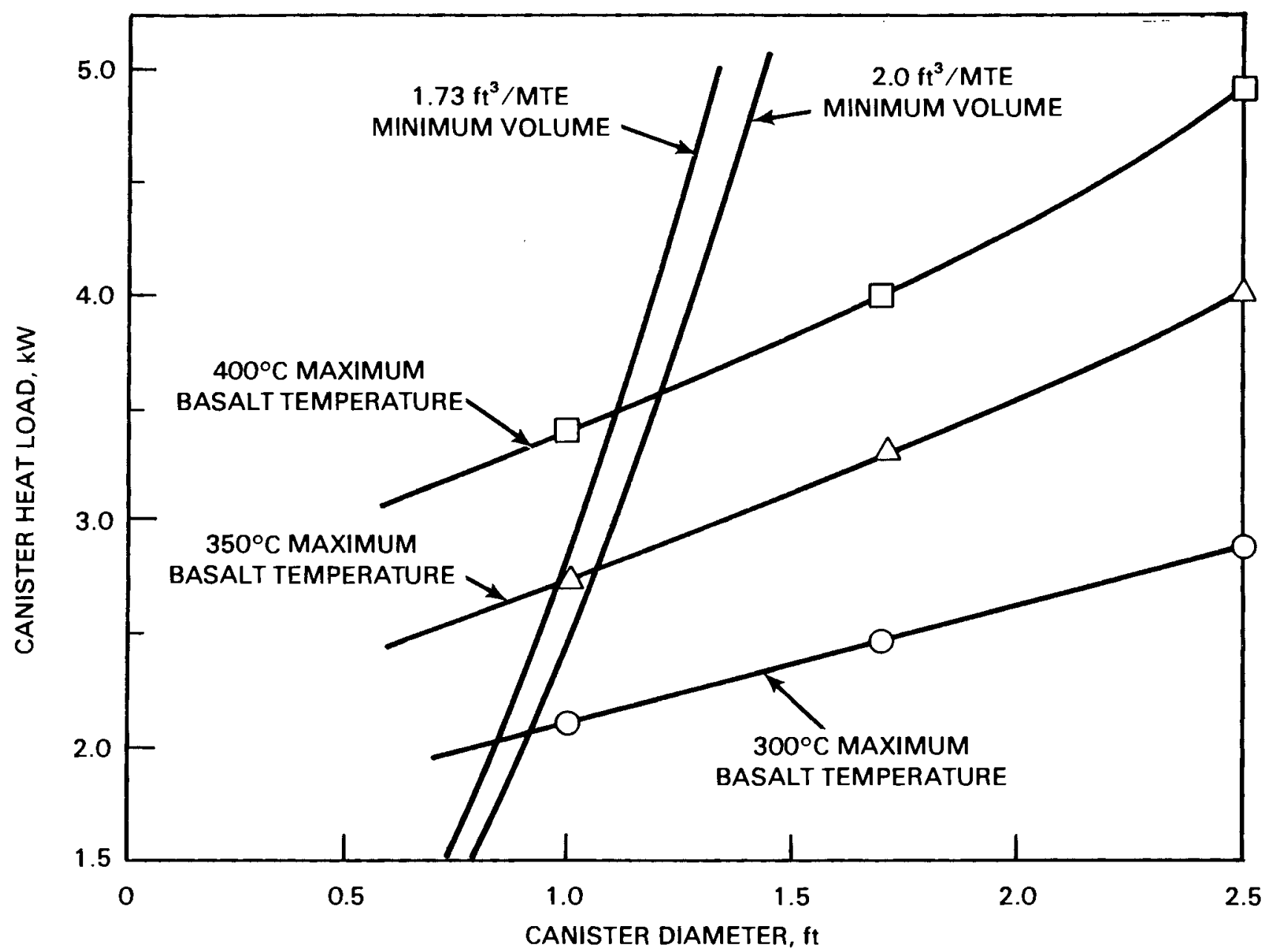

FIGURE 5.18. Optimum Canister Heat Loading Determination for Cs/Sr Waste 
TABLE 5.6. Comparison of Total System Costs for HLW, FHLW, and Aged-HLW; Disposal with Bentonite Backfill (billions of 1982 dollars)

Maximum Bentonite

Temperature, ${ }^{\circ} \mathrm{C}$

100

150

200

250

Approximate Maximum

Centerline Temp., ${ }^{\circ} \mathrm{C}$

$125 \quad 190$

255

320

HLW

$\begin{array}{lllll}1.41 \mathrm{ft}^{3} / \text { MTE } & 18.8 & 10.0 & 7.5 & 6.1 \\ 1600 \text {-acre Repos. } & 20.5 & 11.8 & 7.9 & 6.2 \\ 3.14 \mathrm{ft}^{3} / \text { MTE } & 18.8 & 10.0 & 7.6 & 7.1\end{array}$

FHLW Recycle Case ${ }^{(a)}$

$\begin{array}{lrrrr}1.20 \mathrm{ft}^{3} / \text { MTE } & 9.9 & 7.2 & 6.6 & 6.3 \\ 1600 \text {-acre Repos. } & 10.1 & 7.6 & 6.8 & 6.3 \\ 2.70 \mathrm{ft}^{3} / \text { MTE } & 9.9 & 7.9 & 7.0 & 6.7\end{array}$

FHLW No-Recycle Case ${ }^{(a)}$

$\begin{array}{lllll}1.20 \mathrm{ft}^{3} / \text { MTE } & 8.2 & 6.6 & 6.3 & 6.0 \\ 1600 \text {-acre Repos. } & 8.2 & 6.7 & 6.3 & 5.9 \\ 2.70 \mathrm{ft}^{3} / \text { MTE } & 8.4 & 7.0 & 6.5 & 6.2\end{array}$

Aged-HLW

$\begin{array}{lrrrr}1.41 \mathrm{ft}^{3} / \text { MTE } & 9.6 & 6.3 & 5.4 & 4.9 \\ 600 \text {-acre Repos. } & 10.3 & 6.3 & 5.1 & 4.1 \\ 3.14 \mathrm{ft}^{3} / \text { MTE } & 10.6 & 7.3 & 6.2 & 5.6\end{array}$

(a) The HLW cases include the incremental costs for disposal of the $\mathrm{Cs} / \mathrm{Sr}$ waste in the same repository.

The FHLW no-recycle case shows lower costs than the recycle case, with the greatest difference at the lowest maximum temperatures.

The costs for the aged-HLW disposal alternative show a substantial advantage relative to HLW disposal over the entire temperature range, indicating that, from a cost standpoint, this may be the most attractive alternative. However, at the low end of the maximum temperature range, 

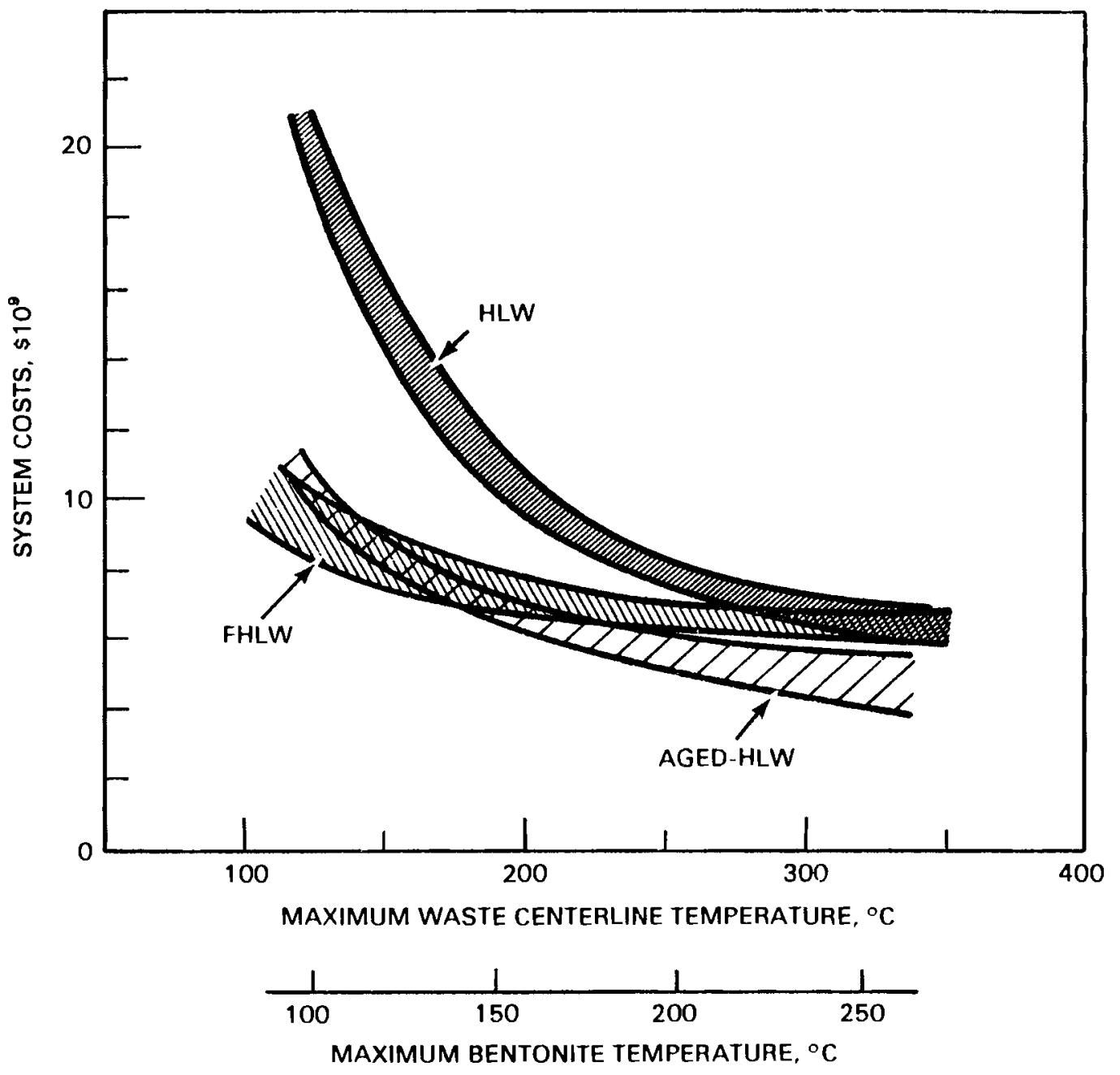

FIGURE 5.19. Total 50,000 MTE System Cost Comparison for $H L W$, Aged-HLW, and Fractionated HLW Disposal with Bentonite Backfill

the costs for aged-HLW disposal are equal or greater than the costs for the FHLW disposal. If a cost-of-money discount rate is used, even if, say, only $2 \%$, the repository costs for the aged-HLW case may be reduced by two-thirds or more and this alternative is significantly enhanced.

Another important consideration in comparing these alternatives is the total repository area requirement. These area requirements are compared in Table 5.7. These repository areas include approximately 530 acres for a central pillar exclusion area and access corridor areas. The FHLW cases include the area requirements for the $\mathrm{Cs} / \mathrm{Sr}$ waste assumed 
TABLE 5.7. Comparison of Total Repository Area Requirements for HLW, FHLW, and Aged-HLW with Bentonite Backfill, Acres

Maximum Bentonite

Temperature, ${ }^{\circ} \mathrm{C}$

$\underline{100} \quad \underline{150} \quad \underline{200} \quad \underline{250}$

HLW

$\begin{array}{lllll}1.41 \mathrm{ft}^{3} / \text { MTE } & 5010 & 3500 & 2430 & 1960 \\ 3.14 \mathrm{ft}^{3} / \text { MTE } & 5010 & 3500 & 2420 & 1910\end{array}$

FHLW Recycle Case ${ }^{(a)}$

$\begin{array}{lllll}1.20 \mathrm{ft}^{3} / \text { MTE } & 2490 & 2160 & 1830 & 1600 \\ 2.70 \mathrm{ft}^{3} / \text { MTE } & 2490 & 2140 & 1760 & 1600\end{array}$

FHLW No-Recycle Case ${ }^{(a)}$

$\begin{array}{lllll}1.20 \mathrm{ft}^{3} / \text { MTE } & 1980 & 1800 & 1640 & 1510 \\ 2.70 \mathrm{ft}^{3} / \text { MTE } & 2300 & 1770 & 1570 & 1470\end{array}$

Aged-HLW

$\begin{array}{lllll}1.41 \mathrm{ft}^{3} / \text { MTE } & 2890 & 1610 & 1200 & 910 \\ 3.14 \mathrm{ft}^{3} / \text { MTE } & 3050 & 1670 & 1200 & 970\end{array}$

(a) The FHLW cases include the incremental costs for disposal of the $\mathrm{Cs} / \mathrm{Sr}$ waste in the same repository.

to be in a separate section of this same repository. The FHLW cases show lower repository area requirements over the entire temperature range, with an approximate two-fold difference at the $100^{\circ} \mathrm{C}$ maximum bentonite temperature. The FHLW no-recycle case shows an area advantage over the recycle case. The aged-HLW case has a substantially lower area requirement compared to both the FHLW and the $H L W$ cases at the $250^{\circ} \mathrm{C}$ maximum bentonite temperature, but has a higher area requirement than the $\mathrm{FHLW}$ cases at the $100^{\circ} \mathrm{C}$ bentonite temperature.

Both the repository area requirements and costs for FHLW and aged-HLW compared to the reference HLW are substantially lower at the low bentonite temperatures, indicating that these low temperatures might be feasible with 
either the fractionation or aged-HLW concept; whereas they may not be with the reference disposal concept because of the large area requirement and high costs.

netails of the emplacement features and system costs for HLW at $1.41 \mathrm{ft}^{3} /$ MTE for the four maximum bentonite temperatures are shown in Table 5.8. This table shows canister size, canister loading, canister pitch, total canisters required, areal heat loading, and the repository area requirement as well as a breakdown of the total costs. Total costs increase from approximately $\$ 6$ billion at the $250^{\circ} \mathrm{C}$ maximum bentonite temperature to almost $\$ 19$ billion at the $100^{\circ} \mathrm{C}$ maximum bentonite temperature. Repository acreage increases from approximately 2,000 to approximately 5,000 acres. Table 5.8 also shows the capacity and cost for a 1600-acre repository as well as the total system cost if multiple 1600-acre repositories were used for disposal in a 50,000 MTE system. In the case of the $100^{\circ} \mathrm{C}$ maximum bentonite temperature, it is questionable whether either the single large 5,000-acre repository or four-plus smaller repositories would be feasible.

Emplacement features and costs for HLW at $3.14 \mathrm{ft}^{3} /$ MTE are shown in Table 5.9. These costs are the same as in the previous table for the $100^{\circ} \mathrm{C}$ and $150^{\circ} \mathrm{C}$ temperatures because in both cases they are limited by the $0.5-\mathrm{ft}$ diameter criteria. Somewhat larger canisters are required for the $200^{\circ} \mathrm{C}$ and $250^{\circ} \mathrm{C}$ cases, which results in increased costs, particularly for the $250^{\circ} \mathrm{C}$ case.

Emplacement features and system costs for the FHLW recycle case at $1.2 \mathrm{ft}^{3} /$ MTE are shown in Table 5.10. The upper portion of the table shows the requirements and costs for the FHLW component of the waste, and the lower portion shows the incremental costs for adding the $\mathrm{Cs} / \mathrm{Sr}$ waste to the same repository. The combined area and costs are then shown in Table 5.11, with additional information showing the cost if the repositories were restricted to a 1600-acre size. The 1600-acre limitation has small impact on total cost requirements. Emplacement features for the fractionation recycle case with FHLW at $2.7 \mathrm{ft}^{3} /$ MTE are shown in Table 5.12. Repository area and total cost requirements are similar to the previous case. The emplacement features and 
TABLE 5.8. Repository Emplacement Features and System Costs for HLW at $1.41 \mathrm{ft}^{3}$ /MTE

\begin{tabular}{|c|c|c|c|c|}
\hline & \multicolumn{4}{|c|}{$\begin{array}{c}\text { Maximum Bentonite } \\
\text { Temperature, }{ }^{\circ} \mathrm{C}\end{array}$} \\
\hline & 100 & 150 & 200 & 250 \\
\hline Canister Diameter, ft & 0.50 & 0.50 & 0.50 & 0.50 \\
\hline \multicolumn{5}{|l|}{ Canister Loading } \\
\hline $\mathrm{kW}$ & 0.16 & 0.42 & 0.69 & 0.98 \\
\hline MTE & 0.15 & 0.39 & 0.63 & 0.91 \\
\hline Canister Pitch, m & 2.3 & 4.0 & 4.2 & 4.5 \\
\hline $\begin{array}{l}\text { Canisters Per } 50,000 \text { MTE, } 10^{3} \\
\text { Areal Heat Load, kW/acre } \\
\text { Repository Area, acres } \\
50,000 \text { MTE System } \\
\text { Costs, } \$ 10^{9}\end{array}$ & $\begin{array}{r}338 \\
12 \\
5010\end{array}$ & $\begin{array}{r}129 \\
18.2 \\
3500\end{array}$ & $\begin{array}{l}78.2 \\
28.5 \\
2430\end{array}$ & $\begin{array}{l}55.1 \\
37.8 \\
1960\end{array}$ \\
\hline Fractionation & - & - & - & - \\
\hline Vitrification & 4.73 & 2.20 & 1.53 & 1.19 \\
\hline Transportation & 2.02 & 0.80 & 0.50 & 0.36 \\
\hline Long-Term Storage & - & - & - & - \\
\hline Repository & 12.0 & 6.97 & 5.48 & 4.51 \\
\hline $\begin{aligned} \text { Total System, } & w / T i-c l a d \text { OP } \\
& w / 0 \text { Ti-clad OP }\end{aligned}$ & $\begin{array}{l}18.75 \\
17.5\end{array}$ & $\begin{array}{l}9.97 \\
9.5\end{array}$ & $\begin{array}{l}7.51 \\
7.2\end{array}$ & $\begin{array}{l}6.06 \\
5.9\end{array}$ \\
\hline \multicolumn{5}{|l|}{ 1600-acre Repository } \\
\hline Capacity, $10^{3} / \mathrm{MTE}$ & 11.6 & 17.2 & 26.8 & 35.5 \\
\hline Costs, $\$ 10^{9}$ & 3.2 & 3.0 & 3.1 & 3.3 \\
\hline $\begin{array}{l}50,000 \mathrm{MTE}_{9} \text { System } \\
\text { Costs, } \$ 10\end{array}$ & 20.5 & 11.8 & 7.9 & 6.2 \\
\hline
\end{tabular}

system costs for the no-recycle fraction are shown in Tables 5.13, 5.14, and 5.15 comparable to the three FHLW recycle case tables. Both the area requirements and costs are reduced relative to the recycle case. The largest differences are at the $100^{\circ} \mathrm{C}$ maximum bentonite temperature. 
TABLE 5.9. Repository Emplacement Features and System Costs for HLW at $3.14 \mathrm{ft}^{3} / \mathrm{MTE}$

\begin{tabular}{|c|c|c|c|c|}
\hline & \multicolumn{4}{|c|}{$\begin{array}{c}\text { Maximum Bentonite } \\
\text { Temperature, }{ }^{\circ} \mathrm{C}\end{array}$} \\
\hline & 100 & 150 & 200 & 250 \\
\hline Canister Diameter, ft & 0.50 & 0.50 & 0.55 & 0.64 \\
\hline \multicolumn{5}{|l|}{ Canister Loading } \\
\hline $\mathrm{kW}$ & 0.16 & 0.42 & 0.71 & 1.04 \\
\hline MTE & 0.15 & 0.39 & 0.66 & 0.96 \\
\hline Canister Pitch, m & 2.3 & 4.0 & 4.3 & 4.6 \\
\hline $\begin{array}{l}\text { Canisters Per } \\
50,000 \text { MTE, } 10^{3}\end{array}$ & 338 & 129 & 75.8 & 52.1 \\
\hline Areal Heat Load, kW/acre & 12 & 18.2 & 28.6 & 39.2 \\
\hline Repository Area, acres & 5010 & 3500 & 2420 & 1910 \\
\hline \multirow{2}{*}{$\begin{array}{l}\text { 50,000 MTE System } \\
\text { Costs, } \$ 109, \text { w/Ti-clad OP } \\
\text { w/o Ti-clad OP }\end{array}$} & 18.75 & 9.97 & 7.6 & 7.1 \\
\hline & 17.5 & 9.5 & 7.3 & 6.9 \\
\hline
\end{tabular}


TABLE 5.10. Repository Emplacement Features and System Costs for FHLW (recycle case) at $1.20 \mathrm{ft}^{3} / \mathrm{MTE}$

\begin{tabular}{|c|c|c|c|c|}
\hline & & $\begin{array}{l}\text { aximum } \\
\text { Temper }\end{array}$ & $\begin{array}{l}\text { entonit } \\
\text { ure, of }\end{array}$ & \\
\hline & 100 & 150 & 200 & 250 \\
\hline Canister Diameter, ft & 0.50 & 0.50 & 0.70 & 0.85 \\
\hline Canister Loading & & & & \\
\hline 0.16 & 0.44 & 0.75 & 1.10 & \\
\hline 0.53 & 1.45 & 2.48 & 3.63 & \\
\hline Canister Pitch, m & 2.3 & 4.6 & 5.0 & 4.5 \\
\hline $\begin{array}{l}\text { Canisters Per } \\
50,000 \text { MTE, } 10^{3}\end{array}$ & 94.7 & 34.4 & 20.2 & 13.8 \\
\hline Areal Heat Load, kW/acre & 12.1 & 16.6 & 26.0 & 42.4 \\
\hline Repository Area, acres (a) & 1790 & 1460 & 1130 & 900 \\
\hline $\begin{array}{l}50,000 \text { MTE System } \\
\text { Costs, } \$ 10^{9}\end{array}$ & & & & \\
\hline Fractionation & 0.88 & 0.88 & 0.88 & 0.88 \\
\hline Vitrification & 1.26 & 0.59 & 0.48 & 0.42 \\
\hline Transportation & 0.57 & 0.21 & 0.22 & 0.21 \\
\hline Long-Term Storage & - & - & - & \\
\hline Repository & 5.34 & 3.76 & 3.38 & 3.12 \\
\hline Subtotal FHLW System & 8.05 & 5.44 & 4.96 & 4.63 \\
\hline $\begin{array}{l}\text { Incremental Costs for Cs/Sr } \\
\text { Waste in Same Repository, } \$ 10^{9}\end{array}$ & & & & \\
\hline Vitrification & 0.53 & 0.53 & 0.53 & 0.53 \\
\hline Transportation & 0.29 & 0.29 & 0.29 & 0.29 \\
\hline Repository & 1.01 & 0.94 & 0.85 & 0.83 \\
\hline Subtotal & 1.83 & 1.76 & 1.67 & 1.65 \\
\hline TOTAL SYSTEM & 9.88 & 7.20 & 6.63 & 6.28 \\
\hline
\end{tabular}

(a) An additional 700 acres of emplacement area is required for the $\mathrm{Cs} / \mathrm{Sr}$ waste if placed in the same repository. For details of optimum $\mathrm{Cs} / \mathrm{Sr}$ waste characteristics, see Table 5.18, Column 1. 
TABLE 5.11. Combined Area Requirements and System Costs for FHLW (recycle case) at $1.20 \mathrm{ft}^{3} /$ MTE with $\mathrm{Cs} / \mathrm{Sr}$ Waste in the Same Repository

\begin{tabular}{|c|c|c|c|c|}
\hline & & $\begin{array}{l}\text { aximum } \\
\text { Tempera }\end{array}$ & $\begin{array}{l}\text { ntonite } \\
\text { re, }{ }^{\circ} \mathrm{C}\end{array}$ & \\
\hline & 100 & 150 & 200 & 250 \\
\hline Repository Area, acres & 2490 & 2160 & 1830 & 1600 \\
\hline $\begin{array}{l}50,000 \text { MTE System } \\
\text { Costs, } \$ 10^{9}\end{array}$ & & & & \\
\hline Fractionation & 0.88 & 0.88 & 0.88 & 0.88 \\
\hline Vitrification & 1.79 & 1.12 & 1.01 & 0.95 \\
\hline Transportation & 0.86 & 0.50 & 0.51 & 0.50 \\
\hline Long-Term Storage & - & - & - & - \\
\hline Repository & 6.35 & 4.70 & 4.23 & 3.95 \\
\hline Total System & 9.88 & 7.20 & 6.63 & 6.28 \\
\hline 1600-Acre Repository & & & & \\
\hline Capacity, $10^{3}$ MTE & 26.8 & 31.6 & 40.0 & 50.0 \\
\hline Costs, $\$ 10^{9}$ & 3.5 & 3.2 & 3.5 & 4.0 \\
\hline $\begin{array}{l}\text { 50,000 MTE } \\
\text { System Costs, } \$ 10^{9}\end{array}$ & 10.1 & 7.6 & 6.8 & 6.3 \\
\hline
\end{tabular}


TABLE 5.12. Repository Emplacement Features and System Costs for FHLW (recycle case) at $2.70 \mathrm{ft}^{3} / \mathrm{MTE}$

\begin{tabular}{|c|c|c|c|c|}
\hline & & $\begin{array}{l}\text { aximum } \\
\text { Temper }\end{array}$ & $\begin{array}{l}\text { tonite } \\
\text { e, }{ }^{\circ} \mathrm{C}\end{array}$ & \\
\hline & 100 & 150 & 200 & 250 \\
\hline Canister Diameter, ft & 0.50 & 0.83 & 1.09 & 1.28 \\
\hline Canister Loading & & & & \\
\hline $\mathrm{kW}$ & 0.16 & 0.49 & 0.86 & 1.22 \\
\hline MTE & 0.53 & 1.62 & 2.84 & 4.03 \\
\hline Canister Pitch, m & 2.3 & 5.1 & 5.2 & 5.2 \\
\hline $\begin{array}{l}\text { Canisters Per } \\
50,000 \text { MTE, } 10^{3}\end{array}$ & 94.7 & 30.9 & 17.6 & 12.4 \\
\hline Areal Heat Load, kW/acre & 12.1 & 16.7 & 28.7 & 40.7 \\
\hline Repository Area, acres(a) & 1790 & 1440 & 1060 & 900 \\
\hline $\begin{array}{l}50,000 \text { MTE FHLW System } \\
\text { Costs, } \$ 10^{9}\end{array}$ & 8.05 & 6.1 & 5.3 & 5.0 \\
\hline $\begin{array}{l}\text { Incremental Costs for } \\
\text { Cs/Sr Waste, } \$ 10^{9}\end{array}$ & 1.83 & 1.8 & 1.7 & 1.7 \\
\hline TOTAL SYSTEM COSTS, $\$ 10^{9}$ & 9.88 & 7.9 & 7.0 & 6.7 \\
\hline
\end{tabular}

(a) An additional 700 acres of emplacement area is required for the $\mathrm{Cs} / \mathrm{Sr}$ waste if placed in the same repository. For details of optimum Cs/Sr waste characteristics, see Table 5.18, Column 1 . 
TABLE 5.13. Repository Emplacement Features and System Costs for FHLW (no-recycle case) at $1.20 \mathrm{ft}^{3} / \mathrm{MTE}$

\begin{tabular}{|c|c|c|c|c|}
\hline & & $\begin{array}{l}\text { aximum } \\
\text { Tempera }\end{array}$ & $\begin{array}{l}\text { ntonite } \\
\text { re, }{ }^{\circ} \mathrm{C}\end{array}$ & \\
\hline & 100 & 150 & 200 & 250 \\
\hline Canister Diameter, ft & 0.50 & 0.70 & 0.95 & 1.15 \\
\hline Canister Loading & & & & \\
\hline$k W$ & 0.16 & 0.46 & 0.82 & 1.22 \\
\hline MTE & 0.89 & 2.56 & 4.56 & 6.78 \\
\hline Canister Pitch, m & 2.3 & 5.0 & 6.5 & 6.5 \\
\hline $\begin{array}{l}\text { Canisters Per } \\
50,000 \text { MTE, } 10^{3}\end{array}$ & 56.3 & 19.6 & 11.0 & 7.38 \\
\hline Areal Heat Load, kW/acre & 12.1 & 16.0 & 21.9 & 32.5 \\
\hline Repository Area, acres(a) & 1280 & 1100 & 940 & 810 \\
\hline $\begin{array}{l}50,000 \text { MTE System } \\
\text { Costs, } \$ 10^{9}\end{array}$ & & & & \\
\hline Fractionation & 0.88 & 0.88 & 0.88 & 0.88 \\
\hline Vitrification & 0.86 & 0.47 & 0.38 & 0.34 \\
\hline Transportation & 0.34 & 0.22 & 0.19 & 0.15 \\
\hline Long-Term Storage & - & - & - & - \\
\hline Repository & 4.04 & 3.34 & 3.11 & 2.96 \\
\hline Subtotal FHLW System & 6.12 & 4.91 & 4.56 & 4.33 \\
\hline $\begin{array}{l}\text { Incremental Costs for } \\
\text { Cs/Sr Waste, } \$ 10^{9}\end{array}$ & & & & \\
\hline Vitrification & 0.53 & 0.53 & 0.53 & 0.53 \\
\hline Transportation & 0.29 & 0.29 & 0.29 & 0.29 \\
\hline Repository & 1.25 & 0.86 & 0.88 & 0.86 \\
\hline Subtotal & 2.07 & 1.68 & 1.70 & 1.68 \\
\hline TOTAL SYSTEM & 8.19 & 6.59 & 6.26 & 6.01 \\
\hline
\end{tabular}

(a) An additional 700 acres of emplacement area is required for the $\mathrm{Cs} / \mathrm{Sr}$ waste if placed in the same repository. For details of optimum $\mathrm{Cs} / \mathrm{Sr}$ waste characteristics, see Table 5.18, Column 1. 
TABLE 5.14. Combined Area Requirements and System Costs for FHLW (no-recycle case) at $1.20 \mathrm{ft}^{3} /$ MTE with $\mathrm{Cs} / \mathrm{Sr}$ Waste in the Same Repository

Repository Area, acres

Maximum Bentonite

50,000 MTE System Costs, $\$ 10^{9}$

Fractionation

Vitrification

Transportation

Long-Term Storage

Repository

Total system

1600-Acre Repository

Capacity, $10^{3}$ MTE

Costs, $\$ 10^{9}$

$\begin{array}{llll}0.88 & 0.88 & 0.88 & 0.88\end{array}$

$\begin{array}{llll}1.39 & 1.00 & 0.91 & 0.87\end{array}$

$\begin{array}{llll}0.63 & 0.51 & 0.48 & 0.44\end{array}$

50,000 MTE System Costs, $\$ 10^{9}$

\begin{tabular}{|c|c|c|c|}
\hline \multicolumn{4}{|c|}{$\begin{array}{c}\text { Maximum Bentonite } \\
\text { Temperature, }{ }^{\circ} \mathrm{C}\end{array}$} \\
\hline 100 & 150 & 200 & 250 \\
\hline 1980 & 1800 & 1640 & 1510 \\
\hline 0.88 & 0.88 & 0.88 & 0.88 \\
\hline 1.39 & 1.00 & 0.91 & 0.87 \\
\hline 0.63 & 0.51 & 0.48 & 0.44 \\
\hline- & - & - & - \\
\hline 5.29 & 4.20 & 3.99 & 3.82 \\
\hline 8.19 & 6.59 & 6.26 & 6.01 \\
\hline 36.2 & 40.5 & 45.7 & 52.6 \\
\hline 3.8 & 3.5 & 3.7 & 3.9 \\
\hline 8.2 & 6.7 & 6.3 & 5.9 \\
\hline
\end{tabular}


TABLE 5.15. Repository Emplacement Features and System Costs for FHLW (no-recycle case) at $2.70 \mathrm{ft}^{3} / \mathrm{MTE}$

\begin{tabular}{|c|c|c|c|c|}
\hline & & $\begin{array}{l}\text { aximum } \\
\text { Tempera }\end{array}$ & $\begin{array}{l}\text { itonite } \\
\text { ee, }{ }^{\circ} \mathrm{C}\end{array}$ & \\
\hline & 100 & 150 & 200 & 250 \\
\hline Canister Diameter, ft & 0.66 & 1.12 & 1.50 & 1.86 \\
\hline Canister Loading & & & & \\
\hline$k W$ & 0.18 & 0.53 & 0.95 & 1.45 \\
\hline MTE & 1.00 & 2.94 & 5.28 & 8.06 \\
\hline Canister Pitch, m & 3.7 & 5.5 & 6.3 & 6.8 \\
\hline $\begin{array}{l}\text { Canisters Per } \\
50,000 \text { MTE, } 10^{3}\end{array}$ & 50.0 & 17.0 & 9.47 & 6.21 \\
\hline Areal Heat Load, kW/acre & 8.4 & 16.7 & 26.2 & 37.0 \\
\hline Repository Area, acres (a) & 1600 & 1070 & 870 & 770 \\
\hline $\begin{array}{l}50,000 \text { MTE HIW System } \\
\text { Costs, } \$ 10 \mathrm{~g}^{\mathrm{W}} \\
\text { Incremental Costs for }\end{array}$ & 6.3 & 5.3 & 4.8 & 4.5 \\
\hline $\mathrm{Cs} / \mathrm{Sr}$ Waste, $\$ 10^{9}$ & 2.1 & 1.7 & 1.7 & 1.7 \\
\hline TOTAL SYSTEM COSTS, $\$ 10^{9}$ & 8.4 & 7.0 & 6.5 & 6.2 \\
\hline
\end{tabular}

(a) An additional 700 acres of emplacement area is required for the $\mathrm{Cs} / \mathrm{Sr}$ waste if placed in the same repository. For details of optimum Cs/Sr waste characteristics, see Table 5.18, Column 1.

The emplacement features and system costs for $H L W$ aged to the same heat output as the FHLW recycle case are shown in Tables 5.16 and 5.17 for $1.41 \mathrm{ft}^{3} /$ MTE and $3.14 \mathrm{ft}^{3} /$ MTE, respectively. Except at the $100^{\circ} \mathrm{C}$ bentonite temperature, the aged-HLW system shows an advantage both in reduced repository area requirements and total system costs relative to both the fractionation cases and the reference HLW cases.

The emplacement features and system costs for the Cs/Sr waste are shown in Tables 5.18 and 5.19 for waste volumes of 2 and $1.73 \mathrm{ft}^{3} / \mathrm{MTE}$, respectively. The differences between the results with these two waste volume cases are not 
TABLE 5.16. Repository Emplacement Features and System Costs for Aged-HLW at $1.41 \mathrm{ft}^{3} / \mathrm{MTE}$

\begin{tabular}{|c|c|c|c|c|}
\hline & & $\begin{array}{l}\text { aximum } \\
\text { Tempera }\end{array}$ & $\begin{array}{l}\text { itonite } \\
\text { re, }{ }^{\circ} \mathrm{C}\end{array}$ & \\
\hline & 100 & 150 & 200 & 250 \\
\hline Canister Diameter, ft & 0.5 & 0.6 & 0.76 & 0.92 \\
\hline Canister Loading & & & & \\
\hline$k W$, final & 0.22 & 0.48 & 0.77 & 1.13 \\
\hline initial & 0.79 & 1.72 & 2.77 & 4.07 \\
\hline MTE & 0.733 & 1.60 & 2.57 & 3.77 \\
\hline Canister Pitch, m & 6.0 & 6.0 & 6.0 & 5.0 \\
\hline $\begin{array}{l}\text { Canisters Per } \\
50,000 \text { MTE, } 10^{3}\end{array}$ & 68.2 & 31.3 & 19.5 & 13.3 \\
\hline Areal Heat Load, kW/acre & 6.4 & 13.9 & 22.3 & 39.2 \\
\hline Repository Area, acres & 2890 & 1610 & 1200 & 910 \\
\hline $\begin{array}{l}50,000 \text { MTE System } \\
\text { Costs, } \$ 10^{9}\end{array}$ & & & & \\
\hline Fractionation & - & - & - & - \\
\hline Vitrification & 1.36 & 0.88 & 0.71 & 0.63 \\
\hline Transportation & 0.41 & 0.28 & 0.24 & 0.23 \\
\hline Long-Term Storage & 2.05 & 1.16 & 0.98 & 0.82 \\
\hline Repository & 5.75 & 3.95 & 3.48 & 3.22 \\
\hline TOTAL SYSTEM & 9.57 & 6.27 & 5.38 & 4.90 \\
\hline 1600-Acre Repository & & & & \\
\hline Capacity, $10^{3}$ MTE & 21.5 & 47.0 & 75.2 & 109 \\
\hline Costs, $\$ 10^{9}$ & 2.8 & 3.7 & 4.8 & 5.3 \\
\hline $\begin{array}{l}\text { 50,000 MTE System } \\
\text { Costs, } \$ 10^{9}\end{array}$ & 10.3 & 6.3 & 5.1 & 4.1 \\
\hline
\end{tabular}


TABLE 5.17. Repository Emplacement Features and System Costs for Aged-HLW at $3.14 \mathrm{ft}^{3} / \mathrm{MTE}$

\begin{tabular}{|c|c|c|c|c|}
\hline & & $\begin{array}{l}\text { Maximum } \\
\text { Temper }\end{array}$ & $\begin{array}{l}\text { tonite } \\
\text { re, }{ }^{\circ} \mathrm{C}\end{array}$ & \\
\hline & 100 & 150 & 200 & 250 \\
\hline Canister Diameter, ft & 0.63 & 0.94 & 1.22 & 1.50 \\
\hline Canister Loading & & & & \\
\hline kW, final & 0.24 & 0.53 & 0.90 & 1.36 \\
\hline initial & 0.86 & 1.91 & 3.24 & 4.90 \\
\hline 0.80 & 1.77 & 1.77 & 4.53 & \\
\hline Canister Pitch, m & 7 & 7 & 7 & 7 \\
\hline $\begin{array}{l}\text { Canisters Per } \\
50,000 \text { MTE, } 10^{3}\end{array}$ & 62.5 & 228.2 & 16.7 & 11.0 \\
\hline Areal Heat Load, kW/acre & 6.0 & 113.1 & 22.3 & 33.7 \\
\hline Repository area, acres & 3050 & 1670 & 1200 & 970 \\
\hline $\begin{array}{l}50,000 \text { MTE System } \\
\text { Costs, } \$ 10^{9}\end{array}$ & 10.6 & 7.3 & 6.2 & 5.6 \\
\hline
\end{tabular}


TABLE 5.18. Repository Emplacement Features and System Costs for $\mathrm{Cs} / \mathrm{Sr}$ Waste at $2.0 \mathrm{ft}^{3} / \mathrm{MTE}$

\begin{tabular}{|c|c|c|c|}
\hline & \multicolumn{3}{|c|}{$\begin{array}{l}\text { Maximum Basalt } \\
\text { Temperature, }{ }^{\circ} \mathrm{C}\end{array}$} \\
\hline & 300 & 350 & 400 \\
\hline Canister Diameter, ft & 0.95 & 1.10 & 1.23 \\
\hline \multicolumn{4}{|l|}{ Canister Loading } \\
\hline $\mathrm{kW}$ & 2.25 & 2.85 & 3.65 \\
\hline MTE & 2.90 & 3.67 & 4.70 \\
\hline Canister Pitch, m & 7.0 & 6.2 & 6.5 \\
\hline $\begin{array}{l}\text { Canisters Per } \\
50,000 \text { MTE, } 10^{3}\end{array}$ & 17.2 & 13.6 & 10.6 \\
\hline Areal Heat Load, kW/acre & 55.7 & 79.7 & 97.4 \\
\hline \multicolumn{4}{|l|}{ Repository Area, acres } \\
\hline Single Purpose Repository & 1220 & 1020 & 930 \\
\hline Shared Repository & 700 & 500 & 400 \\
\hline \multicolumn{4}{|l|}{$\begin{array}{l}\text { 50,000 MTE System } \\
\text { Costs, } \$ 10^{y}\end{array}$} \\
\hline Fractionation & - & - & - \\
\hline Vitrification & 0.53 & 0.49 & 0.45 \\
\hline Transportation & 0.29 & 0.26 & 0.21 \\
\hline Long-Term Storage & - & - & - \\
\hline Repository & 3.28 & 3.08 & 3.00 \\
\hline TOTAL SYSTEM & 4.10 & 3.83 & 3.66 \\
\hline \multicolumn{4}{|l|}{$\begin{array}{l}\text { Incremental Costs for } \\
\text { Shared Repository, } \$ 10^{9}\end{array}$} \\
\hline Vitrification & 0.53 & 0.49 & 0.45 \\
\hline Transportation & 0.29 & 0.26 & 0.21 \\
\hline Repository (a) & $\simeq 0.90$ & $\simeq 0.75$ & $\simeq 0.70$ \\
\hline TOTAL SYSTEM & $\sim 1.72$ & $\sim 1.50$ & $\sim 1.36$ \\
\hline
\end{tabular}

(a) Incremental repository costs vary with FHLW requirements. 
TABLE 5.19. Repository Emplacement Features and System Costs for Cs/Sr Waste at $1.73 \mathrm{ft}^{3} / \mathrm{MTE}$

\begin{tabular}{|c|c|c|c|c|}
\hline & & $\begin{array}{l}\text { imum } \mathrm{Ba} \\
\text { erature }\end{array}$ & & \\
\hline & 300 & 350 & & 400 \\
\hline Canister Diameter, ft & 0.89 & 0.98 & & 1.11 \\
\hline Canister Loading & & & & \\
\hline $\mathrm{kW}$ & 2.25 & 2.70 & & 3.48 \\
\hline MTE & 2.90 & 3.48 & & 4.48 \\
\hline Canister Pitch, m & 7.5 & 5.2 & & 6.0 \\
\hline $\begin{array}{l}\text { Canister Per } \\
50,000 \text { MTE, } 10^{3}\end{array}$ & 17.2 & 14.4 & & 11.2 \\
\hline Areal Heat Load, kW/acre & 52.0 & 90.0 & & 100.2 \\
\hline Repository Area, acres & & & & \\
\hline Single Purpose Repository & 1270 & 960 & & 920 \\
\hline Shared Repository & 740 & 430 & & 490 \\
\hline 50,000 MTE System Costs, $\$ 10^{9}$ & & & & \\
\hline Fractionation & - & - & - & \\
\hline Vitrification & 0.51 & 0.47 & & 0.44 \\
\hline Transportation & 0.30 & 0.28 & & 0.25 \\
\hline Long-Term Storage & - & - & - & \\
\hline Repository & 3.25 & 3.05 & & 3.00 \\
\hline TOTAL SYSTEM & 4.06 & 3.80 & & 3.69 \\
\hline
\end{tabular}


significant. To be conservative, the repository requirements and total system costs for the fractionation cases are all based on $2 \mathrm{ft}^{3} / \mathrm{MTE}$ for the $\mathrm{Cs} / \mathrm{Sr}$ waste and a $300^{\circ} \mathrm{C}$ maximum basalt temperature.

One of the alternatives for disposing of the cesium and strontium waste is to store it in a surface facility for a number of years before disposal. This case is represented in Table 5.20. In the table, optimum system cost for disposal of 10-year-old $\mathrm{Cs} / \mathrm{Sr}$ waste is compared with optimum system cost for disposal after an additional 50 years of storage. Largely because the added storage cost tends to offset the reduced repository costs, total costs for the storage case are not much lower than for the immediate disposal case. Thus, there is not a large incentive to delay disposal of the Cs/Sr waste. If a cost-of-money discount rate is applied, however, the repository costs are reduced and this alternative becomes more attractive.

\subsubsection{Minimum Cost Comparisons Without Bentonite Backfill}

A modification of the procedure described previously for determining the minimum cost configuration was used to determine minimum cost configurations for emplacement of HLW or FHLW canisters without a bentonite backfill. Since it had been determined that the minimum cost would always occur with the maximum waste concentration, i.e., minimum specific volume, this variable was fixed, leaving only canister size and pitch to be determined. Using data for canister emplacements without the bentonite backfill obtained from the heat transfer simulations discussed in Chapter 3, waste centerline temperature isotherms of $\mathrm{kW}$ per canister waste loadings versus canister diameter were plotted for three canister pitches at each of four waste centerline temperatures. The canister pitches were 2, 4 and 7 meters and the waste centerline temperatures were $100^{\circ}, 200^{\circ}, 300^{\circ}$ and $400^{\circ} \mathrm{C}$. Then, by also plotting in the same figure the maximum canister loading at the two alternative waste volumes for each disposal alternative, the intersections of these curves provided three canister sizes at maximum waste loadings at three different pitches for each centerline temperature. Total system costs were then calculated for each of these points and plotted against canister pitch, and from this plot the minimum system cost was determined. 
TABLE 5.20. Comparison of Repository Emplacement Features and System Costs for 10-year-old Cs/Sr Waste with 60Year-Aged Cs/Sr Waste at $1.73 \mathrm{ft}^{3} / \mathrm{MTE}$ with a $300^{\circ} \mathrm{C}$ Maximum Basalt Temperature

\begin{tabular}{|c|c|c|}
\hline & $\begin{array}{l}\text { 1-year-old } \\
\text { Cs/Sr Waste } \\
\end{array}$ & $\begin{array}{l}\text { 60-year-old } \\
\text { Cs/Sr Waste } \\
\end{array}$ \\
\hline Canister Diameter, ft & 0.89 & 1.7 \\
\hline \multicolumn{3}{|l|}{ Canister Loading } \\
\hline$k W$, final & 2.25 & 2.57 \\
\hline initial & - & 8.15 \\
\hline MTE & 2.90 & 10.5 \\
\hline Canister Pitch, m & 7.2 & 6.8 \\
\hline Canisters Per 50,000 MTE, $10^{3}$ & 17.2 & 4.8 \\
\hline Areal Heat Load, kW/acre & 52.0 & 65.5 \\
\hline \multicolumn{3}{|l|}{ Repository Area, acres } \\
\hline Single Purpose Repository & 1270 & 718 \\
\hline Shared Repository & 740 & 190 \\
\hline \multicolumn{3}{|l|}{50,000 MTE System Costs, $\$ 10^{9}$} \\
\hline Fractionation & - & - \\
\hline Vitrification & 0.51 & 0.27 \\
\hline Transportation & 0.30 & 0.22 \\
\hline Long-Term Storage & - & 0.62 \\
\hline Repository & 3.25 & 2.85 \\
\hline TOTAL SYSTEM & 4.06 & 3.96 \\
\hline \multicolumn{3}{|l|}{$\begin{array}{l}\text { Incremental Costs for Shared } \\
\text { Repository, } \$ 10^{9}\end{array}$} \\
\hline Vitrification & 0.51 & 0.27 \\
\hline Transportation & 0.30 & 0.22 \\
\hline Long-Term Storage & - & 0.62 \\
\hline Repository & $\simeq 0.90$ & $\simeq 0.30$ \\
\hline TOTAL SYSTEM & $\sim 1.71$ & $\sim 1.41$ \\
\hline
\end{tabular}


The canister loading relationships used for these determinations are shown in Figures 5.20, 5.21 and 5.22 for HLW, FHLW recycle case, and FHLW no-recycle case, respectively. The system cost calculation results at each of the intersections are presented in Tables $C .21$ through C.25, in Appendix C. As in the bentonite backfill cases, the canister size was limited to the larger of either a 0.5-ft-diameter canister or the canister size determined from the intersections on the canister loading plots.

The range of conditions evaluated without the bentonite backfill was not as large as in the bentonite backfill case, inasmuch as the effect of a 1600-acre repository was not considered and only a single minimum waste volume condition was evaluated for the FHLW no-recycle case. Neither was a comparison with HLW aging developed.

A summary comparison of total system costs for HLW and FHLW disposal without bentonite backfill is provided in Table 5.21. The FHLW disposal cases include the requirements for disposal of the $\mathrm{Cs} / \mathrm{Sr}$ component in a separate section of the same repository. These results are also plotted in Figure 5.23 to provide additional perspective. The cost relationships are similar to those found with the bentonite backfill. System costs for the HLW disposal are lower than FHLW disposal at the higher range of maximum waste centerline temperatures until the centerline temperature is reduced below $250^{\circ} \mathrm{C}$. At that point, the cost advantage begins to develop for the FHLW disposal and at the very low waste centerline temperatures; for example, at $100^{\circ} \mathrm{C}$ the advantage for the $H L W$ disposal is approximately a factor of two lower cost.

The system costs for the HLW disposal case rise quite slowly as the centerline temperature is reduced from $400^{\circ} \mathrm{C}$ to $300^{\circ} \mathrm{C}$, indicating that there may not be any great incentive for designing HLW emplacement to maximum temperature constraints if canister size and emplacement are optimized. As in the case where bentonite backfill is used, the fractionation concept offers the possibility of reducing the waste package temperatures at a relatively modest cost compared to the total disposal system cost.

ine totai repository area requirements for these cases are compared in Table 5.22. The relationship between the area requirements are generally comparable to the total system cost relationships. The very large area 


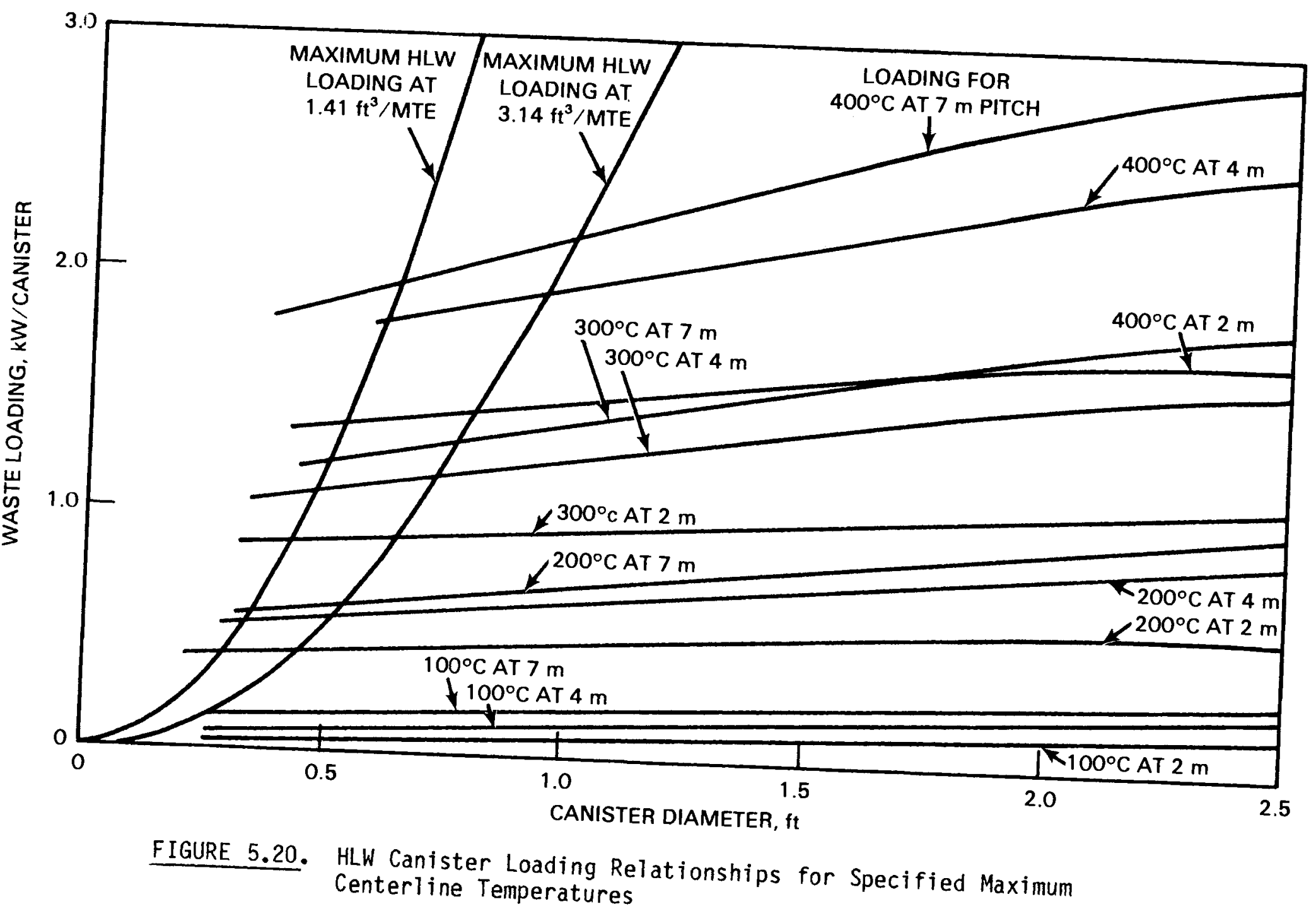




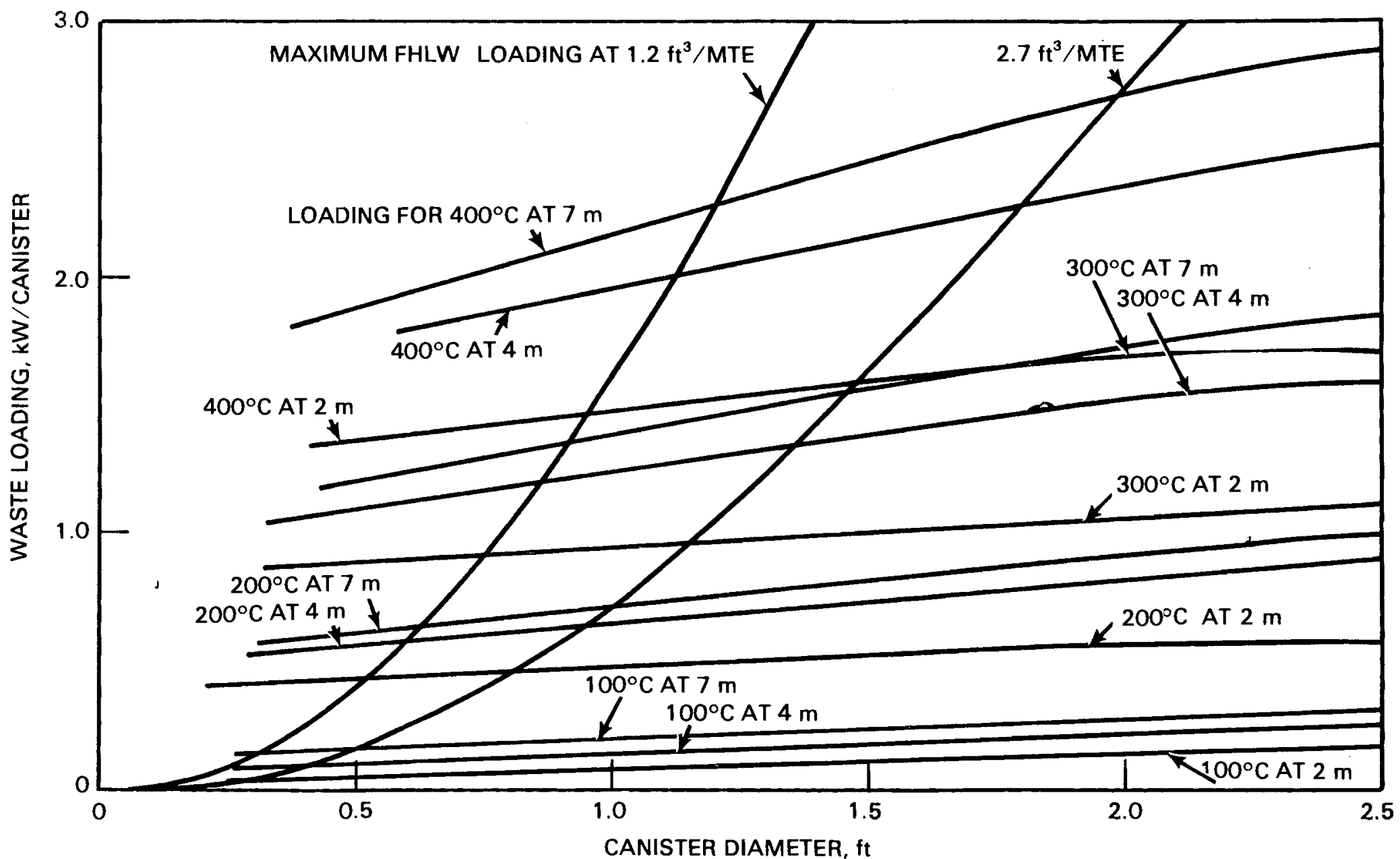

FIGURE 5.21. FHLW (recycle case) Loading Relationships for Specified Maximum Waste Centerline Temperatures 


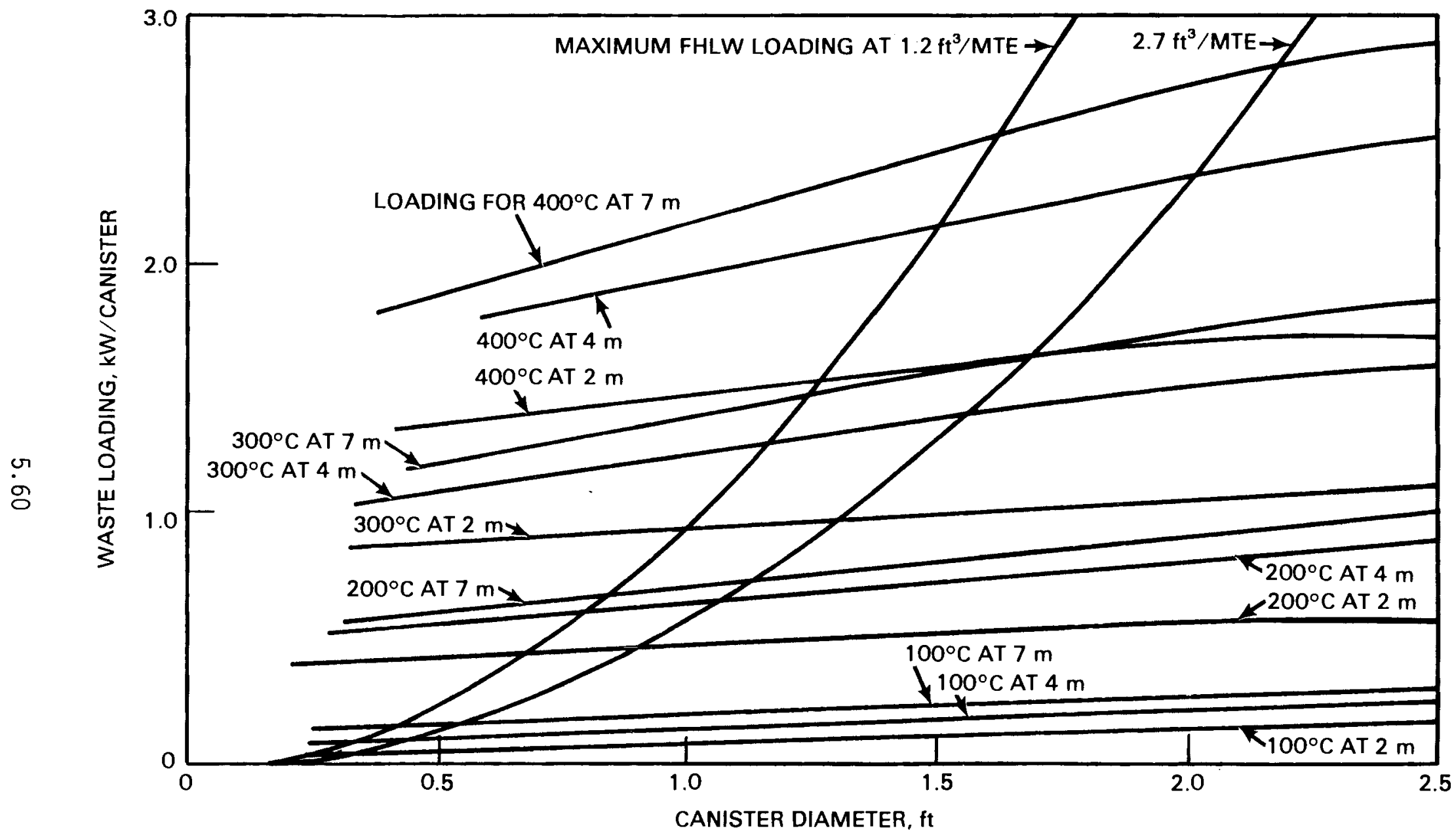

FIGURE 5.22. FHLW (no-recycle case) Loading Relationships for Specified Maximum Waste Centerline Temperatures 

TABLE 5.21. Comparison of Total System Costs for HLW and FHLW
Disposal Without Bentonite Backfi11, $\$ 10^{9}$

Maximum Centerline

Temperature, ${ }^{\circ} \mathrm{C}$

HLW

$$
1.41 \mathrm{ft}^{3} / \mathrm{MTE}
$$

$3.14 \mathrm{ft}^{3} / \mathrm{MTE}$

FHLW Recycle Case (a)

$1.20 \mathrm{ft}^{3} / \mathrm{MTE}$

$2.70 \mathrm{ft}^{3} / \mathrm{MTE}$

FHLW No-Recycle Case $^{(a)}$
100

200

300

400

24.0

8.3

$5.5 \quad 4.6$

24.0

8.5

$5.9 \quad 5.0$

11.7

6,9

6.2

5.9

11.7

7.1

6.46 .2

9.3

6.3

5.8

5.7

(a) The FHLW cases include the incremental costs for disposal of the Cs/Sr waste in the same repository.

requirement of 14,500 acres for achieving a $100^{\circ} \mathrm{C}$ waste centerline temperature with HLW disposal is not likely to be feasible. The 5,000-acre requirement for achieving a $100^{\circ} \mathrm{C}$ waste centerline temperature with the FHLW disposal is likewise questionable for a single repository. Both reasonable costs and reasonable area requirements appear achievable at maximum centerline temperatures on the order of $150^{\circ} \mathrm{C}$ with the FHLW disposal concept.

Additional details for the optimum repository emplacement features for HLW disposal are provided in Tables 5.23 and 5.24 for HLW waste volumes of 1.41 and $3.14 \mathrm{ft}^{3} /$ MTE, respectively. Similar information for the FHLW cases is provided in Tables 5.25 through 5.27. These last three tables also identify the incremental costs for the $\mathrm{Cs} / \mathrm{Sr}$ waste component disposal costs. 


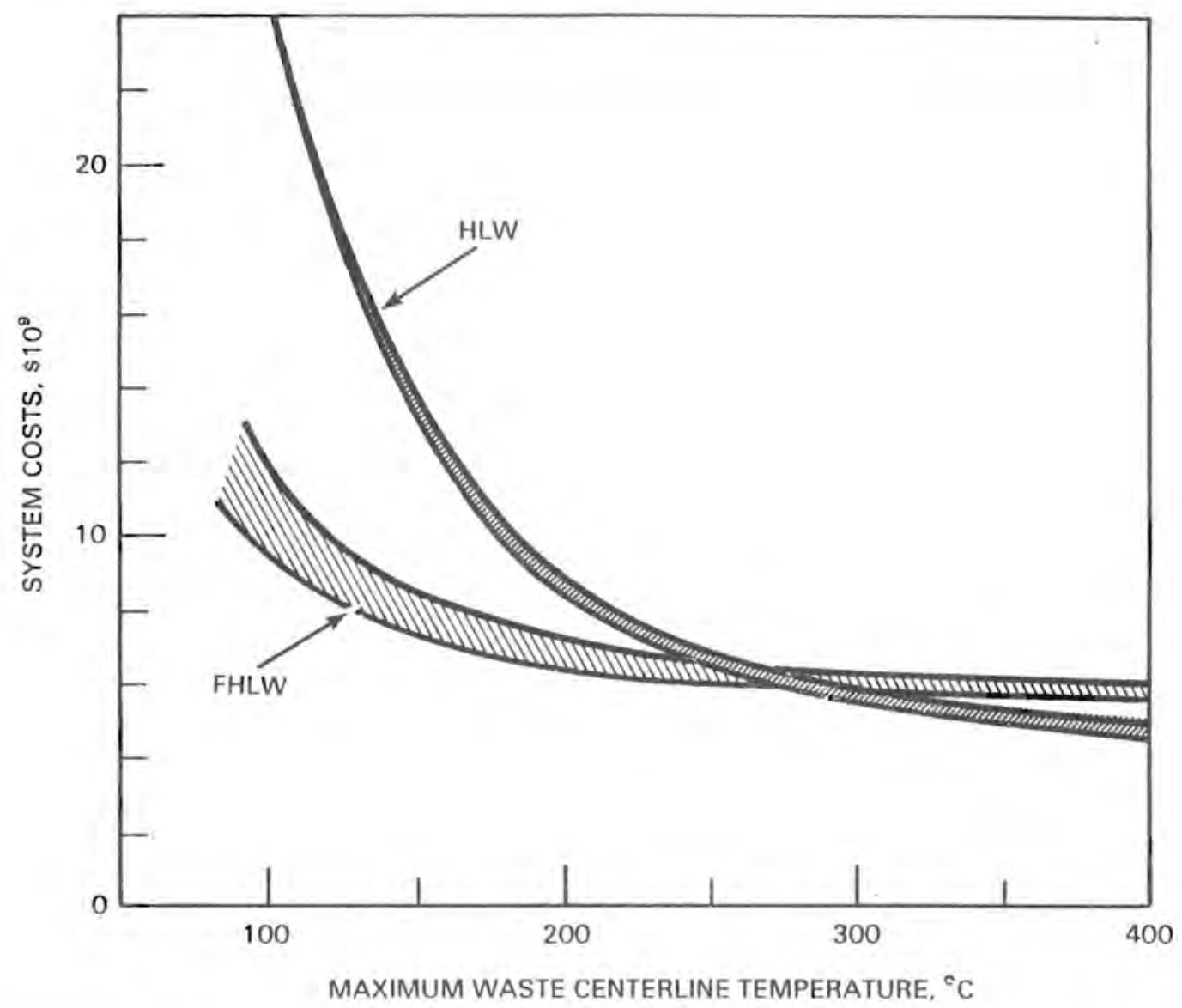

FIGURE 5.23. Total 50,000 MTE System Cost Comparison for HLW and Fractionated HLW Disposal Without Bentonite Backfill 
TABLE 5.22. Comparison of Total Repository Area Requirements for HLW and FHLW Without Bentonite Backfill Requirements, Acres

Maximum Waste Centerline

Temperature, ${ }^{\circ} \mathrm{C}$

$100 \quad 200 \quad 300 \quad 400$

HLW
$1.41 \mathrm{ft}^{3} / \mathrm{MTE}$
14,500
2,750
1,670
1,230
$3.14 \mathrm{ft}^{3} /$ MTE
$14,500 \quad 2,750 \quad 1,650 \quad 1,180$
FHLW Recycle Case ${ }^{(a)}$
$1.20 \mathrm{ft}^{3} / \mathrm{MTE}$
$5,050 \quad 1,640 \quad 1,520 \quad 1,410$
$2.70 \mathrm{ft}^{3} /$ MTE
$5,050 \quad 1,780 \quad 1,490 \quad 1,385$
FHLW No-Recycle Case $^{(a)}$
$1.20 \mathrm{ft}^{3} / \mathrm{MTE}$
$3,500 \quad 1,570 \quad 1,390 \quad 1,330$

(a) The FHLW cases include the incremental area required for disposal of the Cs/Sr waste in the same repository. 
TABLE 5.23. Repository Emplacement Features and System Costs for HLW at $1.41 \mathrm{ft}^{3} /$ MTE Without Bentonite Backfill

\begin{tabular}{|c|c|c|c|c|}
\hline & & $\begin{array}{l}\text { ximum } 0 \\
\text { Tempera }\end{array}$ & $\begin{array}{l}\text { terline } \\
\text { re, }{ }^{\circ} \mathrm{C}\end{array}$ & \\
\hline & 100 & 200 & 300 & 400 \\
\hline Canister Diameter, ft & 0.50 & 0.50 & 0.50 & 0.61 \\
\hline Canister Loading & & & & \\
\hline kW & 0.19 & 0.56 & 1.09 & 1.78 \\
\hline MTE & 0.18 & 0.52 & 1.01 & 1.65 \\
\hline Canister Pitch, m & 8.5 & 4.0 & 4.0 & 4.0 \\
\hline $\begin{array}{l}\text { Canisters Per } \\
50,000 \text { MTE, } 10^{3}\end{array}$ & 284 & 96.2 & 49.5 & 30.3 \\
\hline Areal Heat Load, kW/acre & 3.9 & 24.3 & 47.3 & 77.2 \\
\hline Repository Area, acres & 14,500 & 2,750 & 1,670 & 1,230 \\
\hline $\begin{array}{l}50,000 \text { MTE System } \\
\text { Costs, } \$ 10^{9}\end{array}$ & 24.0 & 8.3 & 5.5 & 4.6 \\
\hline
\end{tabular}

TABLE 5.24. Repository Emplacement Features and System Costs for HLW at $3.14 \mathrm{ft}^{3} /$ MTE Without Bentonite Backfill

\begin{tabular}{|c|c|c|c|c|}
\hline & & $\begin{array}{l}\text { ximum } \\
\text { Tempera }\end{array}$ & $\begin{array}{l}\text { Cerline } \\
\mathrm{e},{ }^{\circ} \mathrm{C}\end{array}$ & \\
\hline & 100 & 200 & 300 & 400 \\
\hline Canister Diameter, ft & 0.50 & 0.51 & 0.73 & 0.94 \\
\hline Canister Loading & & & & \\
\hline $\mathrm{kW}$ & 0.19 & 0.56 & 1.15 & 1.92 \\
\hline MTE & 0.18 & 0.52 & 1.06 & 1.78 \\
\hline Canister Pitch, m & 8.5 & 4.0 & 4.0 & 4.0 \\
\hline $\begin{array}{l}\text { Canisters Per } \\
50,000 \text { MTE, } 10^{3}\end{array}$ & 284 & 96.2 & 47.2 & 28.1 \\
\hline Areal Heat Load, kW/acre & 3.9 & 24.3 & 49.9 & 83.2 \\
\hline Repository Area, acres & 14,500 & 2,750 & 1,620 & 1,180 \\
\hline $\begin{array}{l}50,000 \text { MTE System } \\
\text { Costs, } \$ 10^{9}\end{array}$ & 24.0 & 8.5 & 5.9 & 5.0 \\
\hline
\end{tabular}


TABLE 5.25. Repository Emplacement Features and System Costs for FHLW (recycle case) at $1.20 \mathrm{ft}^{3} /$ MTE Without Bentonite Backfill

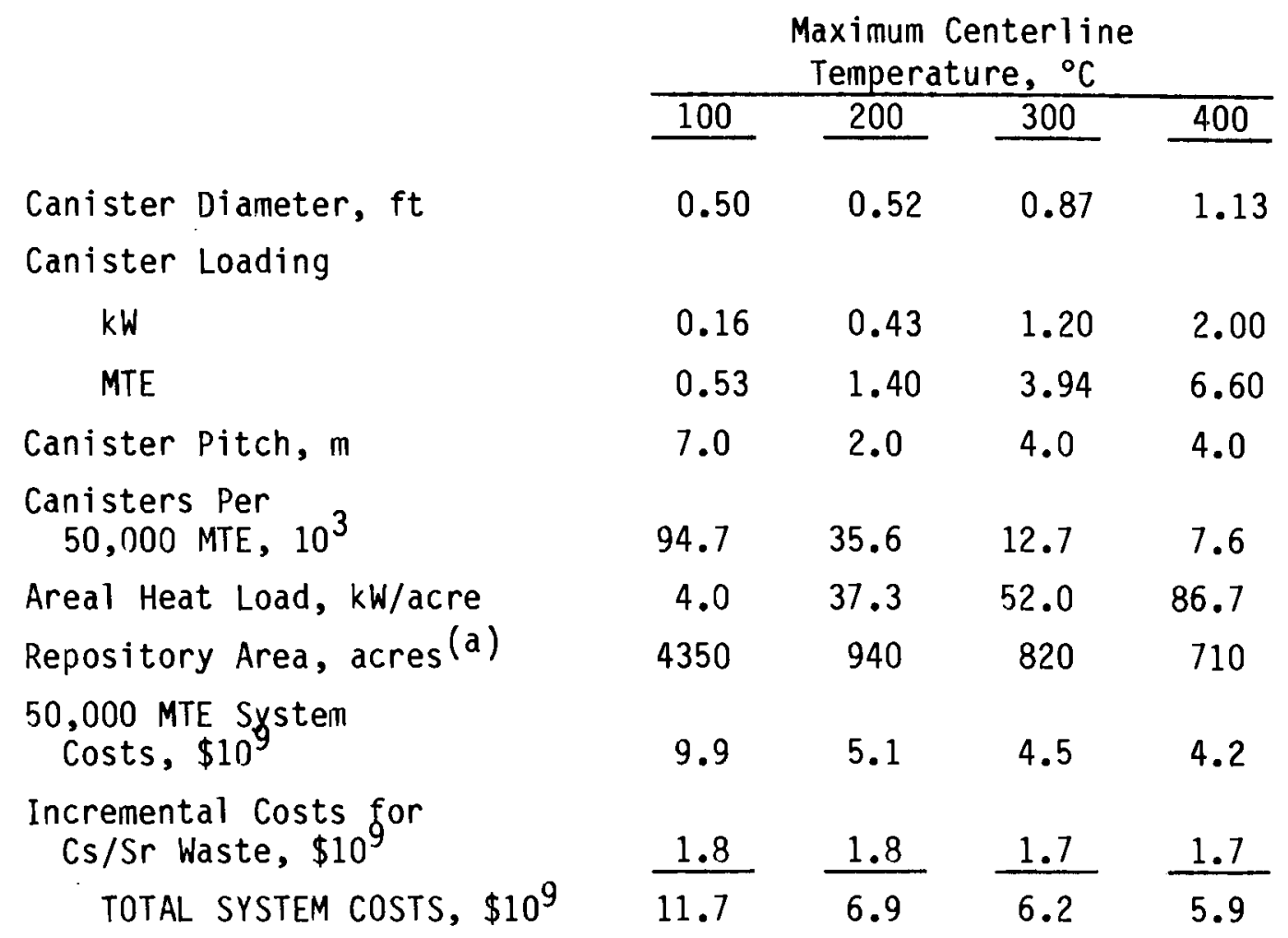

(a) An additional 700 acres of emplacement area is required for the $\mathrm{Cs} / \mathrm{Sr}$ waste if placed in the same repository. For details of optimum $\mathrm{Cs} / \mathrm{Sr}$ waste characteristics, see Table 5.18 , Column 1. 
TABLE 5.26. Repository Emplacement Features and System Costs for FHLW (recycle case) at $2.70 \mathrm{ft}^{3} /$ MTE Without Bentonite Backfill

\begin{tabular}{|c|c|c|c|c|}
\hline & & $\begin{array}{l}\text { aximum } \\
\text { Temper }\end{array}$ & $\begin{array}{l}\text { terlir } \\
\mathrm{re},{ }^{\circ} \mathrm{C}\end{array}$ & \\
\hline & 100 & 200 & 300 & 400 \\
\hline Canister Diameter, ft & 0.5 & 0.94 & 1.36 & 1.80 \\
\hline Canister Loading & & & & \\
\hline $\mathrm{kW}$ & 0.16 & 0.63 & 1.34 & 2.26 \\
\hline MTE & 0.53 & 2.08 & 4.42 & 7.46 \\
\hline Canister Pitch, m & 7.0 & 4.0 & 4.0 & 4.0 \\
\hline $\begin{array}{l}\text { Canisters Per } \\
50,000 \text { MTE, } 10^{3}\end{array}$ & 94.7 & 24.0 & 11.3 & 6.7 \\
\hline Areal Heat Load, kW/acre & 4.0 & 27.3 & 58.1 & 98.0 \\
\hline Repository Area, acres(a) & 4350 & 1080 & 790 & 685 \\
\hline $\begin{array}{l}50,000 \text { MTE System } \\
\text { Costs, } \$ 10^{9}\end{array}$ & 9.9 & 5.3 & 4.7 & 4.5 \\
\hline $\begin{array}{l}\text { Incremental Costs for } \\
\text { Cs/Sr Waste, } \$ 10^{9}\end{array}$ & 1.8 & 1.8 & 1.7 & 1.7 \\
\hline TOTAL SYSTEM COSTS, $\$ 10^{9}$ & 11.7 & 7.1 & 6.4 & 6.2 \\
\hline
\end{tabular}

(a) An additional 700 acres of emplacement area is required for the $\mathrm{Cs} / \mathrm{Sr}$ waste if placed in the same repository. For details of optimum Cs/Sr waste characteristics, see Table 5.18, Column 1. 
TABLE 5.27. Repository Emplacement Features and System Costs for FHLW (no-recycle case) at $1.20 \mathrm{ft}^{3} /$ MTE Without Bentonite Backfi11

\begin{tabular}{|c|c|c|c|c|}
\hline & & $\begin{array}{l}\text { aximum } \\
\text { Tempera }\end{array}$ & $\begin{array}{l}\text { terlin } \\
\text { re, }{ }^{\circ} \mathrm{C} \\
\end{array}$ & \\
\hline & 100 & 200 & 300 & 400 \\
\hline Canister Diameter, ft & 0.50 & 0.80 & 1.16 & 1.50 \\
\hline Canister Loading & & & & \\
\hline $\mathrm{kW}$ & 0.16 & 0.61 & 1.28 & 2.14 \\
\hline MTE & 0.89 & 3.39 & 7.11 & 11.9 \\
\hline Canister Pitch, m & 7.0 & 4.0 & 4.0 & 4.0 \\
\hline $\begin{array}{l}\text { Canisters Per } \\
50,000 \text { MTE, } 10^{3}\end{array}$ & 56.2 & 14.7 & 7.0 & 4.2 \\
\hline Areal Heat Load, kW/acre & 4.0 & 26.4 & 55.5 & 92.8 \\
\hline Repository Area, acres (a) & 2800 & 870 & 690 & 630 \\
\hline $\begin{array}{l}50,000 \text { MTE System } \\
\text { Costs, } \$ 10^{9}\end{array}$ & 7.2 & 4.6 & 4.1 & 4.0 \\
\hline $\begin{array}{l}\text { Incremental Costs for } \\
\text { Cs/Sr Waste, } \$ 10^{9}\end{array}$ & 2.1 & 1.7 & 1.7 & 1.7 \\
\hline TOTAL SYSTEM COSTS, $\$ 10^{9}$ & 9.3 & 6.3 & 5.8 & 5.7 \\
\hline
\end{tabular}

(a) An additional 700 acres of emplacement area is required for the $\mathrm{Cs} / \mathrm{Sr}$ waste if placed in the same repository. For details of optimum Cs/Sr waste characteristics, see Table 5.18, Column 1. 



\subsection{RADIATION RISK ANALYSIS}

Both near- and long-term radiation risks for the waste management alternatives are compared in this chapter. The near-term risks for both normal operations and potential accidents are evaluated for waste treatment, transportation and repository operations in Section 6.1. The near-term risks of storage for high-level waste (HLW) and cesium/strontium ( $\mathrm{CS} / \mathrm{Sr}$ ) waste are compared in Section 6.2. The long-term risks of geologic disposal are compared in Section 6.3 .

\subsection{NEAR-TERM RADIOLOGICAL RISK}

Near-term risk analysis comparisons are developed in this section for the three alternative disposal options for canister sizes, canister loadings, and repository loadings selected on the basis of cost analysis results. The nearterm risk analysis is concerned primarily with relative risk implications for the processing, transportation, and repository disposal of the different canisters and waste loadings for the three basic alternatives.

The near-term risk of alternative cases is analyzed in terms of radiation dose to the public. Doses to the public from waste management practices are presented for potential releases associated with routine operations and accidents for individual facilities and transportation systems. Doses to the public from these releases would be expected to arise from inhalation of radionuclides, from direct radiation, and from ingestion of food products. For normal operations, the doses are expressed in terms of a regional population dose. For accident scenarios, the doses are calculated in terms of the dose to the maximum-exposed individual. Radiological effects to the maximum-exposed individual and the regional population are calculated based on the methods and assumptions outlined in Section D.1 of Appendix D (Volume 2).

\subsubsection{Population Dose for System Alternatives During Normal Operations}

During normal operations of the waste management facilities, the only exposure patinway to the public is via airborne effluents; there are no planned releases to the ground or water. For transportation of radioactive wastes under normal circumstances, no radioactive materials will be released via any 
pathway. However, individuals will receive very small doses from the direct radiation from passing rail shipments.

The estimated whole-body population doses for each of the major system components in each of the three alternative options are compared in Table 6.1. Two cases are shown for each alternative: a case where canister size and waste concentrations are optimized for a $100^{\circ} \mathrm{C}$ maximum bentonite temperature and a case optimized for a $250^{\circ} \mathrm{C}$ maximum bentonite temperature. The comparisons are based on a regional population whole-body dose per 50,000 metric tons equivalent (MTE) of spent fuel. Relatively small decreases in the total population dose are exhibited for the fractionation and the agedHLW cases compared to the reference HLW cases.

Table 6.1 shows the regional population whole-body dose for the vitrification, transportation and repository phases in man-rem per 50,000 MTE for the cases selected on the basis of the cost analysis results. Doses from the processing phase and the disposal phase are equivalent for the three waste disposal alternatives and only minor, but not significant differences, occur in whole-body dose for the transportation phase.

Integrated 70-year whole-body dose from operation of the HLW vitrification facility was calculated to be about 700 man-rem. Doses from the vitrification process are estimated to be about the same for all three alternatives and represent over 95\% of the total dose for the processing, transportation, and repository phases.

On the basis of maximum bentonite temperature, the transportation doses are only slightly different for the three cases. There are no significant differences between the reference $H L W$ cases and the fractionation cases. Doses from transportation of aged-HLW are lower by a factor of two due to the reduction in the radioactivity levels of the material shipped, which results in the lower population doses.

The calculated total population dose does not differ by more than about $2 \%$ in the three basic alternatives, resulting mainly from the differences in the doses from the transportation phase. 
TABLE 6.1. Whole-Body Population Dose (Regional Population)(a)

70-Year Whole-Body Dose (man-rem/50,000 MTE)

\begin{tabular}{|c|c|c|c|c|c|c|}
\hline \multirow{3}{*}{$\frac{\text { Type of Waste }}{\text { Maximum Bentonite Temperature, }{ }^{\circ} \mathrm{C}}$} & \\
\hline & \multicolumn{2}{|c|}{ HLW } & \multicolumn{2}{|c|}{$\begin{array}{l}\mathrm{FHLW}+\mathrm{Cs} / \mathrm{Sr} \\
\text { Fractionation }\end{array}$} & \multicolumn{2}{|c|}{ Aged-HLW } \\
\hline & 100 & 250 & 100 & 250 & 100 & 250 \\
\hline \multicolumn{7}{|l|}{ Waste Proce'ssing } \\
\hline HLW Vitrification & $6.93 \times 10^{2}$ & $6.93 \times 10^{2}$ & - & -- & $6.93 \times 10^{2}$ & $6.93 \times 10^{2}$ \\
\hline Cs/Sr Separation & -- & - & Negligible $e^{(b)}$ & Negligible & -- & - \\
\hline FHLW Vitrification & -- & -- & $6.93 \times 10^{2}$ & $6.93 \times 10^{2}$ & -- & -- \\
\hline Cs/Sr Waste Vitrification & -- & - & $5.00 \times 10^{-5}$ & $5.00 \times 10^{-5}$ & -- & -- \\
\hline Storage (50 years) & -- & - & - & -- & $2.0 \times 10^{-5}$ & $2.0 \times 10^{-5}$ \\
\hline \multicolumn{7}{|l|}{ Transportation } \\
\hline HLW to Repository & $1.40 \times 10^{1}$ & $1.68 \times 10^{1}$ & -- & -- & -- & -- \\
\hline FHLW to Repository & - & -- & $1.30 \times 10^{0}$ & $1.40 \times 10^{0}$ & -- & -- \\
\hline $\mathrm{Cs} / \mathrm{Sr}$ to Repository & - & -- & $1.55 \times 10^{1}$ & $1.55 \times 10^{1}$ & -- & -- \\
\hline Aged-HLW to Repository & -- & -- & -- & -- & $8.0 \times 10^{0}$ & $8.0 \times 10^{0}$ \\
\hline \multicolumn{7}{|l|}{ Disposal } \\
\hline$H L W$ & Negligible & Negligible & -- & -- & -- & - \\
\hline FHLW & -- & - & Negligible & Negligible & -- & -- \\
\hline $\mathrm{Cs} / \mathrm{Sr}$ & -- & - & Negligible & Negligible & -- & -- \\
\hline Aged-HLW & -- & -- & - & -- & Negligible & Negligible \\
\hline $\begin{array}{l}\text { TOTAL (man-rem per } 50,000 \text { MTE } \\
\text { processed for repository) }\end{array}$ & $7.07 \times 10^{2}$ & $7.10 \times 10^{2}$ & $7.10 \times 10^{2}$ & $7.10 \times 10^{2}$ & $7.01 \times 10^{2}$ & $7.01 \times 10^{2}$ \\
\hline
\end{tabular}

(a) Based on regional population of $2 \times 10^{6}$.

(b) Negligible indicates less than $10^{-5}$ man-rem/50,000 MTE. 
It should be noted that these doses are an insignificant fraction of the total dose received from background radiation over the same time period that the waste is processed, shipped, and put into storage. The regional population would receive about $1.4 \times 10^{7}$ man-rem from naturally occurring sources over the same time period.

\subsubsection{Radiological Impact in the Event of Accidents}

Accidents which could result in the release of radioactivity during the processing, transportation, and disposal of HLW have been analyzed to determine if there are any significant differences between the alternative study cases for the reference HLW, fractionated waste, and aged-HLW. The process by which accidents are selected for analysis is described in DOE (1980) as an umbrella source-term approach. This approach is used to evaluate near-term radiological risks at waste management facilities, and is discussed in detail in Section D.1 of Appendix D.

Accidents or other events associated with waste solidification by vitrification, transportation, and repository storage that might be expected to lead to releases of radioactive material have been identified in DOE (1979b). Accidents analyzed in detail were chosen on the basis of the greatest probability of occurrence and the greatest radiological consequences. It is assumed that if these accidents were to occur, cleanup measures would be taken to restore the facility to a safe condition. The accidents for the vitrification facility, transportation systems, and the repository selected for analysis using the umbrella source-term approach are listed in Table 6.2.

\section{TABLE 6.2. Umbrella Source-Term Accidents}

Process

Vitrification

Transportation by Rail

Repository Facility (Operational Phase)
Accident Severity Level Description

Moderate - Failure of off-gas filter or scrubber Severe - None identified

Minor - Train derailment and fire involving HLW cask Severe - HLW cask subjected to severe impact and fire Moderate - Canister drop down mine shaft Severe - None identified 
For waste solidification by vitrification, a process off-gas cleanup system failure was judged to be the most severe and was taken as the umbrella source-term accident. Seventy-year dose commitments were calculated for the maximum-exposed individual. The doses to the maximum-exposed individual from this accident are shown in Table 6.3.

Several minor accidents associated with rail transport of HLW were identified that could be expected to lead to release of radioactive materials. Scenarios for these accidents are provided in DOE (1979a). Accidents postulated to release radioactive material in amounts larger than those released by minor accidents are classified as moderate and severe accidents. The severe transportation accident analyzed for this study (HLW cask subjected to severe impact and fire) results in a ground-level release which lasts for about 15 minutes. Doses to the maximum-exposed individual for the 70-year dose commitment for the minor and severe transportation accidents are also given in Table 6.3.

A canister drop accident of vitrified HLW down a mine shaft would be the worst-case accident for a repository. The dose to the maximum-exposed individual from a canister drop accident under the study cases is shown in Table 6.3. The 70-year whole-body dose commitment to the maximum-exposed individual for the vitrified waste canister drop accident was calculated to be on the order of $10^{-5}$ to $10^{-6}$ rem. This dose is very small compared to the radiation dose of about 2 rem the individual would have received from naturally occurring sources over the period of a repository operation.

\section{1 .3 Conclusions}

The results of the near-term radiological risk analysis show that there are only small differences in the regional population dose and the dose to the maximum-exposed individual for the three alternative cases covered in this study. For normal operations, the difference between the alternatives is only about $2 \%$ of the total regional population dose and is not significant. 
TARLE 6.3. 70-Year Whole-Rody Dose Commitment to Maximum-Fxposed Individual (rem)

\begin{tabular}{|c|c|c|c|c|c|c|}
\hline Type of Waste & \multicolumn{2}{|c|}{ HLW } & \multicolumn{2}{|c|}{$\begin{array}{l}\mathrm{FHLW}+\mathrm{Cs} / \mathrm{Sr} \\
\text { Fractionation }\end{array}$} & \multicolumn{2}{|c|}{ Aged-HLW(a) } \\
\hline Maximum Bentonite Temperature, ${ }^{\circ} \mathrm{C}$ & 100 & 250 & 100 & 250 & 100 & 250 \\
\hline Process/Accident Description & & & & & & \\
\hline Vitrification Plant & & & & & & \\
\hline Moderate - Filter Failure & $2.4 \times 10^{-4}$ & $2.4 \times 10^{-4}$ & $\begin{array}{l}\text { FHLW } \\
1.9 \times 10^{-5} \\
\text { Cs/Sr }(5) \\
2.2 \times 10^{-4}\end{array}$ & $\begin{array}{l}\text { FHLW } \\
1.9 \times 10^{-5} \\
\text { Cs/Sr } \\
2.2 \times 10^{-4}\end{array}$ & $2.4 \times 10^{-4}$ & $2.4 \times 10^{-4}$ \\
\hline Transportation & & & & & & \\
\hline Minor - Train Derailment & -- & -- & $\begin{array}{l}\text { FHLW } \\
3.0 \times 10^{-7} \\
\mathrm{Cs} / \mathrm{Sr}(5) \\
3.7 \times 10^{-6}\end{array}$ & $\begin{array}{l}\text { FHLW } \\
3.0 \times 10^{-7} \\
\text { Cs } / \mathrm{Sr} \\
3.7 \times 10^{-6}\end{array}$ & -- & -- \\
\hline Severe - HLW Case Impact and Fire & $1.1 \times 10^{0}$ & $5.2 \times 10^{0}$ & $\begin{array}{l}\text { FHLW } \\
4.0 \times 10^{-1} \\
\mathrm{Cs} / \mathrm{Sr}(5) \\
4.7 \times 10^{0}\end{array}$ & $\begin{array}{l}\text { FHLW } \\
4.0 \times 10^{-1} \\
\mathrm{Cs} / \mathrm{Sr} \\
4.7 \times 10^{0}\end{array}$ & $3.0 \times 10^{-1}$ & $3.0 \times 10^{-1}$ \\
\hline Repository & & & & & & \\
\hline Moderate - Canister Drop & $1.8 \times 10^{-6}$ & $9.8 \times 10^{-6}$ & $\begin{array}{l}\text { FHLW } \\
7.2 \times 10^{-7} \\
\mathrm{Cs} / \mathrm{Sr}(5)^{-6} \\
8.7 \times 10^{-6}\end{array}$ & $\begin{array}{l}\text { FHLW } \\
1.0 \times 10^{-6} \\
\mathrm{Cs} / \mathrm{Sr} \\
8.7 \times 10^{-6}\end{array}$ & $6.8 \times 10^{-7}$ & $6.8 \times 10^{-7}$ \\
\hline
\end{tabular}

(a) Aged-HLW is assumed to be stored for fifty years.

(b) Doses from $\mathrm{Cs} / \mathrm{Sr}$ fraction are for $300^{\circ} \mathrm{C}$ temperature in basalt (there is no bentonite for $\mathrm{Cs} / \mathrm{Sr}$ ). 
For accidents at vitrification facilities, accidents during transportation, and accidents at the waste disposal facility, the following conclusions can be drawn.

- For vitrification facilities, there are no significant differences in the three alternatives.

- For severe accidents, during the transportation phase, the near-term safety analysis showed that that maximum-exposed individual dose varied from about 1 rem to 5 rem for the three alternative cases. Although the doses are larger than the permissible annual occupational exposure, the dose level is not expected to result in any serious effects for the exposed individual.

- For the canister drop accident, all the maximum-exposed individual doses are small (on the order of $1 \times 10^{-6}$ to $1 \times 10^{-5} \mathrm{rem}$ ).

In summary, there are not significant differences between any of the three cases analyzed on the basis of the near-term risk analysis. Comparison of the alternatives, on the basis of canister sizes and waste concentrations optimized for specified maximum bentonite temperature, shows that there are no significant differences between whole-body population dose estimates for either normal operations or for maximum-exposed individual doses from accidents.

\subsection{INTERIM STORAGE RADIOLOGICAL RISK $(\mathrm{a})$}

The purpose of this discussion is to identify any storage impacts associated with either a waste management alternative that separates $\mathrm{Cs} / \mathrm{Sr}$ from HLW, disposes of the fractionated HLW at time zero, and disposes of the Cs/Sr after 50 years of storage (referred to here as Alternative A); or a waste management alternative that ages $H L W$ for 50 years prior to disposal (referred to here as Alternative $B$ ). The reference storage facility assumed in this discussion is the sealed storage cask concept in DOE/ET-0028, Section 5.4.2 (DOE 1979a). Assumptions regarding facility operation and accident conditions are those detailed in DOE/ET-0029, Sections 8.1.3 and 8.1.4 (DOE 1979b).

(a) Further detail on The material presented in this section is provided in Section 0.2 of Appendix D. 
Specifically, two conditions are addressed in this section: 1) a canister failure in a receiving cell, and 2) facility emissions from normal operations (i.e., from concentration of secondary wet wastes).

\subsubsection{Cell Handling Failure}

The analysis in DOE (1979b) indicates that only a canister failure in the receiving cell would result in release of radioactive material to the environment. Using assumptions outlined in Section D.2 of Appendix D, 70-year bone doses to a maximum-exposed individual were estimated as shown in Table 6.4. The values in Table 6.4 can be considered as the expected impact of a cell handling failure as they incorporate a frequency of failure estimate and the number of canisters associated with each alternative into the calculation.

The doses in Table 6.4 are believed small enough to be insignificant. The slight difference in the doses between Alternative $A$ and Alternative $B$ is due to the presence of more ${ }^{244} \mathrm{Cm}$ in aged-HLW than in Cs/Sr waste.

TABLE 6.4. Impacts of Cell Handling Failure (rem)

\begin{tabular}{|c|c|}
\hline Alternative & $\begin{array}{c}70-Y e a r \\
\text { Bone Dose }\end{array}$ \\
\hline$A-1(a)$ & $1 \times 10^{-9}$ \\
\hline$A-2$ & $1 \times 10^{-9}$ \\
\hline B & $4 \times 10^{-10}$ \\
\hline
\end{tabular}

(a) The difference between $A-1$ and A-2 is due to the canister loading (i.e., 0.627 and 3.66 MTE/canister) assumed.

\subsubsection{Process Effluents}

It is expected that small amounts of radionuclides will be released to the biosphere during normal operation of a storage facility. It is assumed in DOE (1979a) that the controlling release occurs during secondary wet waste concentration. Using assumptions outlined in Section D.2 of Appendix D, 70-year 
lifetime whole-body doses to a regional population of two million were estimated as shown in Table 6.5 and are believed small enough to be insignificant. After rounding to one significant figure, there are no differences between the values in Table 6.5 .

\section{TABLE 6.5. 70-Year Lifetime Whole-Body Luse to Regional Population from Process Effluents}

\begin{tabular}{|c|c|}
\hline Alternative & man-rem \\
\hline A-1 & $2 \times 10^{-5}$ \\
\hline$A-2$ & $2 \times 10^{-5}$ \\
\hline B & $2 \times 10^{-5}$ \\
\hline
\end{tabular}

\subsection{LONG-TERM RADIOLOGICAL RISK}

The objectives of this section are: 1) to identify any long-term radiological risk trade-offs between repository disposal of vitrified HLW (reference case) and repository disposal of vitrified FHLW plus separated Cs/Sr (Alternative A) or vitrified HLW that has been aged (Alternative B); and 2) to determine the influence on long-term safety of varying canister sizes, canister spacing, and waste loading. For perspective, estimated concentrations of radionuclides in ground water from a hypothetical faulting event are compared to NRC radionuclide concentration guides (NRC 1981a). In addition, estimated releases of radionuclides to the environment from a hypothetical human intrusion event are compared to draft Environmental Protection Agency (EPA 1982) guidelines.

The kinds of release mechanisms that could reduce the effectiveness of a repository are addressed in Section 6.3.1. EPA (1982) guidelines, NRC (1981b) criteria that will be used to implement the EPA guidelines, and NRC radionuclide concentration guides are described in Section 6.3.2, which also presents a discussion on how these guides and criteria are used to assess expected repository performance. Natural events or processes at a geologic repository and impacts associated with a naturally induced repository breach event are presented in Section 6.3.3. Human intrusion into a repository and impacts associated with that hypothetical event are discussed in Section 6.3.4. 


\subsubsection{Radionuclide Release Mechanisms}

Successful isolation of radioactive waste from the biosphere in repositories far below the earth's surface in geologic formations is believed to be achievable for periods of thousands of years (DOE 1980). Once a repository is filled with radioactive waste and sealed, the probability for any release, let alone a release exceeding draft EPA and NRC guidelines is believed to be small (DOE 1980). Radionuclides could hypothetically only reach the accessible environment by the following repository breach events or sequences:

1. exposure of the repository to the surface environment following large catastrophic events that remove the protective rock mass surrounding the waste (e.g., impact of a meteorite or nuclear weapon)

2. continuous entry of volumes of water causing dissolution and transport of waste radionuclides by ground water to an accessible body of water following a faulting or seismic event

3. removal of the waste through mining activities (e.g., mineral exploration and/or exploitation).

The probability of a repository breach event occurring as a result of a meteorite is estimated by evaluating the frequency of these events in the past (i.e., a meteorite of sufficient size and energy to penetrate beyond 600 to $1,000 \mathrm{~m}$ below the earth's surface) and has been reported to range from $3 x$ $10^{-11} / \mathrm{yr}$ to $2 \times 10^{-13} / \mathrm{yr}$ (Wallace et al. 1980). The likelihood of nuclear explosion is highly indeterminate. However, if such an event occurs, the results would probably be so devastating, even in the absence of a repository, that further consideration with respect to repository failure seems unwarranted. It is generally believed that the probability of such catastrophic events is extremely small (DOE 1980).

The second repository breach event, involving ground-water transport, results from a combination of events that create a driving force for ground water to enter and then exit the repository. This mechanism is generally assumed to represent the only natural event capable of transporting radionuclides from the repository. The probability of an event providing a source of water, a pathway to the waste, and a pathway from the repository located approximately 600 to $1,000 \mathrm{~m}$ below ground to an accessible body of water is 
smal1 (DOE 1980). Impacts of a repository breach event representative of this second type are described in Section 6.3.3.

The Department of Energy (DOE) intends to minimize the occurrence of the third repository breach event, removal of waste through mining activity, by incorporating resource potential into the criteria for siting a geologic repository (DOE 1982). However, it is recognized that quantitative predictions regarding the behavior of future societies are difficult to make. For this reason, impacts of an inadvertent human intrusion event are discussed in Section 6.3.4.

\subsubsection{Application of Regulations}

Draft EPA standards (1982) and proposed NRC criteria (1981b) are presented in Tables 6.6 and 6.7. These standards and criteria are used as a reference to compare performance of example repository systems under hypothetical failure conditions. The draft EPA standards are stated as cumulative release limits to the accessible environment for 10,000 years after disposal. The release limits are normalized on a 1,000 MTE basis for spent fuel and HLW. For transuranic (TRU) waste, the same limits apply to a normalized value of $3 \times 10^{6} \mathrm{Ci}$ of TRU. The release limits are based on a single radionuclide being released. For release of multiple radionuclides, the sum of the ratios of the individual radionuclide releases divided by the respective cumulative release limits may not exceed one. These limits apply to the occurrence of reasonably foreseeable events (i.e., probability $>0.01$ in 10,000 years). Allowable releases resulting from very unlikely events (i.e., probability $<0.01$ but $>0.0001$ in 10,000 years) are ten times the quantities in Table 6.6.

The accessible environment is defined by EPA as land and water surfaces, atmosphere, and underground formations greater than $10 \mathrm{~km}$ from the repository boundary (which might provide ground water for human consumption). A groundwater supply considered part of the accessible environment is an aquifer that provides usable quantities of water with a total dissolved solids (TDS) content of less than $10 \mathrm{~g} / \mathrm{L}$. However, the draft disposal standards do not limit releases to ground water that is within $10 \mathrm{~km}$ of the repository boundary. 
TABLE 6.6. Draft Environmental Protection Agency Cumulative Release Limits to the Accessible Environment for 10,000 Years After Repository Closure (EPA 1982)

\section{Radionuclide}

${ }^{241} \mathrm{Am}$
${ }^{243} \mathrm{Am}$
${ }^{14} \mathrm{C}$
${ }^{135} \mathrm{Cs}$
${ }^{137} \mathrm{Cs}$
${ }^{237} \mathrm{~Np}$
${ }^{238} \mathrm{Pu}$
${ }^{239} \mathrm{Pu}$
${ }^{240} \mathrm{Pu}$
${ }^{242} \mathrm{Pu}$
$226 \mathrm{Ra}$
${ }^{90} \mathrm{Sr}$
$99 \mathrm{TC}$
${ }^{126} \mathrm{Sn}$
Any other alpha-emitting
radionuclide
Any other radionuclides that
do not emit alpha particles

Release Limit Ci/1000 MTE

$$
\begin{array}{r}
10 \\
4 \\
200 \\
2,000 \\
500 \\
20 \\
400 \\
100 \\
100 \\
100 \\
3 \\
80 \\
2,000 \\
80 \\
10
\end{array}
$$

500

\section{TABLE 6.7. Proposed Nuclear Regulatory Commission} Performance Objectives (NRC 1981b)

- Waste Package Containment

- Engineered System Release Rate

- Geology and Hydrology

- Retrievability
1,000 yr

$1.0 \times 10^{-5} / \mathrm{yr}$ following $1,000 \mathrm{yr}$ package containment

1,000 yr ground-water travel time to the accessible environment

50 yr following completion of emplacement 
The proposed NRC technical criteria being developed to implement the draft EPA standards for releases to the accessible environment are based on performance objectives for individual components of the repository system. Acceptable locations for a repository require a minimum 1,000-year travel time for ground water from the repository boundary to the accessible environment. These travel times are determined by a combination of field, laboratory, and analytical techniques. Since the waste package is also required to contain the waste for 1,000 years, the first pulse of radionuclides that reach the accessible environment under the proposed design criteria would not occur until approximately 2,000 years after closure. In addition, the waste package should be designed to 1 imit the rate of release to $1.0 \times 10^{-5}$ fraction per year following the 1,000-year containment period.

Another set of criteria used to evaluate the estimated radionuclide release to ground water is radionuclide concentration guide (RCG) values reported in 10 CFR 20 Appendix B, Table 2 (NRC 1981a). These RCG values were developed for application to water sources not necessarily associated with geologic repositories and are concentrations of selected radionuclides in water, each of which would result in a dose of not more than $500 \mathrm{mrem} / \mathrm{yr}$ to an individual who consumed water with these concentrations at a rate of 2.2 L/day. The RCG values are used as an additional basis of comparison in this study because the majority of releases to ground water that are estimated to result from a faulting event would not be expected to inigrate the $10 \mathrm{~km}$ distance required to reach the accessible environinent as defined by EPA. As a result, comparison of isotopes in leached waste within the confines of a repository to cumulative releases reaching a $10-\mathrm{km}$ boundary is not believed to provide useful perspective. The RCG values for the selected isotopes used in this study are presented in Table 6.8 .

\subsubsection{Natural Event Releases}

In Section 6.3.1, a geologic fault permitting ground water to enter and exit a repository is suggested to be the most likely hypothetical natural disruptive event for release of radionuclides. Without the mechanism for flow 
TABLE 6.8. Radionuclide Concentration Guide (RCG) Values

for Selected Radionuclides in Water (NRC 1981a)

\begin{tabular}{|c|c|}
\hline Radionuclide & $\mathrm{RCG}(\mathrm{a})(\mathrm{uCi} / \mathrm{mL})$ \\
\hline $241_{A m}$ & $4 \times 10^{-6}$ \\
\hline $243_{\mathrm{Am}}$ & $4 \times 10^{-6}$ \\
\hline${ }^{14} \mathrm{C}$ & $8 \times 10^{-4}$ \\
\hline${ }^{135} \mathrm{Cs}$ & $1 \times 10^{-4}$ \\
\hline${ }^{137} \mathrm{Cs}$ & $2 \times 10^{-5}$ \\
\hline${ }^{237} \mathrm{~Np}$ & $3 \times 10^{-6}$ \\
\hline $238 \mathrm{Pu}$ & $5 \times 10^{-6}$ \\
\hline${ }^{239} \mathrm{Pu}$ & $5 \times 10^{-6}$ \\
\hline $240 \mathrm{Pu}$ & $5 \times 10^{-6}$ \\
\hline $242 \mathrm{pu}$ & $5 \times 10^{-6}$ \\
\hline${ }^{226} \mathrm{Ra}$ & $3 \times 10^{-8}$ \\
\hline${ }^{90} \mathrm{Sr}$ & $3 \times 10^{-7}$ \\
\hline${ }^{126} \mathrm{Sn}$ & Not determined \\
\hline${ }^{99} \mathrm{TC}$ & $3 \times 10^{-4}$ \\
\hline $129_{I}$ & $6 \times 10^{-8}$ \\
\hline
\end{tabular}

(a) Values are concentrations of radionuclides in water, each of which would result in a dose of not more than $500 \mathrm{mrem} / \mathrm{yr}$ to an individual who consumed water with these concentrations at a rate of $2.2 \mathrm{~L} /$ day.

of water created by a fault, water would be unlikely to leach significant quantities of the waste.(a) The impacts of a fault scenario followed by intrusion of ground water have been addressed by Dove et al. (1982), and that analysis is the basis for the release mechanism assumed in the present study. However, modifications are made to account for the fact that a spent-fuel

(a) If water did contact waste as a result of gradual movement of a saturated front, it would be moving at an almost imperceptible rate and, therefore, not pose a threat by releasing radionuclides to the accessible environment within 1,000 years. 
inventory was used in Dove et al. (1982), whereas the present study assumes reprocessed $\mathrm{HLW}$ from U/PU recycle.

The measures of impact used to present the results of a faulting event are: cumulative releases of isotopes to ground water in the fault zone, and radionuclide concentrations in the ground water within the fault zone.

The hypothetical faulting event used in this analysis is assumed to occur at either 100 or 1,000 years after repository closure. The faulting event is of sufficient magnitude such that the fault plane extends beyond the repository boundary. The fault intersects the repository and allows hydraulic connection of the upper and lower aquifers. Shear at the fault plane is assumed to cut the waste canisters in two. Each remnant is open on one end over which water flows. The waste form is assumed to be predominately $\mathrm{SiO}_{2}$ and radionuclides are released as the $\mathrm{SiO}_{2}$ matrix dissolves. As a result, each radionuclide is released to ground water in proportion to its concentration in the waste glass.

In a generic sense, the nuclides released to ground water can be described as the product of the following terms:

$$
\begin{aligned}
\text { Nuclide release }= & (\text { Rate of faulting }) \times\left(\frac{\text { Canisters exposed }}{\text { event }}\right) \\
& \times\left(\frac{\mathrm{kg} \text { waste }}{\text { canister }}\right) \times\left(\frac{\text { Isotopic inventory }}{\mathrm{kg} \text { of waste }}\right)
\end{aligned}
$$

After development of the several terms, some manipulation, and simplification, this expression is transformed to: (a)

Nuclide release $=\frac{(f) \times\left(A_{R}\right)^{1 / 2} \times\left(T_{R}\right) \times\left(I_{R}\right) \times\left(L_{R}\right) \times(2) \times(T) \times(10)\left(e^{-\lambda T} 1-e^{-\lambda T_{2}}\right)}{(H) \times(D) \times(\sin \theta) \lambda}$

(a) Details of The development of this expression are presented in Appendix D.

(b) It is recognized that for radionuclides that exhibit in-growth of daughter products, a more complicated decay chain exists. Such decay chains were used when estimating releases to ground water from these several radionuclides. 
where:

$f=$ frequency in units of events per unit time per unit area

$A_{R}=$ repository area in $\mathrm{km}^{2}$

$T_{R}=$ repository thickness in $\mathrm{cm}$

$I_{R}=$ repository inventory in MTE

$L_{R}=$ leach rate in $\mathrm{g} / \mathrm{cm}^{2}$-day

$T=$ period of time over which leaching occurs

Io = initial isotopic inventory in $\mathrm{Ci} / \mathrm{MTE}$

$H=$ canister height in $\mathrm{cm}$

$D=$ glass density in $\mathrm{kg} / \mathrm{cm}^{3}$

$\theta=$ fault angle

$\lambda=\ln 2$ divided by half-life of isotope

$T_{1}=$ year when fault occurs

$T_{2}=$ year when calculation is terminated.

Several of the parameters in Equations 6.2 and 6.4 are defined as constants in this study. These include faulting frequency ( $f$ ), repository thickness $\left(T_{R}\right)$, repository inventory $\left(I_{R}\right)$, leach rate $\left(L_{R}\right)$, period of time over which leaching occurs $(T)$, canister height $(H)$, glass density (D), fault angle $(\theta)$, the year when the fault occurs $\left(T_{1}\right)$, the year when the calculation is terminated $\left(T_{2}\right)$, and flow rate $\left(F_{R}\right)$. Values assumed for the remainder of the parameters in Equations 6.2 and 6.4 (with the exception of Io) are presented in Tables 6.9, 6.10, and 6.11 for the Reference Case, Alternative A, and Alternative $B$, respectively.

Similarly, the concentration of the nuclides in ground water can be described as the product of:(a)

$$
\begin{aligned}
\text { Concentration }= & \left(\frac{\mathrm{kg} \text { waste leached }}{\text { canister-time }}\right) \times\left(\frac{\text { Isotopic inventory }}{\mathrm{kg} \text { of waste }}\right) \\
& \times\left(\frac{\text { Flow rate }}{\text { canister }}\right)^{-1}
\end{aligned}
$$

(a) Details of the development of this equation are presented in Appendix D. 
TABLE 6.9. Input Parameters to Faulting Event Calculation-Reference Case

\begin{tabular}{|c|c|c|c|c|c|}
\hline Subcase (a) & $\frac{\text { MTE }}{\text { Canister }}$ & $\frac{\mathrm{kg} \mathrm{glass}}{\mathrm{MTE}}$ & $\begin{array}{l}\text { Canister } \\
\text { Radius }(\mathrm{cm}) \\
\end{array}$ & $\begin{array}{l}\text { Repository (b) } \\
\text { Area }\left(\mathrm{km}^{2}\right)\end{array}$ & $\begin{array}{l}\text { Canister } \\
\text { Spacing (m) }\end{array}$ \\
\hline$a$ & 0.167 & 833 & 7.6 & 29.5 & 3.5 \\
\hline b & 0.389 & 358 & 7.6 & 17.3 & 4.0 \\
\hline c & 0.639 & 218 & 7.6 & 11.3 & 4.2 \\
\hline d & 0.907 & 153 & 7.6 & 8.4 & 4.5 \\
\hline
\end{tabular}

(a) Based on maximum bentonite temperatures of $100^{\circ} \mathrm{C}, 150^{\circ} \mathrm{C}, 200^{\circ} \mathrm{C}$, and $250^{\circ} \mathrm{C}$ for subcases $a, b, c$, and $d$, respectively.

(b) Emplacement areas only.

TABLE 6.10. Input Parameters to Faulting Event Calculation--Alternative A

\section{Waste} Inventory

FHLW se (a) $\frac{\text { MTE }}{\text { Canister }}$

$\begin{array}{ll}\mathrm{a} & 0.627 \\ \mathrm{~b} & 1.45 \\ \mathrm{c} & 2.48 \\ \mathrm{~d} & 3.63\end{array}$

$\mathrm{Cs} / \mathrm{Sr}$

2.64

Subcase ${ }^{(a)} \quad \frac{M T E}{\text { Canister }}$
$\mathrm{kg}$ glass MTE Canister
Radius $(\mathrm{cm})$ Repository (b) b) Canister 222 95.8

7.6

9.9

5.3

117

7.6

117
3.4

1.1

1.3

2.1

1.4

3.0 Spacing (m)

(a) Subcase a for alternative defined as row 1 from FHLW plus Cs/Sr row. Subcase $b$ for alternative defined as row 2 from FHLW plus Cs/Sr row. Subcase $c$ for alternative defined as row 3 from FHLW plus Cs/Sr row. Subcase $d$ for alternative defined as row 4 from FHLW plus Cs/Sr row.

(b) Emplacement areas only.

TABLE 6.11. Input Parameters to Faulting Event Calculation--Alternative $B$

\begin{tabular}{|c|c|c|c|c|c|}
\hline Subcase & $\frac{\text { MTE }}{\text { Canister }}$ & $\frac{\mathrm{kg} \text { glass }}{\mathrm{MTE}}$ & $\begin{array}{c}\text { Canister } \\
\text { Radius (cm) } \\
\end{array}$ & $\begin{array}{l}\text { Repository } \\
\text { Area }\left(\mathrm{km}^{2}\right)\end{array}$ & $\begin{array}{l}\text { Canister } \\
\text { Spacing }(\mathrm{m})\end{array}$ \\
\hline a & 0.627 & 222 & 7.6 & 9.9 & 3.8 \\
\hline b & 1.45 & 95.8 & 7.6 & 5.3 & 4.6 \\
\hline$c$ & 2.48 & 119 & 1.1 & 3.4 & 5.0 \\
\hline d & 3.63 & 112 & 1.3 & 2.1 & 4.5 \\
\hline
\end{tabular}


After development of these terms, some manipulation, and simplification, the expression is transformed to:

$$
\text { Concentration }=\frac{\left(L_{R}\right) \times(2) \times(\pi)^{4} \times(R c)^{2} \times(\text { Io }) \times\left(e^{-\lambda T} 1\right)}{(G) \times\left(F_{R}\right) \times(\cos \theta)}
$$

where:

$$
\begin{aligned}
\mathrm{L}_{\mathrm{R}} & =\text { leach rate in } \mathrm{g} / \mathrm{cm}^{2} \text {-day } \\
\mathrm{R}_{C} & =\text { canister radius in } \mathrm{cm} \\
\mathrm{IO}_{0} & =\text { initial isotopic inventory in Ci/MTE } \\
\lambda & =\text { ln } 2 \text { divided by half-life of isotope } \\
\mathrm{T}_{1} & =\text { year when fault occurs } \\
\mathrm{G} & =\text { glass loading in } \mathrm{kg} \mathrm{glass} / \mathrm{MTE} \\
\mathrm{F}_{\mathrm{R}} & =\text { flow rate in } \mathrm{mL} / \text { day } \\
\theta & =\text { fault angle with respect to the horizontal plane. }
\end{aligned}
$$

The values for initial isotopic inventory (IO) were taken from DOE (1979a), Tables 3.3.9 and 3.3.14. The values for the isotopes (whose cumulative releases were estimated) are similar for both the Reference Case and Alternative B. However, because Alternative A requires an additional processing step, there are separations factors that must be applied to the data in DOE (1979a) in order to determine what fraction of a particular isotope is in FHLW and in the Cs/Sr component. The necessary separations factors are detailed in Chapter 4.

Inserting the data in Tables 6.9 through 6.11 and in Tables 3.3.9 and 3.3.14 (DOE 1979a) into Equations 6.2 and 6.4 yields cumulative releases to and concentrations in ground water. For discussion purposes only, cumulative

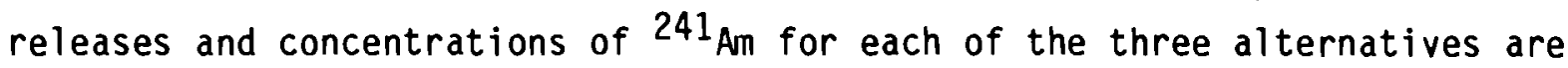
presented here. Detail on releases and concentration of other isotopes examined is provided in Section D. 3 of Appendix D.

Releases of ${ }^{241} \mathrm{Am}$ to the ground water within the fault zone are given in Table 6.12. In order to make a comparison of these releases to the EPA release limits, some estimation of the transport time of each radionuclide must be made. The transport time of each radionuclide away from the repository is a 
TABLE 6.12. Cumulative Releases and Maximum Concentrations of ${ }^{241}$ Am for Each Alternative and Subcase

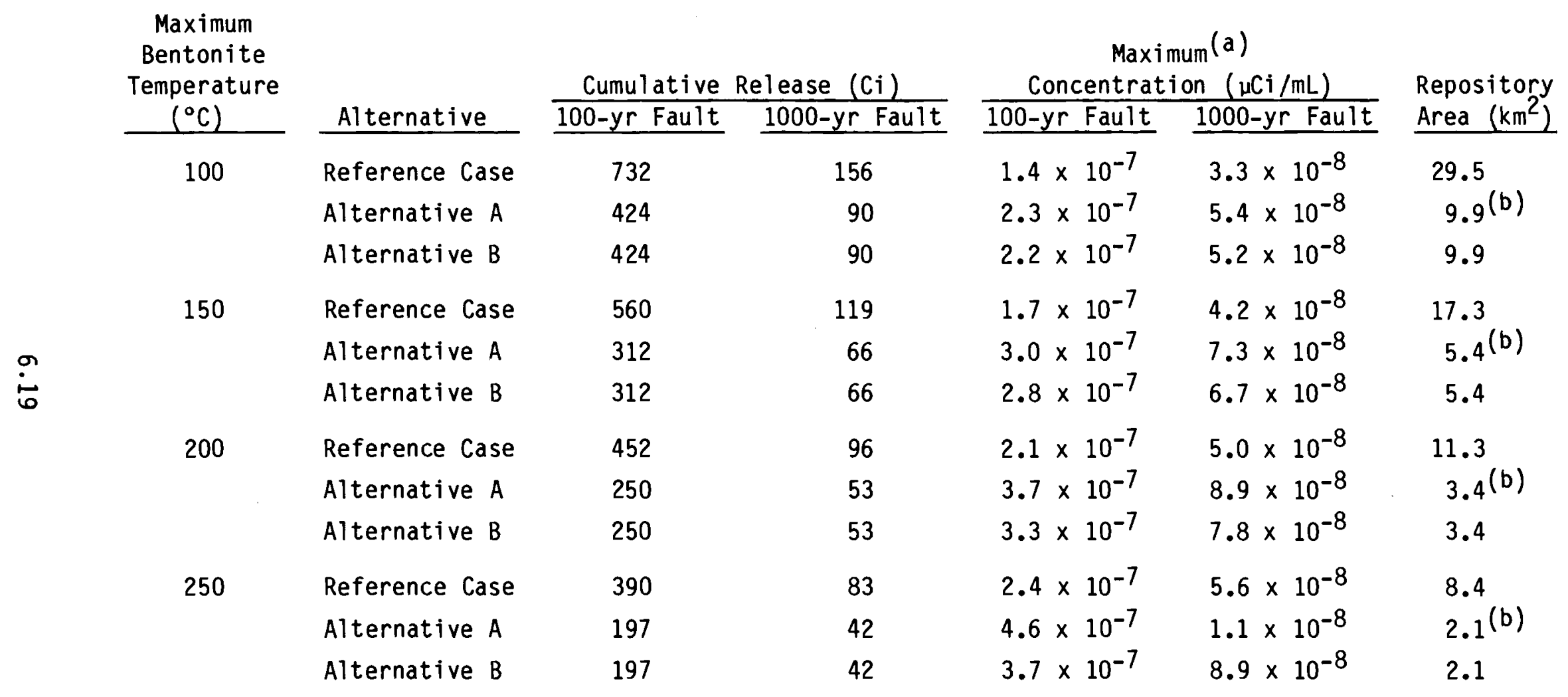

(a) The RCG value for $241_{\text {Am is }} 4.0 \times 10^{-6} \mu \mathrm{Ci} / \mathrm{mL}$.

(b) Area is for FHLW region of repository only, which is where the majority of the $241_{\text {Am }}$ is present. 
function of ground-water velocity and the $K d$ of each element. The $K d$ is a measure of the ability of a geologic medium to retard a given nuclide, expressed as $\mathrm{mL} / \mathrm{g}$. Estimated transport times and distances for elements released in the basalt repository used for this study are contained in Table 6.13. At the velocities shown, no elements would reach the accessible environment (defined by EPA as $10 \mathrm{~km}$ from the repository boundary) and, therefore, EPA limits would

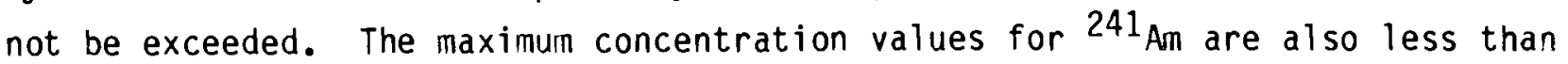
the RCG value, at least a factor of 9 smaller in all cases.

In addition, for the range of canister radius, repository area, canister loading, and canister spacing values assumed, no significant differences in either cumulative releases ( $i . e .$, less than a factor of $\sim 3.5$ ) or maximum concentrations (i.e., less than a factor of $\sim 3.5$ ) across the three alternatives are observed. This would indicate that there is no real incentive to either fractionate or age HLW from the standpoint of mitigating the impacts associated with a faulting type of event.

TABLE 6.13. Estimated Transport Times for Radionuclides in a Basalt Repository (Dove et al. 1982)

\begin{tabular}{|c|c|c|c|c|c|}
\hline \multirow[b]{2}{*}{ Element } & \multirow[b]{2}{*}{$\mathrm{Kd}$} & \multirow{2}{*}{$\begin{array}{l}\text { Retardation } \\
\text { Factor } \\
\end{array}$} & \multicolumn{3}{|c|}{ Estimated Migration Distance $(\mathrm{km})(\mathrm{a})$} \\
\hline & & & $1,000 \mathrm{Yr}$ & $10,000 \mathrm{Yr}$ & $1.0 \times 10^{5} \mathrm{Yr}$ \\
\hline Am & 50 & 580 & $3.8 \times 10^{-4}$ & $3.8 \times 10^{-3}$ & 0.038 \\
\hline C & 0 & 1 & 22 & 22 & 22 \\
\hline Cs & 300 & 3,500 & $6.4 \times 10^{-5}$ & $6.4 \times 10^{-4}$ & $6.4 \times 10^{-3}$ \\
\hline I & 0 & 1 & 22 & 22 & 22 \\
\hline $\mathrm{Np}$ & 150 & 1,700 & $1.3 \times 10^{-4}$ & $1.3 \times 10^{-3}$ & 0.013 \\
\hline $\mathrm{Pu}$ & 500 & 5,800 & $3.6 \times 10^{-5}$ & $3.6 \times 10^{-4}$ & $3.6 \times 10^{-3}$ \\
\hline $\mathrm{Ra}$ & 50 & 580 & $3.8 \times 10^{-4}$ & $3.8 \times 10^{-3}$ & 0.03 \\
\hline Sn & 50 & 580 & $3.8 \times 10^{-4}$ & $3.8 \times 10^{-3}$ & 0.03 \\
\hline $\mathrm{Sr}$ & 100 & 120 & $1.9 \times 10^{-4}$ & $1.9 \times 10^{-3}$ & 0.01 \\
\hline Tc & 20 & 230 & $9.4 \times 10^{-4}$ & $9.4 \times 10^{-3}$ & 0.09 \\
\hline
\end{tabular}

(a) Migration distance based on a water velocity of $0.22 \mathrm{~m} / \mathrm{yr}$. 
It was further determined that varying canister radius and canister loading have no influence on curie releases to ground water, while varying repository area does influence release. Canister spacing will influence release only to the degree that this parameter affects repository area.

Varying canister radius (assuming a constant repository area) will be accompanied by either a change in waste loading or number of canisters. If either of these parameters change, then the waste per canister will vary as a fraction of the change in the square of the canister radius. The available leaching area will also change as a function of the square of the canister radius, but in a compensating manner.

Varying canister loading does not influence releases to ground water (again, assuming a constant repository area) because while varying this parameter will tend to vary the number of canisters (and, thereby, canisters exposed per event), any change will be counter-balanced by an offsetting change in waste inventory per canister.

Repository area influences cumulative release essentially because the fault plane is assumed to extend beyond the repository horizon. As a result of this assumption, the zone of intersection becomes a function of repository area (i.e., $\left(A_{R}\right) \times\left(T_{R}\right) \times(\cos \theta)$, as shown in Figure 6.1). If the zone of intersection were not defined as a function of repository area, increasing repository area would tend to increase the theoretical frequency of faulting but would tend to decrease the number of canisters contacted for a given fault.

This relationship between the exposed portion of the repository and repository area accounts for the variation in releases to ground water across the alternatives shown in Table 6.12; that is, the ratio for the cumulative release for one subcase versus another is approximately equal to the ratio of the square root of the repository areas for the respective subcases. The smaller repository areas associated with Alternatives $A$ and $B$ are due to the more efficient emplacement of canisters resulting from fractionation and aging of waste.

In conclusion, there appears to be no incentive to either fractionate or age HLW from the standpoint of mitigating the impacts associated with a faulting type of event. In addition, varying canister loading and canister radi $i$ has no influence on cumulative releases (assuming constant repository area). 


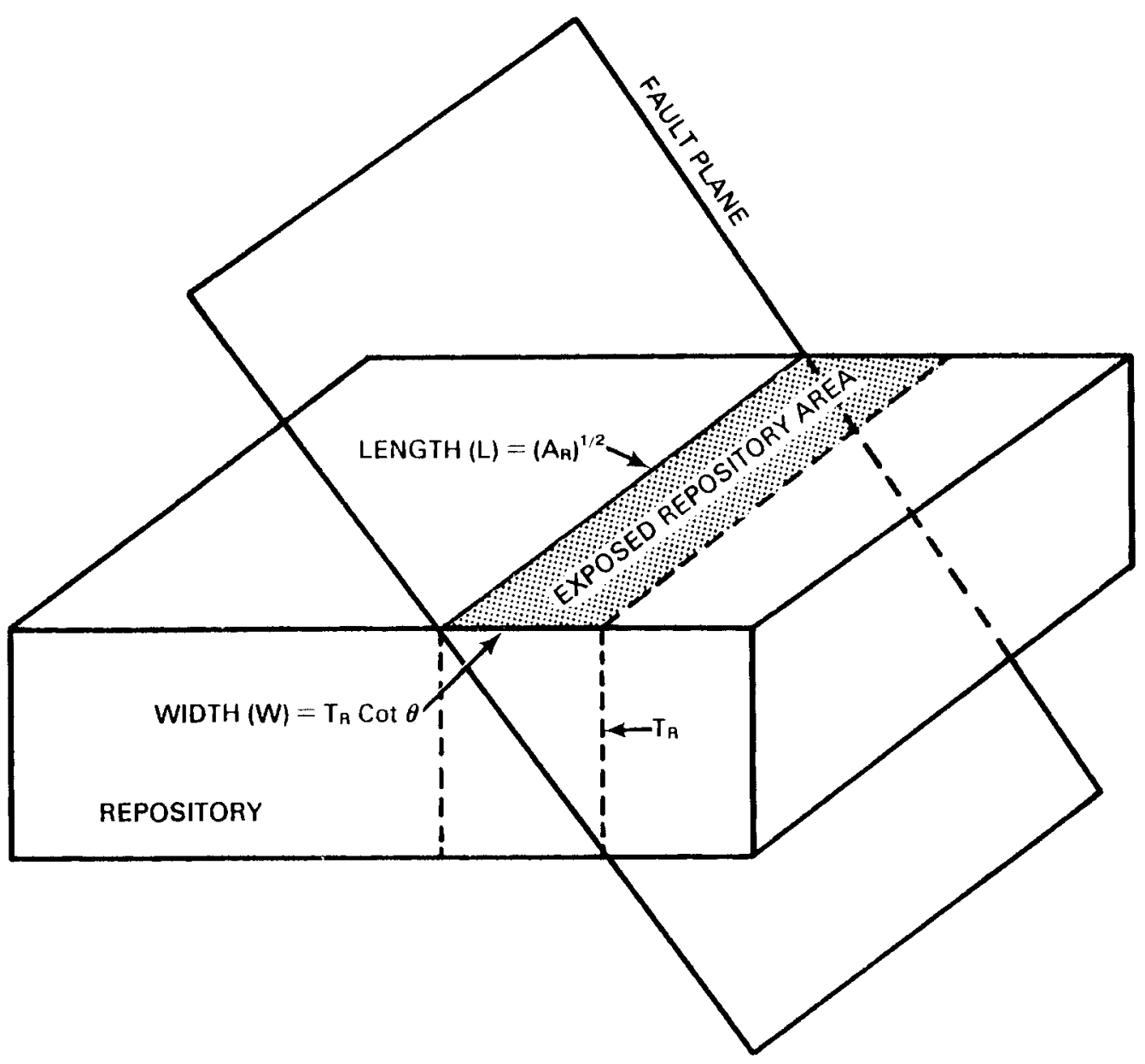

FIGURE 6.1. Schematic of Exposed Repository Area

However, canister spacing will influence cumulative release but only to the extent that canister spacing affects repository area (i.e., if spacing is not compensated for by canister loading). These conclusions are generally the same for the other isotopes examined and presented in Section D.3 of Appendix D.

\subsubsection{Human Intrusion}

Human intrusion into a geologic repository is estimated to result from two kinds of actions: deliberate and inadvertent.

Deliberate intrusion by a future population is defined as intentional entrance into a repository for a repository-related purpose. The intrusion implies that the individual or group is aware of the content either through functioning institutional controls, or through a technological awareness and 
capability existing in that society. In either case, prior knowledge allows these individuals to evaluate and assume the risks associated with exhuming the contents of the repository.

Inadvertent intrusion results from activities undertaken without prior knowledge of the contents or characteristics of the repository. This kind of intrusion implies that either institutional controls have ceased to function, or that the technological capabilities of this future society are not sophisticated enough to detect the presence of radioactivity. In either case, this group is unable to fully assess the risk of their actions. As a result, it is believed that the present society should consider inadvertent human intrusion as part of the overall evaluation of repository effectiveness (Hebert et al. 1978). In this study, the only inadvertent human intrusion events examined are exploratory drilling for resources or for geologic study.

The NRC, in its Proposed Rule on Disposal of High-Level Radioactive Wastes in Geologic Repositories (1981b), makes several statements regarding human intrusion. First, because of the historical example of successful information transfer, a requirement to adequately mark a site, and the technology that is available to drill to repository depths, inadvertent intrusion is "highly improbable" for at least "several hundred years." Second, intrusion for the purpose of sabotage is not expected to occur covertly. Third, NRC's proposed technical criteria are structured to avoid sites with any resource value or sites that might attract future societies. Fourth, following site selection, the NRC believes it is of little value to argue whether siting provisions are adequate for the future, to speculate on potential human intrusion disruptive events, or to postulate whether such scenarios violate EPA limits. In spite of this, an analysis of a human intrusion event, direct drilling into a geologic repository, was included below because such an analysis might provide a basis for discriminating between alternatives in the context of this study.

Direct drilling into a geologic repository (assuming an inadvertent action) could result either from resource exploration or from geologic study. For purposes of this study, it was assumed that following repository closure an individual (or individuals) could sink a drill bit over the repository without prior knowledge of its existence. It was further assumed that such an event 
could occur more than once, given sufficient time. Each time that an individual(s) would drill, there is some likelihood that a canister would be contacted by the drill bit. Given the possible orientations of the contact, there would be some fraction of the canister on average that would be removed to the surface. Finally, the curies brought to the surface would be a function of when the event(s) occur(s) and the decay characteristics of the radionuclides within the waste.

In a generic sense, then, the expected impact(a) from direct drilling can be considered the product of the following terms:

Expected impact $=$ (Rate of drilling)

$x$ (Likelihood of contacting canister if drilling occurs)

$x$ (Fraction of canister removed to surface if contacted)

$x$ (Canister inventory)

After development of the several terms, some manipulation, and simplification, this expression is transformed to: (b)

$$
\begin{aligned}
\text { Expected impact }= & \frac{(f) \times\left(I_{R}\right) \times(G)}{(H) \times(D)} \times\left[\left(\frac{R d}{R C}\right)^{2}+\frac{1}{3}\left(\frac{R d}{R C}\right)^{4}\right] \\
& \times(W) \times(\text { Io }) \times\left(\frac{e^{-\lambda T} 1-e^{-\lambda T} 2}{\lambda}\right) \text { (C) }
\end{aligned}
$$

where:

$f=$ frequency in limits of events per unit time per unit area $I_{R}=$ repository inventory in MTE

(a) Expected impact is used here in the same manner the term "expected value" is used in statistics. Expected impact is the mathematical product of the likelihood of an event occurring multiplied by the consequences of its occurrences.

(b) Details of the development of this equation are presented in Appendix $D$.

(c) It is recognized that for radionuclides that exhibit in-growth of daughter products, a more complicated decay chain exists. Such decay chains were used when estimating releases to ground water from these several radionuclides. 


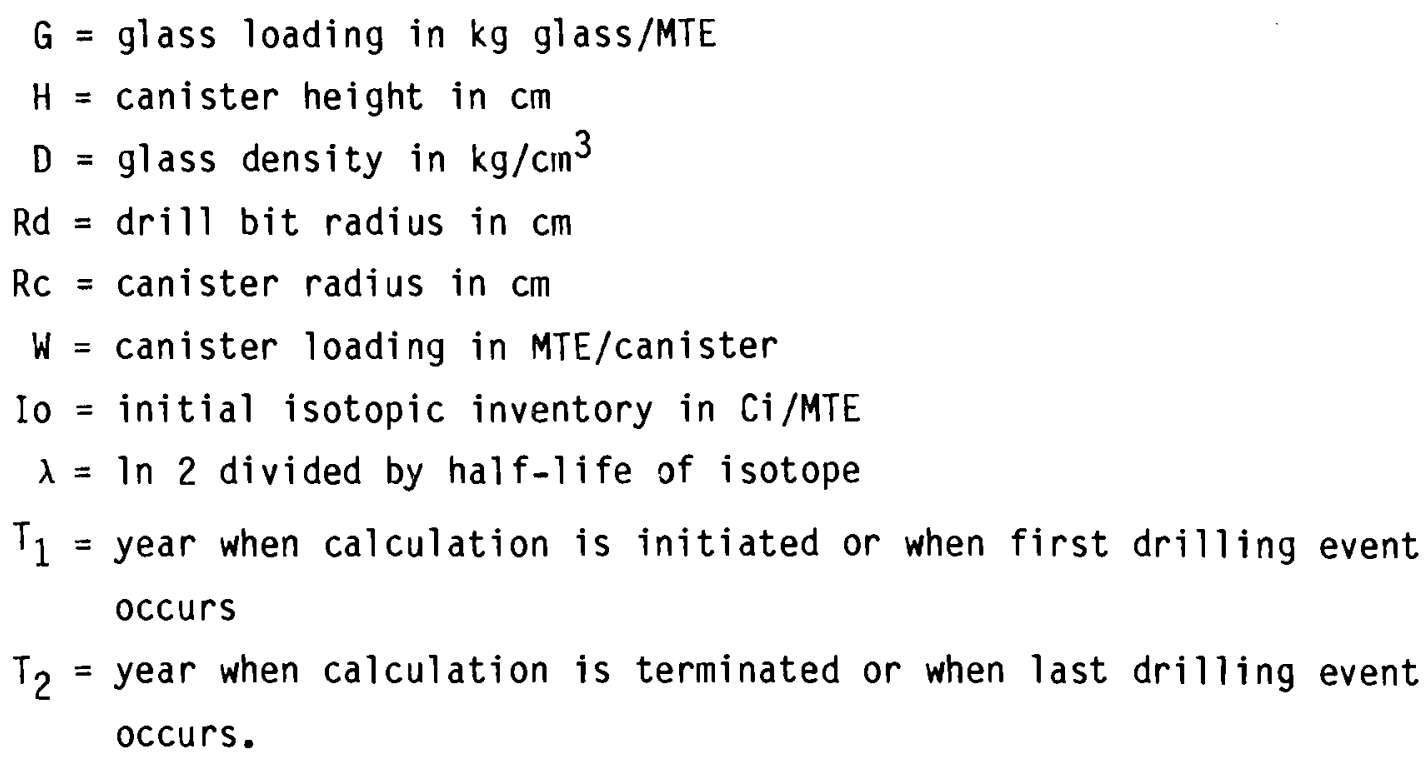

The units of Equation 6.6 are cumulative curies removed to the surface over some time period. By assuming this time period is 10,000 years after repository closure, the results obtained from using this equation can be compared to EPA (1982) release limits to provide additional perspective.

Not all of the parameters in Equation 6.6 are defined as variables in this study. Drilling frequency $(f)$, repository inventory $\left(I_{R}\right)$, canister height $(H)$, glass density (D), drill radius ( $R d)$, initiation time of calculation $\left(T_{1}\right)$, and time when calculation is terminated $\left(T_{2}\right)$ are assumed to be constants.

The values for the initial isotopic inventory (I0) were taken from DOE (1979a), Tables 3.3.9 and 3.3.14. The values for the isotopes (whose cumulative releases were estimated) are similar for both the Reference Case and Alternative $B$. However, because Alternative $A$ requires an additional processing step, there are separations factors that must be applied to the data in DOE (1979a) in order to determine what fraction of a particular isotope is in FHLW and in the CS/Sr component. The necessary separations factors are detailed in Chapter 4.

Inserting the data in Tables 6.9 through 6.11 and in Tables 3.3 .9 and 3.3.14 (DOE 1979a) into Equation 6.6 yielded cumulative releases of isotopes from drilling events occurring over 10,000 years. For discussion purposes, only cumulative releases of $241 \mathrm{Am}$ for each of the three alternatives are presented here. Detail on cumulative releases of the other isotopes examined is provided in Appendix $D$. 
As shown in Table 6.14, releases for ${ }^{241} \mathrm{Am}$ are far below the $\left({ }^{241} \mathrm{Am}\right)$ cumulative release limit as defined by EPA. In addition, for the range of canister radius, repository area, canister loading, and canister spacing values assumed, no significant differences in cumulative releases across the three alternatives are observed. This indicates that there is no real incentive to either fractionate or age HLW waste from the standpoint of mitigating the impacts associated with a drilling-type human intrusion event.

It was further determined that varying repository area, canister loading, and canister spacing values has no influence on cumulative release, while varying canister radius does, to some degree, influence curies released to the surface. Increasing (or decreasing) repository area tends to increase (or decrease) the number of drilling events that could occur within the repository boundary. This change in number of events will be compensated for by a change in the likelihood of contacting or intersecting a canister, should drilling occur.

Increasing (or decreasing) canister loading tends to increase (or decrease) the release from each drill-canister intersection. However, it decreases or increases by a proportional amount the number of canisters and, hence, the likelihood of contacting a canister. Increasing or decreasing canister spacing does not influence cumulative release because physically changing the location of (or rearranging) a set of canisters does not alter the likelihood of contacting any one canister given a random drilling event.

Varying canister radius does influence cumulative release through the

$$
\left(\frac{R d}{R C}\right)^{2}+\frac{1}{3}\left(\frac{R d}{R C}\right)^{4} \text { term, which is present in Equation } 6.6
$$

As canister radius increases (drill bit size remaining constant), the above term would tend to decrease and become asymptotic. While increasing canister radius would tend to slightly increase the likelihood of the contact term $\left(\right.$ e.g., $\left.(R+R)^{2}>(R)^{2}\right)$, this increase would diminish at larger radi $i$ and would be more than compensated for by a decrease in the weighted fraction removed term. Specifically, when drill bit size exceeds canister size, a direct hit is not required to bring up the maximum fraction (i.e., 100\%) from the canister. When drill bit and canister size are equal, only for a hit where the centers 
TABLE 6.14. Cumulative Release of $241_{\text {Am }}$ for Each Alternative and Subcase

\begin{tabular}{|c|c|c|c|c|}
\hline $\begin{array}{l}\text { Maximum Bentonite } \\
\text { Temperature }\left({ }^{\circ} \mathrm{C}\right)\end{array}$ & Alternative & $\begin{array}{l}\text { Cumulative } \\
\text { Release (Ci) } \\
\end{array}$ & $\begin{array}{l}\text { Canister } \\
\text { Radius }(\mathrm{cm}) \\
\end{array}$ & $E P A(a)$ \\
\hline \multirow[t]{3}{*}{100} & Reference Case & 13 & 7.6 & 514 \\
\hline & Alternative $A$ & 13 & $7.6(b)$ & 514 \\
\hline & Alternative $B$ & 13 & 7.6 & 514 \\
\hline \multirow[t]{3}{*}{150} & Reference Case & 13 & 7.6 & 514 \\
\hline & Alternative $\mathrm{A}$ & 13 & $7.6(b)$ & 514 \\
\hline & Alternative $B$ & 13 & 7.6 & 514 \\
\hline \multirow[t]{3}{*}{200} & Reference Case & 13 & 7.6 & 514 \\
\hline & Alternative $A$ & 11 & $11(b)$ & 514 \\
\hline & Alternative $B$ & 11 & 11 & 514 \\
\hline \multirow[t]{3}{*}{250} & Reference Case & 13 & 7.6 & 514 \\
\hline & Alternative $A$ & 10 & $13^{(b)}$ & 514 \\
\hline & Alternative $B$ & 10 & 13 & 514 \\
\hline
\end{tabular}

(a) Based on information in EPA (1982) and assuming the 50,000 MTE repository contains $8.7 \times 10^{5} \mathrm{Ci}$ of alpha-emitting transuranic (TRU) wast

(b) Canister radius of FHLW canisters, which is where majority of ${ }^{241} \mathrm{Am}$ inventory is present.

are concentric would the maximum fraction be brought to the surface. When canister size exceeds drill bit size, the maximum fraction brought to the surface would be limited by drill size and would be a successively smaller fraction of the canister contents as canister size increases. For canister radii much greater than drill bit radii, essentially no change in cumulative release would be observed when canister radius is varied.

In conclusion, there appears to be no incentive to either fractionate or age HLW from the standpoint of mitigating the impacts associated with a drilling type of event. In addition, varying repository area, canister loading, and canister spacing has no influence on cumulative releases. However, varying canister radius will influence cumulative releases but only for canister radi $i$ smaller than drill bit size. These conclusions are generally the same for the other isotopes examined and presented in Section D.3 of Appendix D. 



\subsection{REFERENCES}

Altenhofen, M. K. 1981. Waste Package Heat Transfer Analysis: Model Development and Temperature Estimates for Waste Packages in a Repository Located in Basalt. RHO-BWI-ST-18, Rockwell Hanford Operations, Richland, Washington.

Bechtel National, Inc. 1979. National Waste Terminal Storage - Conceptual Reference Repository Description. ONWI/SUB/79/E512-01600.16. Prepared for the Office of Nuclear Waste IsoTation by Battelle-Columbus Laboratories, Columbus, Ohio.

Brown, R. W. 1980. Standardized Repository and Encapsulation Facility Cost Estimates for Comparative Evaluation and Pricing Study. ONWI-110. Prepared for the Office of Nuclear Waste Isolation by Battelle-col umbus Laboratories, Columbus, Ohio.

Clark, L. L., et a1. 1983. RECON: A Computer Program for Analyzing Repository Economics. PNL-4465, Pacific Northwest Laboratory, Richl and, Washington.

Crane, R. A., and R. I. Vachon. 1977. "A Prediction of the Bounds on the Effective Thermal Conductivity of Granular Materials." Int. J. of Heat and Mass Transfer. 20:711-723.

Daling, P. M. 1983. Analys is of Near-Term Spent Fuel Transportation Hardware Requirements and Transportation Costs. PNL-4575, Pacific Northwest Laboratory, Richland, Washington.

Dove, F. H., et al. 1982. AEGIS Technology Demonstration for a Nuclear Waste Repository in Basalt. PNL-3632, Pacific Northwest Laboratory, Richland, Washington.

Eckert, E. R. G., and R. M. Drake, Jr. 1972. Analysis of Heat and Mass Transfer. pp. 535-541. McGraw-Hi11, New York.

Exxon Nuclear Company, Inc. 1978. Final Report for Study of the Separation and Recovery of Select Radioisotopes from Commercial Nuclear Fuel Wastes. Richland, Washington.

Hebert, J. A., et al. 1978. Non-Technical Issues in Waste Management: Ethical, Institutional, and Political Concerns. PNL-2400, Battelle Human Affairs Research Centers, Seattle, Washington.

Hi11, 0. F., et al. 1981. Preconceptual Design Study for Solidifying HighLevel Waste: Appendices A, B, C, West Valley Demonstration Project. DOE/TIC-11433, PNL-3608-2, Pacific Northwest Laboratory, Richland, Washington. 
Kuehn, T. H., and R. J. Goldstein. 1973. "An Experimental Study of Natural Convection Heat Transfer in Concentric and Eccentric Horizontal Cylinderical Annul i." J. Heat Transfer. 100:635-640.

Kuehn, T. H., and R. J. Goldstein. 1976a. "An Experimental and Theoretical Study of Natural Convection in the Annulus Between Horizontal Concentric Cylinders." J. Fluid Mechanics. 74:695-719.

Kuehn, T. H., and R. J. Goldstein. 1976b. "Correlating Equations for Natural Convection Heat Transfer Between Horizontal Circular Cylinders." Int. J. Heat Mass Transfer. 19:1127-1134.

Kwon, S. S., T. H. Kuehn and T. S. Lee. 1982. "Natural Convection in the Annular Between Horizontal Circular Cylinders With Three Arial Spacers." Trans. ASME. 104:118-124.

McCallum, R. F., et al. 1982. Waste Mixes Study for Space Disposal. ONWI422, Office of Nuclear Waste Isolation, Columbus, Ohio.

McCann, R. A. 1980. HYDRA-I: A Three-Dimensional Finite Difference Code for Calculating the Thermal Hydraulic Performance of a Fuel Assembly Contained Within a Canister. PNL-3367, Pacific Northwest Laboratory, Richland, Washington.

Mendel, J. E., et al. 1981. A State of the Art Review of Materials Properties of Nuclear Waste Forms. PNL-3802, Pacific Northwest Laboratory, Richtand, Washington.

Northrup, C. J., L. J. Jardine and M. J. Steindler. 1982. "An Alternate Strategy for Commercial High-Level Radioactive Waste Management." IAEA Symposium on the Conditioning of Radioactive Wastes for Storage and Disposal, Utrecht, the Netherlands, 21-25 June 1982.

Parsons, Brinkerhoff, Quade and Douglas (PBQ\&D). 1978. Technical Support for GEIS: Radioactive Waste Isolation in Geologic Formations. Y/OMI/TM-36, Vo1. 18. Prepared for and available from the U.S. Department of Energy, Washington, D.C.

Peterson, P. L., and R. E. Rhoads. 1978. Conceptual Design of a Shipping Container for Transporting High-Level Waste by Railroad. PNL-2244, Pacific Northwest Laboratory, Richland, Washington.

Platt, A. M., and E. A. Eschbach. 1981. "Rethinking the Management of HighLevel Nuclear Waste: The Need for Fractionation." Proceedings, Waste Management ' 81 , ANS Topical Meeting, Tuscon, Arizona.

Projahn, U., H. Reiger and H. Beer. 1981. "Numerical Analysis of Laminar Natural Convection Between Concentric and Eccentric Cylinders." Numerical Heat Transfer. 4:131-146. 
Scientific Applications, Inc. 1978. Technical Support for GEIS: Radioactive Waste Isolation in Geologic Formation. Vol. 19, Thermal Analysis, Y/OWI/TM36119. Oak Ridge, Tennessee.

Slate, S. C., W. A. Ross and W. L. Partain. 1981. Reference Commercial HighLevel Waste Glass and Canister Definition. PNL-3838, Pacific Northwest Laboratory, Richland, Washington.

Sweet, J. N., and J. E. McCreight. 1980. Thermal Conductivity of Rocksalt and Other Materials. SAND-79-1665, Sandia National Laboratory, Albuquerque, New Mexico.

Thadani, M. 1980. A Depth Optimization Study for Geologic Isolation of Radioactive Wastes. PNL-3079, Prepared by Teknekron, Inc., for Pacific Northwest Laboratory, Richland, Washington.

U.S. Department of Energy. 1979a. Technology for Commercial Radioactive Waste Management. DOE/ET-0028, Washington, D.C.

U.S. Department of Energy. 1979b. Environmental Aspects of Commercial Radioactive Waste Management. D0E/ET-0029, Washington, D.C.

U.S. Department of Energy. 1980. Final Environmental Impact Statement Management of Commercially Generated Radioactive Waste. DOE/EIS-0046F, Washington, D.C.

U.S. Department of Energy. 1981. The Monitored Retrievable Storage Concept. DOE/NE-0019, Washington, D.C.

U.S. Department of Energy. 1982. National Plan for Siting High-Level Radioactive Waste Repositories and Environmental Assessment. DOE/NWTS-4 and DOE/EA-151, PubTic Draft, Office of NWTS Integration, Battel le Memorial Institute, Columbus, Ohio.

U.S. Environmental Protection Agency. 1980. Technical Support of Standards for High-Level Radioactive Waste Management. EPA 520/4-79-007D, Washington, D.C.

U.S. Environmental Protection Agency. 1982. Environmental Standards and Federal Radiation Protection Guidance for Management and Disposal of Spent Nuclear Fuel, High-Level and Transuranic Radioactive Wastes. (Working Draft No. 21). Washington, D.C.

U.S. Nuclear Regulatory Commission. 1981a. Code of Federal Regulations. Title 10, Part 20, "Standards for Protection Against Radiation," Appendix, Table II, Washington, D.C.

U.S. Nuclear Regulatory Commission. 1981b. Code of Federal Regulations. Title 10, Part 60, "Disposal of High-Level Radioactive Wastes in Geologic Repositories," Washington, D.C. 
Wallace, R. W., et al. 1980. Topical Report on Release Scenario Analysis of Long-Term Management of High-Level Defense Waste at the Hanford Site. PNL3363, Pacific Northwest Laboratory, Richland, Washington.

Westinghouse Electric Corporation. 1981a. Engineered Waste Package Conceptual Design: Defense High-Level Waste (Form 1), Commercial High-Level Waste (Form 1), and Spent Fuel (Form 2) Disposal in Basalt. AESD-TME-3113, Westinghouse Electric Corporation, Pittsburgh, Pennsylvania.

Westinghouse Electric Corporation. 1981b. Engineered Waste Package Conceptual Design: Defense High-Level Waste (Form 1), Commercial High-Level Waste (Form 1), and Spent Fuel (Form 2) Disposal in Salt. AESD-TME-3131. Westinghouse Advanced Energy Systems Division, Pittsburgh, Pennsylvania. 


\section{DISTR IBUTION}

No. of

Copies

\section{OFFSITE}

27 DOE Technical Information Center

2 Division of Waste Management

U.S. Nuclear Regulatory

Commission

Washington, D.C. 20555

ATTN: J. B. Martin

$$
\text { R. F. Cook }
$$

3 Office of Waste Disposal and Remedial Action

U.S. Department of Energy Washingt on, D.C. 20545

ATTN: W. W. Ballard

F. E. Coffman

J.R. Col eman

4 Office of Defense Waste and Byproducts Management

U.S. Department of Energy

Washington, D.C. 20545

ATTN: J. J. Jicka

G. K. Oertel

W. C. Remini

G. H. Daly

2 Plans and Evaluations Division

Office of Nuclear Energy

U.S. Department of Energy

Washington, D.C. 20545

ATTN: J. P. Thereault

E. F. Mastal

K. 0. Laughon

Office of Spent Fuel Management and Reprocessing Systems

U.S. Department of Energy

Washington, D.C. 20545

Raymond Cooperstein

Office of Environmental

Protection, Safety and

Emergency Preparedness

U.S. Department of Energy

Washington, D.C. 20545
No. of

Copies

4 Nuclear Waste Policy Act Project office

U.S. Department of Energy

Washington, D.C. 20545

ATTN: C. R. Cooley

D. Z. Kaufman

J. W. Bennett

M. J. Lawrence

J. Neff

U.S. Department of Energy

Columbus Program office

505 King Avenue

Columbus, $\mathrm{OH} 43201$

3 Oak Ridge National Laboratory

P.0. Box Y

Oak Ridge, TN 37820

ATTN: K. Notz

T. Low

J. 0. Bl omeke

K. R. Braziel

Los Alamos Scientific Laboratory

P.0. Box 1663

Los Al amos, NM 87544

T. B. Hindman

DOE Savannah River Operations Of fice

P.0. Box A

Aiken, SC 29801

2 DOE Oak Ridge Operations Office

P.0. Box E

Oak Ridge, TN 37830

ATTN: S. Ahrends

D. E. Large 
No. of

Copies

3 DOE Albuquerque Operations Office

P.0. Box 5400

Albuquerque, NM 87185

ATTN: R. Y. Lowrey

D. T. Schueler

K. Carlson

J. B. Whitsett

DOE Idaho Operations office

550 2nd Street

Idaho Falls, ID 83401

S. A. Mann

DOE Chicago Operations office

Crystalline Rock Project office

9800 South Cass Avenue

Argonne, IL 60439

D. L. Veith

DOE Nevada Operations Office

Las Vegas, NV 89114

3 Allied-General Nuclear Services P.0. Box 847

Barnwell, SC 29812

ATTN: J. A. Buckham

W. L. Godfrey

A. K. Willi ams

2 Argonne National Laboratory

9700 South Cass Avenue

Argonne, IL 60439

ATTN: M. J. Steindler

L. E. Trevorrow

3 Battelle Memorial Institute

Office of Crystalline

Repository Development

505 King Avenue

Columbus, $\mathrm{OH} 43201$

ATTN: T. L. Anderson

M. Kehnemuyi

W. M. Pardue
No. of

Copies

6 Battelle Memorial Institute

Office of Nuclear Waste

Isolation

505 King Avenue

Columbus, $\mathrm{OH} 43201$

ATTN: S. H. Basham

W. Carbiener

J. 0. Duguid

S. Goldsmith

P. L. Ho fmann

Beverly Rawles

R. E. De Wames

Rockwell International

8900 DeSoto Avenue

Canoga Park, CA 91304

2 E. I. du Pont de Nemours Company Savannah River Laboratory

Aiken, SC 29801

ATTN: J. L. Crandall

E. J. Hennelly

R. Willi ams

Electric Power Research Institute $3412 \mathrm{Hillview} \mathrm{Avenue}$

P.0. Box 10412

Palo Alto, CA 94304

George Dix

266619 Haney Avenue

Damascus, MD 20750

R. K. Brown

Westinghouse Electric Corp. Advanced Energy Systems Div. WIPP Library

P.0. Box 40039

Albuquerque, NM 87196

2 Lawrence Livermore Laboratory

P. 0 . Box 808

Livermore, CA 94550

ATTN: J. H. Campbell

W. G. Sutcliff 
No. of

Copies

3 Sandia Laboratories

Albuquerque, NM 87185

ATTN: D. R. Anderson

C. J. Northrup

W. Weart

R. G Post

College of Engineering

University of Arizona

Tucson, AZ 85721

W. Tope

Westinghouse Electric Corp.

Mail Stop 23

Box 3912

Pittsburgh, PA 15230

Technological Assessment Division

Office of Radiation Programs

U.S. Environmental Protection Agency

Washington, D.C. 20460

2 Roy $F$. Weston Associates

2301 Research Blvd.

Rockville, MD 20850

ATTN: A. Metry

E. J. Ziegler

R. Roy

202 Materials Research Laboratory

University Park, PA 16802

F. K. Pittman

3508 Sagecrest Terrace

Ft. Worth, TX 76106

W. Hannum

DOE West Valley Demonstration Project office

West Valley, NY 14171

J. L. Knabenschuh

West Valley Nuclear Services

West Valley, NY 14171
No. of

Copies

ONSITE

6 DOE Richland Operations office

P. F. X. Dunigan, Jr.

0. J. Elgert

0. L. 01 son

H. E. Ransom

J. J. Schreiber

M. W. Shupe

10 Rockwell Hanford Operations

M. K. Altenhofen

H. Babad

R. A. Deju/R. J. Gimera

L. R. Fitch

R. N. Gurley/R. T. Wilde

M. J. Smith

D. A. Turner

B. A. Wolfe

T. Woods

J. W. Patterson

Westinghouse Hanford Company

A. G. Blasewitz/R. E. Lerch

55 Pacific Northwest Laboratory

W. F. Bonner

L. A. Bray

J. B. Brown

T. D. Chickalla

L. L. Clark

P. M. Daling

D. A. Dingee

H. K. Elder

E. A. Eschbach

V. F. Fitzpatrick

R. M. Fleischman

C. R. Hann

J. H. Jarrett/D. J. Bradley

D. E. Knowlton

M. R. Kreiter/J. M. Latkovitch 
No. of

Copies

ONSITE (contd)

Pacific Northwest Laboratory (contd)

D. E. Larson

R. C. Liikala/J. L. MCEl roy

R. F. McCal lum

R. W. Mckee (10)

G. B. Mellinger/H. H. Hollis

J. E. Mendel

J. E. Minor

R. E. Nightingale

D. R. Payson

A. M. Platt (2)

J. V. Robinson (2)

W. A. Ross

K. J. Schneider

D. J. Silviera

J. L. Swanson

G. L. Tingey/G. A. Jensen

D. S. Trent

R. P. Turcotte

H. H. Van Tuyl

M. K. White/G. W. McNair

L. E. Wiles

L. D. Williams

Technical Information (5)

Publishing Coordination (2) 